UNIVERSIDAD NACIONAL DE LA PLATA

FACULTAD DE PERIODISMO Y COMUNICACIÓN SOCIAL

Trabajo de tesis realizado para optar al título de Doctor en Comunicación

\title{
DISCRIMINACIÓN Y VIOLENCIA EN DOS BLOGS LGBTIQ
}

Autora: Magalí D. Pérez Riedel

Directora: Mg. Nancy Díaz Larrañaga

Noviembre de 2017 



\title{
DISCRIMINACIÓN Y VIOLENCIA EN DOS BLOGS LGBTIQ
}

\author{
Autora: Magalí D. Pérez Riedel
}

Directora: Mg. Nancy Díaz Larrañaga 



\section{AGRADECIMIENTOS}

Agradecemos a Nancy Díaz Larrañaga por su apoyo y sus enseñanzas desde hace más de cinco años. A los colegas del Instituto de Estudios Comunicacionales en Medios, Cultura y Poder "Aníbal Ford” de la Facultad de Periodismo de la Universidad Nacional de La Plata por sus contribuciones a lo largo del trabajo de tesis. A los docentes del Doctorado en Comunicación, sin quienes no hubiéramos podido encauzar nuestro proyecto de investigación.

A Pablo Scharagrodsky y a mis compañeros del proyecto de extensión universitaria "Prácticas de comunicación y educación por la desobediencia sexogenérica" de la Universidad Nacional de Quilmes por acompañarme en la labor del activismo cotidiano. A Gustavo Constantino por sus lecturas críticas de los avances de este escrito. Y a la Universidad Nacional de Quilmes, al Consejo de Investigaciones Científicas de la Provincia de Buenos Aires (CIC-BA) y al Consejo Nacional de Investigaciones Científicas y Técnicas (CONICET) por el otorgamiento de las becas y subsidios que permitieron financiar y hacer posible esta investigación.

Agradecemos también a nuestros entrevistados: a Verónica Dema y a Bruno Bimbi por dialogar con nosotros sobre sus blogs y por contribuir al desarrollo de esta tesis. A las y los integrantes de las organizaciones La Fulana, OTRANS La Plata, SIGLA, FALGBT y 100\% Diversidad y Derechos por abrirnos las puertas de sus casas y permitirnos trabajar en conjunto; por su tiempo, por su dedicación y por hacer posible que las personas LGBTIQ tengamos una vida mejor. $\mathrm{Y}$ especialmente extendemos nuestro agradecimiento a María Rachid, a la Dra. Dora Barrancos y a Paula Carri por sus apreciaciones sobre los debates aquí presentes.

A mis afectos, por acompañarme de forma incondicional durante este largo y arduo proceso de investigación. Sobre todo al Ing. Leonel Bracco, por su asistencia técnica y su aporte al desarrollo de la investigación social. 



\section{ÍNDICE}

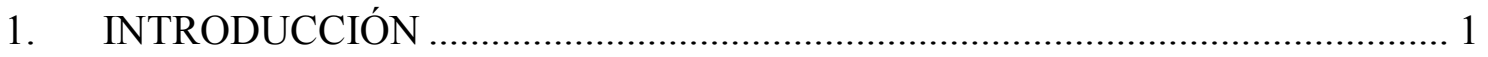

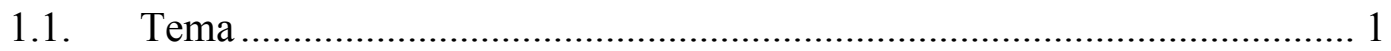

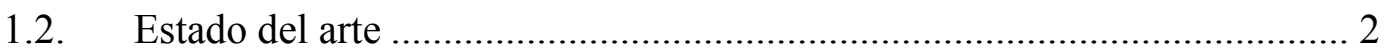

1.3. Construcción del objeto de estudio....................................................... 8

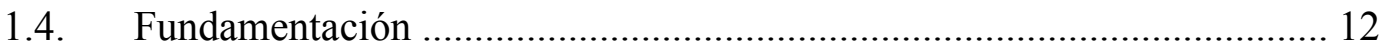

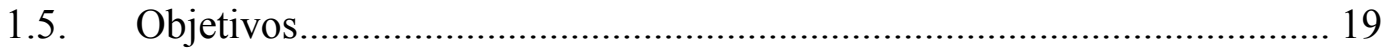

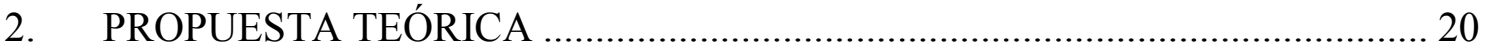

2.1. Estudios culturales, comunicación y cultura ........................................ 20

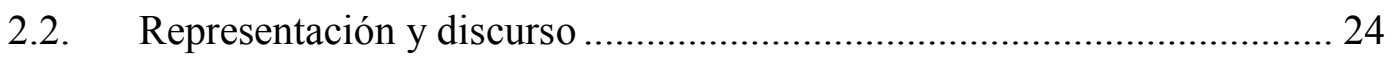

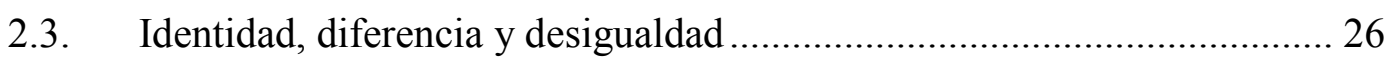

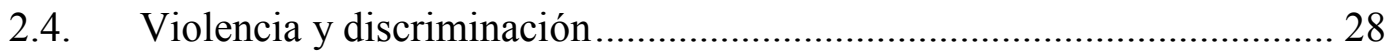

2.5. Géneros, sexualidades y feminismos.................................................... 34

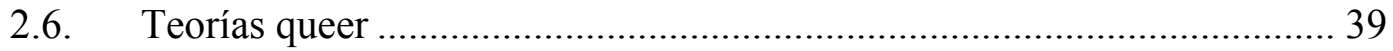

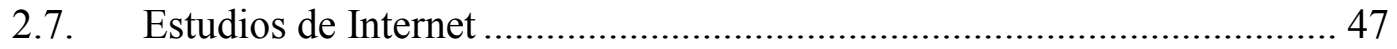

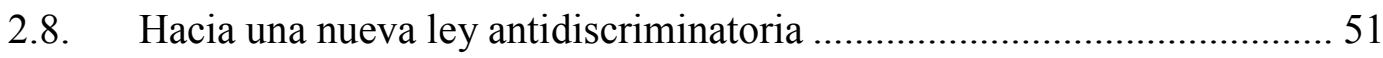

2.9. Historia de la homosexualidad y de la homofobia ............................... 67

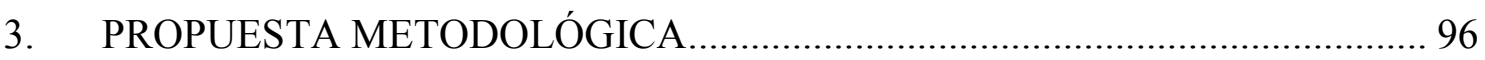

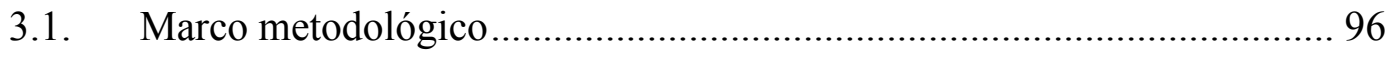

3.1.1. Los comentarios ........................................................................ 103

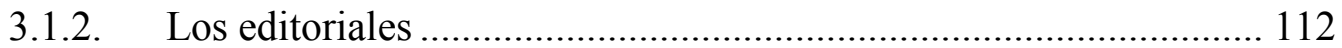

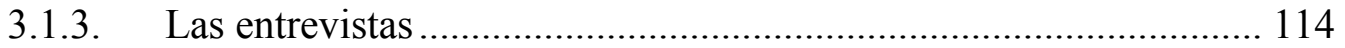

3.2. Consideraciones para el abordaje de las violencias.............................. 118

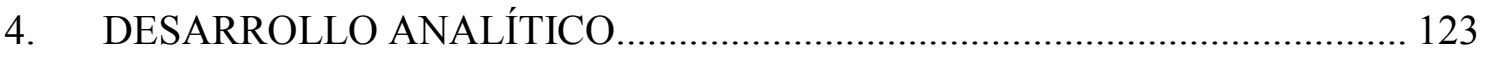

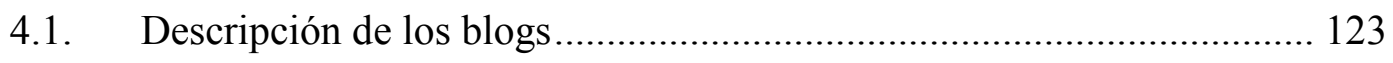

4.1.1. Boquitas pintadas ........................................................................ 127 
4.1.2.1Tod@s

4.2. "Que asco son!!!": representaciones discriminatorias y violentas contra las

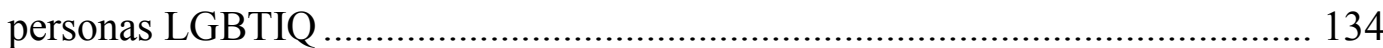

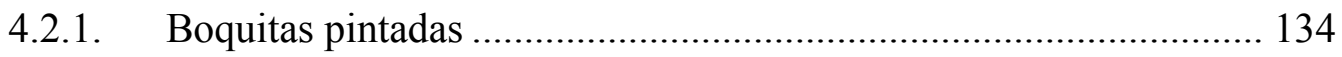

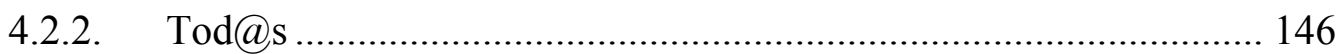

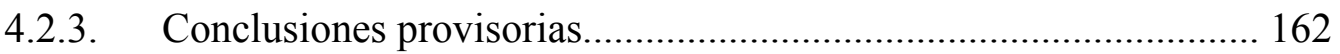

4.3. "Mudate a este milenio, marica reprimida": discursos resistentes ......... 172

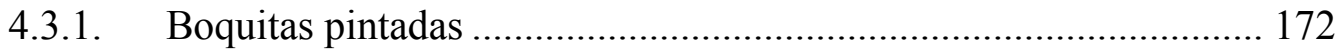

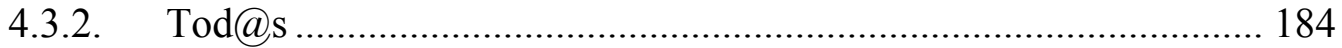

4.3.3. Conclusiones provisorias........................................................... 195

4.4. "En nombre de la discriminación se discrimina": los editoriales........... 202

4.4.1. Editoriales de La Nación.............................................................. 202

4.4.2. Editoriales de Clarín................................................................... 212

4.4.3. Conclusiones provisorias............................................................ 221

4.5. "Que haya debate": la moderación y la libertad de expresión................ 226

4.5.1. Boquitas pintadas .......................................................................... 226

4.5.1. Tod@s ...................................................................................... 233

4.5.2. Testimonios de referentes y activistas LGBTIQ .......................... 239

4.5.3. Conclusiones provisorias........................................................... 253

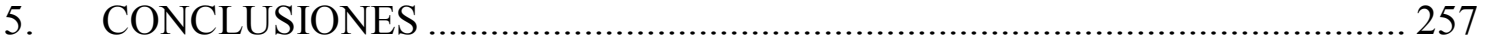

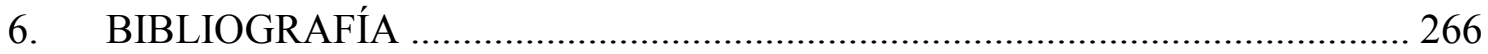




\section{INTRODUCCIÓN}

En este apartado se presentan el tema y el problema de investigación. En el estado del arte se repasan estudios e investigaciones en comunicación que abordan objetos de estudio tales como blogs, comunicación digital y géneros y sexualidades disidentes, entre otros. Luego se describe el proceso de construcción de nuestro objeto de estudio, se expone la fundamentación y se brinda información de contexto sobre el tema, con información sobre avances jurídicos en torno a los derechos de las personas LGBTIQ y cifras sobre denuncias por discriminación y crímenes por orientación sexual y expresión e identidad de género. Asimismo, se da cuenta de los proyectos y programas de investigación y extensión que trabajan con una perspectiva de género y diversidad sexual en la Universidad Nacional de Quilmes y en la Universidad Nacional de La Plata, instituciones en las que se gestó este trabajo. Por último, se exponen los objetivos generales y específicos de esta investigación.

\subsection{Tema}

Esta investigación trata sobre discriminación y violencia en dos blogs de temática de diversidad sexual. Aquí se analizan las representaciones discursivas discriminatorias y violentas sobre lesbianas, gays, bisexuales, personas trans, intersexuales y queers, entre otros (LGBTIQ) en los comentarios publicados entre 2012 y 2015 en Boquitas pintadas y Tod@s, y en los editoriales que hablan sobre este colectivo y que fueron publicados en los diarios Clarín y La Nación, responsables de esos sitios. 


\subsection{Estado del arte}

En este apartado comentamos brevemente algunos escritos que anteceden a esta investigación. Estos se relacionan con las temáticas que son transversales a nuestro trabajo, tales como comunicación en entornos virtuales, representaciones, identidades, lenguaje, discriminación, violencias, géneros y sexualidades. Es un listado suficientemente amplio para dar cuenta de los campos en los que se inscribe nuestro estudio y para evidenciar con quiénes dialoga, en tanto recientemente se ha configurado un área de interés en los estudios culturales que indaga acerca de las representaciones normativas y subversivas con respecto a los géneros y las sexualidades hegemónicas y disidentes desde una perspectiva queer. En este orden de cosas, nuestra preocupación por el análisis de comentarios publicados en los blogs y de los editoriales de dos diarios en particular se vincula con nuestro interés académico y personal por comprender las representaciones hegemónicas sobre las personas LGBTIQ $^{1}$ y las modalidades que adquiere la violencia en los entornos virtuales, siguiendo los antecedentes que exponemos a continuación.

En primer lugar, esta investigación retoma los aportes del libro de autoría propia, Género y diversidad sexual en el blog Boquitas pintadas (2014). Allí se relevaron los modos de participación en ese sitio para observar las características que adquiría la interacción mediada por computadoras. Circunscribimos dicho análisis al período abarcado entre octubre y noviembre de 2011 sobre un total de dieciocho artículos. En ellos encontramos un total de 3.085 intervenciones, donde 2.386 eran "Share" y "Me gusta" de Facebook y las restantes 699 eran comentarios escritos por un total de 275 usuarios. Algunos de estos comentarios contenían estereotipos peyorativos sobre los hombres y las mujeres homosexuales mientras que otros abogaban por un trato cortés e igualitario. Observamos entonces que coexistían formas solidarias de socialización e interacción con prácticas groseras que en su mayoría apuntaban a sostener las

\footnotetext{
${ }^{1}$ Las siglas LGBTIQ no son excluyentes ni exhaustivas, pero las utilizamos a lo largo de este trabajo con la intención de representar otros tipos de identidades y expresiones de género que escapan al binomio hombre/mujer y para hablar orientaciones sexoafectivas no heterosexuales. En otras palabras, las empleamos para referirnos a gays, bisexuales, lesbianas, travestis, transexuales, transgéneros, intersexuales y queers así como también a andróginos, asexuales, pansexuales y sujetos que dudan de su orientación sexual, agéneros, bigéneros, personas con género fluido, entre otros. No buscamos homogeneizar al colectivo ni imponer sentidos de pertenencia comunitarios donde quizás no los hubiere pero usamos estas siglas de ahora en más para servir únicamente a los propósitos discursivos de facilitar la comprensión del texto y de avanzar con el desarrollo de la investigación. Reconocemos la multiplicidad y la diversidad de este grupo de personas, grupo o sector que es más abarcativo de lo que indican las siglas y que incluye a un sinnúmero de prácticas, corporalidades, subjetividades, orientaciones sexoafectivas y expresiones e identidades genéricas disidentes.
} 
desigualdades sociales que someten a las personas LGBTIQ. También vimos que las jerarquías de género del mundo offline se trasladan, se resignifican y se perpetúan en la web.

Nuestras conclusiones coinciden con las esbozadas por Susan Herring en "Gender and power in on-line communication" (2003), donde presenta numerosas reflexiones sobre estudios acerca de la comunicación mediada por computadoras. Herring señala que algunos autores feministas teorizan sobre la posibilidad de “esconder" el género o de alternar su identidad en la web, sin olvidar su "yo". De este modo, uno decidiría cómo presentarse, pudiendo tener múltiples identidades en distintos contextos. Esto la llevó a pensar temporalmente que la Internet del siglo XXI podría salvar la brecha digital de género y ser una vía de socialización horizontal, hecho que, como afirma, está muy lejos de ser comprobado. Por ello indica que hay investigaciones recientes que demuestran que las dificultades de acceso que enfrentan las mujeres y las actitudes prototípicas suyas y de los hombres fuera de la virtualidad son transportadas a la web, donde persiste la disparidad de género al igual que en cualquier otro medio de comunicación.

La misma autora publicó en 2002 un paper titulado "Cyber violence: recognizing and resisting abuse in online environments". Allí conceptualiza a la violencia cibernética como una conducta que atenta contra el bienestar físico, emocional o psicológico de una persona o de grupos sociales, pero que a veces puede acarrear un componente de violencia fuera de Internet. Sugiere tipificaciones sobre los distintos modos de violencia virtual, ya sean ligados a prácticas de acoso o a otras de degradación, y entre sus ejemplos incluye casos de violencia de género. Esto es de vital importancia para nuestro estudio en tanto nos otorga un marco conceptual que facilitará la identificación y categorización de tipos posibles de prácticas violentas en las intervenciones que analizaremos. A su vez, los mecanismos que propone Herring para controlar y disminuir estos comportamientos hostiles pueden debatirse a la luz de las discusiones en torno al derecho a la comunicación y a la no discriminación en vistas a la construcción de una sociedad más justa e igualitaria.

En este sentido, Dafne Sabanes Plou (2013) observa en "Nuevos escenarios, viejas prácticas de dominación: la violencia contra las mujeres en la era digital" que los espacios digitales continúan con la lógica de poder de desigualdad patriarcal y se configuran como nuevos lugares de control de la vida de las mujeres y de avasallamiento de sus derechos. Así, redes sociales como Twitter o Facebook se usan 
para el acoso, la censura, el robo de información, la instigación al delito contra mujeres, el acecho, la difusión no consentida de fotos y videos íntimos reales o editados y la publicación de material humorístico sexista y misógino; a veces estas prácticas se materializan en agresiones físicas y sexuales. Sostiene que no existe un resguardo ante este panorama: los organismos públicos y la policía no toman en serio las denuncias que se hacen; tampoco hay legislaciones acordes ya que no se consideran los daños potenciales y reales de estas prácticas. Si bien su estudio se centra en las nuevas modalidades de la violencia contra las mujeres, sus aportes nos parecen relevantes dado que quizás esas violencias pueden ser ejercidas en la web en contra de otros sectores minorizados, tales como las personas LGBTIQ.

Encontramos otro antecedente a nuestro trabajo en "La violencia de género en los diarios Clarín y La Nación. De sentidos hegemónicos y usos políticos”, de Ana Soledad Gil (2014). En este estudio, la autora analiza los sentidos que se le dan a los términos "violencia de género" y "femicido" en las versiones digitales de Clarín y La Nación en el año 2013. Aborda estos diarios en particular bajo la hipótesis de que son medios de referencia en el país en la medida de que construyen sentidos desde un lugar privilegiado y legitimado en la sociedad. Adscribe a una perspectiva de género y recupera las herramientas del análisis del discurso, que le permiten observar que los artículos sostienen y legitiman los patrones socioculturales que conducen a la naturalización de la violencia contra las mujeres y el sexismo y el androcentrismo que las oprime. El interés de Gil por estos diarios y su análisis nos da un panorama general sobre las construcciones discursivas que estos diarios hacen respecto a las mujeres; más adelante procederemos de manera análoga con el estudio de los editoriales respecto a la diversidad sexual y los comentarios en los blogs que ya mencionamos.

Por otra parte, encontramos un artículo de Ernesto Meccia, "La carrera moral de Tommy. Un ensayo en torno a la transformación de la homosexualidad en categoría social y sus efectos en la subjetividad", extraído de Todo sexo es político. Estudios sobre sexualidades en Argentina (Pecheny, Figari y Jones, 2008). En este capítulo Meccia estudia la constitución del yo de Tommy, un hombre gay de 56 años que fue asesinado en su departamento en 2005. El sociólogo observa que la vida de Tommy fluctuó en la medida de que se pasó de un período de discriminación generalizada hacia una era donde los homosexuales gozan de más reconocimiento y aceptación social en las grandes urbes. Este sujeto, que inicialmente había aprendido a vivir con la discriminación, que la interiorizó y que la resistió, sintió que su identidad se 
desestabilizaba al ver que desaparecía aquella discriminación que lo había forjado ante un nuevo milenio que mercantilizaba la diversidad sexual, que la fetichizaba en los medios de comunicación y que creaba nuevos espacios de sociabilización. La vida de Tommy así nos sirve como excusa para comprender las características que toma hoy la discriminación en la vida cotidiana en contextos más o menos opresivos que no dejan de quitar vidas y afectar a los sobrevivientes.

En ese libro, Daniel Jones (2008) publica el capítulo "Estigmatización y discriminación a adolescentes varones homosexuales", donde expone los resultados de una investigación en la que entrevistó a hombres y mujeres adolescentes de la ciudad de Trelew, provincia de Chubut. Encuentra que existe un marcaje permanente que se sirve de distintas prácticas para delimitar las orientaciones sexuales y expresiones de género correctas, tales como los chistes, las risas, las burlas, los insultos gritados en la calle, las miradas, los señalamientos y las agresiones físicas. El autor cree que estos tipos de exclusión se vinculan con una reacción ante las transgresiones y con una sensación de amenaza a las jerarquías sexuales. Además, se legitima la discriminación y la estigmatización hacia los hombres homosexuales catalogados de afeminados, quienes generan prácticas de ocultamiento o de disimulo para evitar las sanciones. Dicho en otras palabras, las formas que toma la violencia operan como sostén de las sexualidades y géneros normativos; esta premisa atravesará nuestra investigación.

Martín Boy (2008), en "Significaciones y usos del espacio virtual en hombres gays de Buenos Aires", entrevista a homosexuales de clase media para indagar sobre los usos que hacen de las tecnologías digitales, específicamente de las salas de chat como espacios de negociación y tensión. Observa que se apropian de esta herramienta como un lugar de encuentro de seducción, que puede conducir a encuentros cara a cara. No obstante, aparecen algunos sesgos de discriminación hacia aquellos que no dominan los códigos del lenguaje que se emplean en esos entornos, por lo que se reproducen las desigualdades en función de atributos percibidos como negativos, ya sea por clase, lugar de residencia $\mathrm{u}$ origen, empleo o desempleo o rasgos ligados al afeminamiento, por ejemplo. El texto de Boy nos permite conocer qué usos y qué sentidos le dan estos sujetos sexuales a la comunicación mediada por computadoras y cómo allí se reproducen las discriminaciones y los prejuicios que transcurren por fuera. Claro que, como señala el autor, la diferencia entre lo virtual y lo no virtual es meramente analítica, ya que hoy es imposible comprender por separado esferas que se yuxtaponen entre sí. 
Luego, Aluminé Moreno entrevista a activistas y militantes LGBTIQ para conocer las políticas de visibilización del colectivo en el capítulo "La invisibilidad como injusticia. Estrategias del movimiento de la diversidad sexual" (2008). Allí observa que las Marchas del Orgullo que se realizan todos los años en contra de las formas de opresiones culturales y económicas no articulan los reclamos de todas las personas que se identifican como LGBTIQ. Estos realizan Contramarchas para marcar esta intersección con otros factores de diferenciación social y para denunciar el punto de vista privilegiado de algunos. La autora ve que existen múltiples maneras de construir y de visibilizar a este grupo como sujetos de derecho y que la mayoría coincide en la proyección de representaciones colectivas positivas en la esfera pública y política y en la necesidad de acabar con todo tipo de opresión, si bien no siempre están de acuerdo sobre cómo hacerlo o qué priorizar. Reconocer las diferencias intrínsecas al colectivo es crucial a la hora de avanzar con una investigación que busca estudiar las políticas editoriales que rigen dos blogs y dos diarios para representar a las personas LGBTIQ. Además nos recuerda sobre la imposibilidad de homogeneizar las reivindicaciones de este colectivo, en cuyo seno hay diferencias y contradicciones que no se deben pasar por alto.

Sebastián Settani (2013), por su parte, analiza las representaciones mediáticas televisivas sobre las Marchas del Orgullo de 2008 y 2009 en el artículo "Sexualidades politizadas y medios de comunicación: la Marcha del Orgullo LGBT de Buenos Aires". Allí identifica que los medios audiovisuales se reapropian del evento y lo resignifican por completo, despolitizándolo e invisibilizando las reivindicaciones del colectivo. Categoriza la labor periodística en tres tipos ideales; el primero es el periodismo aduanero, que coloca fronteras simbólicas y representa a la diversidad sexual en sus propios términos al mostrar lo que considera noticiable y al ocultar lo que decide esconder. Le sigue el periodismo explorador, que entrevista a los participantes pero no a los voceros de cada organización, y el periodismo de archivo, que sin acercarse a la marcha censura y sanciona la realización de las marchas. Para el autor, lo que hacen estos medios es acercar a los hogares la mirada estatal que hasta ese entonces excluía a homosexuales, bisexuales, lesbianas y personas trans para oficializar la marginación del diferente y continuar con su estereotipación y estigmatización. Por último, agrega que la visibilidad mediática que se les otorgó a estos actores no transmite sus demandas políticas sino que más bien contribuye a reforzar y legitimar las representaciones que habilitan su desigualdad. 
Asimismo, en el libro Estudios queer. Semióticas y politicas de la sexualidad (Forastelli y Olivera, 2012) encontramos el capítulo “Amanecer en la Era del Acuario. Walter Mercado, estrella del performance camp y queer", de Eliseo R. Colón Zayas. Allí el autor observa las diferentes características de la imagen del performer portorriqueño, su estilo, sus gestos y sus rasgos; esto es, su representación. Primero juega con la ambigüedad en los intersticios de lo masculino y lo femenino desde una estética camp para pasar a una imagen contestataria y un género sexual disidente o queer en el marco de los consumos mediáticos globalizados, influenciado por narraciones discursivas de la astrología y el sincretismo religioso. Este antecedente nos sirve como primera aproximación a los estudios queer en la medida de que muestra la fluidez de las identidades y la queerización de una figura mediática como es la de Mercado; es también una forma de performance que desafía los binarismos de género mediante la transgresión de las masculinidades y feminidades normativas. Pero nuestro estudio no indagará sobre las performatividades queer sino más bien sobre las representaciones atribuidas a todo el colectivo LGBTIQ.

En ese mismo libro, en "La transición democrática uruguaya: caricaturas homofóbicas y movimientos homosexuales", Diego Sempol (2012) analiza las viñetas cómicas publicadas en los diarios El dedo y en Guambia en la década de 1980 para observar que allí se representa a los varones homosexuales como sujetos invertidos, enfermos y feminizados frente a un modelo hegemónico de masculinidad, lo que reforzó un discurso machista y homofóbico para asegurar la dominación masculina, mantener la heteronormatividad y ridiculizar y estigmatizar al varón homosexual en un contexto de restauración democrática. Si bien nosotros no trabajaremos con el análisis de imágenes sino de discursos escritos, parece relevante recuperar un estudio en el que se ve cómo dos medios gráficos hegemónicos construyen la figura de los homosexuales y detentan estereotipos caricaturizados de los mismos, tal como podemos pensar que hacen los medios argentinos al abrir espacios virtuales de temática de diversidad sexual y permitir que allí se publiquen comentarios discriminatorios, por ejemplo.

Por otro lado, en los artículos "No rastro do prazer: problematizando prácticas sexuais, sociabilidades e violências”, de Fernando Pocahy y Manoela Carpendo (2012), y "Além das fronteiras da pele: masculinidades de mulheres em um bar do centro do Rio de Janeiro", de Andrea Lacombe (2012), se problematizan los sentidos sociales del cuerpo en la sociedad brasilera. En el primero se analizan las construcciones discursivas en torno a las prácticas sexuales que sostienen hombres con otros hombres en saunas y 
sex shops de alquiler de videos porno en Porto Alegre, mientras que en el segundo se trabaja sobre las representaciones de mujeres en su mayoría lesbianas que reinventan el significado de las categorías de lo femenino y masculino para invertir su orden en sus prácticas corporales y discursivas en un bar familiar brasilero. Y si bien nosotros no nos ocuparemos de los estudios de las corporalidades ni de las prácticas de apropiación de espacios de sociabilidad de homosexuales, sí nos interesan estos estudios por su análisis de las regulaciones de género entre heterosexuales y personas con sexualidades no normativas, y entre homosexuales; estos últimos también reproducen y sostienen formas de exclusión y de normalización, tal como vimos que ocurría en el blog Boquitas pintadas en 2011 (Pérez Riedel, 2014).

Por último, en el texto "Entre lo innombrable y lo enunciable: visibilidades y espacialidades LGBT en el cine argentino (1960-1991)", Guillermo Olivera (2012) encuentra que el cine anterior a la década del ochenta posee personajes secundarios o terciarios que son homosexuales, visibilizados a través de estereotipos relacionados con la criminalidad o la exclusión. En cambio, en los '90, aparecen películas donde el núcleo principal gira en torno a problemáticas o a personajes LGBTIQ. Ve que allí se refuerza una normatividad homosexual a la vez que se instaura la tecnología confesional del coming out como forma dominante y opresiva que produce afirmación $\mathrm{y}$ legitimación, sujeción identitaria, expulsión y exilio. Lo que ellas tienen en común es que renuncian a las performatividades camp y queer, ocultando las prácticas queer paródicas y subversivas que critican y trastocan el binarismo de género. Es decir, el régimen de visibilidad que antes permitía una representación estereotipada de las personas LGBTIQ pasó a permitirles entrar en la existencia pública pero sin mostrar la represión o exclusión que imponen las formas dominantes de ser y hacer. Esto último es crucial en nuestra investigación dado que nos compete entender esos modos de representación que marcan los límites de los regímenes de inteligibilidad y que violentan a quienes se sitúan en sus fronteras o se alejan de ellas.

\subsection{Construcción del objeto de estudio}

Los orígenes de esta tesis pueden encontrarse en textos que elaboré en forma de ensayos o trabajos prácticos en el marco de mi educación secundaria, motivada por sucesos propios de mi devenir adolescente y de amistades y personas a las que conocí 
en ese entonces. Escribía para entender problemáticas que no me eran del todo ajenas pero que parecían afectar por completo a algunos de los sujetos de mi entorno. Reconstruí esos casos de discriminación generalmente en textos narrativos que incluían a personajes LGBTIQ.

Claro que a medida que transcurrían los años me encontraba con distintos tipos de influencias vinculadas con el mundo del cine y de la televisión. Series argentinas como El tiempo no para y Los exitosos Pells, o extranjeras, como por ejemplo Looking, Modern family, Beautiful people, Six feet under, Transparent, Glee, Orange is the new black, As if, Queer as folk, Sense8, Will \& Grace, Sugar rush, Orphan black, The L Word y Rick and Steve, the happiest gay couple in all the world, marcaron algún tipo de hito. Lo mismo con bandas de música que cuestionaban la heteronorma o el binomio hombre/mujer: Placebo, Adicta, T.A.T.U. y Peter Punk.

Las películas son más: Dependencia sexual, But I'm a cheerleader, Mambo italiano, Breakfast with Scot, Kissing Jessica Stein, The trip, Milk, Boys don't cry, Red without blue, In and out, Tomboy, American Beauty, La jaula de las locas, Secreto en la montaña, I love you Phillip Morris, Dallas Buyers Club, La mala educación, Krámpack, Velvet Goldmine, Kinsey, Pride, XXY, Philadelphia, The kiss of the spider woman, La piel que habito, Beginners, The Danish girl y The imitation game, para nombrar algunas.

De este modo la curiosidad se apoderaba de mí: había un sistema de representaciones que ostentaba igualdad y visibilidad y que se oponía a otro que lo acallaba, que se servía de insultos para distanciarse de la posibilidad de ejercer algún tipo de comprensión sobre aquellos otros tildados de "diferentes" o "anormales". Me interesé entonces por conocer desde distintos ámbitos qué problemáticas afectaban a la comunidad LGBTIQ y cómo el lenguaje incidía en ellas. Así, podríamos decir que la tesis se gesta desde el momento en el que la diferencia se convierte en la norma y en el vector que marcaría la dirección de mis futuras intervenciones en mi campo de desarrollo académico y profesional.

Ya en mi formación de grado en la Licenciatura en Comunicación Social en la Universidad Nacional de Quilmes (UNQ), y como parte del ejercicio de mi acotada labor profesional como periodista, produje algunos textos acerca de sitios web gayfriendly o sobre pink marketing, además de trabajar sobre temáticas que poco tenían que ver con la diversidad sexual y de género. En lo que respecta a las investigaciones propias que anteceden a esta tesis, en principio, en 2010 integré un grupo de estudiantes 
con los que investigamos cómo concebían la sanción de la Ley de Matrimonio Igualitario nuestros colegas de la carrera. Aquel escrito permitió relevar que en su mayoría todos estaban a favor de la ley, a pesar de que uno prefería la figura de la Unión Civil.

Realicé un trabajo similar en una asignatura que cursé con el Dr. Alejandro Kaufman, a quien sorprendí con un ensayo crítico en el que analicé la construcción mediática acerca de las personas LGBT a partir de su espectacularización en los grandes medios de comunicación, su banalización y su reducción al absurdo gracias al fetiche del entretenimiento. Allí también evidencié la presencia de una forma hegemónica de sexismo cisheteronormativo que acompañaba a muchas de las prácticas de televisión abordadas en paralelo con la mercantilización de los símbolos representativos del colectivo como forma de otorgarles visibilidad ocultando sus reivindicaciones sociopolíticas.

Finalicé mi formación de grado en 2012 con la investigación a la que ya nos referimos sobre los modos de participación en el blog Boquitas pintadas en octubre y noviembre de 2011. En ese año inicié el Profesorado en Comunicación Social, también en la UNQ. Allí perseguí objetivos similares a los anteriores pero esta vez con énfasis en el campo de la educación. Por esa razón, en una actividad estudié los lineamientos curriculares y los manuales de Educación Sexual Integral emanados por el Ministerio de Educación; observé que estos refuerzan el binomio hombre/mujer, invisibilizan a las personas trans y a quienes no se amoldan a esos preceptos genéricos. Allí también se asocian a los hombres y mujeres homosexuales con la posición de víctimas de discriminación, a pesar de ser un avance significativo en un terreno muy poco explorado en los estudios e investigaciones sobre la educación y el currículum escolar.

Luego me preocupé por entender los modos en los que los materiales didácticos y el currículum escolar pueden sostener las asimetrías de género y la diferencia sexual y por ver de qué forma la biografía personal puede incidir en la modificación o reproducción de estos preceptos. Desde luego que esto guarda poca relación con las temáticas que abordo en mi tesis de posgrado, pero sí es relevante subrayar que esos tipos de relaciones asimétricas responden a una argamasa o a un entramado simbólico que las sustenta, las justifica y hasta las banaliza. E incluso pueden conducir a perpetrar actos violentos en contra de las personas, sean o no sean LGBTIQ.

Por otro lado, participé en el proyecto de extensión universitaria “¡De sexo sí se habla! Talleres de educación sexual y género para escuelas medias de la Zona Sur del 
GBA", dictando talleres en escuelas de educación media en primer lugar en el marco del proyecto y después como parte de la currícula de las asignaturas en las que me desempeñé como docente en el área de arte y de comunicación. Asimismo, colaboré brevemente en el Observatorio de Comunicación, Género y Diversidad con perspectiva de Derechos Humanos de la Universidad Nacional de La Plata (UNLP). Estos antecedentes son los que me permitieron impulsar y co-dirigir el proyecto de extensión "Prácticas de comunicación y educación por la desobediencia sexo-genérica" en la UNQ.

Pero cuando ingresé al Doctorado en Comunicación en la UNLP en 2012 presenté un plan de tesis que a lo largo de los años sufrió muchas modificaciones ya que no tenía muy en claro qué investigar: eran años de primavera para el colectivo LGBTIQ. Las recientes sanciones de las leyes conocidas como Ley de Matrimonio Igualitario y la Ley de Identidad de Género me hacían creer que ya no debía preocuparme más por las problemáticas que me inquietaban años atrás. Pero bastaba con encontrarse con insultos en la web o con escuchar groserías en la calle para notar lo equivocada que estaba.

Con todo, esta tesis dialoga con feministas e intelectuales preocupados por el cambio o la justicia social; con personas interesadas por promover políticas igualitarias que amplíen la participación de las mujeres y de los sectores minorizados en el desarrollo de la ciencia y la tecnología, y con sujetos preocupados por fomentar el ejercicio del derecho a la libertad de expresión y de abolir las formas de violencia y discriminación. Además, esta tesis entra en diálogo con la tradición de investigaciones realizadas en la Facultad de Periodismo y Comunicación Social de la UNLP en la medida de que se inscribe en la línea de los estudios culturales latinoamericanos y es allí donde intenta aportar reflexiones sobre el análisis de prácticas discursivas que detentan representaciones hegemónicas peyorativas sobre el colectivo LGBTIQ.

Pero también dialoga con campos de lo más diversos, tales como la sociolingüística, la sociología y la antropología. Cabe señalar que este estudio no pretende cerrarse al estricto campo de la comunicación y en todo caso demanda una mirada multifacética y transdisciplinar ya que observa de manera zigzagueante objetos empíricos que pueden ser propios de distintas áreas del saber. Las cuestiones de género, creemos, son transversales a todas ellas. Las investigaciones en comunicación no pueden ignorar la dimensión simbólica que construye y deconstruye géneros y sexualidades, dado que caso contrario invisibiliza o rechaza un entramado significante que abarca y cruza incluso a quienes investigan. 
Los ejes que se abordan en esta investigación se relacionan con el plano de las representaciones discursivas como espacios de lucha y de disputa para pensar en los sentidos hegemónicos y contrahagemónicos con respecto a los modos de ser, decir y hacer. Y trabajamos sobre el nivel de las identidades para entender los atributos que se le asignan al colectivo LGBTIQ para discriminarlos y violentarlos. Pero además la tesis nos coloca en el seno de las discusiones en torno a la libertad de expresión en Internet y al derecho a no ser discriminado, debates que parecen entrar en tensión permanentemente en la web. Por esto, creemos necesario conocer las manifestaciones de las violencias y de los discursos discriminatorios que se detentan a través de los entornos virtuales en relación con las políticas editoriales de los medios que las contienen y las actividades de regulación y de moderación de los espacios que habilitan la publicación de esos contenidos: los blogs.

\subsection{Fundamentación}

En las Ciencias Sociales y, específicamente, en el campo de la comunicación, es reciente la preocupación por los entornos virtuales en diálogo con las cuestiones de género. En la coyuntura argentina actual, se vuelve imperiosa la necesidad de abocarse a la producción de conocimientos en esta dirección, en tanto la emergencia de ciertas problemáticas contemporáneas demanda que con inmediatez se pueda dar respuestas para ayudar a comprender los fenómenos tanto macro como micro sociales. Es en este sentido que desarrollaremos un estudio con respecto a los modos de representación de la comunidad LGBTIQ porque el contexto sociopolítico argentino posterior a la sanción de la Ley de Matrimonio Igualitario (Ley No26.618/2010) y la Ley de Identidad de Género (Ley $\mathrm{N}^{\circ} 26.743 / 2012$ ) ha reconfigurado el panorama social y ha otorgado de mayor visibilidad a ese colectivo.

Observamos que a pesar de lo dicho anteriormente, cotidianamente se discrimina a las personas LGBTIQ y que se las denomina de formas despectivas mediante la atribución prejuiciosa de características que las invalida como personas. Vemos que existen mecanismos reguladores que estereotipan y fijan identidades, marginalizan sujetos y los constituyen como seres innombrables. También notamos que es posible contribuir a que se produzcan transformaciones para revertir las condiciones que 
conducen a su opresión y marginalización y para desmontar los dispositivos y las operaciones discriminatorias que convierten las diferencias en desigualdades.

En este sentido, esta investigación se inscribe en el área temática de “Comunicación, lenguaje y prácticas discursivas” del Doctorado en Comunicación de la Universidad Nacional de La Plata ya que parte de la idea de que en el lenguaje se anclan las asimetrías y desigualdades sociales. Nos situamos en el campo de la comunicación y en específico en línea con la tradición de los estudios culturales y de las teorías queer para analizar los discursos hegemónicos acerca de las personas LGBTIQ en una coyuntura en la que este colectivo reclama por su protección mediante la actualización de Ley Antidiscriminatoria argentina para prevenir y erradicar toda forma de discriminación por motivo de orientación sexoafectiva e identidad y expresión de género. Las principales contribuciones de nuestro trabajo radican sobre el reconocimiento de la urgencia por atender cuestiones vinculadas con sectores poblacionales minorizados y sobre la profundización sobre las discusiones acerca de la libertad de expresión y la regulación de la comunicación en Internet.

Avanzamos con la premisa de que el interés por las cuestiones de género es lo que convoca a la participación en los blogs Boquitas pintadas y Tod@s, que abordan temáticas de interés para las personas LGBTIQ, un grupo minoritario no sólo por su número sino además, claro está, por su dificultad de gozar con plenitud los derechos humanos que por años les habían sido negados; por esto, preferimos referirnos a ellos más bien como un grupo minorizado y vulnerabilizado. Asimismo, sostenemos que los blogs constituyen espacios institucionales más bien residuales en la medida de que abarcan tópicos que suelen no tratarse en los medios con mayor alcance. Y que a su vez la actividad de los moderadores de los blogs, que consiste en permitir la publicación de textos o su eliminación, conduce a hacer hablar al medio y a mostrar un posicionamiento ideológico que puede estar vinculado con su línea editorial.

De este modo, nuestro foco estará en las intervenciones peyorativas que recaen (no sin resistencias) sobre la comunidad LGBTIQ con el aval o con las restricciones que imponen los moderadores de Boquitas pintadas y Tod@s según las políticas editoriales, por lo que también analizaremos los editoriales publicados por La Nación y Clarín entre 2012 y 2015. Para tal fin, como ya dijimos, nuestro análisis estará circunscripto al estudio de los modos de construcción discursiva por parte de usuarios y de dos entornos virtuales en los que las personas pueden intervenir de diferentes maneras, motivo por lo 
cual nos interesamos por observar los discursos violentos y discriminatorios publicados en aquellos sitios para agredir a los sujetos LGBTIQ.

En suma, en esta investigación analizaremos cómo Clarín y La Nación, dos medios hegemónicos, representan a las personas LGBTIQ entre 2012 y 2015 a través de sus políticas editoriales en los editoriales y en los comentarios publicados en dos blogs de temática de diversidad sexual, Tod@s y Boquitas pintadas. El primer sitio pertenece a Todo Noticias del Grupo Clarín y su responsable es Bruno Bimbi. El segundo es del multimedio S.A. La Nación y está a cargo de Verónica Dema. Nuestras preguntas de investigación son: ¿Cómo se representa a las personas LGBTIQ en esos comentarios de los blogs y en los editoriales de Clarín y La Nación entre 2012 y 2015 ? Y, ¿por qué se publican comentarios groseros, discriminatorios y violentos a pesar de las condiciones de uso de cada blog y a pesar de la existencia de un moderador?

Abordamos los diarios La Nación y Clarín por ser los que mayor tirada tienen en papel en el país. Asimismo, trabajamos con Tod@s por tratarse de un espacio abierto por un activista por los derechos de las personas LGBTIQ y habilitado por uno de los multimedios más extensos del país. Por otro lado, seleccionamos el blog Boquitas pintadas con el interés de profundizar la investigación anterior. Inicialmente, llegamos a este blog tras toparnos con el editorial "Matrimonio y heterosexualidad" publicado el 5 de noviembre de 2009, donde La Nación en ese entonces se posicionaba en contra de la Ley de Matrimonio Igualitario.

Sabemos que la discriminación y la violencia son una constante en la vida de las personas LGBTIQ en mayor o menor medida. Buscamos indicios para probarlo en el informe que elaboró la Municipalidad de Quilmes, titulado Quilmes contra la discriminación, la xenofobia y el racismo (2011). Allí se indica que el 73\% de las personas encuestadas había sido víctima de casos de discriminación, especialmente en ámbitos laborales o destinados a la recreación y a la sociabilización. Este estudio mostró que principalmente se discriminaba a las mujeres y que las causas que hubieren provocado dichas prácticas se relacionaban con la nacionalidad de todos los censados y, en segundo y tercer lugar, con situaciones particulares y con su posición socioeconómica. Y luego, con su género y su orientación sexual. Más adelante, en 2014, el Instituto Nacional contra la Discriminación, la Xenofobia y el Racismo (INADI) publicó un informe posterior a la Ley de Matrimonio Igualitario y la de Identidad de Género. Allí se muestra que el $23 \%$ de los encuestados manifiesta su rechazo con respecto a hombres y mujeres lesbianas y que la cifra aumenta a un $40 \%$ si se trata sobre 
las personas trans. Por último, vemos que los números aumentan considerablemente si se habla de personas LGBTIQ que eran pobres, inmigrantes o portadores de alguna enfermedad estigmatizada.

Recientemente, la Comisión Interamericana de Derechos Humanos señaló que en 2014 se reportaron 594 crímenes motivados por la presunta orientación sexual de las víctimas. Agrega que escapan de este registro los casos que probablemente no fueron denunciados ya sea por temor a represalias o por el estigma que aún conlleva ser percibido como homosexual (CIDH, 2015b). Observamos que se extermina a las personas no solo por su orientación sexoafectiva sino también por su identidad y expresión de género, como ocurrió en la primera mitad del mes octubre de 2015 en Argentina: en solo dos semanas se asesinaron a tres mujeres trans, homicidios que se siguen cometiendo mientras desarrollamos este escrito. Se trata de crímenes de odio que se sustentan sobre discursos homobilesbobitransfóbicos y cisheteronormativos que han sido naturalizados e interiorizados por las personas que ejercen dichos atentados a la vulnerabilidad e integridad de los sujetos LGBTIQ.

Reconocemos que en el ámbito académico argentino es reciente el estudio de temáticas ligadas a los colectivos LGBTIQ en la medida de que la tradición de estudios gays y lésbicos en el país tiene una corta historia, pero aún más reciente es su incursión en investigaciones con una perspectiva queer. Para empezar, encontramos que existen diversos proyectos de investigación y extensión universitaria que desde las Ciencias Sociales abordan temáticas vinculadas con las mujeres en mayor medida y con la población LGBTIQ en menor medida tanto en el Departamento de Ciencias Sociales de la UNQ como en la Facultad de Humanidades y Ciencias de la Educación (FAHCE) y la de Periodismo y Comunicación Social (FPyCS) de la UNLP. Nótese que nos referíamos a estas instituciones por ser los espacios en los que se gesta y se realiza nuestra investigación.

En primer lugar, en la FPyCS encontramos centros e institutos de investigación que se encargan del estudio de problemáticas sociales en el país y en América Latina, como el caso del Instituto de Investigación en Comunicación, dirigido por el Dr. Carlos Giordano o el Instituto de Estudios Comunicacionales en Medios, Cultura y Poder “Aníbal Ford”, a cargo de la Dra. Saintout, donde se concluyó con la elaboración de esta tesis. En estos espacios se desarrollan investigaciones que abordan cuestiones vinculadas a los géneros o a las sexualidades disidentes, si bien su énfasis está puesto sobre el análisis, la reflexión y la producción de conocimiento acerca del entramado 
sociohistórico y cultural de los diversos sectores sociales. No obstante, iniciamos nuestra labor en el Instituto de Investigación en Comunicación, que posee distintas líneas de abordaje. Las que más interesaron para los fines prácticos de este escrito fueron las orientadas a la indagación teórica sobre corporalidades y estigmas, identidades y sujetos, lenguajes y discursos, donde situamos nuestro trabajo. Nuestra posterior incorporación al Instituto "Aníbal Ford” permitió profundizar en el análisis sobre el lugar actual de los medios de comunicación y la relación entre el Estado y la sociedad civil, lo que nos ayudó a reflexionar sobre nuestros objetos de estudio y sobre las problemáticas en cuestión.

Además, en esta facultad funcionan laboratorios y observatorios con distintos objetivos y enfoques. En este sentido, el Laboratorio de Comunicación y Género, que antes funcionaba como Centro de Comunicación y Género, adscribe a una perspectiva teórico-política orientada a denunciar la matriz excluyente enarbolada por la heterosexualidad normativa y obligatoria, que conduce a la subordinación de las mujeres y a la representación estereotipada de los sujetos. Este grupo de docentes, graduados y estudiantes de Comunicación Social trabajan tanto en investigación como en extensión universitaria bajo la dirección de la Dra. María Florencia Cremona. Al mismo tiempo funcionan como observatorio de medios para develar y denunciar las operaciones mediáticas mediante las cuales se refuerzan los roles y los estereotipos de género dominantes.

Por último, el Observatorio de Comunicación, Género y Diversidad con perspectiva de Derechos Humanos, a cargo de la doctoranda en Comunicación Claudia Vásquez Haro, se encuentra trabajando sobre el sector de mujeres trans migrantes, sus perspectivas laborales y sus historias de vida. Los integrantes de este espacio adscriben a una perspectiva amplia y performativa del género y de las sexualidades en la medida de que no solo se preocupan por la subordinación de las mujeres sino también por las desigualdades e injusticias que conducen a la opresión de las personas lesbianas, gays, bisexuales y trans y por las formas sociales que deslegitiman las reivindicaciones de esta comunidad y convierten la diversidad en diferencia y desigualdad.

En la FAHCE, nos encontramos con el Centro Interdisciplinario de Investigaciones en Género, dirigido por la Dra. María Luisa Femenías, que abarca al proyecto de investigación "Espectros, diálogos y referentes polémicos: Judith Butler fuera de sí" y que recupera los postulados teóricos del feminismo y de la teoría queer desde la filosofía. A Femenías también se la puede encontrar como integrante del 
proyecto "Violencia de sexo-género en la interseccionalidad de clase, etnicidad, generación y discapacidad, en territorios sociales y escolares" del Instituto de Investigaciones en Humanidades y Ciencias Sociales. Este equipo avanza con una mirada que pretende develar y visibilizar todas las formas de violencia, discriminación, exclusión y segregación que recaen sobre las personas ya sea por su etnia, raza, género, orientación sexual o discapacidad.

Asimismo, en esa facultad funciona el proyecto de investigación "La constitución histórica del campo de la cultura física y de la educación física. Actores, instituciones, discursos y políticas. Argentina (1901-1938)", que analiza los sentidos que se construyen en la educación física sobre los cuerpos y las sexualidades, tal como indica su director Pablo Scharagrodsky. A su vez, en el proyecto "Nuevas juventudes y educación: cuestiones de género, cuerpo y politicidad desde una perspectiva intercultural" se exploran los modos de sociabilidad y las disposiciones y políticas corporales generizadas de los jóvenes.

Por otro lado, en la UNQ encontramos el programa de investigación "Escuela, diferencia e inclusión", donde se aborda la dimensión de la inclusión/exclusión en relación con sistemas pedagógicos educativos como dispositivos de generización desde inicios de la modernidad hasta la actualidad. Se orienta a producir conocimientos en torno a la construcción de subjetividades y sentidos a través y por medio de los dispositivos escolares modernos, de su análisis y crítica, para desandar los instrumentos didáctico-pedagógicos y evaluativos de la modernidad en todos los niveles educativos. En el caso del currículum en particular se reconoce que ha configurado masculinidades y feminidades ya sea por medio de lineamientos ligados a la educación física como a los oficios, a los saberes y contenidos que se deben impartir a los estudiantes por el mero hecho de ser hombres o mujeres, diferencias que estaban bien marcada hacia fines del siglo XIX e inicios del siglo XX y que hoy intentan erradicarse a través de políticas educativas inclusivas.

El programa "Tecnologías digitales, educación y comunicación. Perspectivas discursivas, sociales y culturales" se centraba en el estudio de las problemáticas vinculadas con las tecnologías digitales con respecto a la educación, la política, la comunicación, los modos de sociabilidad, de identidad y de representación. Allí se abarcaron objetos de estudio diversos e intrínsecamente interrelacionados, tales como el fenómeno de la televisión digital abierta y las posibilidades de acceso y de democratización de la comunicación a raíz de la Ley de Servicios de Comunicación 
Audiovisual, los modos de interacción y de auto representación habilitados por los entornos virtuales en general y por las redes sociales en particular. Si bien aquí las cuestiones de género no son constitutivas del proyecto, sí formaron parte de algunas de las investigaciones desarrolladas por sus integrantes.

Asimismo, la UNQ cuenta con un Observatorio de Memoria, Género y Derechos Humanos que pertenece al Centro de Estudios "Emilio Mignone". En él se llevan adelante proyectos de investigación relacionados con la lucha contra la discriminación, la violencia y terrorismo de Estado y la memoria sobre acontecimientos del pasado reciente. Toman a la violencia como un acontecimiento productor de sentidos que a su vez está conformado por múltiples dimensiones que deben ser contempladas por igual, como la simbólica, la representacional, la cultural y la mediática, sin pasar por alto la violencia sexual perpetrada contra las mujeres junto con violaciones sistemáticas de los derechos humanos de las personas. Ello implica atender y problematizar las ideas de igualdad y de género que están detrás de las políticas latinoamericanas de reconocimiento y de justicia, memoria y reparación. A ello apuntaba el proyecto de investigación denominado "Modos sociales de la violencia en el presente y el pasado reciente: subjetividades y discursos testimoniales", a cargo del Dr. Alejandro Kaufman.

Por último, en el proyecto "Instituciones y sujetos del cuidado. Transformaciones actuales de las representaciones y prácticas en el ámbito de la salud, la educación y las familias", se avanzó sobre interrogantes en torno al cuerpo y a las subjetividades, las prácticas de cuidado de sí y del otro, las instituciones de salud, la educación, el juego y la familia. La dimensión de género se encuentra presente en el quehacer investigativo de esta formación así como en la de varios de sus integrantes, quienes también participan en grupos de extensión universitaria para acercar la universidad a la comunidad. Tal es el caso del proyecto de extensión multidisciplinar “¡De sexo sí se habla! Talleres de educación sexual y género para escuelas medias de la Zona Sur del GBA", que forma parte del programa de extensión PRAXIS - Programa de Acciones para la Inclusión Social de la UNQ. En ese equipo se diseñan y se ejecutan talleres de educación sexual con una perspectiva integral, mientras que el proyecto de extensión que co-dirigí con Pablo Scharagrodsky, denominado "Prácticas de comunicación y educación por una desobediencia sexo-genérica" (2016-2018), avanza sobre talleres de formación superior para la discusión y sensibilización sobre las problemáticas que atraviesan las personas LGBTIQ. 


\subsection{Objetivos}

En esta investigación nos proponemos analizar cómo los medios hegemónicos Clarín y La Nación representan a las personas LGBTIQ a través de sus políticas editoriales en sus editoriales y en los comentarios publicados entre 2012 y 2015 en dos blogs de temática de diversidad sexual, Tod@s y Boquitas pintadas.

Sus objetivos específicos son:

- Analizar las representaciones discriminatorias y violentas acerca de las personas LGBTIQ que aparecen en los comentarios publicados en Tod@s y en Boquitas pintadas entre 2012 y 2015 ;

- Examinar los discursos que resisten a dichas representaciones en los comentarios de los blogs en el período señalado;

- Reconstruir las representaciones discursivas sobre las personas LGBTIQ que aparecen en los editoriales de las versiones digitales de los diarios La Nación y Clarín entre 2012 y 2015 ;

- Caracterizar y comparar las actividades de los moderadores de Tod@s y Boquitas pintadas en torno a la eliminación o publicación de comentarios discriminatorios y violentos. 


\section{PROPUESTA TEÓRICA}

En esta sección se definen las palabras clave de esta investigación. Las conceptualizaciones emanan desde los estudios culturales latinoamericanos pero sitúan a esta investigación en la trama de discusiones vinculadas a los feminismos, al movimiento LGBTIQ y a los estudios de Internet. En paralelo avanzamos sobre los debates contemporáneos sobre la actualización de la ley antidiscriminatoria en Argentina para seguir con una reconstrucción de la historia de la homosexualidad y de la homofobia.

\subsection{Estudios culturales, comunicación y cultura}

Los estudios culturales responden a proyectos intelectuales y políticos de quienes los llevan a cabo; en líneas generales, se trata de un proyecto de intervención con voluntad política que toma a la cultura desde su relación con lo político de manera tal que se pueda llevar a cabo una intervención social, con conocimiento de los condicionamientos materiales y simbólicos con los que operan las prácticas sociales, incluyendo las propias del campo de lo académico.

Los estudios culturales se caracterizan por distintos elementos tales como los que se sintetizan en el siguiente apartado:

Los estudios culturales constituyen un proyecto intelectual y político que: 1) concibe la cultura-como-poder y el poder-como-cultura; 2) suponen un enfoque no reduccionista que se expresa en una actitud transdisciplinaria; 3) implican una vocación política que busca intervenir sobre el mundo; y 4) su encuadre es el contextualismo radical (con respecto a su forma de teorización, a las 
metodologías utilizadas, a su conceptualización de la política y a su propio proyecto) (Restrepo; 2011: 15)

Los estudios culturales indagan sobre procesos culturales en su contexto en la medida que "todo es cultura y la cultura lo es todo" (Richard, 2010: 60).

Los estudios culturales no son idénticos en todas las partes del mundo ni en todos los períodos históricos; de hecho, creer que la vertiente latinoamericana de los estudios culturales es un desprendimiento de la inglesa es un error común, tal como denuncia Eduardo Restrepo (2012) recordándonos al referente Jesús Martín Barbero. El último señala que en nuestra región se hacían estudios culturales mucho antes de que se les pusiera esta etiqueta, a pesar de que no haya aquí una producción editorial ni institutos que hoy en día se inscriban en este rubro (2010). No obstante, es importante reiterar que una no es una traducción ni una aplicación de la otra, sino que ambas son corrientes de pensamiento situadas cuyo común denominador es la preocupación por producir conocimientos que sean capaces de cuestionar las relaciones de poder existentes para cambiar el mundo (Grossberg, 2009).

Sin perjuicio de anterior, podemos rastrear el origen de los estudios culturales ingleses en 1964 en el Centro de Estudios Culturales Contemporáneos de la Escuela de Birmingham. Sin embargo, los primeros aportes de los autores que lo integraron y que hoy muchos consideran sus "padres fundadores" datan de fines de la década de 1950 y comienzos de la de 1960; hablamos de E. P. Thompson, Richard Hoggart, Raymond Williams y Stuart Hall. El último sostiene que:

Los estudios culturales empiezan realmente con el debate acerca de la naturaleza del cambio social y cultural en Gran Bretaña de la postguerra. Constituyen una tentativa de dar cuenta de la manifiesta ruptura de la cultura tradicional, especialmente las culturas tradicionales de clase; se sitúan en el registro del impacto de las nuevas formas de opulencia y la sociedad de consumo en la muy jerárquica y piramidal estructura de la sociedad británica (Hall, 2010: 18)

Según Pablo Alabarces (2002), los estudios culturales se distinguieron de otros campos intelectuales por los objetos y las preguntas que se realizaron; se preocuparon, por ejemplo, por estudiar las relaciones entre las culturas obreras en la vida cotidiana ante el surgimiento de la cultura de masas. Se aproximaron al marxismo para pensar a la 
cultura como un campo de lucha y de resistencia, tras lecturas y relecturas de los aportes de Althusser y de Gramsci. En América Latina, también se recuperó el concepto de hegemonía gramsciano y se atendió con énfasis al estudio de las culturas populares, especialmente tras el retorno a la democracia una vez finalizados los procesos dictatoriales latinoamericanos y con la emergencia de la globalización económica y la mundialización cultural.

En este sentido, Raymond Williams (2000) define a la hegemonía de la siguiente manera:

La hegemonía constituye todo un cuerpo de prácticas y expectativas en relación con la totalidad de la vida [...]. Es un vívido sistema de significados y valores fundamentales y constitutivos - que en la medida en que son experimentados como prácticas parecen confirmarse recíprocamente. [...] No es solamente el nivel superior articulado de la 'ideología' ni tampoco sus formas de control consideradas habitualmente como 'manipulación' o 'adoctrinamiento'. [...] Es un complejo efectivo de experiencias, relaciones y actividades que tiene límites y presiones específicas y cambiantes (2000: 131-136)

Este concepto es en gran medida transversal a todos los estudios culturales latinoamericanos contemporáneos ya que no solo atiende las operaciones que detenta la cultura dominante sino también a las fuerzas alternativas que esta produce y limita y que son las que se oponen a ella, la cuestionan y la amenazan.

Sin embargo, debe decirse que hoy pareciera ser que los estudios culturales son más una moda o un "lugar común" para muchos de los que estudian la cultura; se conserva el interés por los mismos objetos de estudio y el mismo eclecticismo teóricometodológico pero nos acercamos a un proceso de despolitización: se ha debilitado la comprensión por la dimensión político-económica estructural de los fenómenos culturales. Tal como indica Néstor García Canclini, esto puede resumirse con la palabra "estanflación", o estancamiento con inflación, devenida de las condiciones actuales de producción "empresarial” o ensayística y la proliferación globalizada de pequeños debates, que no dan lugar al surgimiento de nuevos conceptos ni hipótesis (1997).

Uno de los grandes aportes de los estudios culturales, además de su reflexión acerca del lugar político y situado de los investigadores, radica en su concepción particular acerca de la cultura, entendida como un proceso activo de construcción de sentidos en los que personas posicionadas en lugares diferentes disputan sobre su 
significación, si bien en su forma hegemónica la cultura se muestra como coherente y libre de ideología (Wright, 1998). En general, los estudios culturales pretenden romper y tomar distancia de las perspectivas que la asimilaban con las costumbres, creencias y hábitos del ser humano por su mera pertenencia a una sociedad, de aquellas que la ligaban a un pueblo y a un territorio particular; e incluso se alejaron de otras que asociaban a la cultura con algo que solo servía para legitimar políticas públicas y acciones sobre los "otros" (Grimson, 2011). Esas miradas, que responden a diferentes tradiciones y posicionamientos ideológico-políticos, no son suficientes a la hora de abarcar las distintas variables que entran en juego en la cultura tal como la entienden quienes adscriben a los estudios culturales.

En este sentido, Raymond Williams propone definirla como un "proceso social total" en el que circulan y se disputan sentidos socialmente construidos e históricamente transformados (Alabarces, 2002: 86). Y en el seno de la cultura acontecen procesos sociales de producción de sentidos a los que Williams define como "comunicación". Esta definición sin duda se diferencia de aquellas que conciben a la comunicación como una mera transmisión lineal de mensajes que serían enviados por un medio de comunicación masivo, y recibidos por una masa influenciable y pasiva. El autor critica esta teoría efectista y sostiene que lo que debe considerarse "es todo el ámbito común del discurso escrito o hablado" (1982: 57). Luego agrega que preguntarse por las formas de comunicación equivale a interrogar cómo se organizan las relaciones sociales y cómo son sus instituciones.

Pensar en el discurso como acción o práctica social nos permite avanzar con esta tesis desde la línea de investigación de los estudios culturales latinoamericanos, no para focalizarnos exclusivamente en las representaciones de las personas LGBTIQ pero sí para contemplar que los textos del corpus son parte de una red de relaciones en las que circulan e intentan imponerse sentidos y legitimar significados en un marco que condiciona a la vez que habilita su publicación; con esto último no nos referimos únicamente a los reglamentos y a las normas de uso de cada sitio sino más bien a las particularidades socioeconómicas y político-jurídicas que restringen o favorecen el acceso a la World Wide Web y que afectan al goce del derecho a la libertad de expresión. 


\subsection{Representación y discurso}

Podríamos sintetizar lo dicho hasta ahora con el párrafo que sigue:

Los estudios culturales se ocupan del papel de las prácticas culturales en la construcción de los contextos de la vida humana como configuraciones de poder, de cómo las relaciones de poder son estructuradas por las prácticas discursivas que constituyen el mundo vivido como humano. [...] Buscan entender no sólo las organizaciones de poder, sino también las posibilidades de supervivencia, lucha, resistencia y cambio. (Grossberg, 2009: 17)

Ahora bien, cuando hablamos de prácticas discursivas nos referimos a los textos escritos $\mathrm{u}$ orales que intervienen en una relación de interdependencia mutua en un contexto particular, incidiendo uno sobre el otro y viceversa. En este sentido, nos preocupamos por estudiar los editoriales de La Nación y Clarín y los comentarios publicados entre 2012 y 2015 en Boquitas pintadas y Tod@s en la medida que pensamos a los textos no como objetos aislados que debemos interpretar sino más bien como producciones y productos culturales que responden a especificidades estructurales internas y sociohistóricas y que poseen una intención y un grado relativo de determinación (Williams, 1997).

Uno de los "padres fundadores" de los estudios culturales, Stuart Hall, denuncia que el "giro lingüístico" constituye, como él dice, una "desviación necesaria" (1992: 59). Sostiene que con los aportes del trabajo estructuralista y semiótico avanzaron hacia el reconocimiento del lenguaje como parte de todas las investigaciones culturales y como fuente de significado; pasaron a entender las representaciones como sitios de poder y de regulación, a lo simbólico como fuente de identidad y a textualidad como lugar de representación y resistencia. Propone no olvidar estos aportes pero resalta que es indispensable recordar que lo discursivo está siempre implícito en la definición de cultura; por ello, se deben analizar las estructuras materiales y las configuraciones simbólicas de su contexto (1992).

Asimismo, Hall cree que "la representación es una parte esencial del proceso mediante el cual se produce el sentido y se intercambia entre los miembros de una cultura" (2010: 447). Agrega que: 
La representación es la producción de sentido a través del lenguaje. En la representación, sostienen los construccionistas, usamos signos, organizados en lenguajes de diferentes clases, a fin de comunicarnos significativamente con los otros. Los lenguajes pueden usar signos para simbolizar, estar en el lugar de, o referenciar objetos, personas y eventos en el llamado mundo 'real'. Pero pueden también referenciar cosas imaginarias y mundos de fantasía o ideas abstractas que no son de manera obvia parte de nuestro mundo material. No hay relación simple de reflejo, imitación o correspondencia uno a uno entre el lenguaje y el mundo real. El lenguaje no funciona como un espejo. El sentido es producido dentro del lenguaje, en y a través de varios sistemas representacionales que, por conveniencia, llamamos 'lenguajes'. El sentido es producido por la práctica, por el 'trabajo', de la representación. Es construido mediante la significación - es decir, por las prácticas que producen sentido (Hall, 2010: 457)

En ese aspecto, tanto él como nosotros creemos que el lenguaje construye la "realidad" a la vez que intenta representarla. Por consiguiente, el sentido es construido en y por el lenguaje. Esta mirada construccionista implica pensar que los sentidos no están en las cosas sino que son móviles y arbitrarios; son producidos y reproducidos como resultado de prácticas significantes.

Por otro lado, Hall avanza sobre los discursos como sistemas de representaciones y dice que están profundamente implicados en procesos de saber/poder. En este sentido, afirma que el poder de la representación consiste en asignar o clasificar; es decir, tiene un poder simbólico que contribuye a sostener las desigualdades, especialmente en aquellas sociedades donde se naturalizan estas asimetrías. El poder ya no funciona como explotación económica o coerción física sino que detenta una violencia simbólica que se sirve de regímenes de representación para elegir cómo nombrar al excluido; esto es, cómo excluirlo. Para tal fin, el poder se sirve de varios mecanismos tales como la estereotipación, al servicio del objetivo de reducir, esencializar, naturalizar y fijar la diferencia (2010).

Judith Butler (1990, 1993) agrega que en el lenguaje existen ficciones reguladoras que refuerzan y naturalizan los regímenes de poder vinculados al binomio hombre/mujer, que se presentan como los dos únicos géneros posibles, eliminando la posibilidad de utilizarlo para representar la multiplicidad de identidades que existen, ya sean genéricas, étnicas, de clase u otras. Estos constituyen sistemas de representación que enmascaran a lo masculino (blanco, europeo u occidental) como lo universal, 
mientras que lo femenino se presenta como la alteridad, como el "otro" que necesita ser nombrado o señalado de manera diferencial en el lenguaje. La autora subraya la importancia de salir de estos binomios y de escapar a la violencia reguladora, excluyente y violenta del lenguaje, que institucionaliza y delimita identidades, a la vez que obstaculiza la representación y la consecuente visibilización de las alteridades.

Por último, debemos resaltar que cada representación pone en circulación ciertos sentidos y significados que ocultan el componente histórico y conflictivo detrás de la disputa por nominar o representar a alguien. Quien configura una representación, quien decide sobre ella, es quien actúa sobre la cultura. Es tal como lo expresa Louis Marin: "Si la representación no sólo reproduce de hecho sino también de derecho las condiciones que hacen posible su reproducción, se comprenderá el interés del poder en apropiársela. Representación y poder son de la misma naturaleza” (2009: 138).

En suma, con el lenguaje y a través de él se conservan tradiciones, se deslegitiman las identidades autopercibidas de los sujetos y se excluye a esa otredad construida desde la hegemonía en línea con sistemas de representación autoritarios, totalizantes y violentos y con macroestructuras jurídicas y económicas que oprimen a diversos sectores de la sociedad. Por eso, creemos que desde los estudios culturales debemos entender la representación tanto en sus modos de representación, sus prácticas y sus sistemas representacionales. Esto nos obliga a observar las injusticias en las políticas y en los sistemas de representación, no para hablar por los silenciados sino para reconocer los espacios en los que entran en conflicto con otros sujetos en sus vidas cotidianas (García Canclini, 1997). Por eso, en el siguiente apartado, emprenderemos la tarea de abordar el concepto de identidad sin pasar por alto el de diferencia y el de desigualdad.

\subsection{Identidad, diferencia y desigualdad}

En principio, proponemos definir a la identidad en línea con los aportes de Eduardo Restrepo (2007), quien afirma que la identidad es una construcción social que se da en relación y a través de la diferencia entre un "yo" o "nosotros" y "otros". Esta marcación es procesual, situada y se sostiene o se diluye por medio de prácticas, ya sean discursivas o no. Las prácticas de diferenciación y marcación pueden conducir a procesos tales como la segregación del diferente y la dominación o coerción sobre 
aquel. Las identidades son múltiples, se superponen y hasta a veces se contradicen entre sí. Algunas son adquiridas y otras asignadas, por lo que pueden convertirse en un factor de resistencia, de empoderamiento o de sumisión. En la medida que las identidades son inestables, se vinculan con la posición de una persona como sujeto sujetado y con el proceso de producción de subjetividades, que ayudan a aceptar o rechazar las posiciones de sujeción.

Restrepo sugiere que a las identidades se le dé un tratamiento que no conduzca a pensarlas por la negativa o en los binarismos que caracteriza a la modernidad. Por el contrario, recomienda no estudiarlas como entidades fijas sino más bien como posiciones dinámicas que se dan en relación. Esto supone crear una estrategia metodológica para no imponer sentidos ni esencializar grupos para dejar que estos hablen. Esto también implica examinar las narrativas identitarias con las prácticas de las que son parte. Por último, cree que es indispensable "no perder de vista la singularidad, la relevancia de lo particular, de la diferencia, atentos de no caer en el riesgo de fabricar exotismos o comunitarismos forzados" (2007: 32) con el propósito de conservar el carácter plural, diverso y contradictorio de las articulaciones identitarias de una persona o grupo.

Por su parte, Lawrence Grossberg dice que la identidad surge a partir de la diferencia como efecto de poder. En este sentido, sostiene que la "articulación de la diferencia, por añadidura a la otredad, se convierte justamente en el sitio material del poder discursivo y es una lógica fundamental de las formaciones modernas de poder" (2003: 163). Por su parte, Alejandro Grimson agrega que la lógica de la diferencia cultural puede emplearse para subordinar y dominar a grupos subalternos o bien para reivindicar derechos colectivos propios (2011). No obstante, en el tratamiento de estas diferencias, se debe problematizar la desigual distribución de poder, las desigualdades socioeconómicas y las estructuras materiales y simbólicas de las culturas. Por ello, las políticas de reconocimiento deben ir de la mano de políticas que aspiren a una igualdad y justicia social y a una distribución igualitaria de los bienes. De este modo, propone reconocer la diversidad como condición humana, histórica y cambiante; además, recomienda pensar en la diversidad como un recurso político, para entender cómo opera el poder clasificatorio de una categoría hegemónica y así lograr socavarlo.

Sin embargo, esta tarea no es para nada sencilla, sobre todo en una coyuntura que promueve políticas de inclusión a la vez que reinventa sus mecanismos de exclusión y de desigualdad; tal es así que aún hoy se oprime a las minorías mediante la 
“espectacularización de las diferencias” (Delfino, 1997: 35). Por ejemplo, se les otorga una máxima visibilidad o se las ridiculiza mediante la exageración de estereotipos en los medios masivos de comunicación. Estos regímenes de representación deben ser analizados como operaciones de violencia simbólica en tanto contribuyen a reproducir la desigualdad. En este sentido, María Graciela Rodríguez indica que:

Si se señala el carácter co-productor y legitimador de la desigualdad de las representaciones, es porque las explicaciones sobre la desigualdad no se agotan en las instancias económicas, sino que deben articularse con las categorías y clasificaciones que la ordenan y legitiman. Dicho en otras palabras, la desigualdad tanto posee una base material que la organiza, como también es el resultado de una construcción colectiva que opera en el encuentro entre la vida cotidiana y los circuitos de producción cultural. La desigualdad, entonces, se reproduce persistentemente a través de las estructuras, pero también de la reproducción del significado que tanto las instituciones (y entre ellas los medios) como los sujetos le dan a la desigualdad. (2011:2)

Por último, Stuart Hall agrega que las identidades son construidas a través de la diferencia y dentro de la representación, a través de la construcción discursiva de un dentro y de un afuera del campo de lo representable (1996). Y si contemplamos que este autor considera relevante la intervención del feminismo en los estudios culturales es justamente por invitar a pensar las cuestiones de género y sexualidad para entender cómo opera el poder (Hall, 2010). En este orden de cosas, Nelly Richard propone un modelo de crítica cultural feminista con énfasis transdisciplinario para "acoger la dimensión ideológico-cultural de los conflictos de valor, significación, poder, representación e interpretación que acompañan las prácticas sociales y políticas de identidad, resistencia y oposición" (2009: 84). Y nosotros avanzamos en esta dirección.

\subsection{Violencia y discriminación}

Las nociones de diferencia y de desigualdad nos obligan a hablar de la violencia y de una de sus manifestaciones, la discriminación. El concepto de violencia es polisémico y puede definirse como un tipo de agresión física o bien como una amenaza a que se ejerza dicha agresión sobre nosotros, entre otras acepciones posibles (Williams, 1976: 324-325). Según Rita Segato (2010), la violencia física es solo una de las formas 
que toma la violencia como forma de ejercer control y dominación. Pero hay una forma mucho más sutil e invisible, que es aún más difícil de denunciar y de reconocer como tal, que ella rotula con el nombre violencia moral. Su definición es la siguiente:

La violencia moral es el más eficiente de los mecanismos de control social y de reproducción de las desigualdades. La coacción de orden psicológico se constituye en el horizonte constante de las escenas cotidianas de sociabilidad y es la principal forma de control y de opresión social en todos los casos de dominación (2010: 112-113; el subrayado es nuestro)

Observa que la violencia moral configura aquella argamasa que entreteje y estructura las relaciones sociales, a la vez que sostiene y naturaliza las desigualdades y jerarquías de género; por lo tanto, actúa sobre el imaginario de una sociedad, sobre la percepción de uno mismo, sobre los modos de presentación y representación y sobre los valores éticos y morales de una cultura. Y sobre todo, contribuye a la subordinación de las mujeres y de otros sectores minorizados. En este sentido, la continuidad de la moral tradicional descansa sobre la violencia rutinizada. Agrega que "la normalidad del sistema es una normalidad violenta, que depende de la desmoralización cotidiana de los minorizados" (2010: 119).

En su carácter difuso y omnipresente, la violencia moral adquiere múltiples formas, lo que la convierte en un método eficiente para la dominación de las mujeres y para la reproducción de las desigualdades de género. En la medida de que es socialmente aceptada, tanto por su capilaridad como por su invisibilidad, se convierte en un instrumento útil a la hora de alienar a las mujeres de sus derechos como personas. Algunas de sus manifestaciones son la humillación, la intimidación, la sospecha, la coacción moral, la ridiculización, la desvalorización personal, profesional, intelectual, moral, o de su imagen corporal, sumado a gestos, actitudes y miradas, sin necesariamente incurrir en agresiones verbales. Lo más llamativo es que, según la autora, los perpetradores suelen ser jefes, maridos, parejas, padres, colegas, médicos y hermanos; esto es, personas del círculo íntimo de las mujeres. Dice que este desprecio por lo femenino también oprime a los hombres homosexuales, que por ejemplo en Brasil son víctimas de una doble violencia moral: la sexista y la racista.

Segato insiste en que los procesos de violencia son estrategias de reproducción del sistema y que, como tales, actualizan los mecanismos que permiten su conservación con inercia e invisibilidad. Es por ello que se ancla en las costumbres y se convierte en 
un proceso que es automático, a diferencia de las formas de violencia axiomáticas que son fácilmente identificables y que se materializan en valores y discursos que califican o descalifican explícitamente a las personas en función de su color, entre otras cosas. Sostiene que es más fácil defenderse de la última dado su grado de explicitud, mientras que la primera se presenta como un tipo de discriminación de los más inocentes. Pero esta no es menos nociva que la agresión física, si bien es la más difícil de denunciar y de erradicar. Por eso la autora apuesta a la eficacia simbólica del Derecho para incidir paulatinamente sobre la transformación de la moral, las costumbres y los prejuicios de una sociedad

Por su parte, Pierre Bourdieu (2000) habla de la violencia simbólica, que es constitutiva de las relaciones de dominación masculina. La define como:

[Una] violencia amortiguada, insensible, e invisible para sus propias víctimas, que se ejerce esencialmente a través de los caminos puramente simbólicos de la comunicación y del conocimiento o, más exactamente, del desconocimiento, del reconocimiento o, en último término, del sentimiento. Esta relación social extraordinariamente común ofrece por tanto una ocasión privilegiada de entender la lógica de la dominación ejercida en nombre de un principio simbólico conocido y admitido tanto por el dominador como por el dominado, un idioma (o una manera de modularlo), un estilo de vida (o una manera de pensar, de hablar o de comportarse) y, más habitualmente, una característica distintiva, emblema o estigma (2010: 12)

La violencia simbólica, a su vez, permite que con facilidad se perpetúe el orden establecido como si fuese natural y neutro, con sus injusticias, sus relaciones de dominación y sus privilegios. El mejor ejemplo de este tipo de violencia es la dominación masculina, que subordina a lo femenino no solo en el espacio doméstico sino también en el Estado y la escuela, instituciones que favorecen la reproducción de la diferencia entre los sexos mediante una operación que la presenta como algo natural ocultando que es una construcción social arbitraria. Se trata en definitiva de una operación ideológica y que se instaura en la forma de un sentido común que se cree objetivo, universal y trascendental, que da sentido a las prácticas de dominación y sumisión y configura la percepción según los esquemas de la visión androcéntrica.

La dominación masculina, dice el autor, se ancla en la construcción simbólica de la diferencia sexual al imponer usos legítimos e ilegítimos sobre el cuerpo y 
especialmente sobre los órganos sexuales y al mostrar esta diferencia como una propiedad biológica cuando es, reiteramos, una propiedad arbitraria. Sobre ella se crean las divisiones de género y se instaura el acto sexual como una relación de dominación y los modelos de masculinidad viril dominante y de feminidad dócil o dominada. Se erigen valores éticos, cognitivos y estéticos que atraviesan a toda la esfera social. Se establecen categorías para denominar las prácticas sexuales, siendo la heterosexualidad un patrón universal de lo "normal". La primacía masculina se funda sobre la razón androcéntrica y sobre la división de estatus entre lo masculino y lo femenino. Pero precisa de su consenso y de su complicidad, actividades de las que se encargan las instituciones que tienen el monopolio sobre la legitimación de prácticas sexuales y de discursos sobre la sexualidad, como la Iglesia, el Estado y la escuela.

Al igual que Segato, Bourdieu cree que es posible erradicar la dominación masculina a través de una acción política que supere los dualismos de la diferencia sexual y que transforme radical y progresivamente el orden social. En el caso de los movimientos gay-lesbianos sostiene que con una política de la sexualidad podrán cuestionar los fundamentos de sus relaciones de dominación simbólica heterosexual, dominación que a veces sucede entre los mismos homosexuales. Dichas políticas deben tener el propósito de hacer frente a las categorías negativas que los estigmatizan y los oprimen, así como también deben acabar con su invisibilización en la esfera pública. Para hacerlo, deberán organizarse en torno a las categorías que son utilizadas en su contra; esto es, apropiarse afirmativamente del signo del estigma y convertirlo en su emblema para ganar visibilidad, reforzarse como colectivo, imponer categorías nuevas de percepción y apreciación y acabar con las divisiones que hicieron posible su congregación.

María Luisa Femenías retoma el concepto de violencia de las obras de Segato y Bourdieu y afirma que la violencia simbólica "aísla, segrega, recluye y genera marginalidades, divide, condena y hasta aniquila o extermina” (2007: 70). En este sentido, agrega que todo sistema de dominación implica necesariamente este tipo de violencia, que descalifica, niega, fragmenta e invisibiliza a los otros, a la vez que oculta estos mecanismos arbitrarios de poder. Esta dominación, que es relacional, se funda en ciertas jerarquías de estatus, que incluso crean estereotipos para justificarla. Define a los estereotipos como simplificaciones que reducen las características de un grupo o un individuo a ciertos rasgos o atributos que contribuyen de manera funcional al sistema de poder que los creó. Esto se asemeja a la definición ya citada de Stuart Hall (2010) o a la 
que esboza Mary Talbot (2003), quien entiende a los estereotipos como prácticas de representación discursiva de catalogación o de tipificación al servicio del mantenimiento de un orden social mediante la reducción, simplificación y naturalización de rasgos, reales o imaginarios, de un colectivo. Se trata, en definitiva, de estrategias de separación de lo normal/anormal y de segregación de los últimos.

Este tipo de dominación violenta, que, dijimos, no se sirve necesariamente de la coacción física, se ejerce en la forma de discursos institucionalizados que tienen una fuerza regulatoria. Según Femenías, operan como mecanismos de exclusión del campo de los "iguales" y de inferiorización de los "diferentes" con motivo de rasgos tales como el sexo, el color y la nacionalidad. Pero esta discriminación no tiene sustento en hechos biológicos sino que responden a construcciones sociales y posicionan a los diferentes en una posición de desigualdad. Sin embargo, al igual que Bourdieu, cree que las identidades colectivas no se forjan solo a partir de esta condición de desigualdad sino que pueden dar lugar a discursos alternativos y de resistencia como espacios de autoafirmación. Por eso, rechazar el concepto de identidad como concepto estabilizador, regulador y represivo permite pensar a las múltiples identificaciones o identidades sin esencia y así desestabilizarlas. Esta es la paradoja de las políticas feministas de la diferencia, y también de los movimientos LGBTIQ, que exaltan los valores positivos por los cuales se los colocó en un lugar de desigualdad a la vez que buscan el reconocimiento de sus derechos como personas y el pleno acceso a la igualdad económica y social. La autora resuelve la ecuación recuperando el término de "esencialismo estratégico", con el que invita a conservar los conceptos fuertes que permitieron una primera identificación (por ejemplo, "mujer") como si fuesen una esencia pero a sabiendas de que se trata de categorías ficcionales no universales. Con esta operación se pueden potenciar las diferencias en una búsqueda política por la emancipación y por una igualdad efectiva.

Desde la sociología de los márgenes, Sergio Tonkonoff advierte que la definición de violencia depende de su contexto socio-histórico. Relativiza la extensión del concepto en la medida de que varía de una época o de una cultura a otra según los sistemas de clasificaciones morales imperantes en un tiempo y espacio: lo violento será lo que se rechace colectivamente, lo que marque el límite o el borde de una cultura, de su sistema de reglas y de lo socialmente aceptable. Sostiene que: 
Si bien su definición es necesariamente contextual (o cultural), lo característico de la violencia reside en señalar precisamente el final de ese contexto. Es un significante de las fronteras del orden socio-simbólico, o más precisamente de la violación de alguna de sus fronteras últimas. Indica el pasaje al exterior radical del nosotros producido por las prohibiciones fundamentales. Por eso si se trata de una palabra es ésta una palabra límite, o mejor, un significante mítico - equivalente a otros significantes terribles como crimen y mal, e intercambiable por ellos (2014: 22)

Como dice el autor, la violencia es un concepto vacío; es también un objeto científico a construir y es "un significante incapaz de sentido articulado pero apto para condensar las ansiedades y los conflictos procedentes de los orígenes más diversos" (2014: 25). En este sentido, una sociedad instituye sus puntos de exclusión para distanciarse y repeler determinadas acciones, creencias, relaciones y objetos; esto es, aquello que no comprende pero necesita designar mientras produce condiciones para conservar su propia cohesión social. Por lo tanto, depende de sistemas de clasificación moral vigentes en un contexto dado. En consecuencia, la violencia no es física sino principalmente simbólica.

Por otra parte, Tonkonoff sitúa la violencia en el momento actual como aquello que limita entre las fronteras simbólicas de un conjunto social, aquello que aparece en la oposición entre el interior y exterior de una cultura, entre un yo y otro, distancia que es sitio de rivalidades. Pero el mito de la violencia es también una herramienta política al servicio de un intento de restaurar un orden simbólico. En tal caso, identificar o crear un enemigo, o catalogar un conflicto como violento, devuelve consistencia a una sociedad cuyos pilares se desmoronan en la posmodernidad. Esta mirada apocalíptica sitúa la reafirmación de un colectivo en el castigo de la violencia. La violencia, la transgresión de lo prohibido, cumple entonces una función relevante en la sociedad en vistas a la constitución y conservación de un orden particular. Indica que debemos entender que "lo que estará fundamentalmente prohibido, y quiénes serán los efectivamente castigados por su transgresión, es objeto de una lucha social interminable" (2014: 29).

Es, en suma, una forma de nombrar una transgresión del orden sociosimbólico. Por ello, Tonkonoff propone entender la violencia dentro de su contexto y en un marco de interpretación específico e invita a estudiarla desde distintas disciplinas de manera transversal, repudiando los estudios monolíticos que se hacen desde la criminología o la psicopatología, por ejemplo. Si bien adscribimos a la última afirmación, en tanto 
percibimos la necesidad de estudiar las violencias desde múltiples frentes, parece difícil aceptar sin reparos la sentencia de que la violencia demarca los límites de la cultura. Esto remite a intentos por instaurar fronteras donde lo que hay son superposiciones o yuxtaposiciones. Sin embargo, coincidimos con el autor en que la violencia responde a factores culturales y coyunturales. Por eso, es necesario observar las transgresiones ya que ellas pueden amenazar los valores de una sociedad, a la vez que se deben evidenciar los dispositivos por los cuales se resignifica y se nombra a la violencia en términos de criminalidad, de maldad o de enfermedad. En este caso, el sistema penal ocupa un lugar central a la hora de establecer castigos, de legitimar significados y de fijar las diferencias.

Hoy en día tenemos distintas categorías para nombrar los acontecimientos violentos y, como vimos, la discriminación es una de ellas. Se trata, sin ir más lejos, de la violencia moral axiomática que nombraba Segato, de la dominación y estigmatización del diferente a la que aludía Bourdieu, o de la desigualdad a la que se somete a los que se dejan fuera del espectro de lo "igual", como indicaban Femenías y Tonkonoff. Pero hay una definición más precisa aunque inacabada, la que figura en la Ley de Penalización de Actos Discriminatorios argentina (Ley Nacional N²3.592/1988), que entiende a la discriminación como aquel acto u omisión que impide, obstruye, restringe o menoscaba el ejercicio de los derechos y garantías constitucionales de las personas con motivo de su raza, sexo, religión, nacionalidad, ideología, clase, caracteres físicos y filiación política o gremial. La discriminación por orientación sexual, expresión e identidad de género no son abarcadas en esta ley; de allí se desprende que algunos movimientos LGBTIQ soliciten hoy su inclusión, así como también se entiende nuestro interés por incorporarlo en nuestro análisis en esta investigación. Sobre esto profundizaremos más adelante.

\subsection{Géneros, sexualidades y feminismos}

Según Elsa Dorlin (2009), las primeras definiciones acerca del sexo y del género provienen del campo de la medicina de mediados del siglo $\mathrm{XX}$ en un intento por intervenir los cuerpos ambiguos de hermafroditas o intersexuales en relación con el proceso de reasignación de sexo. Los sexos, que se creía que eran biológicos, estables y evidentes, permitieron dividir a las personas en "machos" y "hembras" e instalar una 
binariedad de identidades y roles sexuales que debían ser coherentes con ellos. También en la medicina se nombró a la bisexualidad por primera vez a finales del siglo XX y se decía que era una perversión. Para Dorlin, en 1895 aparece el término "heterosexual" para hablar de los instintos sexuales con finalidad procreativa, si bien otros autores colocan en esos años el surgimiento de la definición de homosexualidad y en 1920 el de su contrario. ${ }^{2}$ La diferencia entre los conceptos de sexo y género se marca con más claridad en la década de 1970, cuando desde la psicología se resalta el carácter social y cultural del género. Este concepto en ese entonces pasa a abarcar identidades, roles, valores, representaciones $\mathrm{y}$ atributos (masculinos o femeninos). El movimiento feminista de la época recupera el término para resaltar la arbitrariedad de los roles sexuales y de todo lo que incluye el género, pero conserva el de sexo como una realidad biológica ahistórica e inmutable: mientras problematiza el género, naturaliza al sexo y las relaciones sociales que derivan de él.

Eduardo Mattio (2012) ve que el trabajo feminista de los '70 y ' 80 recuperaba la premisa de Simone de Beauvior de que no se nace mujer sino que se llega a serlo. Las implicancias de esta frase llevaron a pensar al sexo como un atributo biológico pero al género como algo que no era natural, sino que era la construcción social del sexo. Con Gayle Rubin surgió la noción del sistema sexo-género como pretensión crítica y desestabilizadora de las relaciones entre los sexos, de las normas reguladoras y de las estructuras simbólicas y prácticas que prescribían las identidades sexuales. Por lo tanto, ser hombre o ser mujer era producto de roles contingentes socialmente asignados, que varían según el tiempo y el espacio. Pese a ello, se crearon nuevos tipos de jerarquías a partir de las ideas de que la diferencia sexual (macho/hembra) daba lugar al binarismo de género (masculino/femenino), que había una relación causal entre sexo, género y deseo y que esta coherencia se fundaba en una noción de deseo heterosexual. Además, como comenta Dorlin, en las décadas siguientes surgirían nuevos movimientos, como el feminismo negro, el feminismo lesbiano, el feminismo poscolonial y el posfeminismo, que denunciarían la matriz heterosexista y eurocéntrica del feminismo tradicional, que no pensaba en otras mujeres más que en las europeas, blancas, heterosexuales y de clase media o alta.

Algunos grupos posfeministas y los ligados a las políticas queer, de los que hablaremos más adelante, recuperaron y reivindicaron el concepto de sexualidad que

\footnotetext{
${ }^{2}$ Ver el apartado 2.9. Historia de la homosexualidad y de la homofobia.
} 
tematiza Michel Foucault en el primer volumen del libro Historia de la sexualidad. La voluntad del saber (1976). Allí el autor elabora una reconstrucción genealógica de los discursos que regulan la sexualidad a partir del estudio de las instituciones modernas, tales como el Estado, la Iglesia, el derecho y la medicina. Estos discursos no tienen una fuerza prohibitiva o represiva sino que por el contrario habilitan y promueven formas controladas, gestionadas y vigiladas de una sexualidad reglamentada por un régimen de poder-saber-placer que recae sobre los sujetos, comprendidos en su doble dimensión, tanto como sujetos como seres sujetados. Observa que la preocupación por la sexualidad siempre fue parte de la sociedad, en mayor o menor medida, y que en Occidente a partir del siglo XVIII había una incitación para hablar de la sexualidad, para nombrarla en sus múltiples variables, con el propósito de volverla económica y políticamente útil. Esta política de la sexualidad produjo diversos dispositivos institucionales y estrategias discursivas de la sexualidad, que se orientaron a establecer y a sostener sistemas clasificatorios para medir y evaluar y luego regular a toda la sociedad, si bien inicialmente habían surgido desde los sectores dominantes como una estrategia de control y dominio de sí.

Para Foucault, las tecnologías del sexo son unas de las tecnologías del poder más importantes en Occidente a partir del siglo XIX, indispensables sobre todo a lo largo del desarrollo del capitalismo en la medida de que requirió la inserción de cuerpos controlados en el sistema productivo junto con el ajuste de la natalidad. Pero las técnicas del biopoder, integradas por disciplinas anatomopolíticas del cuerpo humano y por una biopolítica de la población, actuaron en vistas al sustento de sí mismas no solo en el plano material sino también en el simbólico. Por ello, su énfasis cayó sobre la sexualidad infantil y sobre el cuerpo de las mujeres, la natalidad y el comportamiento sexual considerado perverso o anormal. El autor sostiene que esas técnicas “operaron también como factores de segregación y jerarquización sociales, incidiendo en las fuerzas respectivas de unos y otros, garantizando relaciones de dominación y efectos de hegemonía" (1976: 133). En otras palabras, instauran y legitiman relaciones de poder. La teoría de poder foucaultiana entiende que el poder se ejerce y circula en la sociedad en la medida de que es inherente a todas las relaciones sociales. Pero además existen tecnologías de poder que permiten que el sector dominante, de acuerdo a sus intereses políticos, logre controlar las vidas de las personas mediante disciplinas y regulaciones del cuerpo y de toda la población. Por lo tanto, el estudio de las sexualidades se 
convierte en una vía de acceso al estudio del ejercicio de poder entre hombres y mujeres, padres e hijos, adultos y jóvenes, entre otros.

Paul B. Preciado (2002) sigue profundizando las nociones de tecnologías productoras del género y de la sexualidad como dispositivo en el sentido que le atribuye Foucault. El filósofo propone hablar del género como una prótesis que es construida y orgánica a la vez, factible de ser intervenida. En este sentido, sostiene que el dildo, entendido como una tecnología sexual, puede suponer el final de aquel órgano en el que se ancla la diferencia sexual, el pene. Su uso estratégico puede devenir en una tecnología biopolítica que permita desenmascarar a la sexualidad como ideología y deconstruir y desnaturalizar la arbitraria lógica heterosexista detrás de la construcción de la diferencia sexo-genérica, aquella que reduce al cuerpo en órganos erógenos y que permite la dominación heterosexual. Con todo, se trata de burlar la biopolítica de los cuerpos al emplear tecnologías con usos que escapen de los controles impuestos por las tecnologías de la dominación, que intentan reinscribir a las personas en una $\mathrm{u}$ otra posición en la diferencia sexual y de género.

En este orden de cosas, Rosi Braidotti (1994) dice que a partir de la década de 1990 se desarrollaron las biotecnologías o tecnologías de la vida en la cual se han abarcado ya no solamente la sexualidad y la reproducción sino también otros instrumentos orientados al manejo calculado y racional de la vida en su totalidad. Así se crea un universo tecnológico que está guiado por el principio de prótesis donde el cuerpo humano es el primer fabricante de tecnologías para obtener una extensión orgánica de sí mediante la invención de herramientas, armas y artefactos y a través del lenguaje. Estas tecnologías apuntan a multiplicar las potencialidades del cuerpo, en los que la técnica y lo orgánico se complementan entre sí afectando a los sistemas de representación de la vida. De este modo, gana terreno el discurso del biopoder para dar lugar a un cambio en la representación de las formas culturales, legales, morales y emocionales. Donna Haraway (1995) también cree en la posibilidad de transformar esos dispositivos, por lo que propone el mito del cyborg, una criatura postgenérica utópica que trasgrede y desdibuja fronteras. Constituye una unidad mayor no unitaria en tanto fusiona al cuerpo humano con una máquina $\mathrm{u}$ ordenador, que abarca múltiples identidades "otras" y que lucha por mejores significados, formas de poder y de placer.

Por su parte, Teresa de Lauretis (1987) establece que el género es tanto una representación social como una representación de sí, resultante de diversas tecnologías tales como el cine o las disciplinas científicas, con lo que se distancia de los escritos 
feministas de antaño ya que cree que el énfasis puesto en lo sexual es una limitación para el desarrollo teórico. De este modo, invita a pensar el género como representación y como resultado de prácticas cotidianas e institucionalizadas: el género remite al conjunto de efectos producidos en los cuerpos, comportamientos y relaciones sociales dados por el despliegue de distintas tecnologías. Agrega que el género construye una relación entre dos entidades y funda un sistema de género, que establece un sistema de representaciones que atribuye clasificaciones, valores y posiciones a las personas en una sociedad. Es el producto y el proceso de una serie de tecnologías sociales, que tienen efectos constitutivos sobre hombres y mujeres y forma parte de la subjetividad de las personas.

En este orden de cosas, Judith Butler (1990, 1993, 2004) afirma que la inteligibilidad de los géneros no solo está dada por la continuidad y la coherencia entre sexo, género, deseo y prácticas sexuales sino también por la teatralización y la actuación del género en el marco de un sistema heteronormativo. Su teoría performativa del género le permite indicar que la materialización de la significación, o la significación hecha materia, deviene en efectos de poder formativos y constitutivos de la subjetividad humana. Ratifica que la matriz heterosexual otorga estabilidad a las posiciones generizadas asimétricas y desiguales a través de las variables socioeconómicas y de la dimensión simbólica que sostiene y refuerza los dualismos de género. Por ello invita a deshacer el género; esto es, los dualismos de género, con el propósito de trasformar aquellas performances históricas arbitrarias que se presentan como ahistóricas y naturales. De este modo, las prácticas corporales de subversión paródica de los géneros podrán alterar las normas que las sostienen.

Deconstruir el binomio hombre/mujer como par dicotómico ficcional es una propuesta válida en tanto este oprime a los cuerpos que no se ajustan a él. Sin embargo, el filósofo Eduardo Mattio (2012) habla acerca de la imposibilidad de prescindir del género como categoría analítica, no solo porque la identidad de género es para las personas trans parte de su reivindicación y de su lucha política, sino también porque, en sus palabras, "la noción de género ha proporcionado en las últimas décadas una herramienta emancipatoria tanto a las luchas de los movimientos de mujeres como a los colectivos LGBT" (2012: 86-87).

Si bien reconoce las tensiones y conflictos detrás de las apropiaciones feministas y transfeministas del concepto, empleadas con fines estratégicos diversos, Mattio sostiene que el concepto es relevante a la hora de transformar el imaginario 
androcéntrico, patriarcal y heteronormativo. Así, por ejemplo, se ha obtenido una total autonomía para modificar el propio cuerpo para adecuarlo a la identidad de género autopercibida con el reconocimiento estatal. Por eso, a la luz de estos logros recientes, concluye en que la emancipación de todo tipo de opresión no dependerá solamente del uso de una u otra palabra, pero que ante estas transformaciones en materia jurídico-legal es preferible conservarla para avanzar hacia la construcción de una sociedad justa, inclusiva y democrática, sin olvidar su articulación con otras variables. Las teorías queer profundizan este debate.

\subsection{Teorías queer}

El término queer sufre y ha sido objeto de numerosas críticas tanto en los países de habla inglesa como en América Latina. Es una palabra que puede traducirse como "raro", "torcido" o "maricón", que fue empleada de manera peyorativa en contra de las personas homosexuales pero que luego fue reapropiada de manera positiva por ellos mismos en países anglosajones como Estados Unidos. Sin embargo, hoy pocos se sienten interpelados por la palabra queer en el resto del mundo - incluso también en aquella región. Otros la ven como un paraguas que abarca a la comunidad LGBTIQ entera, a todo aquello que escapa de la matriz heterosexual; otros, en cambio, indican que el término queer remite a un rechazo a la identificación o adscripción a una categoría identitaria de sexo o de género.

Tamsin Spargo (2004) agrega que queer puede funcionar como un adjetivo, un verbo o un sustantivo y que nunca se equipara con lo normal, sino que se define en oposición a ello. Por eso, la teoría queer no describe una visión ortodoxa sino que abarca a una diversidad de prácticas y prioridades críticas, tales como análisis de las relaciones de poder dentro de la sexualidad, análisis de producciones literarias, fílmicas o musicales, críticas al sistema de sexo-género, estudios sobre las personas trans, prácticas S\&M y otros modos de transgresión. Es por ello que nosotros preferimos hablar de teorías queer en plural para indicar su multiplicidad y para no contribuir a su reducción a una forma unívoca y excluyente de interpretación y de reflexión.

La autora rastrea las raíces de la(s) teoría(s) queer en los movimientos de resistencia gay-lesbianos estadounidenses de la década de 1970, que se conjugaron con los movimientos de liberación de las mujeres para hacer frente a un sistema social que 
era la causa de su opresión. Pero hacia fines del período, la política gay/lesbiana pasó a reclamar la obtención de derechos y protección legal en el marco del orden existente. Las críticas a este asimilacionismo no tardaron en llegar; las personas bisexuales, trans y S\&M mostraron los límites de la inclusión de esas políticas identitarias. Además, el movimiento en los '80 se homogeneizó y parecieron primar los valores de los hombres y mujeres blancos de clase media. Las diferencias internas entre distintas facciones y entre grupos con diversas reivindicaciones mostraron la fragilidad del modelo comunitario, como también de la idea de que hay una identidad gay y lesbiana unificada.

Con la aparición del SIDA a mediados de 1980 y su posterior apropiación homofóbica, emergieron grupos radicales para resistir a estas representaciones intolerantes. Si bien nos extenderemos sobre la historia de la homosexualidad y de la homofobia más adelante, es pertinente indicar que en 1990 nace un grupo que empieza a configurar lo que hoy conocemos con el rótulo de políticas queer: el movimiento Queer Nation. Esta agrupación se apropió afirmativamente de un término de tinte peyorativo y exaltó la importancia de una diferencia que no quiere ser ni asimilada ni tolerada, sino que busca perturbar el status quo. Sin embargo, dice la autora, ya existían subculturas queer, como es el caso de las comunidades butch-fem de mitad de siglo, si bien no figuran en los relatos "oficiales" de los estudios gay-lésbicos.

Spargo señala que la teoría queer no es el sustento del movimiento queer. En realidad, por "teoría queer" se entiende a una serie de estudios que pertenecen a las humanidades, a la historia, a la filosofía, a los estudios literarios y a los estudios culturales. Estos estudios surgen de un modo distinto de comprender la identidad y el poder y se contraponen a lo normal, a la norma, ya sea hetero u homosexual. Esta teoría excéntrica o anormal recupera ideas del postestructuralismo, como la identidades inestables de Lacan, la de deconstrucción de Derrida y la de discurso, conocimiento y poder de Foucault. Agrega que no se puede situar el nacimiento de la teoría queer en un momento en particular, pero que empezó a cristalizarse en Estados Unidos hacia fines de 1980 en conferencias académicas sobre temas ligados a la homosexualidad.

Por último, indica que hoy la cultura y la teoría queer son objeto de las mismas críticas que se hicieron contra los postestructuralistas, ya sea por ignorar las realidades de opresión, por su rechazo de lo mundano o por fetichizar el discurso. Y para otros, lo queer no es más que una moda que perdió su tinte transgresor. Por eso, según Spargo, la teoría queer en el discurso académico se encuentra en medio de un doble movimiento. 
Dice que tiene que "oponerse al saber y producirlo, desafiar las normas pero mirar hacia el futuro posible conforme a una ortodoxia paradójica. Si lo queer se vuelve normal, respetable, si se convierte meramente en otra opción más, deja de ser queer" (2004: 81). Y si bien es cierto que han proliferado los textos que se autoatribuyen esta etiqueta, no por eso se los debe subestimar a menos que no conserven su actitud crítica y con eso contribuyan al sostenimiento de relaciones desiguales de poder.

Para Judith Butler (2004), la teoría queer adquiere un fuerte peso en el activismo antihomofóbico en tanto afirman que las señas identitarias no son un prerrequisito para la participación política. Agrega que:

La teoría queer se opone a aquellos que desean regular la identidad y establecer premisas epistemológicas para quienes reclaman cierto tipo de identidad, no busca tan solo expandir la comunidad de activismo antihomofóbico, sino más bien insistir en que la sexualidad no se resume fácilmente ni se unifica a través de la categorización [...] La tarea de todos estos movimientos consiste en distinguir entre las normas y convenciones que permiten a la gente respirar, desear, amar y vivir, y aquellas normas y convenciones que restringen o coartan las condiciones de vida (2004: 22-23)

Cuando habla de activismo antihomofóbico remite a los movimientos LGBTIQ que incluyen a las personas trans e intersex frente a un movimiento gay-lésbico que inicialmente no respaldó las reivindicaciones de los primeros. Pero también abarca a las personas queers en un colectivo tan heterogéneo y contradictorio. Este grupo se orienta a favor de una propia autodeterminación y de la defensa de sus derechos como seres humanos en vistas a combatir todas las formas de discriminación y violencia.

El concepto de performatividad o performance queer que Butler (1990, 1993, 1997, 2004) y Eve Sedgwick (1985, 1998, 1999) emplearon en distintos escritos las posicionaron como grandes referentes de las teorías queer en la medida de que llaman a burlar las fronteras del género y las sexualidades para dar lugar a prácticas significantes subversivas. Lo mismo con la apropiación que hizo el movimiento LGBTIQ de las teorías de Foucault, sobre todo con las que emanan de La historia de la sexualidad. La voluntad del saber (1976). Sin embargo, para Paul B. Preciado (2008), lo queer se ha normalizado. En parte rechaza este término por las siguientes razones: 
La palabra queer que sirvió durante algunos años en los países anglosajones y en Europa, a través de un ejercicio de traducción cultural, para nombrar estas luchas múltiples se ve ahora sometida a un proceso creciente de reificación y mercantilización (movimientos propios del régimen farmacopornográfico). Corremos el riesgo de hacer de la nominación queer una identidad generando nuevas exclusiones y eclipsando las condiciones específicas de la opresión de los cuerpos transexuales, transgénero, discapacitados o racializados. [...] No es que ya no podamos utilizar la palabra queer sino que esta ha perdido buena parte de su potencial subversivo y no puede hoy servir como denominador común para nombrar los procesos de proliferación de estrategias de resistencia a la normalización (2008: 239)

En su lugar, propone una política post-queer para crear nuevas prácticas de producción y reprogramación de la subjetividad, y no de su representación. Por eso, él opta por una política de la des-representación y del des-reconocimiento en pos de micropolíticas de experimentación y de producción tecnológica del género.

David Halperin (2000) coincide en que lo queer se ha normalizado pero llama a conservar el concepto a partir de la relectura de los aportes de Foucault. Sostiene que el tratamiento político que hizo este autor acerca de la economía de los discursos sexuales permite construir estrategias para confrontar y resistir a los discursos homofóbicos modernos. Y si bien afirma que queer es hoy una etiqueta de moda cargada de inconvenientes políticos y que su institucionalización académica no contribuye a su problematización, cree que tiene potencial si se la piensa como una identidad sin esencia, como un horizonte de posibilidad o como una oportunidad de transformación de sí. Se trata de una posición de resistencia, de un lugar que se define por su distancia y su diferencia de la norma. Es, en suma, una posición marginal que opera en oposición a lo normal, a lo legítimo y a lo dominante. Y es a su vez una construcción de nuevos valores y modos diferentes de vida. Por ello, las prácticas queer pueden designar un horizonte de posibilidades creativas, excéntricas y diversas que reestructuran la relación entre verdad, poder y deseo, por un lado, y entre cuerpo y placer por el otro. Esto incluye conductas sexuales, prácticas afectivas, construcciones de género, identidades eróticas, lógicas de representación y de enunciación y formas de producción de conocimiento y de constitución de sí, entre otras.

En este sentido, Joshua Gamson (2002) agrega que la sexualidad es clave en las teorías queer: una teoría social queer debe estar comprometida con el uso de la 
categoría de la sexualidad como un término ineludible para el análisis, la agitación y la reorganización en contra de las relaciones de desigualdad y de explotación. Por eso las teorías deben ir de la mano de las políticas queer, que se definen en gran parte en oposición al movimiento gay-lesbiano debido a su reciente normalización, como también se constituyen a sí mismas desde la diferencia. Este separatismo desafiante, como afirma, es una forma de "rebelarse contra la condición marginal como [de] disfrutarla" (2002: 151). Las políticas queer, entonces, corren el foco del género al de la sexualidad y se centran así en la utilidad y en la viabilidad política de las identidades sexuales, utilidad que es más bien operativa y estratégica y que se basa en una unidad identitaria cuestionable e inestable. Sin embargo, para Gamson, hoy las políticas queer enfrentan un desafío: mientras hacen tambalear los cimientos identitarios de las políticas de identidad, necesitan dotarse de una categoría identitaria como parte de su constitución como colectivo. Estas categorías, inestables y artificiales, operan como una manera de negociar una acción colectiva eficaz y a la vez permite disputar quiénes pertenecen al colectivo y cómo se lo denomina. De no resolver este dilema, no podrán alterar las bases de las instituciones que originan su exclusión.

Otros autores, como María Emilia Viteri, José Fernando Serrano y Salvador Vidal-Ortíz (2011) afirman que lo queer hoy "funciona como una forma de ubicarse en los debates sobre sexualidades y género y observar sus márgenes, normas y hegemonías" (2011: 47). Coinciden con Butler y Gamson en separar el término queer de gay o de homosexual debido a que remiten a cosas diferentes: desde su perspectiva la teoría queer surge en Estados Unidos como oposición a los gay and lesbian studies. Por otro lado, en América Latina, la teoría queer funciona como un marco desde el cual se formulan críticas a los sistemas heteronormativos para transgredirlos y desestabilizarlos desde un posicionamiento de pensamiento abyecto y fronterizo que se opone a toda forma de esencialismo identitario.

Agregan que la teoría queer latinoamericana surge en contra de la sexología y a sus estudios sobre la sexualidad, donde imprime sus ideas de normalidad, y se ve a la vez influenciado por el feminismo gracias a sus debates y discusiones en torno a las sexualidades, las teorías de género y de la diferencia sexual. Sin embargo, no tiene el mismo recorrido histórico que en la academia norteamericana porque aquí se han abordado temas vinculados a la diversidad sexual mientras se cuestionaba la categoría “gay”, por ejemplo, algo que en Estados Unidos sucedió de forma separada. Además, en América Latina se valorizó en una primera instancia la intersección de lo queer con la 
nacionalidad, raza, etnia y clase, algo que encontramos en las teorías estadounidenses en los años más recientes. Los autores concluyen en que lo queer siempre existió en América Latina incluso mucho antes de su conceptualización regional y dicen que ello "se dibuja y se desdibuja, cobra formas inesperadas que confrontan nociones lineales alrededor del género y las sexualidades, y pone de relieve un marco colonial con su historia de desigualdades varias y dolorosas ya conocidas" (2011: 58).

En coincidencia con expuesto anteriormente, José Javier Maristany (2008) agrega que:

No se trataría ya de pensar necesariamente en la versión latinoamericana de lo queer como una traducción o un vacío a llenar, sino de cartografiar modalidades de concebir las políticas de representación de las minorías, al norte y al sur, de modo que pudieran conectarse y/o desviarse a partir de coincidencias o divergencias a niveles arqueológicos (2008: 24)

Parece ser que, en América Latina, la palabra queer muestra los límites de la traducción cultural y obliga a sostener su uso anglosajón para hablar de la imposibilidad de encontrarle un equivalente lingüístico y para subrayar su "rareza" y su crítica a todo sistema de clasificación. Al hablar de teoría queer, a pesar de los acuerdos y disensos, debemos comprender no solo sus variables en distintos países sino también sus condiciones de producción y de inteligibilidad y sus formas de apropiación regional.

Por su parte, desde Argentina, Mabel Campagnoli (2008, 2013) sugiere usar el término "cuir", siguiendo a Preciado, para dar cuenta del desplazamiento geopolítico de centro a periferia, de norte a sur. Presenta un feminismo cuir o feminismo en cueros para resistir a la normalización de los cuerpos y las sexualidades, destruir los modelos binarios hombre/mujer y hetero/homosexual, desmontar la matriz heterosexual y permitir la invención de modos alternativos de producir lo social. Piensa a lo queer/cuir como un sitio político difuso que está relacionado con luchas políticas históricas locales en pos de la desarticulación de las formas de opresión, como el racismo, el clasismo y el heterosexismo. A la vez, advierte sobre la necesidad de no fijar una prioridad en la agenda política a priori y recuerda pensar que no existe un sujeto queer estable para no caer en tendencias homogeneizadoras.

Silvia Delfino y Flavio Rapisardi (2010) también presentan al movimiento queer como parte de un entramado más amplio de luchas históricas contra la marginación, la exclusión y la represión política, jurídica y policial, en contra de los edictos, códigos de 
faltas y contravenciones que criminalizan la sexualidad, las identidades no normativas y las acciones colectivas. En Argentina, en los '90 y en el nuevo milenio, la diferencia de clase, religión, etnia, edad, género y orientación sexual se convertía en desigualdad; se fetichizaba la diferencia a la vez que se ocultaba su persecución y se reproducían las condiciones socioeconómicas neoliberales de opresión, empobrecimiento y proscripción de los sectores subalternos, que perpetuaban los modelos represivos genocidas dictatoriales. Por eso lo queer aquí operó no tanto como atributo sino más bien como forma de acción y organización colectiva en articulación con otras luchas políticas para resistir contra todo tipo de discriminación y de asimilación.

A su vez, las teorías queer son una crítica a la heteronorma y una estrategia política contra las normas económicas y políticas estatales que sostienen la marginación. Para ello, proponen atacar las instituciones productoras de estigmas: los medios, la medicina, la educación y las políticas de salud, entre otros. Pero además invitan a repensar los modos de acción colectiva para no ver a la perspectiva queer como un proyecto individual ante la proliferación de carreras y estudios de género que fetichizan y promueven la profesionalización acrítica en esta área. Es en realidad una incitación a la creación de nuevos modos de organización en la búsqueda de una vida digna y en contra de la discriminación, el irrespeto cultural y la represión (Delfino, 2009). Respecto a ello, Jeffrey Weeks (2012) sugiere que las políticas queer así como los cuerpos de conocimientos que reciben ese nombre corren el riesgo de aproximarse a las ideologías políticas de derecha al reivindicar su rechazo a los posicionamientos asimilacionistas. No obstante, una postura superadora de esta dicotomía, y la que sostendremos a lo largo de nuestro escrito, es que el problema no debe ser la cuestión de la asimilación sino el ejercicio de una política igualitarista anti-discriminatoria que abogue por los derechos de las personas sin importar su orientación sexual ni su identidad o expresión de género, y que demande su reparación ante su vulneración.

Con todo, las teorías o estudios queer tienen una larga historia de derivaciones dispares en tanto se hicieron múltiples apropiaciones teóricas y prácticas de aquellos proyectos ubicuos antihomofóbicos y de crítica social. A veces detrás de las filas de los estudios culturales, quienes trabajan con las perspectivas queer buscan disolver las identidades sexuales fijas y las categorías binarias de la sexualidad y de género desde los márgenes (McKee Irwin, 2009). Las teorías queer son entonces teorías raras, invertidas, desviadas; son todo lo peyorativo y afirmativo que se indica cuando se dicen esas palabras. Son teorías incómodas y desestabilizantes, que subvierten lo establecido y 
que intentan burlar las normas. Son entonces teorías mutantes, periféricas, de sujetos y objetos marginales, para cuestionar todo aquello que se nombra o se dice que es normal. Son también una propuesta política de cambio y de transformación social en la búsqueda política por la justicia y la igualdad; son una denuncia de las regulaciones y reglamentos de género, aún naturalizados, y una visibilización de los sujetos excluidos, abyectos y disidentes. Son una problematización de los discursos hegemónicos; por lo tanto, cambiarán en la medida de que se modifique lo que se considere y se establezca como lo normal (Delfino, 2009).

Las sexualidades e identidades transgresoras fueron y son objeto de estudio de distintos campos de conocimiento, incluido el comunicacional. Así, siguiendo a Gust Yep (2003), el surgimiento tardío en Estados Unidos de la articulación entre estudios de comunicación y estudios gay-lésbicos y más adelante los estudios queer puede ubicarse en los '90, a seis décadas de la emergencia del campo de comunicación. Estos trabajos pueden separarse en cinco grandes áreas temáticas: a) las investigaciones sobre el movimiento gay-lésbico y las retóricas de su activismo; b) gays y lesbianas en los medios de comunicación hegemónicos y alternativos; c) sexualidad, HIV/SIDA y comunicación interpersonal; d) performatividad sexual y de las identidades de género; y e) lecturas y análisis críticos y queer de los medios.

El autor señala que en líneas generales los estudios de comunicación suelen abordar las identidades y sexualidades desobedientes como si fuesen estables y fijas. Además, normalizan y sostienen los binarismos de género (hombre/mujer, homo/heterosexualidad) y refuerzan la heterosexualidad hegemónica al naturalizarla y dejarla sin cuestionar. Recientemente, solo algunos académicos han empezado a atender críticamente la violencia que ejerce la heteronormatividad sobre hombres y mujeres dentro de los límites de la heteronorma, como a quienes están fuera de ella: las personas LGBTIQ y las que están en las intersecciones entre raza, clase, género y sexualidad. Estos sujetos son invisibilizados o bien son seres construidos como "otredad", así marginalizados y consecuentemente sometidos simbólicamente, discursivamente, físicamente, psicológicamente y materialmente a esta forma de regulación y control social comúnmente denominada "heterosexualidad". 3

\footnotetext{
${ }^{3}$ Yep observa que en nombre de la normalización se ejercen cuatro tipos de violencias. La primera es interior e individual, semejante a la homofobia internalizada; una exterior e individual, que se traduce en la homofobia externalizada y cuya máxima expresión son los crímenes de odio. Le sigue una violencia interior colectiva, que se sitúa en el marco de lo discursivo; y, en cuarto lugar, una violencia exterior y
} 
Con interés por subvertir este orden simbólico opresor, los investigadores en comunicación deben actuar de manera tal que se comprendan los daños cognitivos y afectivos que genera la heteronormatividad sobre las personas queer en un nivel macro y microsocial, sin borrar las identidades, prácticas, discursos y experiencias de quienes desestabilizan los límites morales y las jerarquías políticas de la normalización. Dicho esto, nos encaminamos a sostener un posicionamiento feminista y queer en relación con los estudios de Internet, sobre lo que nos extendemos en la sección que sigue.

\subsection{Estudios de Internet}

Siguiendo a Klaus Bruhn Jensen y Rasmus Helles (2010), consideramos a Internet como una infraestructura comunicacional global y como una esfera pública, que posibilita la distribución de procesos comunicativos sincrónicos y asincrónicos de unoa-uno, uno-a-muchos y muchos-a-muchos. Su alcance global se presenta como más inclusivo y participativo, si bien ello no es garantía de la democratización de su acceso. Jensen (2011) agrega que en Internet se articulan y se negocian sentidos, representaciones y acciones de co-construcción de la realidad social, lo que obliga a distinguir a Internet de otros medios en tanto es una estructura informacionalcomunicacional y a la vez es un foro cultural donde se enmarca la acción social. Esto presenta nuevas complejidades y problemáticas metodológicas en torno a la disponibilidad, accesibilidad y performatividad en las redes. Pero también, como señala el autor, debe reconocerse que Internet opera tanto como herramienta como objeto de estudio y que envuelve a los estudios de ella en una doble hermenéutica que involucra a la forma y al contenido, al modo en que los sujetos interactúan con otros usuarios, con sus comunidades imaginadas y con organizaciones y con la plataforma con la que interactúan y a la que pueden reprogramar o transformar; aquí radicaría el valor de indagar sobre los usos para pensar en la posibilidad de hacer algo distinto con los medios y de contribuir en la reconfiguración del espacio digital presente y futuro.

Tal como señalan Charles Ess y Mia Consalvo (2011), los estudios de Internet tienen una historia reciente: su inicio se puede situar en la década de los noventa en torno a la explosión del acceso digital. Anteriormente se realizaban investigaciones sobre la comunicación mediada por computadoras y sobre la comunicación en red.

colectiva, cuyo anclaje institucional hace que la opresión heteronormativa y patriarcal se vuelva más severa, compleja, variable, ubicua, jerárquica y duradera. 
Actualmente los estudios de Internet se constituyen como un campo más institucionalizado que posee objetos específicos, que no necesariamente excluyen la posibilidad de contar con una mirada interdisciplinar ni con tomar de prestado técnicas y métodos de otras áreas. Temas de interés son entonces las dimensiones culturalmente variables como las prácticas, valores, creencias y normas, así como las diversas formas de interacción a través de Internet. También se ha incorporado al análisis una amplia gama de elementos, ya sea imágenes, gráficos, videos, sonidos y juegos, lo que se distancia de los estudios iniciales que solo se centraban en los textos escritos. Por otra parte, ya se superaron las dualidades que llevaban a separar lo online de lo offline y a aislar al cuerpo de los intercambios virtuales. Los estudios de Internet hoy están atentos a las estructuras de poder y a las hegemonías culturales que circulan en las redes, lo que conduce a derribar las ideas de que hablamos de un espacio democrático libre de relaciones de poder $\mathrm{y}$, en consecuencia, de conflictos. Los autores concluyen en la necesidad de contar con una mirada crítica y reflexiva sobre el impacto y la significación de las posibilidades de comunicación e interacción que provee Internet en nuestras vidas cotidianas para pensar a los sujetos no solo como usuarios $\mathrm{y}$ consumidores sino más bien como seres humanos y, sobre todo, como ciudadanos.

Las tendencias de los estudios sociales sobre Internet en relación con la comunicación y la web dan cuenta de ramificaciones y posibilidades distintas para el desarrollo de la investigación hoy. Ronald Rice y Ryan Fuller (2013) relevaron 315 artículos académicos publicados entre 2000 y 2009 en 46 journals de comunicación y luego los agruparon en seis grandes áreas de interés:

- Relaciones sociales (89 publicaciones): sus tópicos centrales son las comunidades, los las identificaciones con grupos virtuales, la construcción de la identidad individual y colectiva, la gestión de los vínculos sociales, los cambios en las formas de interacción y de sociabilidad, el capital social y el análisis de las redes sociales.

- Implicancias del medio, usos y maneras de entenderlo (75 artículos): entre los temas que abordan, se nombra a la cuestión de la credibilidad y de la confianza cibernética, la difusión, apropiación y/o rechazo de las innovaciones, los efectos del medio, los usos y las gratificaciones, los cambios en los modos de sociabilidad y los usos y comportamientos posiblemente dañinos de Internet. 
- Participación (53 artículos): algunos de sus temas incluyen el compromiso cívico o ciudadano, la acción política, la participación democrática en el espacio público y la participación colaborativa por parte de los usuarios.

- Sobre la sociedad (47 textos): en líneas generales, incluyen las transformaciones en las fronteras de las dimensiones sociales, las diferencias culturales, la brecha digital, la privacidad y las políticas económicas y sociales sobre las tecnologías de la información y de la comunicación.

- Atributos del medio (35 artículos): se centran en las características de la interactividad en las redes y en la adaptación de los géneros mediáticos a Internet.

- Marcos teóricos (16 publicaciones): entre ellos, se nombran a las posturas críticas con respecto a modelos teóricos previos, también a los nuevos modelos teóricos integrados y a las producciones de revisión teórica.

Los autores identifican que desde 2005 hubo un crecimiento en las publicaciones sobre las modalidades de participación y de interacción en la red, hecho que estuvo ligado con el incremento en el acceso a Internet a nivel mundial y con el advenimiento de la Web 2.0. Lo mismo ocurre en líneas generales en el resto de las Ciencias Sociales. Por último, señalan que todos estos temas pueden abordarse desde distintas perspectivas teóricas y que pueden solaparse o complementarse entre sí, tal como está sucediendo en la actualidad.

Algunas de estas perspectivas emanan de los estudios feministas y queer. Janne Bromseth y Jenny Sundén (2011) historizan los procesos ligados al desarrollo científico de teorías que abordan los géneros y las sexualidades en relación con las tecnologías digitales y el ciberespacio. Muestran que inicialmente hubo una tendencia a imaginar la matrix desde una perspectiva distópica y pesimista, que luego dio paso a una mirada más utópica y liberadora sobre Internet. Varios ejes se configuran como el denominador común de muchos de estos estudios: el cuerpo, la representación del género, la diferencia sexual, los usos de las tecnologías y las prácticas que tienen lugar en la web. Las autoras agregan que los estudios sobre las mujeres, los estudios de género, las teorías feministas, el feminismo poscolonial y las teorías queer colaboraron con la profundización de los debates en torno a Internet a partir del cuestionamiento y de la transformación de las nociones de poder, de identidad y de sujeto, sin pasar por alto las concepciones sobre los géneros y las sexualidades. Este conjunto de producciones 
teóricas ayudó a desafiar la idea de horizontalidad en la red abriendo discusiones sobre la posibilidad múltiple o limitada de esconder, de transformar o de actuar (performar) la identidad y el género, de negociar los límites de las matrices de inteligibilidad binarias y heterosexuales que se transpolan a las redes y de visualizar las tramas de poder que cruzan a las comunidades virtuales y que generan nuevos mecanismos de construcción de la mismidad y de la otredad, junto con nuevas formas de solidaridad, de normalización, de opresión y de resistencia. Los estudios de Internet deben profundizar sobre el análisis de estos asuntos, a la vez que no pueden ignorar su intersección con otras categorías que están intrínsecamente entrelazadas con las estructuras de poder, como son las categorías de raza y (dis)capacidad. Con todo, concluyen en que los estudios de Internet deben fortalecer su vínculo con las teorías feministas y queer con el fin de explicitar cómo opera la relación entre género y sexualidad. Asimismo, debe abrirse el campo a otras intervenciones de múltiples disciplinas para hacer visibles las formas y los códigos de la heteronormalidad (y, por qué no, de la homonormalidad) en los medios hegemónicos.

En la medida de que estamos asistiendo a un proceso permanente de transformación de las tecnologías que utilizamos para informarnos, comunicarnos y entretenernos, vemos que la era de la digitalización ha reconfigurado los modos de sociabilidad y de interactividad que le eran anteriores. Claro está que lo "nuevo" de las tecnologías digitales no es su potencial interactivo sino su programabilidad, lo que deriva en una interacción mayor no solo entre sujetos sino también entre las personas y los softwares que utilizan y manipulan en mayor o menor medida. Como señala Lev Manovich (2006), la interactividad no es propia de la comunicación en las redes sino que esta característica ya era propia de otros dispositivos con fines comunicativos, como las puestas en escena en las salas de teatro o la telefonía fija y móvil. Además, no todas las plataformas de Internet permiten el mismo nivel de interactividad o de participación por parte de los usuarios, si bien estos sí pueden acceder nuevamente en mayor o menor medida a crear o diseñar un sitio y a adaptarlo a los fines que les deseen otorgar. Para Manovich, la posibilidad de programar las redes deviene de la analogía entre los medios informáticos interactivos y las estructuras de la mente humana, por la cual los primeros exteriorizan y objetivan las operaciones mentales mediante asociaciones o hipervínculos que guardan similitud con las potencialidades de una computadora, ya sea resolver problemas o almacenar información, entre otras cosas. 
Si bien esta postura es criticable, coincide con la de otros autores que encuentran en los medios digitales un carácter protésico y que resaltan su potencial interaccional. Uno de ellos, Federico Gobato (2014), argumenta que las interfaces artefactuales son elementos y estructuras interaccionales para la producción de la comunicación y la construcción de mundos sociales co-presenciales. ${ }^{4}$ En este sentido, gracias a las tecnologías de la comunicación mediada por la digitalización y la virtualidad tienen lugar relaciones de interacción ritualizadas y procesos de comunicación mediados y no necesariamente masivos. Estas son también tecnologías de la palabra, donde se avanza hacia un proceso de oralización de la escritura y hacia la creación y estandarización de nuevos géneros estilísticos. Agrega que las computadoras con su conexión a Internet operan como prótesis materiales y culturales, ampliativas y supletorias, postura que se asemeja a la de algunos teóricos feministas y queer. Pero más allá de pensar en las tecnologías comunicacionales como extensiones del cuerpo o de la mente humana, o como un sustituto de ellos, creemos más necesario concentrarnos en la cualidad interaccional de las tecnologías digitales, ya que más nos interesan los modos de sociabilidad mediada por las tecnologías digitales y la palabra escrita.

\subsection{Hacia una nueva ley antidiscriminatoria}

En esta sección nos adentramos en el estudio de las políticas, normativas y regulaciones nacionales e internacionales que recaen sobre Internet. El desarrollo de las tecnologías digitales reconfiguró el modo en que percibimos y transitamos nuestras vidas cotidianas así como también obligó a revisar las legislaciones existentes y a crear nuevas para atender las nuevas problemáticas asociadas a Internet. Esto abrió interrogantes respecto a la relación entre el derecho a la libertad de expresión y el derecho a una vida libre de discriminación. Sabemos que en la actualidad Argentina hay organizaciones gubernamentales y otras de la sociedad civil que abogan por la actualización de las leyes locales en vistas a garantizar el acceso y el uso igualitario de Internet y una de ellas es la Ley contra la discriminación.

Según Sandra Braman (2011), las políticas públicas sobre Internet y aquellas cuyos alcances incluyen a la web suelen ser adaptaciones de regulaciones y normativas estatales y gubernamentales ligadas a medios de comunicación anteriores y a otras

\footnotetext{
4 El sociólogo de hecho habla de "escenarios sociales", siguiendo la metáfora teatral y la teoría
} goffmaniana. 
esferas sociales, políticas y económicas. En otros casos, son específicas de la infraestructura y los usos de Internet o bien reactualizan viejas normativas cuyos sustentos se vieron transformados por los entornos virtuales. Estos cambios son resultado de la digitalización y la expansión global de la innovación tecnológica y de la infraestructura informacional, el achicamiento de los estados, la privatización y la desregulación de las redes de comunicación y la construcción de oligopolios de las industrias y corporaciones de la información y la comunicación.

Agrega que los estudios sobre Internet que abordan la cuestión de las políticas hoy se ocupan de cuatro asuntos clave: el acceso a Internet, el acceso al contenido, los derechos de propiedad y los derechos de privacidad. Para la autora, puede haber obstáculos a la libertad de expresión si alguno de estos cuatro elementos se ve limitado o si no se garantiza su protección. El que más nos importa para nuestros objetivos remite a la cuestión del acceso al contenido. Braman indica que los gobiernos pueden regular los mensajes que circulan en Internet y nuestro acceso a ello debido al factores que varían según la época, el lugar y las coyunturas políticas y socioculturales. Los ejemplos más claros remiten a la regulación sobre pornografía infantil y la vigilancia sobre las comunicaciones privadas en la era post-2001 con el pretexto de la seguridad nacional en Estados Unidos.

Por otra parte, la falta de acceso físico a la red, la falta de conocimientos para usar Internet y las barreras culturales pueden evitar la participación igualitaria en la web, profundizando las desigualdades socioeconómicas preexistentes. Otro es el derecho a la propiedad, que llevó a ampliar el sistema propietario y a transformar las nociones de propiedad intelectual y de uso justo (fair use). Otras barreras que pueden interceder en la libertad de expresión son las condiciones de acceso de licencias, costos y limitaciones en el tiempo del servicio o en el tipo de actividad que se puede realizar online y la falta de neutralidad en la red. La privacidad en la web no es tampoco un dato menor, ya que la falta de privacidad en las comunicaciones, la vulneración del anonimato y la falta de protección sobre los datos privados pueden reducir el goce de las libertades individuales. La autora señala que no hay consensos acerca de cómo resolver estas cuestiones en tanto pueden ser abordadas desde distintas perspectivas y con diferentes concepciones acerca de qué es Internet y para qué sirve. Alguna de estas posiciones pueden ser contradictorias entre sí y pueden contrastar incluso entre organizaciones civiles, corporaciones, gobiernos, jueces y legisladores; entre acuerdos, tratados, leyes y decretos; entre entidades transnacionales, entre miembros de distintos 
países y entre personas de un mismo país con respecto a algunos de sus estados o provincias o municipalidades.

Siguiendo una línea de pensamiento similar, para Victoria Nash (2013) lo paradójico de Internet es que a la vez que potenció la libertad de expresión, también generó preocupaciones sobre los contenidos que circulan en ella y creó nuevos mecanismos de vigilancia y control. Afirma que la libertad de expresión, entendida a nivel internacional como un derecho fundamental a expresarse sin la censura estatal, no es un derecho absoluto que no conoce excepciones. De hecho, no hay ningún estado que en mayor o menor medida no imponga algún tipo de limitación o de excepción a este derecho. Algunas son restricciones menos controvertidas que otras, como el caso ya nombrado de la pornografía infantil. Otros estados equiparan el derecho a la libertad de expresión con el derecho a la información, a la comunicación o a la libertad de prensa. La autora relata que existen tres miradas generales acerca de la importancia de garantizar la libertad de expresión: la primera sostiene que la misma es clave para el conocimiento y el progreso social; otra dice que es central para la democracia y según la tercera, es una cuestión de autonomía personal. Asimismo, hay cuatro ejes sobre los que se discute sobre la intervención estatal en la era digital: uno se focaliza en el derecho individual y colectivo de usar medios de comunicación para expresar opiniones, otro en garantizar el acceso a los medios, el derecho a la libertad de información y el derecho a la comunicación. La postura que se tenga sobre alguno de estos ejes cambiará las medidas o normativas que se ejecuten, dado que a la hora de tomar decisiones sobre la red intervienen múltiples actores con objetivos que pueden ser distintos.

Nash agrega que los estudios de Internet pueden ayudar a explicitar cuáles son los distintos factores y actores que expanden o restringen las oportunidades de expresarse. La penetración de la red y las variables socioeconómicas desde ya inciden en este asunto, pero también lo hace la posibilidad (o imposibilidad) de producir contenidos y de comunicarse sin censuras. Con respecto al primer ítem, estamos asistiendo a una mayor descentralización del consumo y de la producción de contendidos y a una diversificación de los flujos de comunicación. No obstante, y de manera paralela, se corre el riesgo de que se la producción de contenidos se concentre en ciertas áreas geográficas metropolitanas, como Londres y Los Ángeles. Con respecto al segundo aspecto, existen filtros y regulaciones estatales que cada vez más buscan limitar la libertad de expresión en el esfuerzo a restringir el acceso a contenido ilegal y a contenido que se cree que es potencialmente dañino. Claro que esto no está libre de 
controversias y quienes se oponen a estas medidas defienden diferentes posturas. Algunas de ellas abarcan la creencia de que las técnicas de filtrado son imprecisas o ineficaces, que además puede correrse la frontera de lo que se incluye dentro del discurso amparado por la ley. Otros argumentan que estos filtros eliminan la responsabilidad individual para tomar decisiones o que pueden menoscabar aquello que se considera valioso de Internet, como la innovación y la creatividad. Por ello hay agencias de gobiernos tanto democráticos como dictatoriales que están optando por tomar otras medidas, como bloquear el acceso a determinados sitios o darlos de baja, restringir el acceso al servicio, el financiamiento de blogs, páginas y comentaristas para influenciar las discusiones online a favor de un partido político; incluso han llegado a la persecución, detención, asesinato o a la amenaza de tomar acciones legales en contra de usuarios, bloggers y productores de contenidos de la web. Asimismo, hay otras medidas con mayor legitimidad social como los filtros y los controles que están ligados a la infracción del derecho de autor, al discurso de odio, a la difamación, a la protección de la privacidad y a la protección infantil.

Luego, Nash indica que todos estos elementos están dando forma e incidiendo permanentemente sobre la libertad de expresión en Internet. La cuestión, a fin de cuentas, es pensar cuántas regulaciones son necesarias y cuándo ya son demasiadas. Quienes abogan por la abstención de la intervención estatal y a favor de la autoregulación del espacio digital ignoran el rol que juegan actores ligados a las organizaciones no gubernamentales o al sector privado, sumado al hecho de que cada uno de estos velará por sus objetivos y quizás no tanto por la protección de los derechos fundamentales de las personas. En tal caso, la autora concluye en que será necesario que los gobiernos que decidan limitar la libertad de expresión tomen acciones que sean transparentes, enfocadas en los riesgos potenciales y midiendo su eficacia, con el fin proteger a los sectores vulnerados y minimizando los riesgos de que esta medida sea percibida como una represión a la libertad de expresión. Por último, sostiene que los estudios de Internet juegan un rol clave en tanto pueden atender a los múltiples elementos que inciden en las políticas sobre Internet y en los modos en que se ejerce (y se entiende) la libertad de expresión en el contexto actual.

Pero hay una porción del espacio digital que escapa a las regulaciones y controles de los estados y de las agencias de seguridad e inteligencia y que aun así cuentan con mecanismos de control y regulación de sus contenidos, poniendo restricciones al ejercicio del derecho en cuestión. Tal es el caso de lo que se observa en 
la investigación etnográfica que realiza Robert Gehl (2016) en una red social de la dark web, aquella región de Internet a la que solo se puede acceder a través de The Onion Router (TOR) y con ciertos conocimientos especializados sobre informática. ${ }^{5}$ El autor reconoce que desde los medios de comunicación hoy se representa a la dark web como aquel espacio destinado a actividades ilegales como la venta de drogas, contrabando de armas, consumo de pornografía infantil y contratación de sicarios, entre otros ilícitos. Los periodistas suelen suscitar pánicos que demonizan a la dark web y que implícitamente demandan legislaciones para regular todas aquellas actividades que se sitúan fuera de la clear web. La sospecha recae sobre el hecho de que la actividad de los usuarios es anónima dado que se esconde su dirección IP, no deja rastros ni cookies ni se almacenan sus datos personales; las páginas no aparecen en los motores de búsqueda y son ajenas al control de organismos como la National Security Agency (NSA). ${ }^{6}$ A ello le atribuye Gehl el aumento de usuarios de la red social que analiza, donde percibe que hay conversaciones de todo tipo y cubren un espectro amplio de intereses, que van desde grupos de discusión sobre política o filosofía a otros sobre hacking, drogas, Bitcoins e intercambios de archivos. A la vez, permanentemente se disputan las nociones de poder y de libertad. Incluso se publicó un manifiesto que aboga por el anonimato, donde se les solicita a los participantes que no provean información que permita su identificación registral.

Gehl afirma que la red social de la dark web puede potenciar la libertad de expresión al crear prácticas que desafían la vigilancia corporativa y estatal, a pesar de estar atravesada por algunos mecanismos autorregulatorios no gubernamentales que coartan el ejercicio de este derecho. En el sitio que observa hay administradores, que se autoatribuyen las tareas de vigilancia y regulación para preservar funcionamiento de la plataforma y contactan a los usuarios en caso de estar infringiendo alguna de las normas explicitadas en las condiciones de uso. Los administradores argumentan que el objetivo

\footnotetext{
5 El autor distingue entre la deep web y la dark web. En la primera, los contenidos de la red no están indexados en los motores de búsqueda comerciales. En el segundo caso, se trata un subgrupo de sitios y contenidos de la deep web que oculta la identidad y la localización de sus usuarios y de sus proveedores. A ella solo se puede acceder a través de la conexión a redes específicas, como TOR. El resto de los sitios a los que normalmente se accede desde buscadores como Google recibe el nombre de clear web.

6 Se recordará que en 2013 Edward Snowden reveló que esta agencia monitoreaba y almacenaba todas las comunicaciones digitales y realizaba tareas de inteligencia, vigilancia y control a través de redes sociales como Facebook. Por otra parte, revelaciones recientes muestran que el FBI adquirió sitios de pornografía infantil de la dark web para hackear a quienes realizaran descargas de dicho material. Para rastrear su paradero, se les enviaba un malware que identificara su dirección IP, hecho que arrojó datos de usuarios de 120 países e hizo emerger preguntas a nivel internacional sobre el accionar de las agencias gubernamentales sobre la jurisdicción de sus normas, la ética, la legalidad, la soberanía y la privacidad digital (Cox, 22 de noviembre de 2016).
} 
de esta red social es habilitar el intercambio libre de voces que de otro modo no podrían distribuirse porque en ciertos países se las considerarían ilegales y podrían traer aparejadas represalias. Sus intenciones son desarrollar "un entorno seguro y moderado para el intercambio productivo de información" (2016: 1232). ${ }^{7}$ Rechazan por completo cualquier tipo de reglamentación estatal, si bien coinciden con ella en la importancia de prohibir la pornografía infantil. Por ello proceden a bloquear las cuentas de quienes no cumplan con esta norma mientras que solicitan a los usuarios que denuncien a los infractores.

Pero, ¿qué ocurre en la clear web, donde se encuentran los blogs que analizamos? ¿Y qué sucede en Argentina con la libertad de expresión en relación con las tecnologías digitales? Salvando los condicionantes económicos, tecnológicos y socioculturales que pueden incidir en el ejercicio y el goce de este derecho, ¿de qué modo se regula la comunicación en Internet en este país? Observamos que hoy en Argentina existen leyes nacionales y regionales así como medidas judiciales que se puede pensar que coartan la libertad de expresión. Estas medidas se encargan de la protección de las personas ante casos de daños al honor, perjuicios, calumnias e injurias, difamación, discriminación y hostigamiento. Algunas de ellas contemplan apartados ligados a Internet o son específicas para el medio; otras pueden aplicarse de igual modo en instancias judiciales pese a no ser específicas del espacio público digital. Asimismo, se está debatiendo acerca de la posibilidad de normar sobre los contenidos y los comentarios publicados en las páginas web, aunque estas discusiones no están libres de obstáculos éticos, político-ideológicos y legales. ${ }^{8}$

Para hacer una síntesis general sobre las normas existentes antes de pasar al debate específico sobre la regulación de los contenidos en la web en este país, debemos nombrar en primer lugar a la Constitución Nacional en lo referido a la igualdad de las personas ante la ley y al derecho a la no discriminación. Además hay declaraciones, pactos, convenciones y tratados internacionales que establecen obligaciones para el país de modo que se garanticen los derechos de sectores minoritarios para que prevalezca el

\footnotetext{
Traducción propia del siguiente fragmento: “[...] a safe and moderated environment for the productive exchange of information".

Aquí solo nos centramos en las normas que se relacionan con los medios, la libertad de expresión y el derecho a la no discriminación. Basset et al (2016) profundizan específicamente sobre las leyes relacionadas con la discriminación en el país y señalan que la legislación vigente protege sobre todo a sectores minoritarios como las mujeres, discapacitados, personas trans, migrantes e infantes. A pesar de esto, identifican que hace falta mayor intervención estatal para que se lleven adelante medidas educativas y estrategias de inclusión y concientización con el objetivo de promover el respeto y la igualdad entre las personas y poner fin a la discriminación.
} 
principio de igualdad. ${ }^{9}$ Ello se reitera en el Código Civil y Comercial (Ley 26.994/2014), que abarca la figura de daños y perjuicios y que es aplicable a Internet, como ocurrió con la causa contra la revista Barcelona. ${ }^{10}$ Otro cuerpo normativo que es de interés para esta investigación es el Código Penal de la Nación y sus modificatorias, como la Ley 26.388/2008 de Delitos Informáticos, donde por ejemplo se contempla la protección de la confidencialidad de las comunicaciones y la penalización de la producción y distribución de contenido sexualmente explícito con menores de 18 años. Por otra parte, la Ley 26.551/2009 refiere a las calumnias e injurias y también modifica al Código Penal; deroga la pena a prisión hacia quienes cometiesen el delito, aplicando en su lugar multas, y exime a quienes se expresen sobre asuntos de interés público.

Otras leyes se encargan de la promoción de la libertad de expresión y de impedir la discriminación en los medios de comunicación radiales, audiovisuales y digitales. Para continuar con este mapeo normativo, debemos hablar de la Ley 14.241/1953 del Servicio de Radiodifusión, que entiende a los medios como un servicio público para el acceso a la cultura. Allí se vela por la transmisión de contenidos afines a la moral y a las buenas costumbres, que no puedan provocar alarma pública ni suscitar polémica (Recalde, 2008). Características similares tiene el decreto reglamentario 5490/65, que modifica al decreto ley 15.460/1957 de Radiodifusión y Televisión y que expresamente indicaba "abstenerse de narraciones o escenificaciones de actos delictuosos o que signifiquen la apología del delito o alienten o contribuyan a difundir vicios o que expresen perversión o sentimiento subalterno" (art. N del decreto 5490/65, citado en Elíades, 2003: 44-45). Asimismo, allí se sugería que la programación debía "abstenerse de los programas que exalten el triunfo del mal sobre el bien, la disolución de la familia, la traición a la patria, el vituperio a los forjadores de la nacionalidad, la burla a los defectos físicos, el desvío sexual o el erotismo" (art. Ñ, Elíades, 2003: 45). La conservación de una moral sexual hegemónica y la delimitación sobre los contenidos de la programación radial y audiovisual se reiteran en la Ley 19.798/1972 de

\footnotetext{
9 Esto incluye la Declaración Universal de Derechos Humanos, la Declaración Americana de los Derechos y Deberes del Hombre, la Convención Americana sobre Derechos Humanos "Pacto de San José", "Protocolo de San Salvador", Convención contra la tortura y otros tratos o penas crueles, inhumanos o degradantes, Pacto Internacional de Derechos Civiles y Políticos, la Declaración sobre Orientación Sexual e Identidad de Género de la Organización de Naciones Unidas y los Principios de Yogyakarta (FALGBT, 2017).

10 La revista Barcelona suele satirizar sobre figuras de la coyuntura política argentina. Difunde sus notas de forma digital de manera gratuita y también vende ejemplares impresos. En mayo de 2016 se falló en contra de la revista Barcelona por daños a la moral de la denunciante, Cecilia Pando, obligando a sus responsables a abonar una multa de $\$ 40.000$. El medio rápidamente apeló esta decisión.
} 
Telecomunicaciones, que indica que "no se cursará telecomunicación alguna que pueda afectar la seguridad nacional, las relaciones internacionales, la vida normal de la sociedad y sus instituciones, la moral y las buenas costumbres" (art. 17).

Por otra parte, la Ley 22.285/1980 de Radiodifusión busca defender los derechos humanos, el decoro, la familia, la seguridad nacional y la moral cristiana (art. 5, modificado por el decreto 1005/99). El derecho a una vida libre de discriminación y el derecho a la comunicación se consolidan con la Ley 26.522/2009 de Servicios de Comunicación Audiovisual. Entre otras cosas, establece que:

La programación de los servicios [radiales y audiovisuales] previstos en esta ley deberá evitar contenidos que promuevan o inciten tratos discriminatorios basados en la raza, el color, el sexo, la orientación sexual, el idioma, la religión, las opiniones políticas o de cualquier otra índole, el origen nacional o social, la posición económica, el nacimiento, el aspecto físico, la presencia de discapacidades o que menoscaben la dignidad humana o induzcan a comportamientos perjudiciales para el ambiente o para la salud de las personas y la integridad de los niños, niñas o adolescentes (art. 70)

Además, impulsa la creación de la Defensoría del Público para velar por los derechos de las audiencias y fomenta la pluralidad de voces a través de la democratización de licencias de radiodifusión y de servicios de comunicación audiovisual. Luego, la Ley Argentina Digital 27.078/2014 ordena y garantiza la neutralidad de las redes y el acceso equitativo a las tecnologías de la información y la comunicación sin restricción ni discriminación.

A fines de 2015 esta ley fue derogada junto con la Ley 26.522/2009 mediante el decreto 267, que deja intactos los apartados referidos a la libertad de expresión y a los otros derechos mencionados, si bien realiza modificaciones en otros aspectos clave que pueden actuar en perjuicio de los derechos de los sectores minorizados. Parece ser que el común denominador entre las normas que nombramos es que todas sugieren defender la libertad de expresión a través de distintos mecanismos que pueden favorecer o entorpecer el goce igualitario de los derechos de las personas. Estas legislaciones se ocupan en mayor o menor medida a la sanción de la discriminación, ya que como vimos solo las más recientes se encargan explícitamente de ello, mientras que las anteriores acentuaban el interés por la defensa de la moral cristiana y las buenas costumbres, en 
rechazo de todo aquello que se considerara que constituía un vicio, una perversión, un sentimiento subalterno o una desviación sexual.

Por último, en noviembre de 2016 se aprobó en el Senado un proyecto de ley que resultó de la unificación de dos proyectos (1865-S-15 y 942-S-16). Allí se establece que los proveedores de servicios de Internet no son responsables de los contenidos que circulan, se almacenan y se alojan en la web. Lo mismo sucede con los proveedores de servicios de acceso, transmisión, interconexión y direccionamiento de los datos, salvo que tengan conocimiento de la circulación de contenidos que violen las normas legales o los derechos de terceros y no los eliminen. En la lista de contenidos ilegítimos se nombra la apología e incitación a la violencia, la discriminación y los daños al honor, la intimidad y la imagen de las personas, entre otros.

Hasta aquí llegamos con las leyes que fueron creadas específicamente en relación con los medios de comunicación. Por otro lado, hay leyes con un alcance que excede a los medios y que abarca a la sociedad toda, como por ejemplo la Ley 23.592/1988 de Penalización de Actos Discriminatorios. Esta se orienta a prohibir los actos $\mathrm{u}$ omisiones discriminatorios determinados por motivos como raza, sexo, nacionalidad, ideología, religión, opinión política o gremial, caracteres físicos, posición económica o condición social. El interés por garantizar el derecho a la no discriminación se reitera en el artículo $65^{\circ}$ del Código Contravencional de la Ciudad Autónoma de Buenos Aires (Ley CABA 1.472/2004). ${ }^{11}$ Pero la ley de la Ciudad Autónoma de Buenos Aires 5.261/2015 contra la Discriminación es aún más completa, porque también abarca actos, hechos u omisiones con respecto a la orientación sexual, género, identidad e identidad de género de las personas. Activistas por los derechos de las personas LGBTIQ quieren incorporar estos aspectos en la legislación nacional y que se traten los proyectos de ley para tal fin, como se sostuvo en la XXIV Marcha del Orgullo del 2015 cuyo lema fue "Ley antidiscriminatoria ya!". ${ }^{2}$

En 2014 se presentaron proyectos de ley para modificar y actualizar la Ley Nacional de Actos Discriminatorios, que actualmente no contempla la discriminación por orientación sexoafectiva e identidad y expresión de género. No obstante ello, desde hace más de veinte años que numerosas organizaciones vienen presentado en el

\footnotetext{
11 Estos mismos códigos contravencionales que son usados para defender a las personas ante casos de violencia y discriminación, fueron usados en numerosas ocasiones para detener y perseguir a las personas LGBTIQ, especialmente a las mujeres trans.

${ }^{12}$ Este reclamo se repitió en la edición de la marcha de 2016 y ya había formado parte de las demandas del colectivo en años anteriores.
} 
Congreso proyectos similares, aunque han perdido estatuto parlamentario. Algunas de ellas son la Comunidad Homosexual Argentina, la organización 100\% Diversidad y Derechos y la Federación Argentina LGBT, quienes trabajan junto con organizaciones y legisladores de distintas fuerzas políticas. Estos proyectos no eran del todo idénticos, pero finalmente se acordó unificar las iniciativas en el expediente 9064-D-14, que perdió estatuto parlamentario en 2016. Este proyecto de ley era novedoso ya que proponía ampliar el alcance de lo que se considera como actos discriminatorios e invertía la carga de la prueba. Se define a los actos discriminatorios como:

Las acciones y/u omisiones, de autoridades públicas o de particulares, que, de manera arbitraria, tengan como finalidad o resultado impedir, obstruir, restringir, o de algún modo menoscabar de forma temporal o permanente, el reconocimiento, goce o ejercicio, en condiciones de igualdad, de los derechos y garantías fundamentales reconocidos por la Constitución Nacional, los tratados internaciones [sic], las leyes y normas complementarias, a personas, grupo de personas o asociaciones, motivadas en la falsa noción de raza, así como en las nociones de etnia, nacionalidad, lengua, idioma o variedad lingüística, religión o creencia, ideología, opinión política o gremial, sexo, orientación sexual, género, identidad de género y/o su expresión, edad, color de piel, estado civil, situación familiar, filiación, embarazo, discapacidad, responsabilidad familiar, antecedentes o situación penales, trabajo u ocupación, lugar de residencia, caracteres físicos, características genéticas, capacidad psicofísica y condiciones de salud, posición económica o condición social, hábitos personales o cualquier circunstancia que implique distinción, exclusión, restricción o preferencia (Expediente 9064-D-14, artículo 5).

Como dijimos, este proyecto se complementó con otros, siendo uno de ellos el que presentó Remo Carlotto en la Cámara de Diputados en 2014 por la promoción de la no discriminación en Internet bajo el número de expediente 7379-D-14. Durante su tratamiento en la Comisión de Derechos Humanos se decidió incorporar un artículo general sobre la discriminación en Internet en el proyecto del expediente 9064-D-14, para lo cual hubo consenso excepto por la firma en disidencia de dos diputados. También se acordó sacar ese artículo si era necesario para que avanzara la ley. Finalmente, este proyecto perdió estado parlamentario porque no se lo incluyó en el temario de la Comisión de Legislación Penal que debía tratarlo. La FALGBT junto con otras organizaciones y legisladores presentaron un nuevo proyecto bajo el expediente 
1552-S-2016, que abarca la discriminación en medios sonoros y audiovisuales pero no en los medios digitales. Lo mismo sucede con el proyecto 4447-D-2016 que impulsaron la CHA y 100\% Diversidad y Derechos el 15 de julio de 2016; allí se urge al Estado Nacional a promover políticas educativas inclusivas y otras políticas reparatorias e igualitarias para erradicar los cimientos culturales sobre los que se edifica la discriminación contra las personas. ${ }^{13}$

Pero volvamos a los proyectos que buscan establecer regulaciones sobre los contenidos que circulan por Internet, el expediente 7379-D-14 y el expediente 9064-D14. El primero comienza con las siguientes definiciones:

CONTENIDO DISCRIMINADOR. Será considerado contenido discriminador aquellos mensajes publicados en las plataformas de contenidos producidos por los usuarios que menoscaben o insulten a las personas por su condición étnica, de color, de nacionalidad, religión, género, identidad de género o su expresión, orientación sexual, edad, estado civil, trabajo u ocupación, caracteres físicos, capacidad psicofísica, condición de salud, perfil genético o pobreza. La presente enumeración no es taxativa y el carácter discriminador deberá ser evaluado con arreglo a la ley 23.592 de Actos Discriminatorios y los instrumentos internacionales de derechos humanos suscriptos por nuestro país.

Plataformas de contenidos de usuarios: son páginas, blogs, redes sociales, agencia de noticias, medios de prensa, diarios on line, revistas electrónicas y otros sitios de internet que admiten que los usuarios publiquen contenidos, opiniones o dejen mensajes en sus respectivos dominios (Expediente 7379-D14 , artículo $2^{\circ}$ ).

El segundo expediente contiene un solo artículo referido a la red y expresa que:

Los administradores de sitios de internet que dispongan de plataformas que admitan contenidos y/o comentarios subidos por los usuarios están obligados a: a) publicar términos y condiciones $[\ldots]$ con el objeto de informar sobre el carácter discriminatorio de un contenido y la legislación vigente al respecto; b) disponer y hacer pública una vía de comunicación para que los usuarios

\footnotetext{
13 Gerardo Zamora también presentó un proyecto para legislar sobre Internet bajo el expediente 4725-S16 con el fin de actualizar la Ley 26.485 de Protección integral a las mujeres. Su objetivo era ampliar el artículo 1, inciso $\mathrm{F}$, para que la definición de violencia mediática abarque los mensajes e imágenes estereotipados publicados y difundidos a través de las redes sociales.
} 
denuncien y/o soliciten la remoción del material que se encuentre en infracción a esta ley (Expediente 9064-D-14, artículo 21%).

Mientras que el primer proyecto de ley incluye mecanismos de regulación de contenidos en la web, el segundo más bien establece condiciones de uso para las plataformas digitales.

Pese a las diferencias entre ambos, varias personas se opusieron a estas propuestas alegando que constituían una forma de censura previa. En primer lugar, hubo confusión mal o bien intencionada entre los diferentes proyectos que circularon, lo que contribuyó a aumentar el interés mediático sobre el asunto (CELS, 2015). Luego, cuestiones políticas se filtraron en el debate y en 2014 y 2015 se publicaron varios artículos periodísticos que hablaban sobre cómo estas leyes eran violatorias de acuerdos y convenciones internacionales. Así, se observó que los detractores de estos proyectos decían que se buscaba censurar y reprimir los comentarios online y restringir el acceso a Internet. Decían temer por la libertad de expresión en Internet, garantizada hoy como el derecho de buscar, recibir y difundir información a través de ella (CELE, 2013). ${ }^{14}$ Luego pidieron que no se responsabilice a los sitios donde se publican comentarios discriminatorios dado que se cree que estos no tendrían por qué contar con los medios técnicos y los recursos humanos para moderar contenidos. Y agregaron que el fuero penal no es el pertinente para acabar con la discriminación y que en todo caso esto puede presentar un riesgo para la libertad de expresión para el goce del derecho a la comunicación y a la información (Busaniche, 2015).

En paralelo, una normativa internacional que suscita interrogantes similares: la ley estadounidense conocida como Digital Millennium Copyright Act (Ley de Derechos de Autor de la Era Digital; DMCA por sus siglas en inglés). Nacida en 1998, esta ley tiene jurisdicción en Estados Unidos pero abarca los sitios, redes sociales y buscadores que se utilizan en Argentina que legalmente se radican en el país anglosajón. Según

\footnotetext{
${ }^{14}$ Hasta ahora en Argentina son pocas las medidas judiciales por difamación o daños y perjuicios que efectivamente derivaron en la eliminación de contenidos de la web o en el bloqueo del tráfico o el acceso a determinadas URL. En la mayoría de esos casos, la responsabilidad recayó sobre los intermediarios, generalmente los buscadores Google y Yahoo! (CELE, 2013). Algo similar puede decirse sobre la protección del derecho de datos personales y el derecho al olvido a partir de demandas judiciales hechas contra los buscadores Google y Yahoo! para solicitar la eliminación de material que atentara contra los derechos fundamentales de algunos ciudadanos, tal como sucedió con Florencia Peña y la difusión de un video donde se la mostraría teniendo relaciones sexuales. Si bien por un lado la eliminación o desvinculación de los contenidos puede asegurar la protección de los derechos de una o varias personas, por otro lado puede obturar la libertad de aquellas que busquen acceder a dicho material, ya sea en el caso de celebridades como Peña o en el de un político, funcionario o cualquier otra figura pública.
} 
Eduardo Bertoni y Sophia Sadinsky (2015), la DMCA puede violar los estándares mundiales de libertad de expresión dado que se la puede emplear con fines políticos para censurar voces opositoras las fuerzas políticas de turno. Los autores señalan que tanto las Naciones Unidas, los sistemas Inter-Americanos de Derechos Humanos y los estándares europeos refieren a la necesidad de no obstaculizar la libertad de expresión en la web ya que aquella es un principio democrático y un derecho fundamental de las personas. Por consiguiente, solo se deben regular los contenidos cuando incluyen material que no está amparado por la libertad de expresión, como aquellos que incitan al odio o que hacen apología del delito. No obstante, observan que hubo ocasiones donde se eliminaron contenidos digitales que no calificaban como discursos de odio. Por lo tanto, las regulaciones de Internet podrían coartar la libertad de expresión incluso en discursos amparados por la ley y así interferir en el goce de los derechos humanos (Busaniche, 2015; CELE, 2013).

En este sentido, la Relatoría Especial para la Libertad de Expresión de la Comisión Interamericana de Derechos Humanos (CIDH, 2015a) difundió un informe anual con una serie de advertencias con respecto a la regulación de los contenidos en la web. En primer lugar, el organismo manifiesta su preocupación por los proyectos de ley argentinos: les critica su intención de penalizar los actos discriminatorios en la web y su interés por colocar a los medios en el rol de censores. En el informe se señala que toda ley que busque regular los contenidos en Internet debe ser redactada cautelosamente e incluir apartados que limiten su alcance con el fin de prevenir todo tipo de abusos. Se indica que las medidas de sanción o castigo deben ser proporcionales y solo ceñirse a los discursos que no están amparados por el derecho a la libertad de expresión. De este modo, las discusiones en los foros virtuales debieran ser moderadas solo en las condiciones en las que ello sea razonable.

Más adelante, el organismo afirma que la definición de la figura del discurso de odio debe ser lo más precisa posible para prevenir que se hagan usos políticos inadecuados de esta categoría en asuntos de interés público. Por ello debe definirse $a$ priori qué es un discurso de odio para proteger a individuos o grupos de personas que, por ejemplo, sean atacados por su orientación sexual, su identidad y su expresión de género. Las soluciones oscilan entre la aplicación de sanciones monetarias, el impulso de medidas preventivas y socioeducativas, la vigilia ciudadana y la promoción de políticas públicas de acceso a Internet y de protección de las personas en las redes. En 
Argentina, algunas de estas tareas las desarrollan los integrantes la Plataforma por una Internet Libre de Discriminación del INADI.

Sin embargo, se sostiene que la libertad de expresión no es un derecho absoluto y que debe estar sujeto a limitaciones si y solo si ha de cercenar el derecho a la igualdad de las personas y el derecho a una vida libre de discriminación. En este sentido, se afirma que todas las personas deben estar en igualdad de condiciones y contar con igualdad de oportunidades, por lo que la falta de recursos para que las personas LGBTIQ puedan dar a conocer sus necesidades y problemáticas en los medios de comunicación es un limitante a su libertad de expresión y a su condición de igualdad. Asimismo, se alega que la discriminación en línea puede conducir a que las personas LGBTIQ dejen de participar en estos sitios o que cierren sus perfiles en las redes sociales, algo que debería prevenirse ya que no puede haber democracia ni pluralidad de voces si hay grupos marginados que no pueden acceder a los medios necesarios para formar parte de debates públicos o si no se sienten seguros al hacerlo. Por ello, los medios de comunicación, al igual que los funcionarios estatales, deben garantizar la participación en igualdad, respetar los Principios de Yogyakarta e incluir a las personas LGBTIQ en sus agendas políticas, además de promover su aceptación y evitar mostrarlas de manera estereotipada.

Podemos sintetizar la postura de la Relatoría para la Libertad de Expresión de la CIDH con la siguiente cita:

Internet constituye una herramienta esencial para que las comunidades vulnerables o históricamente discriminadas obtengan información, expongan sus agravios, hagan oír sus voces y participen activamente en el debate público y contribuyan en la construcción de políticas públicas tenientes a revertir su situación.

Sin embargo, también se han documentado instancias de discriminación en línea en detrimento de grupos particularmente vulnerables, incluyendo mujeres, niños, la comunidad LGBTI, migrantes, discapacitados, entre otros. Los Estados deben adoptar medidas para promover la igualdad y la no discriminación tanto "online" como "offline", prohibiendo el discurso de odio que incite a la violencia, documentando las instancias de discriminación y promoviendo la tolerancia a través de programas sociales, capacitación y educación (CIDH, 2017: 426). 
En cambio, Iginio Gagliardone et al (2015) apuestan menos a las vías legales y más a la acción ciudadana para contrarrestar los discursos de odio en línea. Por lo tanto, para que los usuarios puedan participar en la web con dignidad, seguridad e igualdad, será necesario que se elaboren acciones de identificación, monitoreo, moderación, reporte y respuesta ante los mensajes degradantes. ${ }^{15}$ Pero será igual de importante que las organizaciones públicas y privadas midan el poder, el impacto y el alcance de los contenidos degradantes para elaborar respuestas situadas en conjunto con otros actores sociales que vean que sus derechos son vulnerados, atendiendo a la amplitud y a la inmediatez de la difusión de los mensajes seudo-anónimos que circulan en Internet.

Ahora bien, parece pertinente traer a colación un estudio que hizo Danielle Keats Citron (2009), quien habla sobre las consecuencias de los casos de violencia en Internet en Estados Unidos. Afirma que las mujeres que son acosadas, agredidas, difamadas, hackeadas y amenazadas por Internet a veces eligen dejar de participar en Internet o esconder sus identidades de género con el fin de no ser victimizadas. Todo esto tiene un impacto negativo en sus vidas, no solo por las intimidaciones, los daños reales y potenciales y las denuncias desoídas en las comisarías sino también porque la falta de presencia online en el mercado laboral actual las vuelve menos competitivas en relación con los hombres, lo que acentúa la brecha digital de género y las desigualdades socioeconómicas entre hombres y mujeres.

A su vez, Citron observa que los casos de acoso cibernético comparten algunas características con los de acoso laboral y de violencia doméstica: inicialmente, los dos últimos fueron trivializados y desestimados en los fueros penales y judiciales. Pero en la red no siempre es tan sencillo identificar a los agresores como en los otros casos; los perfiles anónimos y los mecanismos para esconder la IP contribuyen a escapar de todo tipo de sanción. Por ello, Citron se pregunta por los alcances y limitaciones de una ley referida al acoso en Internet para concluir que su valor principal recaería especialmente sobre su valor expresivo y simbólico, para destrivializar estos hechos y contribuir a su erradicación. Por esto valora las prácticas educativas y formativas realizadas por organizaciones como Working to Halt Online Abuse (Trabajando para Frenar el Abuso Virtual; WHOA por sus siglas en inglés).

\footnotetext{
${ }^{15}$ La pregunta sobre cómo actuar ante casos de la discriminación en Internet es compleja dado que se deben tener en cuenta varios factores: qué es un hecho violento, para quién, contra quiénes, qué hacer para frenarlo, subsanarlo y prevenirlo, y cuál es el espacio o ámbito de injerencia de una medida regulatoria. La ecuación se torna más difícil por el hecho de que hay páginas de Internet que trascienden las fronteras geográficas y desdibujan los límites de los alcances de los aparatos legislativos de cada país.
} 
Entonces, ¿tiene sentido promulgar una ley para regular los discursos discriminatorios en Internet? Quizás, como afirma Citron, el valor de una ley de estas características radica más en su potencial simbólico para problematizar el tema, concientizar a la sociedad y así acompañar procesos sociales de cambio. Además, en la medida que existan personas que sientan sus derechos vulnerados, sí parece ser necesaria la existencia de algún tipo de regulación de los contenidos discriminatorios en la web. Y si bien reconocemos que es posible que ello imponga limitaciones a la libertad de expresión, sostenemos que deben revisarse las normativas vigentes o impulsarse nuevas leyes para proteger el derecho a la comunicación, a la libertad de expresión y a una vida libre de discriminación de manera simultánea. Allí deberá delimitarse con precisión qué discursos están amparados por la ley y cuáles califican como discurso de odio o como discursos incitadores a la violencia a fin de prevenir abusos e interpretaciones según los intereses de las fuerzas políticas de turno.

Por el momento no hay soluciones precisas ante la discriminación y los hostigamientos online, más que el contraataque, la eliminación del material, el bloqueo de usuarios, la reporte en el sitio en el que se produce la agresión y el cierre de cuentas de las personas violentadas para eludir el problema. Los aparatos legales existentes no son suficientes a la hora de acabar con la discriminación, sobre todo si consideramos que Internet desdibuja las fronteras nacionales y crea nuevos interrogantes en materia de jurisdicción legal. Seguir el camino penal o judicial tampoco parece ser viable, ya que las denuncias por amenazas virtuales son desoídas en las comisarías o bien dependen de la voluntad de quienes las reciben. Las denuncias dentro de las mismas redes sociales también se atienden según las normas del sitio y según el criterio de los moderadores y administradores. ${ }^{16}$

En definitiva, Internet parece estar lejos de ser un espacio inclusivo. Como ya dijimos, en la web se perpetúan las luchas de poder que se traducen en nuevos modos de exclusión; las modalidades de la violencia se renuevan, así como las prácticas de

\footnotetext{
${ }^{16}$ Ejemplos de ello son la respuesta de los administradores de Facebook ante la denuncia del evento Marcha por la Vida y la Familia Natural que organizaba una contra-marcha en la plaza Congreso (Capital Federal, Argentina) en paralelo a la XXV Marcha del Orgullo LGBTIQ en noviembre de 2016. Los responsables de la plataforma no consideraron que allí se incitara al odio ni que los contenidos publicados en la página del evento violaban sus normas comunitarias. Otro caso se refleja en la denuncia civil que hizo el periodista Franco Torchia contra un usuario de Twitter que le enviaba mensajes violentos, homofóbicos, hostigadores y amenazantes, ante la negativa de los gestores de la plataforma por eliminar el contenido discriminatorio y violento. En ambos, las plataformas no hicieron lugar a los reclamos de los usuarios afectados y avalaron la permanencia (o no eliminación) de materiales que eran ofensivos o discriminatorios para algunas personas y colectivos.
} 
contestación que le merecen. La preocupación por los procesos sociales allí acaecidos se vincula con nuestro interés por el estudio de los modos de violencia habilitados en un entorno imaginado como la panacea de la libertad de expresión y utilizado como espacio de diseminación de discursos de odio pero también como foco de resistencia. Los recientes debates que giraron en torno a la actualización de la Ley Antidiscriminatoria y la promoción de la no discriminación en Internet han permitido entrever que la cuestión no debe ceñirse al ámbito de lo jurídico-legal: las regulaciones sobre Internet pueden tener poco eco a la hora de evitar la difusión de contenidos discriminatorios online a menos que se tomen medidas preventivas, de sensibilización y de concientización en la sociedad toda.

En este sentido, es posible que la sanción de una norma así habilite un proceso de transformación social más amplio. Los gobiernos hoy tienen una gran responsabilidad a la hora de garantizar el derecho a una vida libre de discriminación y en igualdad de condiciones para las personas LGBTIQ y otros sectores minorizados. Más aún, se deben tomar medidas reparatorias y de promoción social que impulsen la participación de las personas LGBTIQ en los ámbitos mediáticos, políticos, jurídicos, laborales, educativos y científicos a fin de asegurar un goce igualitario de los derechos y una plena participación ciudadana. Los avances en materia de derechos como el reconocimiento igualitario del matrimonio y de la identidad de género son insuficientes si no vienen de la mano de mecanismos de legitimación social y de un aparato estatal que vele por la integridad de las personas LGBTIQ; estos son los objetivos de las propuestas de actualización de la Ley Antidiscriminatoria de las que hablamos en este apartado, que en definitiva buscan poner fin a la larga historia de la discriminación contra las personas con géneros y sexualidades no normativas.

\subsection{Historia de la homosexualidad y de la homofobia}

La construcción de la diferencia estuvo siempre acompañada por distintas justificaciones y sanciones que, condicionadas por una mirada reacia hacia el otro, perpetuaba ciertos modos de ser y hacer mientras negaba otros. La historia de la homosexualidad y la de la homofobia se superponen entre sí: no se puede hablar de una sin hablar de la otra. Desde que aparecen los registros de los primeros actos sexuales entre personas del mismo sexo aparece también una mayor o menor crítica hacia ciertos 
tipos de conductas que no se condicen con las de la mayoría. En este apartado haremos una aproximación histórica de las tantas historias que circulan de los géneros y las sexualidades disidentes en la Europa Occidental y en Estados Unidos para luego hablar de Argentina. La reconstrucción que sigue es incompleta, ya que se enfoca en algunas lecturas de las tantas historias sobre aquella convención denominada "homosexualidad" y sobre el término que también por convención denota su aborrecimiento, miedo u odio, que es "homofobia". Con esto, esperamos contribuir a mejorar la comprensión sobre las demandas actuales de este sector vulnerabilizado en nuestra región.

Para empezar, y siguiendo los aportes de Byrne Fone en Homofobia: una historia (2008), el concepto "homosexualidad" como lo conocemos hoy fue acuñado en 1868 por el periodista Karl Kertbeny para referirse al deseo sexual entre personas del mismo sexo, como algo que contrastaba con la sexualidad de la mayoría de las personas. En ese mismo año también se utilizó esa palabra en una publicación del Dr. Karl Westphals, un médico alemán que la definió como un "sentimiento sexual invertido" distinta a la del resto. El uso del término se volvió popular en los años 1920, solo diez años antes de que se creara el concepto "heterosexualidad" en la década de 1930. Esto implica que primero se vio la necesidad de nombrar a la homosexualidad como algo separado de lo mayoritario, y que luego se catalogó aquello de lo que se distinguía, fijando la relación de diferenciación entre dos actores sociales. Sin embargo, como señala Fone, "aunque el término es de invención relativamente reciente, la conducta que describe siempre ha sido parte de la actividad sexual humana" (2008: 19).

Antes de desarrollar ese punto, parece pertinente definir "homofobia", que en palabras de Fone, significa "temor y desagrado por la homosexualidad y por aquellos que la practican" (2008: 20), tal como se la definió por primera vez entre las décadas de 1960 y 1970. Agrega que la homofobia:

\footnotetext{
Ha adoptado diversas formas y tiene muchos orígenes. Inventada, fomentada y apoyada a través del tiempo por diferentes agencias de la sociedad - la religión, el gobierno, la ley y la ciencia - tiende a hacer erupción con un veneno especial cuando las personas las imaginan una amenaza para la seguridad de los papeles que representan los géneros, de la doctrina religiosa o del Estado y la sociedad, o para la seguridad y la salud sexual del individuo (2008: 22)
}

Para el autor, la homofobia es producto de la educación y la socialización. Presenta múltiples formas en concordancia con el uso de estereotipos y de otros prejuicios, como 
el sexismo, el racismo, el antisemitismo y recientemente los vinculados con las personas con VIH/SIDA. Por eso prefiere hablar de "homofobias", que pueden estar presentes en actitudes, discursos y percepciones de personas heterosexuales hacia los no heterosexuales y también entre las personas LGBTIQ.

El teórico David Halperin (2000) completa esta definición al referirse a la homofobia como un conjunto de discursos que se sirven de estrategias polimorfas y cambiantes, ya sea en espacios públicos y privados, que saturan el campo de representación cultural y que por eso solo es posible resistirlos mediante mecanismos de deslegitimación. Funciona por medio de contradicciones lógicas para atacar a lesbianas y a gays y se convierte en algo difícil de identificar y de refutar, dado que se transforma permanentemente para eludir su contestación. Los discursos homofóbicos no tienen contenidos proposicionales estables y que son en todo caso intercambiables. Pero se puede resistir a ellos y para tal fin es necesario exponer sus operaciones discursivas, además de revelar las estrategias gracias a las cuales los discursos del derecho, la ciencia, la medicina y la religión han desautorizado a los homosexuales. Propone algunas prácticas de contestación, tales como la reapropiación creativa de discursos homofóbicos y su resignificación afirmativa o su teatralización, su exposición y su desmitificación. Además, señala la importancia de someterlos a una crítica política para burlar sus estrategias, deslegitimar sus pretensiones de autoridad y desmantelar su base institucional, tan arraigada en la sociedad occidental.

Fone también cree en la posibilidad de combatir la homofobia pese a observar que la misma ha sido transversal a la historia de la humanidad. Dice que:

Para cualquier observador de la historia de la sexualidad y de las actitudes sociales, la homofobia tiene que parecer una presencia constante e incluso inerradicable. La historia de la homosexualidad parece confirmar que la conducta entre miembros del mismo sexo ha sido desde hace mucho tiempo objeto de una persecución legal, social y religiosa: al igual que la homosexualidad parece ser un aspecto omnipresente de la conducta humana, en ocasiones puede parecer que también lo es la homofobia. Sin embargo, al igual que "sexualidad" y "homosexualidad" - términos que son de reciente invención y que han sufrido una reevaluación - la homofobia puede resultar ser una interpretación sensible a fuerzas históricas y sociales. Como muchas de las fuerzas de la historia, aparentemente inmutables, puede estar sujeta a transformación, e incluso a erradicación (2008: 31) 
Pero el autor también ve que los actos homosexuales no siempre recibieron la misma condena por parte de la sociedad, las religiones y los gobiernos. De hecho, y comenzando a trazar la historia de la homosexualidad, percibe que en Grecia en la Antigüedad las prácticas sexoafectivas entre hombres eran corrientes. Encuentra textos escritos por Aristóteles y Platón, por ejemplo, en los que se alababan las relaciones entre un ciudadano adulto y muchacho joven. En esta relación ideal de paiderastia, como la llamaban, se mezclaban los papeles de amante y amado con los de maestro y discípulo. Primaba lo intelectual y lo espiritual por encima de lo sexual. No obstante, Fone empieza a encontrar ciertos estereotipos peyorativos en la literatura griega hacia sujetos que son muy similares a los estereotipos de hoy: los hombres afeminados son receptores o pasivos, y las mujeres tribadistas o lesbianas son masculinas.

En Grecia, se veneraba a los hombres viriles que tenían dominio de sí y que cumplían ciertas funciones (viriles) en la vida familiar, cívica y política. Por el contrario, los hombres afeminados eran, se decía, los que intentaban imitar a las mujeres y realizar actividades como si fuesen ellas. La feminización de los hombres generaba bastante preocupación, que se vio reflejada en varios textos que intentaban delinear cuáles eran las características y conductas que debían tener los hombres "verdaderos". Fone empieza a atisbar los inicios de la homofobia en este período ya que, además, se comienza a demonizar al hombre femenino, al insaciable que no tenía dominio de sí y al que gozara de ocupar un rol pasivo en una relación sexual homoerótica; y además se empieza a creer que los hombres femeninos son simultáneamente pasivos, promiscuos, moralmente débiles y peligrosos para la sociedad, por lo que la condena social hacia quienes que presentaran algunas de estas características empieza a aumentar hacia fines de la Antigüedad.

Fone agrega que los estudiosos de la literatura y filosofía clásica han interpretado que los griegos no aceptaban la homosexualidad en absoluto, pero él señala que estas interpretaciones en realidad más responden a los prejuicios de los investigadores que a los de los griegos. Para nombrar un caso, cuando los clásicos afirmaban que la homosexualidad era "antinatural", no estaban realizando una crítica moral como las que se harían hoy, sino que, por el contrario, así denominaban a las prácticas sexuales que no tendían al fin legítimo, que era la procreación. Pero sí reconoce que entre los griegos hubo alegatos de desviación sexual para perseguir a enemigos políticos, como por ejemplo, para avergonzar y desprestigiar a un sujeto. 
En Roma la historia no era muy diferente. Si bien aceptaban la pederastia, los romanos no exaltaban las relaciones homosexuales de la misma forma que los griegos. ${ }^{17}$ Los romanos también creían que los hombres afeminados y pasivos eran monstruos pervertidos y de igual modo condenaban a quienes renunciaban a su derecho moral como ciudadanos para someterse a la penetración anal o a realizar sexo oral. Algunos opinaban que las personas que realizaran actos sexuales con alguien de su mismo sexo tenían una mente enferma y una fisonomía que se podía identificar por medio de la observación para así segregarlos, controlarlos y/o erradicarlos.

Pero Foucault (1984a, 1984b) observa que la patologización de la actividad sexual pasiva que empezó a emerger hacia fines del período grecorromano no equivalía a condenar la posición receptiva. Los incipientes regímenes médicos sí veían en ella la posibilidad de contraer enfermedades ya que, para ellos, el acto sexual en sí era un foco constante de males posibles. Todo acto sexual constituye un desgaste de energía y puede alterar al alma y al organismo; de allí la importancia del dominio de sí. Pero esta patologización no sería para nada la misma que se sostendría en la modernidad occidental para demonizar al acto sexual como portador de desviaciones enfermizas.

Esta moral fue cada vez más austera y constrictiva y estaba sometida a una lógica relacional matrimonial que articulaba naturaleza y razón en torno al cuidado de uno mismo y al arte de la existencia. La inquietud y la problematización de los actos sexuales, antes de su configuración disciplinaria en la sexualidad moderna, se vincularon con el interés por una actividad que parecía ser cada vez más peligrosa ya que era vista como la puerta de los males. Pero según Foucault, ello nunca llevó a la condena del amor entre hombres libres ni a la inclusión de sus placeres dentro del nombre de los actos contra naturales, a diferencia de la moral-sexual que vendría más adelante.

Además, los filósofos y pensadores grecorromanos que versaban sobre el amor entre muchachos no tenían posturas homogéneas al respecto. Algunos alegaban que el amor entre hombres no era igual al de hombres y mujeres ya que el primero nunca podría ser completo ni perfecto. Había quienes argumentaban que en el matrimonio entre hombres faltaría gracia, dulzura, amistad o podría faltar placer. Para otros, en una relación de conyugalidad entre hombres no había reciprocidad del placer ni estabilidad

\footnotetext{
17 Aún no se identifica al acto sexual con la identidad "homosexual" de la persona. De hecho, este término no existía ni tampoco había una denominación afirmativa para este tipo de prácticas como sí hay en la actualidad. Los antiguos tampoco diferenciaban entre homosexualidad y heterosexualidad, sino entre tipos de preferencias, actos y posiciones.
} 
de la pareja; las relaciones sexuales se impondrían por violencia, donde el sujeto pasivo sería blando y femenino, sentiría vergüenza y suscitaría desprecio. Pero también hubo quienes argumentaban que este tipo de uniones constituían un lazo espiritual y un intercambio recíproco más elevado que permitía acceder a una virtud acabada.

Como también observa Fone, hacia fines de la Antigüedad, las actitudes hacia los hombres que tienen relaciones con otros hombres variaron gracias al desmoronamiento del imperio greco-romano, a desastres naturales y al aumento del ascetismo promovido por filósofos, judíos y cristianos. Finalmente, con el establecimiento del imperio cristiano en Roma, se promovieron edictos que prohibían los actos homosexuales hacia fines del siglo IV. Para la Iglesia, dichas prácticas eran pecaminosas y antinaturales, y la historia de Sodoma no tardaría en respaldar dichas sentencias. Se recordará que en el relato Lot es un viajero que llega a la ciudad de Sodoma, donde ve a dos ángeles con forma de hombres y los recibe en su hogar. Los vecinos golpean su puerta y piden que los ángeles salgan para poder conocerlos; Lot se niega y los vecinos se ponen agresivos. Los ángeles, para castigarlos, los ciegan y luego incendian la ciudad. ${ }^{18}$

Aquí el autor insiste en que las interpretaciones que se han hecho del Antiguo Testamento fueron bastante convenientes a los intereses de los homofóbicos ya que él no encuentra rastros de actos o deseos homosexuales en el relato. Cree que la posible equivocación gira en torno a la utilización del verbo "conocer", que en una acepción bíblica puede significar "hacer el coito con" o "abusar de", pero también puede significar "llegar a familiarizarse con". Pero para Fone la historia de Sodoma es un relato sobre las obligaciones de hospitalidad con los extranjeros ya que encuentra indicios similares en otros pasajes de la Biblia. Es decir que el motivo por el cual hoy se emplea el término "sodomita" para denostar homosexuales en realidad carece de sustento en la medida de que el castigo que cayó sobre los ciudadanos de Sodoma (sodomitas) no fue causado por su interés por abusar sexualmente de otros hombres (los ángeles) sino por su falta de hospitalidad hacia los extranjeros: los ángeles y Lot. Por lo tanto, el disgusto divino poco tendría que ver con las prácticas homosexuales de los paganos. Fone dice que en ningún pasaje bíblico se alude a la historia de Sodoma para referirse a una relación homosexual y sin embargo se la utiliza constantemente como un símbolo general del mal, de perversión y de desviación.

18 La historia completa bien puede encontrarse en el libro de Fone (2008: 112-113) o en el Antiguo Testamento. 
Tampoco halla menciones que expresen el rechazo divino sobre la homosexualidad en el Nuevo Testamento, si bien encuentra pasajes que se puede interpretar que aluden a los actos homosexuales, como también puede comprenderse lo contrario. Para Fone, el cristianismo primitivo desaprueba las prácticas paganas por encontrarse ante creencias y doctrinas antagónicas que amenazaban la continuidad del imperio. Estas actividades incluían la promiscuidad, el adulterio, afeminamiento, el sexo en público, el bestialismo, la prostitución homosexual, la lujuria y la jactancia del placer.

La asociación entre sexo y moral y la condena religiosa de las conductas sexuales de los romanos fue útil para establecer su autoridad en un imperio donde varios ciudadanos creían en otros dioses. Ante las devastaciones causadas por las guerras, las plagas y las catástrofes naturales, la idea del disgusto divino por las prácticas homosexuales sirvió no solo para brindar una justificación a la sociedad sino también para justificar la propia aversión de los homófobos, como señala el autor. En otras palabras, lo que hoy conocemos como homofobia en ese entonces servía a los intereses geopolíticos e ideológicos de los sectores dominantes. Esta enfermedad innombrable atentaba contra la Iglesia, las tradiciones y el matrimonio, lo que se decía que conduciría al ocaso de la familia y de la sociedad tal como se las conocía.

Más adelante, en la Edad Media tras la caída del Imperio Romano de Occidente, Justiniano declaró que Constantinopla sería la nueva capital del Imperio "romano" de Oriente. El incipiente surgimiento de los Estado-Nación junto con la paulatina extensión de la injerencia de la Iglesia judeocristiana permitieron que se vincularan los actos de sodomía con la noción de pecado: se creía que representaban una traición a la ley divina y que debían ser castigados. En el Medioevo se asistió a las leyes más duras que buscaron sancionar y erradicar los actos entre personas del mismo sexo: los edictos justinianeos, la Lex Julia y las prohibiciones impuestas por el rey visigodo Egica y el rey Felipe IV de Francia.

En Occidente, el aumento del poder Papal con las Cruzadas favoreció la articulación entre Iglesia y los Estados, motivo por el cual la primera se encargó de determinar el castigo divino y el segundo, de su aplicación terrenal. Pero parecía ser que la homosexualidad era una plaga: encontraron hombres que tenían relaciones carnales con hombres hasta en el clero. Se emprendió una tarea de reforma interna y de purificación; se publicaron manuales de conducta para uso interno en los monasterios que abogaban por la abstinencia sexual y que instaban a omitir actos carnales con 
personas del mismo sexo, entre otras cosas. Así, la doctrina religiosa imperante buscó regular los comportamientos sexuales en un contexto donde veían que las cifras de hombres y mujeres que cometían actos abominables eran altas: había actos sodomitas por doquier y estos amenazaban el orden de lo establecido.

Y mientras los judeocristianos y luego los protestantes se preguntaban si los hombres tenían relaciones con hombres por una inclinación natural o por elección, disminuía la tolerancia hacia ellos y aumentaban las prohibiciones legales. Según Fone, aborrecían mucho más a los hombres que se acostaban con otros hombres por elección que a aquellos que no. Se condenaba la penetración anal, la masturbación mutua, la felación o el encuentro carnal con emisión de semen; estos actos eran punibles, si bien el castigo podía variar según la edad, la posición social y la reincidencia de los sujetos. Los castigos terrenales podían incluir excomulgación, destierro, latigazos, lapidaciones, encierro con ayuno o muerte en la horca o en la hoguera, que fue el castigo preferido para la Inquisición. ${ }^{19}$ Además, a los pecadores se les extraía su patrimonio y sus terrenos. En el plano espiritual, a algunos se les concedía el perdón si se arrepentían de su conducta y no la volvían a cometer, o si se sometían a la cura, que por lo general para los hombres era el matrimonio con una mujer. A los que no lo hacían, se les negaba el ingreso al cielo.

Asimismo, la acusación de sodomía, considerada una herejía, era bastante útil para los fines políticos, económicos y religiosos del Imperio Romano; ello quedó en evidencia con las Cruzadas ante el dominio musulmán en algunos territorios europeos y con la orden de los Templarios, un grupo que tenía más riquezas que todo el Imperio. En el caso de estos últimos, una vez que hubieron terminado su campaña en Jerusalén, se los condenó sin pruebas por herejía y sodomía. Luego de su juicio, se los torturó para que confesaran sus pecados y solo tres dijeron haber practicado sodomía, quienes antes de su ejecución en la hoguera se retractaron. Al respecto, el autor observa que a veces bastaba con acusar a una persona de realizar el pecado que ni se podía nombrar de lo abominable que era para que la enjuiciaran por desafiar la ley divina. Por lo tanto no hay certezas de si hubo tantos homosexuales como juicios registrados.

A comienzos de la Edad Moderna, los conquistadores europeos que llegaron a América se encontraron con comunidades en las que se aceptaban las relaciones entre personas del mismo sexo y en las que había hombres afeminados que tenían un lugar

19 El autor no puede precisar con exactitud cuántos hombres y mujeres fueron muertos en la hoguera ya que las actas eclesiásticas generalmente las quemaban con ellos. 
especial en su comunidad. Los colonos tomaron las inclinaciones de los americanos como excusa para eliminarlos: realizaron matanzas ejemplificadoras para evitar que se propagara el mal y que los demás habitantes supieran que esas prácticas no debían tolerarse. Las misiones cristianas, jesuíticas y puritanas acentuaron sus castigos para eliminar a las personas que cometían sodomía, palabra que cada vez más designaba a las relaciones sexuales entre personas del mismo sexo.

En Europa, el Renacimiento se encargó de identificar al acto de sodomía con la persona que cometía dicha acción: así se creó la figura del sodomita, de aquel que corrompe jóvenes, que es afeminado, desviado y, sobre todo, un criminal. Pero mientras los castigos se volvían más severos, hubo un aumento de la literatura que defendía las relaciones de amistad y camaradería entre hombres y que no recibió grandes resistencias por parte del pueblo. No obstante, varios ciudadanos seguían reaccionando con temor ante la creencia de que la homosexualidad era una pandemia europea, algo que combinaba prejuicios xenofóbicos con los homofóbicos y que, por ejemplo, los llevó a creer que la mayor cantidad de sodomitas vivía en Florencia en Italia y en Londres, Inglaterra.

A medida que pasaban los años, la paranoia y el pánico difundido por la amenaza de sodomitas crecían a la vez que se los perseguía y se los condenaba con pena de muerte. La prensa y la opinión pública no eran tolerantes con lo que parecía ser una subcultura de sodomitas: estos representan un peligro para el Estado. Y la incipiente ciencia moderna empezaba a plasmar sus prejuicios morales en el estudio de la sexualidad y a decir que los homosexuales eran "enfermos", "dementes" e "invertidos", y se los intenta "curar" con terapias de electroshock y otras medidas igual de invasivas. Por ello, y quizás como reacción, escritores e intelectuales publicaron numerosos escritos en defensa de la sodomía como una inclinación natural y como una identidad sexual legítima, a la vez que denunciaban los prejuicios y los peligros que estos representaban para los homosexuales.

Los desafíos contra las leyes antisodomitas ayudaron a que se despenalizara la sodomía en varios países europeos con la Ilustración y la Revolución francesa. La legislación inglesa abolió la pena de muerte pero conservó la sodomía como un crimen punible hasta 1965. Antes de esa fecha, el intento de llevar a cabo un acto sodomita también era un hecho criminal y un atentado contra el Estado que podía ser castigado con el sometimiento a trabajo forzado o a diez años de prisión. No obstante, varios escritores homosexuales europeos reivindicaron sus derechos sexuales llamando a 
resistir. Estos abogaban por su propia libertad, criticando la dictadura heterosexual impuesta por la ciencia con el aval estatal. Pero no lograron el efecto buscado ya que esto condujo a que se prohibieran y censuraran algunos de sus textos y a que decayera la opinión del público sobre este grupo.

En el siglo XX, tanto en Europa como en Estados Unidos existió literatura explícitamente homoerótica como también hubo una literatura homofóbica que perpetuaba los estereotipos predominantes. Lo mismo ocurriría en el teatro años más tarde. Lo cierto es que la cacería de homosexuales que se llevó a cabo en Estados Unidos a mediados de siglo junto con la extendida censura estatal y persecución policial condujo a que lentamente se conformaran movimientos de resistencia por los derechos de los homosexuales. La rebelión del bar Stonewall Inn en 1969, en donde personas LGBTIQ resistieron por tres días a una redrada policial antisodomita, llevó a que naciera el gay power y que comenzara a tomar forma el activismo gay de la década de 1970. Algunos de estos movimientos tendrían una vertiente asimilacionista en pos de la inclusión de los y las homosexuales en la sociedad; a los otros grupos los podríamos denominar "separatistas" ya que rechazaban la asimilación y celebraban la diferencia.

Rafael Mérida Jiménez (2009) brinda más información sobre esta porción de la historia del colectivo LGBTIQ al centrarse en dos hechos clave: la rebelión de Stonewall y la crisis del SIDA. El autor señala que la revuelta de Stonewall convocó a personas de distintas clases, razas y orígenes, a la vez que plasmó la participación de gays, lesbianas, transexuales y travestis en temáticas que poco tenían que ver con sus reivindicaciones como grupo. Iniciado por mujeres trans, este evento se vio favorecido por el clima de efervescencia política de la época. Sus antecedentes fueron los movimientos antibelicistas, las luchas organizadas a favor de los derechos de las mujeres y de los negros, los movimientos estudiantiles radicales y los activismos contraculturales. Otros antecedentes fueron el trabajo previo de organizaciones tales como Mattachine Society y Daughters of Bilitis, surgidos en la década de 1950, y las manifestaciones de la Homosexual League of New York contra los despidos de las Fuerzas Armadas estadounidenses y la denuncia de las East Coast Homophile Organizations contra las políticas discriminatorias gubernamentales de contratación. Todos grupos que habían tenido un rol activo en la denuncia de la homofobia imperante y la heterosexualidad compulsiva.

Stonewall contribuyó a que emergieran consignas más radicalizadas y que se visibilizaran nuevos protagonistas LGBTIQ. Así, en ese año surgió el Gay Liberation 
Front de Nueva York, para contrarrestar todas las injusticias económicas, raciales, genéricas y sexuales. También apareció la Liga Estudiantil Homófila en Columbia, el Grupo de Liberación Gay de Chicago, las Radicalesbians y movimientos y publicaciones por la liberación trans, como el grupo STAR (Street Transvestite Action Revolutionaries). En la década de 1970, surgió el colectivo Fag Rag en Boston, alcanzó mucha visibilidad el activista y político Harvey Milk, se realizó la manifestación de Christopher Street Liberation Day March (antesala de las marchas del "orgullo gay”) y el evento San Francisco Gay Freedom Day.

Tanto Fone como Mérida Jiménez coinciden en que las reivindicaciones del activismo LGBTIQ se vieron contrarrestadas por la ola de homofobia que devino con el “cáncer gay" o "peste rosa": la crisis del SIDA de los '80 constituyó un ataque moral, legal y cultural para frenar la revolución sexual. En respuesta a ello, nacieron organizaciones como ACT UP (AIDS Coalition To Unleash Power), Gay and Lesbian Alliance Against Defamation, National Gay and Task Force, Lesbian Avengers y el colectivo de Queers anónimos (más conocidos como Queer Nation). Ninguna de estas agrupaciones era idéntica pero tampoco perseguían propósitos muy distintos. De hecho, el teórico español señala que hay ciertas continuidades y rupturas entre los movimientos gays y lesbianos entre sí y con los queers, si bien desde luego también puede haber diferencias entre esos. Uno de los dilemas principales radica en la cuestión de la inclusión o en la separación de algunas personas, sea por su identidad de género o su orientación sexual, entre otras; pero el asunto más importante se relaciona con la disputa entre igualitaristas y los antiasimilacionistas. De hecho, en la década de 1990 muchos activistas optaron por la obtención de algunos derechos civiles y por la integración de los homosexuales en las estructuras de la sociedad heterosexista existentes, sin abogar por su transformación, tal como observaba Fone. Los segundos son los queers, quienes por su parte critican la normalización "heterogaylesbi", resaltan la diferencia e incluyen en su seno a todo tipo de marginados para combatir la homofobia y otros tipos de injusticias y violencias.

Paralelo a ello se empezó a consolidar literatura académica y no académica acerca de la homosexualidad en Estados Unidos y en Europa entre 1970 y 1990. En el caso de las esferas académicas, primero se habló de gay and lesbian studies pero paulatinamente algunos empezarían a hablar de "estudios queer". Si bien su institucionalización no ha sido inmediata debido a las resistencias en ciertos sectores (de nuevo, académicos y no académicos), han tenido una mayor profundización hacia fines 
del milenio a partir de publicaciones paradigmáticas de Judith Butler con El género en disputa y Cuerpos que importan, y con Epistemología del closet, de Eve Sedgwick. Algunos de los antecedentes inmediatos de lo que hoy denominamos como teorías o estudios queer aparecen en las obras de Adrienne Rich, que desde su feminismo lesbiano denunció la heterosexualidad compulsiva; Audre Lorde, que insertó en el debate teórico feminista la consideración de la clase y raza como factores igualmente opresivos para las mujeres; y Monique Wittig, quien desde el lesbianismo radical francés identificó la violencia opresora que ejercen los discursos heterosexistas en la sociedad toda.

Preciado (2009) también nos ayuda a caracterizar el período bisagra para la historia de la homosexualidad, entre Stonewall y la crisis del SIDA, pero él más bien sostiene que hay un siglo entero entre 1869 y 1969 que es aún más crítico para la historia de la homosexualidad: en 1869 el lenguaje médico-jurídico europeo por primera vez puso nombre a la oposición entre hetero y homosexualidad como lo normal y lo patológico; y luego, en 1969, se consolidaron los primeros movimientos por la liberación homosexual en la Europa y en los Estados Unidos post-Stonewall. Dice que en esos cien años se perfeccionaron las técnicas de exterminio de la diferencia a la vez que se exaltaban los valores de la familia blanca y heterosexual. Pero en ese período también hubo otras transformaciones socioculturales que antecedieron al surgimiento de los activismos gay y con ellos a los estudios gays y lesbianos, como por ejemplo las guerras mundiales, Hiroshima, Nagasaki y Auschwitz, el auge de la sociedad de masas y la creación del adolescente como futura figura política en Occidente, el franquismo en España, la guerra de Vietnam, el black power estadounidense, la descolonización de Argelia y los movimientos pacifistas y ambientalistas que rodearon a ese suceso, el hippismo y el Mayo Francés.

El fortalecimiento de las agrupaciones estudiantiles, intelectuales y obreras, más el distanciamiento que el movimiento viril de izquierda marcó con respecto a los maricas, las lesbianas, las travestis y los transexuales, condujo a que las personas LGBTIQ se unieran tras las filas de las agrupaciones feministas europeas. Pero el Movimiento de Liberación de Mujeres fue apropiado por un feminismo blanco y heterosexual que peleaba en contra de la dominación masculina y en pos de los derechos reproductivos de la mujer; así rápidamente excluyeron a las lesbianas, a las travestis y las trabajadoras sexuales, quienes en Estados Unidos empezaban a luchar contra el patriarcado y hacia la emancipación de las mujeres en el espacio público. Una vez más, 
el feminismo blanco heterosexual absorbió la protesta y la agrupación National Organization of Women excluyó a las minorías sexuales y políticas. El grupo Lavender Menace, conformado por lesbianas radicales, se separaron de las feministas en protesta a esta explícita escisión. También hubo otro movimiento feminista pro-aborto denominado Commando Saucisson (Comando Salchichón) por una manifestación en una conferencia en contra de un profesional antiaborto.

Preciado comenta que mientras algunas agrupaciones feministas excluían a las lesbianas, los homosexuales y las travestis recibían el mismo trato por parte de la extrema izquierda. En respuesta a esto, nació en 1971 el Frente Homosexual de Acción Revolucionaria en París para visibilizar a la disidencia sexual y para politizar la sexualidad distanciándose del ideal de las "buenas chicas" que proclamaba el feminismo y de los "buenos homosexuales" que defendían las pequeñas agrupaciones homófilas. Luego se unieron con los homosexuales y travestis del grupo Gazoline y fueron los primeros en emplear técnicas de teatralización paródica en el espacio público. En paralelo, nació en clandestinidad el Movimiento Español de Liberación Homosexual bajo la dictadura franquista y en respuesta a la represión homofóbica posterior a la sanción de la Ley de Peligrosidad y Rehabilitación Social. En 1972 surgió Gouines Rouges (Bolleras Rojas) en crítica a la lesbofobia y al falocentrismo de izquierda francés. En 1977 se hizo pública por primera vez la agrupación Frente de Liberación Gay de Cataluña, que se desprendió del grupo español ya nombrado. Estas fragmentaciones hicieron que aparecieran nuevos movimientos en los ' 80 y los '90 en Estados Unidos ante la crisis del SIDA y los discursos homofóbicos y eugenésicos que lo rodearon. Otras agrupaciones fueron Lesbian Avengers y Radical Fury, que se sumaron a la visibilización de los drag kings y las drag queens, de los trans y de los intersexuales. Así crecían las políticas de identidad homosexual a la vez que nacían las políticas abyectas o queer.

A esta reconstrucción histórica debemos agregar que según Fone la calidad de vida de los homosexuales ha mejorado en los últimos años. Sin embargo, aún hay muchos vestigios de homofobia por combatir. Varias agrupaciones religiosas aún consideran que la homosexualidad es un pecado; hay médicos y psicólogos que todavía creen que la homosexualidad es una enfermedad que hay que curar. Hay edictos policiales que proscriben las sexualidades no heterosexuales y que las declaran como peligrosas o ilegales, y aún hay muchos políticos y jueces que comparten esta perspectiva. También persisten los despidos por homosexualidad, la quita de subsidios a 
los enfermos con HIV/SIDA y las bajas por conductas indecorosas en las Fuerzas Armadas estadounidenses. Sobre este aspecto debemos aclarar que Fone aludía a la política de Don't Ask, Don't Tell (No preguntes, no digas), que desde 1993 permitió el ingreso de homosexuales en las fuerzas siempre y cuando no manifiesten conductas homosexuales; a fines de 2010 el presidente Barack Obama la dejó sin efecto. El autor también menciona la imposibilidad de contraer matrimonio u obtener reconocimiento legal por parte de parejas en concubinato en ese país, algo que se modificó en 2015 bajo el segundo mandato de Obama.

Fone sostiene que además de que existan derechos diferenciales que excluyen o perjudican a homosexuales, hay personas que toleran pero que no aceptan la diferencia. Esto lo percibe en la serie de contestaciones, violaciones, golpizas y asesinatos que hubo en la vía pública y en la vida privada en la década de 1990 y cuyas víctimas fueron personas LGBTIQ. Afirma que "la violencia antigay aumentó no sólo contra los hombres blancos gays, sino contra las lesbianas, los gays de color, y los gays menores de dieciocho y mayores de sesenta y cinco" (2008: 570). Sus victimarios son mayoritariamente hombres blancos, aunque se multiplicó el número de mujeres que atacan a lesbianas y hombres homosexuales. Concluye que la violencia homofóbica existe en todas partes y siempre que se considere a los homosexuales como ciudadanos de segunda clase la amenaza estará siempre latente.

Por su parte, el periodista Osvaldo Bazán (2010) observa que la violencia homofóbica también estaba y está presente en Argentina y opina que aquí la homosexualidad siempre fue un pecado nefando. $\mathrm{Y}$ al igual que Fone, nota que la acusación de sodomía fue conveniente para los intereses geopolíticos y económicos de los colonizadores en América Latina entre los siglos XV y XVI. Estos veían que las prácticas sodomíticas eran frecuentes entre los americanos, quienes además no veneraban a su mismo Dios. Es notoria la similitud con los relatos de los cristianos que nombramos anteriormente: como los nativos derrochaban semen en prácticas no procreativas e idolatraban a hombres afeminados, había que eliminarlos. La Inquisición había llegado al continente. Con la conquista rápidamente se extendió el miedo y la sanción hacia estos enemigos herejes de la religión, a aquellos sujetos socialmente aceptados antes de la llegada de los europeos.

La represión de la homosexualidad como pecado continuó en los siglos XVII y XVIII, en los que la Iglesia católica buscaba imponer la moral cristiana a la población nativa. Los pecados que recibían un castigo más severo eran los sexuales: las torturas 
eran públicas a fin de adoctrinar al resto e imponer el modelo heterosexual. La historia de Sodoma tampoco tardó en llegar a Argentina, si bien uno de sus correlatos regionales fue el mito de los gigantes de Patagones: esta especie se creía extinguida por culpa del castigo divino provocado por su extendida homosexualidad. Sin embargo, no hay registros ni de su existencia ni de muchas de las prácticas homoeróticas de la época, lo que sin duda dificulta cualquier proceso de reconstrucción histórica.

Hacia principios del siglo XIX, tras el fin de la Inquisición, el peso del cristianismo seguía intacto y la sodomía seguía siendo un pecado. Pero en el modelo de construcción del país también se vio la necesidad de criminalizar una práctica que se creía extendida: se hallaron vestigios de homosexuales en el Regimiento de Patricios y se vio amenazado el modelo de ciudadano masculino y viril que se quería para la Nación. Bazán encuentra un claro ejemplo de ello en El Matadero, de Esteban Echeverría, donde el torturado resguardaba su virginidad anal ante aquellos que querían torturarlo y penetrarlo con una mazorca. El primero hace lo imposible para evitar este acto violento hasta que muere (o se suicida) antes de que le quiten su masculinidad. Este relato no solo representaría el modelo de hombre argentino de los años siguientes sino que también violentaría a aquellos que no se adecúen a él.

Jorge Salessi (1995) agrega que en la segunda mitad del siglo XIX se consolidó un proyecto de reorganización liberal y nacional que se sirvió del higienismo y la ciencia en general para alcanzar un ideal de modernización y de progreso y luego para construir y excluir otredades. Para tal fin, en principio, se desarrollaron sistemas de circulación y provisión de agua potable y desagües de aguas servidas para eliminar desechos y evitar el crecimiento de focos infecciosos tras la epidemia de la fiebre amarilla que causó miles de muertes en 1871. También se reforzaron los mecanismos de vigilancia hacia la clase obrera migrante, así como también se fortaleció la burocracia estatal con el propósito de evitar la propagación de enfermedades. Dichos controles se centralizaron en Buenos Aires tras la federalización del país y la creación del puerto en esa región.

Bazán señala que se avanzó hacia una secularización del Estado con la Generación de la década de 1880. Se promovieron la Ley de Registro Civil, la Ley de Educación Común y la Ley de Matrimonio Civil. También se redactó y se difundió el Código Penal, que no hacía ninguna alusión a las relaciones homosexuales entre hombres adultos. Bazán sostiene que esto se debe a que Argentina quería atraer inmigrantes de ciertas nacionalidades europeas y negar la existencia de sodomitas era un 
paso importante. Pero también se lo atribuye a las influencias de la Ilustración y a la difusión que tuvo el rechazo del artículo 175 del Código Penal alemán, que hasta el año 1994 penaba las relaciones sexuales entre hombres. Además, se conoció que Kertbeny empleaba el término "homosexualidad" para hablar de sujetos que eran anormales por causas innatas; aquel creía que la ciencia debería ocuparse de ellos y no la ley. También menciona los aportes del abogado Karl Ulrich y su defensa del uranismo. Con todo, se empezó a pensar en las prácticas homosexuales como actos privados y no tanto como asuntos del Estado.

Sin embargo, los científicos higienistas hicieron usos políticos de sus proyectos sanitarios y crearon figuras de nuevos criminales que atentaban contra la salud pública, entre los que aparecían las prostitutas, los anarquistas y los homosexuales. La ciencia nuevamente se mezcló con la moral y también con la represión de la inversión sexual. De todos modos, esto no frenaba a los homosexuales de salir de yiro y encontrarse con soldados y marinos en el Bajo o en otros sitios de encuentro. Claro que si los encontraban, los detenían y los llevaban al Depósito de Contraventores "24 de noviembre" por ser masturbadores, onanistas o pederastas. Entre los delincuentes también había travestis y menores, quienes eran los que más preocupaban a los cientistas de la época. A las travestis y transexuales, aunque no se las denominara así, se las registraba y humillaba en los precintos, como también se las masculinizaba y denominaba por su nombre registral. Tal fue el caso de "Aurora" o de Manón". Los procedimientos en contra de los divergentes sexuales, como los nombra Bazán, fueron violentos, sus detenciones ilegales y sus aprisionamientos injustos.

Las razones detrás de la criminalización de la diferencia estaba en parte en la ciencia, quien intentaba delinear si la homosexualidad era una condición congénita o adquirida, para saber si se practicaba la homosexualidad por influencia del ambiente o por sugestión (los italianos, se decía, eran los que más sugestionaban a los muchachos argentinos). Pese a todo, las grietas en el sistema permitieron que algunos se burlaran de él. Bazán cuenta el caso de "La bella Otero", quien publicó su autobiografía en revistas científicas estatales gracias a las entrevistas que le realizó el psicólogo Francisco De Veyga, siendo la primera travesti que difundió los registros de la vida homosexual local en un medio nacional. Y así como se propagaba su voz, también se creía que se extendía la homosexualidad: se veía como "caldos de cultivo" de homosexuales a los internados religiosos y al Ejército. No obstante lo anterior, se volvieron a estrechar lazos con la Iglesia hacia inicios del siglo XX. 
Entretanto, se veía con temor a las mujeres masculinas y a los hombres femeninos, por lo que se intensificó la cacería hacia los delincuentes, les inventarían contravenciones, los detendrían y los declararían incapacitados civiles o los recluirían de por vida. El miedo aumentaba ya que la Policía podía detener a cualquiera que se creyera que tenía una patología sexual. La obra de teatro "Los invertidos", de José González Castillo, luego censurada, parecía mostrar que la única escapatoria que tenían los homosexuales era el suicidio. En la literatura de la época aparecían personajes homosexuales pero siempre con una carga homofóbica que no los conducía a un final más trágico que el que encontraban fuera de la ficción. Por otra parte, la prensa los describía con asco, los nombraba peyorativamente y desde la psiquiatría se instauraba la heterosexualidad como lo normal. La homosexualidad entonces pasaba a ser tratada como un tema de profilaxis social.

De la xenofobia higienista se pasó a una de tinte criminal: desde las Ciencias Sociales finiseculares y la criminología, se veía con temor a los viajeros que podían tener enfermedades físicas, morales y psicológicas que pondrían en riesgo la salud del resto de la sociedad. Salessi dice que en una clara estrategia de control se señaló primero a los socialistas y anarquistas europeos que con algunas mujeres constituyeron los primeros movimientos obreros. Inmediatamente, en 1902 se sancionó la Ley de Residencia y luego la Ley de Defensa Social en 1910 para hacer frente a estos inmigrantes y descartar a los que presentaran una amenaza para la estabilidad nacional. En simultáneo, se dio impulso a la medicina legal y se crearon institutos de reclusión de sospechosos y delincuentes en manicomios y cárceles. Las figuras que representaban a los criminales como anormales se utilizaban para demarcar las normas de la respetabilidad burguesa nacional, por lo que se fomentó el crecimiento de las fuerzas policiales para extender su vigilancia sobre toda la ciudad.

El investigador también observa que el travestismo y la feminidad masculina estaban mal vistos al igual que la de paiderastia pasiva, ya que se consideraba que el deseo por ocupar una posición receptiva era no solo antinatural sino también algo degenerativo para los hombres. El estigma se debía en parte a que predominaba la percepción higienista, que entendía al ano como una cloaca que portaba materia fecal y, con ella, enfermedades infecciosas. Por otra parte, dice que no estaba tan mal vista la posición contraria, la de los seductores activos, aunque sí se la sancionó en la medida de que se creía que eran los causantes de la inversión de los hombres pasivos. Agrega que, en el caso de las mujeres, se veía como amenaza a aquellas que no se adecuaban al 
modelo de mujer de ese entonces; lo mismo con aquellas que ocupaban los cargos laborales tradicionalmente reservados para los hombres. Sin embargo, estas no provocaron tantos temores como lo hicieron los hombres que estaban sexualmente atraídos hacia otros hombres ni las personas que mostraban los límites de los binarismos de género.

Salessi afirma que la literatura científica de la época presentaba a estos sujetos como invertidos sexuales, peligrosos y alienados y que se los observaba y describía cautelosamente para encontrar los rasgos físicos y las marcas observables en sus cuerpo que dieran cuenta de su sodomía, algo que hicieron también los médicos forenses con los cadáveres de los delincuentes en general. Pero la preocupación de estos moralistas ante la creciente horda de homosexuales era saber si la inversión sexual era adquirida o congénita, latente o patente, quién ocupaba el rol insertivo y receptivo y de qué país provenían los "seductores". Esto sucedió a raíz de la creencia popular de que algunas nacionalidades extranjeras eran más proclives a la homosexualidad que otras: se sospechaba de los alemanes de clase alta y de los italianos pederastas de clase baja. Los síntomas de degeneración escapaban a lo que querían para el país los políticos y científicos del siglo anterior y ello quedó en evidencia con las noticias sobre los escándalos entre militares argentinos y alemanes. Ello pareció confirmar estas presunciones y provocaron ciertas ansiedades a principios del siglo XX.

En ese entonces se extendió la idea de que la presencia de los anormales era común en todas las esferas de la sociedad y que circulaban por flujos ocultos, contaminando todos los espacios públicos y privados. La "evidencia científica" mostraba una tipificación de estos sujetos: se decía que eran invertidos profesionales que ejercían la prostitución o que trabajaban como peluqueros de las mujeres de los sectores marginales o bien como sirvientes en hogares dentro de las clases altas. O que se movían por los bajos fondos y creaban reuniones entre ellos, en las que realizaban casamientos ficticios y se cambiaban el nombre por uno del sexo opuesto.

Bazán remarca que la violencia contra homosexuales aumentó hacia la década de 1930 y 1940. En 1932 se impuso un edicto policial que sancionaba a los sodomitas que estaban en compañía de un menor. En 1936 se promulgó la Ley de Profilaxis Social que prohibió los establecimientos prostibularios. Luego le siguió el decreto 10.868/46, que penalizaba la pederastia, contradiciendo al Código Penal. Este decreto contenía varios artículos que serían utilizados para castigar a homosexuales como la contravención por “Escándalos”, por "Bailes públicos”, por "Exhibirse en la vía pública o lugares públicos 
vestidos o disfrazados con ropas del sexo contrario" o por "Incitar u ofrecerse públicamente al acto carnal, sin distinción de sexos" $(2010: 218){ }^{20}$ De este modo, se profundizó la creencia de que los homosexuales eran invertidos apátridas vinculados con el comunismo, con la abolición de la religión, con la desintegración de la Patria y de la familia. La homosexualidad era un pecado, un delito y un vicio y, como tal, debía desaparecer.

Así, los homosexuales no podían verse en bares ni pasear con sobrinos o parientes menores, ni votar, ni integrar el Ejército ni tener ningún tipo de visibilidad. Los perseguía el Estado mientras que los medios de comunicación divulgaban sus nombres. El pánico hacia los homosexuales se multiplicó nuevamente en 1942 con el escándalo del Colegio Militar de la Nación en el que se supo que se hacían reuniones entre hombres y donde se encontraron fotografías de cadetes desnudos. E incluso desde la clandestinidad, los homosexuales no desaparecían. Se encontraban en los baños públicos de los trenes y desarrollaban textos propios y un argot para ellos solos. Y las regulaciones aumentaban ante esta calamitosa y contagiosa enfermedad y se llenaba de homosexuales y travestis la cárcel de Villa Devoto.

Por ello, en 1954 se reformó la Ley de Profilaxis Social ya que se creía que los hombres tenían sexo con hombres por falta de oportunidades con mujeres, o eso es lo que se dijo. Como indican Karina Ramacciotti y Adriana Valobra (2014), si bien esta reforma buscaba imponer una moral sexual para así mantener la masculinidad heterosexual y limitar las supuestas perversiones sexuales, tuvo consecuencias no deseadas: una de ellas fue la homosexualidad femenina, según los médicos de la época. Pero las safistas se mantuvieron en el closet ante las posibles sanciones sociales y el temor a las denuncias y a los encierros médico-psiquiátricos. Además, un año antes de la modificación de la ley, se había instaurado el primer Departamento Sexológico del país. Su responsable, el Dr. José Opizzo, fue el impulsor de una terapéutica para tratar

\footnotetext{
20 Estos decretos estuvieron vigentes hasta 1994 y fueron sustituidos por los códigos de convivencia urbana, por ejemplo en la Ciudad Autónoma de Buenos Aires. Con nuevos nombres o tipologías, se sigue criminalizando el oferta (y la demanda) sexual y reprimiendo sobre todo a las mujeres trans y travestis. A su vez, hoy se utiliza la Ley de Estupefacientes para continuar con sus detenciones. El 7 de octubre de 2016 distintas organizaciones presentaron en el Congreso Nacional un proyecto de ley nacional de reparación histórica a víctimas de violencia institucional con el fin de indemnizar a las personas trans y travestis que hayan sufrido torturas, vejaciones y detenciones ilegales por parte de las fuerzas policiales y militares. Se profundiza sobre el tema en: ESPAÑA, P. (7 de octubre de 2016) "Nunca más", Página/12. Disponible en http://www.pagina12.com.ar/diario/suplementos/soy/1-4782-2016-10-08.html [Consultado el 22 de octubre de 2016]
} 
las enfermedades y patologías sexuales y readaptar a los desviados para llegar a la normalidad (Maffía, 2014).

En la década de 1960 y 1970 hubo una creciente resistencia a esta moral sexual opresora. Bazán encuentra que se denunciaban los atisbos de la homofobia en la Revista Sur y Contorno, mientras que la Editorial Tirso publicaba libros de temática homosexual; allí se enunciaban los prejuicios para luego destruirlos. La rebelión de Stonewall de 1969 también fortaleció en los '70 a los movimientos de activismo en Argentina, específicamente a la agrupación Nuestro Mundo, Bandera Negra, el movimiento lesbiano Safo, el grupo católico Emanuel y el Frente de Liberación Homosexual. Sin embargo, la represión homofóbica siguió en alza, por lo que se escindieron y se disolvieron algunos de estos grupos.

Néstor Perlongher (2008) sitúa la aparición de estas agrupaciones inspiradas en el movimiento gay estadounidense en un contexto en el que el país estaba fuertemente politizado y donde había grupos de estudiantes universitarios y de militantes de izquierda realizando protestas y prácticas contestatarias; algunos de ellos se incorporaron al Frente. Ellos creían en la posibilidad de llevar a cabo una revolución que transformara las estructuras sociales vigentes; defendían la necesidad de derogar los edictos antihomosexuales, hacer cesar la represión policial y articular su trabajo con las feministas y con movimientos por la "liberación nacional y social”. Así, el Frente quedó conformado por varias organizaciones y nuclea a Safo, Emanuel, Eros, Nuestro Mundo, Bandera Negra y Católicos Homosexuales Argentinos, entre otros.

Perlongher agrega que el Frente tenía la tarea de politizar y concientizar a los homosexuales para tomar conciencia de su opresión; se repartían volantes y se hacían pintadas en la vía pública. Su intervención política aumentó con el triunfo del peronismo pero su organización permaneció en la clandestinidad en tanto seguían las razzias policiales y las detenciones de homosexuales. Pero los peronistas negaron la inclusión de homosexuales en sus filas, por los que miembros del Frente quisieron acercarse a la izquierda: solo pocos trotskistas y anarquistas los aceptaron. Tampoco recibieron atención por parte de la comunidad homosexual porteña, que parecía ser indiferente a las reivindicaciones de la agrupación. Pese a todo, en 1973 el Frente publicó un número del periódico Homosexuales y luego editó la revista Somos, donde se tematizaba el afeminamiento homosexual como superación de la opresión machista y también el travestismo, si bien hubo opiniones dispares ante este tópico. 
En esos años, el Frente estrechó vínculos con las agrupaciones feministas Unión Feminista Argentina y Movimiento de Liberación Femenina. Juntos crearon el Grupo de Política Sexual en pos de la liberación sexual. Se terminaron identificando como un movimiento anticapitalista y antiimperialista que buscaba la liberación de la mujer y de los hombres ante la dominación masculina; subrayaban la necesidad de subvertir las estructuras ideológicas opresoras como forma de avanzar hacia una revolución transformadora. La fascistización de la política nacional no contribuyó a que esta propuesta tuviera éxito. Las represiones aumentaron, el Papa Pablo VI demonizó la homosexualidad y los medios de comunicación abiertamente llamaron a linchar homosexuales, como hizo el semanario El Caudillo en 1975. La dictadura militar de Videla recrudeció la persecución homofóbica y el Frente decidió disolverse en 1976.

Retomando a Bazán, él indica que con el Proceso de Organización Nacional, varios activistas emprenderían su exilio, se esconderían en la clandestinidad o se escaparían a las islas de Tigre como espacio predilecto de socialización. Ello a pesar de que en paralelo, en 1973, la Asociación de Psiquiatría de Estados Unidos declaró que la homosexualidad no era una enfermedad, algo con lo que acordó la Organización Mundial de la Salud en $1974 .^{21}$ La restauración de la democracia en Argentina rápidamente demostró que el activismo gay tendría que establecerse como movimiento autónomo y prescindir de los lazos con los partidos políticos, en su mayoría homofóbicos. Para el autor, la vuelta a democracia no dio lugar a una inmediata inclusión de las personas LGBTIQ. De hecho, no hubo registros oficiales sobre cuántas personas homosexuales o trans fueron asesinadas o desaparecidas por la última dictadura militar, o quizás hubo un borramiento de las identidades de género y de las orientaciones sexoafectivas de las víctimas de la última dictadura. Además, siguieron vigentes las razzias, las persecuciones policiales, las extorsiones, las detenciones ilegales y las torturas contra el colectivo. Este proceso de transición democrática fue más bien paulatino y se vio favorecido por los cambios en las estrategias de los militantes: si en los sesenta y los setenta se había puesto el foco en la revolución sexual, en los ochenta se pasaría a adoptar una política de derechos humanos. Y luego, en los noventa y el nuevo milenio, la bandera sería en defensa de la diversidad sexual y de la reivindicación de la diferencia (Brown, 2002; Rapisardi, 2008).

\footnotetext{
${ }^{21}$ Este organismo afirmó que la homosexualidad no era una condición patológica en 1992.
} 
La crisis del SIDA, desatada en Argentina en 1984, implicaría algunos retrocesos en materia de tolerancia y aceptación: Bazán afirma que fue la excusa perfecta para hacer una campaña moral a favor de la abstinencia y en contra de los homosexuales. Se creía que los grupos de riesgo eran los hombres homosexuales como parte de un castigo moral ya que todo lo asociado a ellos era malo y contagioso. En este sentido, Facundo Saxe afirma que los primeros casos de HIV/SIDA que se conocieron en Estados Unidos datan de principios de la década de 1960 y que, finalmente, el grupo de riesgo quedó conformado por lo que se conoce como las 4-H: homosexuales, haitianos, hemofílicos y adictos a la heroína $(2013: 26) .{ }^{22}$ La paranoia sobre las prácticas de riesgo y los miedos en materia de salud no tardaron en llegar, hecho que volvió a estigmatizar a los homosexuales como enfermos y a exacerbar la discriminación en su contra.

Las agrupaciones de gays y lesbianas abandonaron la retórica de la revolución y la liberación sexual en pos de una estrategia de visibilización, de concientización y de sensibilización para lograr la transformación sociocultural (Encarnación, 2013). En consecuencia, aumentaron su participación en distintas protestas sociales por el castigo a los genocidas militares o por otras causas de derechos humanos y comenzaron a abrirse paso en los medios de comunicación. No obstante, estos usaban la figura del homosexual para reírse de ella y para ridiculizar al colectivo, como señala Bazán respecto a la década del ' 80 . En ese contexto, existían normativas sobre los medios de comunicación que establecían que la televisión debía abstenerse de exaltar el desvío sexual o el erotismo. Por lo tanto, las actuaciones reforzaban estereotipos y prejuicios de forma banal en vez de denunciarlos. Pero también aumentó la visibilidad de las personas LGBTIQ en algunos medios de comunicación, no sin resistencias por parte de la Iglesia. Además, empezaron a haber obras de teatro con menos carga de prejuicios, después de la época dorada que tuvo el teatro disidente entre 1930 y 1950 pese a la persecución policial. En paralelo, nació la revista Cerdos y Peces y aparecieron algunas performances en el mundo del espectáculo que intentaban romper con los modelos culturales establecidos. Y en 1984 surgió la Comunidad Homosexual Argentina, que fue la primera agrupación LGBTIQ en recibir personería jurídica tras varios años de espera recién en 1992.

22 Tanto en Estados Unidos como en Argentina, las organizaciones civiles por los derechos de las personas LGBTIQ fueron propulsoras de campañas de concientización sobre cuidados y formas de transmisión del virus. Asimismo, fueron los responsables de canalizar las demandas de la colectividad hacia gobiernos en cuyas agendas no siempre aparecían los damnificados. 
Asimismo, en los '90 emergieron los primeros movimientos por las personas trans: la Asociación Lucha por la Identidad Travesti-Transexual (ALITT) y la Asociación Travestis Argentinas (ATA); la última cambió su nombre a Asociación Travestis Transexuales Argentinas (ATTA) en 1996 y de nuevo en 2001 por Asociación Travestis Transexuales Transgéneros Argentinas (ATTTA). Denuncia Bazán que las personas trans son las más perjudicadas en el sistema penal por la severidad de los edictos policiales en su contra y por la carga de prejuicios de los oficiales que abusan de ellas o las asesinan en comisarías. Y tal como demuestra la Comunidad Homosexual Argentina en los informes anuales sobre violaciones a los Derechos Humanos y civiles en la República Argentina basadas en la orientación sexual de las personas y de las personas que viven con VIH/SIDA, no se profundiza en la investigación de los crímenes cometidos contra homosexuales y travestis. Y como generalmente se los cataloga como "robo", no se les otorga el rótulo de "crimen de odio". Por lo tanto, no se reconoce el agravante de un delito que se cometió con motivo de rechazo por la presunta orientación sexual o expresión o identidad de género de la víctima.

En la década de los noventa se asistió a otros cambios: en junio de 1992 aconteció la I Marcha del Orgullo Lésbico-Gay en el país. A partir de 1994 el movimiento trans se integró a estos eventos a partir de la III Marcha del Orgullo LGBTIQ; su participación sería constante en los años siguientes. En esa época creció la presencia de homosexuales, transformistas y travestis en los medios de comunicación, como el caso de Antonio Gasalla, Urdapilleta, Tortonese, Cris Miró y Florencia de la V. Hubo más programas y películas que los representaban en la televisión y en el cine nacional. Esta tendencia se profundizó en el nuevo milenio con la aparición pública de otros homosexuales, como Fernando Peña, Gastón Trezeguet y Juan Castro y de un bisexual, Julio Bocca, para nombrar algunos.

Luego, en 2001 la Comunidad Homosexual Argentina impulsó un proyecto de ley por la unión civil en la Ciudad Autónoma de Buenos Aires para dar reconocimiento estatal a las personas del mismo sexo que convivían juntas. Los medios de comunicación se referían a la ley como "casamiento gay" mientras que la Iglesia se resistía y recordaba que la homosexualidad era una desviación. La propuesta obtuvo tratamiento en la Legislatura porteña a finales del 2002 después de varias barreras burocráticas. Llegada la fecha, una amenaza de bomba demoró el procedimiento de votación. Después hubo confrontaciones entre militantes católicos y militantes homosexuales. Finalmente la ley se aprobó y se promulgó el 17 de enero de 2003; un 
proceso similar ocurrió en Río Negro el 11 de abril del mismo año. Bazán omite el dato pero también se aprueba este proyecto en Villa Carlos Paz el 23 de noviembre 2007 y en Río Cuarto el 7 de mayo de 2009 (provincia de Córdoba). El periodista comenta que con estas transformaciones Argentina pasó a ser un país abierto al turismo gay internacional y a los dólares y euros que vienen con él. Esto dio impulso al nacimiento de un mercado orientado a los homosexuales que crearía hoteles, saunas, boliches, clases de tango, librerías, que, no obstante, no reflejarían la multiplicidad y diversidad de la comunidad argentina. El nuevo interrogante es, dice, "si el camino es la integración en donde la diferencia no cuente o la diferencia como rasgo característico para la integración" (2010: 457), una cuestión que sigue muy presente en los debates entre diferentes grupos de activistas.

Mucho antes que en Argentina, en España se promulgó la ley que permite los matrimonios civiles entre personas del mismo sexo y la adopción compartida en 2005; Canadá, Holanda y Bélgica lo habían hecho primero. En Argentina en parte se siguió el ejemplo español y se delineó un plan de acción para ganar los mismos derechos: se creó una estrategia por vía judicial, que consiste en pedir turno en un Registro Civil para contraer matrimonio y presentar un recurso de amparo (o más) ante la negativa; y la vía legislativa, que consistía en la presentación del proyecto de ley en el Congreso. La primera no siempre fue exitosa, pero algunas parejas sí pudieron casarse, como Alex Freyre y José Di Bello en Río Negro en 2009 después de que se les negaran turnos para contraer matrimonio en Buenos Aires. Con respecto a la vía legislativa, el 4 de mayo de 2010 se sesionó en la Cámara Diputados del Congreso Nacional y se aprobó sin modificaciones el proyecto de ley por el matrimonio igualitario y adopción por parte de personas del mismo sexo presentado por varias organizaciones civiles.

El autor sostiene que a partir de esa fecha y en los 69 días previos al tratamiento en el Senado, que sería el 14 de julio, todos hablaron sobre el matrimonio igualitario. Según Bazán, en esos días hubo un cambio cultural que generó un debate nunca antes visto sobre un asunto vinculado a esta minoría sexual. Todos tuvieron que formar una opinión respecto a un tema que se instaló en todos los espacios de la vida cotidiana. El tópico suscitaba grandes adhesiones y grandes rechazos. Las encuestas indicaban que el $81 \%$ de la población censada estaba a favor de la ley. En ese período hubo numerosas marchas y contramarchas en distintas partes del país, que se convocaban y se organizaban por las redes sociales. Una de ellas tuvo lugar en la plaza frente al Congreso el 13 de julio, un día antes la sesión parlamentaria. Fue una marcha en 
rechazo por la ley y fue convocada por distintas facciones de la Iglesia Católica y por sectores de otras religiones cuyos lemas fueron "Familia hay una sola" y "Los chicos tenemos derecho a una mamá y un papá”. Algunos recuerdan este evento por el color naranja de las prendas que vestían los manifestantes. Y según Bazán, esa protesta contaba el aval del ex cardenal Jorge Bergoglio, el actual Papa Francisco, y de autoridades de distintas agrupaciones religiosas.

Pese a todo, la ley tuvo su tratamiento y su sanción el 15 de julio a las 4 de la madrugada con personas expectantes que lo miraban por televisión, que lo seguían por las redes sociales o que esperaban en la Plaza del Congreso o en bares aledaños; los representantes de agrupaciones por los derechos LGBTIQ y partidos políticos estaban presentes. En el proceso de debate parlamentario se escucharon muchos argumentos en contra: que el matrimonio es entre un hombre y una mujer, que no se puede equiparar lo que no es igual, que no es discriminar pero que mejor es ir por una unión civil, que lo que Dios manda y lo que está en la naturaleza es la procreación, que la homosexualidad no es normal, que con esta ley se discrimina a los heterosexuales y al matrimonio, que la prioridad es garantizar los derechos humanos de los niños, que los chicos tienen derecho a tener una mamá y un papá, que solo ocho países permitían el matrimonio entre personas del mismo sexo (en ese entonces), que es el fin de la familia, que cómo le explican a sus hijos sobre educación sexual y sobre lo que está bien y lo que está mal, que todo es un manejo político de Cristina Fernández de Kirchner (presidenta en ese entonces) en contra de la Iglesia, entre otras. Pese a todo, la ley se aprobó con 33 votos a favor, 27 en contra, 3 abstinencias y 9 ausencias, y se la promulgó el 21 de julio.

Luego le siguió la Ley de Identidad de Género, que se sancionó el 9 de mayo de 2012 con 176 votos a favor, 17 en contra y 7 abstenciones. Ella habilita el reconocimiento legal de la identidad de género de las personas. Por su parte, el decreto $N^{\circ}$ 903/2015, publicado en el Boletín Oficial de la Nación el 29 de mayo de ese año, impulsó la reglamentación del artículo 11 de la última ley para garantizar que las personas trans tengan acceso gratuito a intervenciones quirúrgicas totales o parciales y a tratamientos hormonales y transfiere su cumplimiento al Ministerio de Salud de la Nación. ${ }^{23}$ Ahora bien, podría pensarse que las leyes de 2010 y 2012 son modos de reconocer las diferencias sin pretender homogeneizarlas en ningún aspecto dado que

\footnotetext{
${ }^{23}$ No es el caso en Argentina, pero legislaciones en otros países también obligan a las personas trans a cumplir un año presentándose públicamente con su género autopercibido por un año y a obtener autorización psicológica y médica antes de atravesar procedimientos hormonales y quirúrgicos para otorgar la posibilidad de acceder al cambio registral.
} 
subrayaron y valoraron positivamente las diferencias y que modificaron y actualizaron un aparato legislativo que excluía a las minorías y que las invisibilizaba por completo.

Sin embargo, y sin dejar de valorar los avances alcanzados, es necesario indicar que detrás de cada norma existen sentidos hegemónicos y normalizadores de representar a la diversidad y disidencia sexual gracias a los cuales las personas trans deben optar por delimitar de su identidad de género solo detrás de la categoría "hombre" o "mujer", excluyendo otras alternativas posibles. Por lo tanto, siguiendo a Charles Taylor (1993), sería menester hablar de un falso reconocimiento de la diferencia dado que estas leyes, si bien necesarias para algunos, no contemplan la pluralidad de narrativas, identidades y prácticas afectivas y deseantes de las personas LGBTIQ en su totalidad. Estas leyes refuerzan no solo el binario hombre/mujer sino también la idea de familia monogámica con descendencia procreativa o adoptiva. No legislan sobre la discriminación contra las personas LGBTIQ ni ponen fin a las intervenciones no consensuadas sobre los cuerpos de bebés intersexuales cuyos genitales no se adecúan a los protocolos médicos de las genitalidades "normales” (Maffía y Cabral, 2009).

Para finalizar, como vimos hasta aquí, en la Antigüedad las prácticas sexuales entre personas del mismo sexo contaban con mayor aceptación en la cultura griega y romana que en los tiempos que le siguieron. Hacia fines de dicho período y comienzos de la Edad Media, los judeocristianos convirtieron a la homosexualidad en pecado al asociar la historia bíblica de la destrucción de Sodoma a la figura que crearon, la sodomía, y luego a otra, la de herejía. Esta persecución religiosa se sumó a la estatal, que criminalizó y castigó los actos sodomitas con penas severas, como excomunión y muerte en la hoguera. La ciencia moderna y más adelante los medios de comunicación hegemónicos contribuyeron a consolidar y a difundir la idea de que los homosexuales eran enfermos que podían contagiar al resto de la población y subvertir el orden de lo establecido; gracias a esto, cotidianamente se miraba con temor a los hombres femeninos y a las mujeres masculinas. Sin embargo, los espacios que se utilizaron en detrimento de las personas LGBTIQ fueron los mismos que ellas emplearon para resistir, dar a conocer su voz y reclamar por los derechos que les fueron negados.

En Argentina, los movimientos de las minorías sexuales se articularon en torno a sus diferencias y contradicciones (y a partir de ellas) en el intento por desmantelar las distintas modalidades que adquiere la violencia y en la lucha contra los mecanismos desigualatorios e injustos de distribución de bienes materiales y simbólicos, incluido pero no limitado a la lucha por la representación y el reclamo contra la falta de acceso a 
los derechos (Forastelli, 2007). Para alcanzar este objetivo, ahora deben llevar adelante políticas afirmativas y políticas transformativas de las relaciones económicas y simbólicas a través de un nuevo proyecto político democrático con el propósito de reconocer las heterogeneidades, sin eliminar la alteridad y renegociando a su vez las formas de copresencia ciudadana (Rapisardi y Bellucci, 2001). En este orden de cosas, las iniciativas impulsadas por las diferentes personas que integran el colectivo LGBTIQ no son siempre similares entre sí pero debieran tener como denominador común la búsqueda por construir una sociedad igualitaria que no propicie nuevos modos de desigualación. La posibilidad de articular sus demandas, con lo variables y contradictorias que son entre sí, ayudaría a avanzar hacia la promoción de políticas de reconocimiento para construir espacios más habitables y mejorar las condiciones de vida de todos. La (seudo) igualdad formal actual podría mejorarse con acciones e iniciativas que tiendan a revertir las formas de menosprecio e irrespeto cultural contra la población LGBTIQ, como se hizo (no sin discrepancias) con la redacción y presentación de proyectos de ley para la actualización de la Ley Antidiscriminatoria.

Si hay una conclusión que puede extraerse de los textos reseñados hasta aquí es que las historias de las sexualidades minorizadas son historias de injusticias. En gran parte, ellas estuvieron y están atravesadas por una mirada estigmatizante y peyorativa, comúnmente denominada "homofobia". No obstante, como señala Fone, sería más preciso hablar en plural de fobias $\mathrm{u}$ odios dirigidos a personas con una orientación sexual y/o una identidad y expresión de género no normativa. ${ }^{24}$ Aquí continuaremos empleando la palabra "homofobia" para los fines prácticos de analizar y reflexionar en torno a las posturas que sistemáticamente discriminan y violentan a los disidentes sexogenéricos y por considerar que es la que más se utiliza en el lenguaje ordinario en este país y en otras partes del mundo. En este texto, entonces, pasaría a significar algo que más se asemeja a una homobilesbotransfobia, a una aversión hacia lo queer. Esta denominación abarca las formas de rechazo multiforme de las identidades, expresiones, orientaciones, prácticas, subjetividades y corporalidades no normativas y que afectan a las personas que presentan rasgos, gustos o intereses que no se condicen con lo que las ideologías dominantes conciben como "normal".

\footnotetext{
${ }^{24}$ Algunos activistas rechazan los términos "homofobia" o "transfobia" porque no es una enfermedad ni una patología ni un miedo irracional que habilita a las personas a discriminar. Creen que esto puede llevar a justificar a quienes en realidad fueron educados o que aprendieron a odiar a las personas por su orientación sexoafectiva o su identidad de género.
} 
Sabemos que no son iguales todas las -fobias (o mejor dicho, los odios) que obedecen a matrices de pensamiento homofóbicas y cisheteropatriarcales que violentan a aquellas personas con identidades, cuerpos, deseos y expresiones disidentes. La discriminación en su contra podía encrudecerse o reducirse según la intersección con factores como la orientación sexoafectiva, la identidad y expresión de género, la religión, raza, etnia, color de piel, edad, clase, tamaño, discapacidad, carga seropositiva, antecedentes penales, nacionalidad y condición migratoria, entre otras. Por ejemplo, la transfobia, a veces reducida a travestofobia, está provocando que año a año en Argentina aumenten las cifras de asesinatos a mujeres trans, especialmente las trabajadoras sexuales, mientras que no ocurre lo mismo con otros grupos de individuos que se reconocen como parte del colectivo LGBTIQ. A ellas se las persigue y se las criminaliza por la presunción de venta de estupefacientes, oferta sexual y escándalos en la vía pública. Y una vez que son detenidas, son sometidas a humillaciones, golpizas y abusos sexuales por parte de las fuerzas policiales, que rara vez serán denunciadas por a las graves consecuencias que pueden sufrir si denuncian a los agentes de seguridad (Bazán, 2010; Berkins, 2009; CIDH, 2015b). Más aún, a ellas se las sigue representando en la televisión abierta de maneras estereotipadas, estigmatizantes, ridiculizadoras y burlescas en tanto se las muestra como prostitutas o delincuentes, mientras que sí mejoró el tratamiento que se le da al resto de la comunidad de diversidad sexual desde la sanción de la Ley de Matrimonio Igualitario y la Ley de Identidad de Género (Pelazas, 2016).

En suma, la historia de estos movimientos muestra que queda un largo camino por recorrer dado que pese a las transformaciones legislativas recientes no han cesado los actos discriminatorios y otros actos violentos propiciados en su contra. No solo siguen habiendo casos de violencia en la que se humilla o se daña a las personas por su orientación sexual y su expresión e identidad de género sino que también falta la actualización de la Ley Antidiscriminatoria y falta que se acabe con la violencia negligencia estatal que es responsable del desfinanciamiento de programas de salud, del INADI y del Instituto Nacional de las Mujeres; de la falta de stock de preservativos y de antirretrovirales, de la falta de financiamiento integral del bachillerato popular trans "Mocha Celis", de la falta de implementación de la ley de cupo laboral trans en la provincia de Buenos Aires y de la falta de resolución ante las trabas impuestas por obras sociales y prepagas a nivel nacional que no permiten garantizar la cobertura de los 
procedimientos quirúrgicos y hormonales previstos por la Ley de Identidad de Género

(Gutiérrez, 2016). En definitiva, hay mucho por hacer. ${ }^{25}$

\footnotetext{
${ }^{25}$ Para continuar ilustrando nuestro punto, recordemos que a fines de agosto de 2016 echaron a una pareja de mujeres del bar porteño La Biela por demostrarse afecto públicamente. Ese mes, el diario platense El Día publicó un artículo de opinión del Arzobispo de La Plata, Héctor Aguer. Se titula "La fornicación" (23/08/2016) y se habla sobre la "cultura fornicaria", el matrimonio igualitario y los vicios (moralessexuales) de la sociedad argentina actual. Dos meses después, el mismo diario difundió otro texto de Aguer, "¿Es justo todo lo legal? La injusticia de un Decreto" (4/10/2016). Allí versa sobre la Ley de Identidad de Género, donde el autor se muestra contrario a la gratuidad de los tratamientos hormonales y quirúrgicos para las personas trans. Y en septiembre de 2017, Aguer prohibió la enseñanza sobre la "teoría de género" y el matrimonio igualitario en las escuelas católicas que dependen de la Arquidiócesis de La Plata a través del decreto 096/2017. Otros sucesos fueron la razzia policial que clausuró una fiesta drag en La Plata y en el mes de julio y la detención de una pareja de mujeres en la estación de Constitución en 2017. Estos acontecimientos se suman a otros que ocurrieron en otras latitudes, como los asesinatos en la disco gay mexicana en mayo de 2016 y con la masacre de Orlando en la disco Pulse en junio de 2016, que dio lugar al surgimiento del hashtag \#MatarGaysNoEsDelito solo unos días después del hashtag \#NoALaAdopcionGay; ambos fueron trending topic en Twitter en Argentina en junio de 2016. De forma paralela, y de forma cotidiana, los niños y adolescentes homosexuales y trans deciden suicidarse tras ser víctimas de hostigamientos homofóbicos en la escuela, tal como observa en un informe la Comisión Interamericana de Derechos Humanos (2015). En Argentina, el bullying homobilesbotransfóbico es más frecuente en las escuelas privadas y especialmente en las clases de Educación Física, como muestra un reporte de la organización 100\% Diversidad y Derechos (2016).
} 


\section{PROPUESTA METODOLÓGICA}

Aquí avanzamos con el desarrollo de nuestra estrategia metodológica cualitativa principalmente queer. Se explicitan las técnicas y los métodos que empleamos para el abordaje de 5.095 comentarios publicados en Tod@s y Boquitas pintadas y los editoriales de las versiones digitales de los diarios Clarín y La Nación entre 2012 y 2015. Más adelante, exponemos el protocolo de entrevistas semi-estructuradas para dialogar con los responsables de los blogs, Bruno Bimbi y Verónica Dema, acerca de las tareas de moderación que permiten la eliminación o publicación de comentarios discriminatorios y violentos en sus blogs. Seguimos con un esbozo de las preguntas que guiaron nuestras conversaciones con activistas LGBTIQ y otros referentes sobre temas de diversidades y disidencias sexo-genéricas, y finalmente reflexionamos acerca de las consideraciones metodológicas sobre el estudio de las violencias.

\subsection{Marco metodológico}

En línea con nuestro posicionamiento teórico-político, optamos por construir una estrategia metodológica que nos permite reflexionar analítica y críticamente sobre nuestro objeto de estudio desde un enfoque feminista y queer. Esto nos obliga a trabajar sobre las tensiones que articulan los estudios queer con las teorías feministas y con los estudios culturales y las investigaciones sobre Internet a fin de propiciar nuestro análisis sobre las representaciones discursivas que detentan los medios hegemónicos Clarín y La Nación sobre las personas LGBTIQ a partir de sus líneas editoriales por medio de los comentarios publicados en los blogs Boquitas pintadas y Tod@s entre 2012 y 2015 y de los editoriales que publican en sus diarios digitales en ese período. Nuestro análisis 
responde a nuestro propósito de realizar una reflexión teórica sobre las prácticas discriminatorias y violentas que afectan a las personas LGBTIQ en la actualidad.

Siguiendo a Sharlene Hesse-Biber et al (2015), avanzamos con una mirada principalmente cualitativa con un enfoque multimétodo y que triangulará distintos métodos de investigación para explorar los procesos sociales de construcción y negociación de sentidos. Al decir de Guillermo Orozco Gómez:

La perspectiva cualitativa es un proceso de indagación de un objeto al cual el investigador accede a través de interpretaciones sucesivas con la ayuda de instrumentos y técnicas, que le permiten involucrarse con el objeto para interpretarlo de la forma más integral posible (1996: 83)

Estas técnicas y métodos cualitativos serán los instrumentos con los cuales intentaremos responder nuestras preguntas de investigación con interés por recuperar los sentidos nativos de los sujetos implicados en estos procesos con el fin de complejizar nuestra comprensión sobre los procesos a tratar. Asimismo, creemos importante aclarar que dicha estrategia puede verse modificada en la medida de que nuestro objeto lo exija. Este andar a tientas se vincula con el hecho de los métodos o técnicas que empleamos son más bien un desprendimiento de las teorías y de los objetivos que acompañan nuestro proceso de investigación. Además, en el transcurso del desarrollo de esta investigación, iniciada en 2012, han acaecido distintos procesos sociopolíticos que nos han obligado a revisar no solo nuestros objetivos, nuestras preguntas y nuestro corpus sino también a ampliar el alcance de nuestro estudio a raíz de los crecientes debates en el país acerca de la regulación de los contenidos de Internet y sobre proyectos impulsados por las organizaciones LGBTIQ. Ante esta situación, tuvimos que apropiarnos de otras herramientas metodológicas que nos permitieran responder los nuevos interrogantes.

En consecuencia, tomamos distintas herramientas e instrumentos para el abordaje de los elementos que componen nuestro universo de análisis. En primer lugar, nos aproximamos a la etnografía virtual a fin de abordar las intervenciones en cada blog, las interacciones y los modos de participación. Luego, trabajamos con análisis crítico del discurso con el propósito de analizar las representaciones discursivas discriminatorias sobre las personas LGBTIQ en los comentarios de los blogs, sus prácticas de resistencia y los editoriales de los dos diarios argentinos. A su vez, realizamos una serie de entrevistas semi-estructuradas para comprender los procesos tal 
como otros la experimentan. Por eso decidimos contactar a los responsables y moderadores de los blogs: Verónica Dema y Bruno Bimbi. También dialogamos con activistas y referentes teóricos y políticos sobre discriminación y violencia en Internet o sobre cuestiones de diversidad sexo-genérica. De este modo, entablamos comunicación con Dora Barrancos, miembro del Directorio de CONICET; con Paula Carri, directora del Programa Plataforma por una Internet Libre de Discriminación del INADI; con María Rachid, ex vicepresidenta del INADI y una de las fundadoras de la FALGBT, La Fulana y la Mesa Nacional por la Igualdad; y con ocho activistas pertenecientes a organizaciones de disidencia sexo-genérica y de derechos humanos, incluyendo las organizaciones SIGLA, FALGBT, 100\% Diversidad y Derechos, La Fulana y OTRANS La Plata. ${ }^{26}$

Como se puede observar, la presente investigación traspasa los bordes porosos y movedizos del campo comunicacional y toma como objetos los procesos que construye en tanto objetos, que del mismo modo pueden abordarse desde múltiples disciplinas. Para ser coherente con esto también transgredimos los confines de lo comunicacional para la elaboración de nuestra estrategia metodológica ya que tomaremos prestadas técnicas y métodos de otras disciplinas, como el método etnográfico y el análisis crítico del discurso, en tanto lo que nos preocupa observar es la dimensión significante del recorte de "realidad social" que delimitamos (Sautú, 2003). Esto demanda que utilicemos métodos y técnicas que respeten la perspectiva de los actores implicados en los procesos comunicacionales y que además nos permita tener una mirada holística acerca del objeto a estudiar. Por esto buscaremos dialogar con ellos a fin de triangular sus representaciones con nuestro análisis de los textos. Estos métodos y técnicas se complementan entre sí y se sitúan en diálogo con la perspectiva queer y con los estudios de Internet. Desde ya que esto nos presenta nuevos desafíos a la hora de planificar y realizar la investigación y de documentar e interpretar los datos. Desde los estudios de Internet se han remediado distintos métodos cuantitativos y cualitativos de investigación que fueron utilizados anteriormente para indagar sobre otras tecnologías y sobre otros procesos comunicacionales y no comunicacionales. Ejemplo de ello son las etnografías,

\footnotetext{
26 Nótese que las entrevistas originalmente fueron realizadas en 2015 como parte de una investigación paralela, titulada "Discriminación en la web: testimonios de activistas LGBTIQ" y enviada para publicar en el libro "Género y TIC" de El Colegio de la Frontera del Sur (México), texto que actualmente se encuentra en proceso de revisión. Luego se decidió incorporarlas en la tesis por el aporte que representaban para las discusiones que aquí desarrollamos.
} 
las encuestas, la observación participante, el análisis de contenido y el análisis crítico del discurso (Jensen, 2011).

Más aún, decidimos queerizar esos métodos en la medida de que nuestro diseño metodológico cualitativo es ante todo queer. Debemos aclarar que en sí no existe una metodología queer propiamente dicha, así como tampoco existe una teoría monolítica queer ni una definición unívoca de este concepto, como ya vimos. Tal como apuntan Kath Browne y Catherine J. Nash (2016), existen diversas aproximaciones queer en las ciencias sociales que cuestionan los paradigmas de investigación que han contribuido a sostener los pilares del conocimiento científico que justifican la desigualación de determinados sectores sociales. Al igual que otros paradigmas críticos, rompen con las ideas de que el investigador es un ser objetivo, de que existe una realidad para ser descubierta y de que los sujetos-objeto de investigación son meros datos. Si bien cabría señalar que este aporte no es propio de las teorías queer, sí lo es lo siguiente: el sujeto que investiga debe evidenciar su posicionamiento identitario (o desidentitario) sexual y genérico y su lugar en otras tramas de relaciones de poder en la medida de que su ejercicio es intrínsecamente político, crítico y transformador de sí mismo, de los procesos que analiza, de las condiciones de las que forma parte y de los sujetos-objeto con los que se relaciona. Su objetivo último entonces consistirá en desestabilizar los órdenes sociales hegemónicos y normativos que jerarquizan y privilegian algunas identidades, subjetividades, prácticas, afectividades y corporalidades por encima y a cuestas de otras. Entonces no será posible separar la identidad ni las experiencias de vida del investigador de las propias de los sujetos investigados, así como tampoco podrá pasarse por alto la reflexión acerca de cómo participa la subjetividad y la postura ética de quien investiga sobre las decisiones que toma a la hora de construir su objeto, de definir sus preguntas de investigación, de elegir qué métodos y técnicas emplear, de seleccionar las categorías analíticas, de documentar los procesos observados, de (re)presentar y de recuperar la voz de los protagonistas y de comunicar los resultados y las conclusiones de su investigación. Como concluyen las autoras, las metodologías queer por lo tanto son distintas maneras de incorporar la perspectiva queer a lo largo de todo el proceso de investigación, mientras que al mismo tiempo se resisten de manera permanente a convertirse en ortodoxia o norma con el fin de conservar su potencial de abyección y subversión.

Sin pretensiones de clausurar el debate sobre qué se entiende por metodologías queer ni de elaborar una definición que las limite conceptualmente, nos parece propicio 
recuperar y seguir los aportes de Joshua M. Ferguson (2013), quien también apuesta por un marco teórico-metodológico feminista y queer en rechazo a las investigaciones positivistas y empiricistas con pretensiones de verdad. Incluso sugiere queerizar y hacer implosionar a los fundamentos científicos sobre los que se funda la investigación cualitativa para deconstruirlos y reconstruirlos en oposición a los discursos científicos que homogenizan las observaciones y las experiencias individuales de los sujetosobjeto. Dice que "los métodos cualitativos queer requieren una sensibilidad constante para evitar reforzar la marginalización dentro de un estudio en nombre de una ciencia racional, completa y ordenada" (Ferguson, 2013: 8). ${ }^{27}$ Agrega que la investigación cualitativa feminista y queer debe enfatizar por igual la alteridad y la pluralidad de voces en sus propios términos. Al abordar esta "colección de narrativas" no se deben universalizar las historias ni las experiencias individuales. Por lo tanto, se debe optar por métodos como grupos focales, encuestas y entrevistas para reconocer, valorizar y escuchar a la diversidad de sujetos queer en todas las instancias del proceso de investigación de forma responsable y con un compromiso activo por entender y por hablar desde la diferencia, sin estabilizar identidades y sin silenciar las voces queer. También debe hacerse un ejercicio ético auto-reflexivo para pensar cómo las vivencias personales del investigador queer y su tránsito por la marginalidad pueden incidir sobre la forma en la que observa y enmarca a los individuos queer en su propia tarea. Finalmente, nos recuerda al igual que los exponentes de los estudios culturales latinoamericanos que la investigación cualitativa es un modo de intervención situado en el que el sujeto que investiga opera como un agente de cambio.

Es cierto que las agendas de los estudios feministas y queer no fueron siempre por el mismo camino, pero tal como señala Judith Butler (1994), no tiene sentido separar las áreas de indagación de unos y de otros para reservar a las teorías queer el dominio de la sexualidad y a los feminismos el género y/o el sexo. Más aún, los entrecruzamientos teóricos y las discusiones entre estos pueden complejizar la mirada sobre los procesos a analizar. La autora reconoce que la búsqueda por apropiarse de alguno de estos objetos de estudio y métodos pudo haber obedecido a un intento por dotar de autonomía y de legitimidad científica al feminismo, a los estudios gay-lésbicos y más adelante a los estudios queer. Asimismo, reconoce que los últimos pueden ser

27 Traducción propia del siguiente fragmento: "Queer qualitative methods require a constant sensitivity to avoid reinforcing marginalization within a study for the scientific sake of being rational, complete and tidy". 
más inclusivos al abordar asuntos vinculados con las minorías sexuales y las configuraciones normativas de lo humano. Sin embargo, pueden correr el riesgo de volverse conservadores al tratar de delimitar un terreno específico de indagación y al correr el riesgo de priorizar determinados temas, de reforzar una hetero u homonorma y de sostener la supremacía masculina. Por ello invita a resistir a la domesticación de lo queer, algo que David Halperin (2003) teme que sucederá a menos que se renueve su potencial radical para la crítica y para pensar lo impensado.

En consecuencia, hoy tanto los estudios feministas como los queer se enfrentan con distintos desafíos. Virginia Olesen (2011) observa que las investigaciones cualitativas feministas tienen un alcance que es tan amplio y diversificado que deben atender diferentes particularidades. Los estudios feministas abarcan trabajos orientados al cambio social, que incluyen a los estudios poscoloniales y los postestructurales, mientras que otros son hechos por y para un grupo específico de mujeres. Además hay tendencias críticas, como por ejemplo las investigaciones con miradas interseccionales o con posiciones decoloniales, así como escritos que abordan las problemáticas transversales a todas teorías feministas en general, las influencias que recibe y sus proyecciones futuras. Los problemas que hoy en día que afectan a esta corriente de pensamiento en su totalidad oscilan entre la falta de problematización del lugar sobre participantes e investigadores, sobre el lugar de la experiencia y sobre los conceptos clave de las teorías, incluyendo al de "género". Sus desafíos a futuro entonces serán no solo avanzar hacia la resolución de esos temas sino que también se debe profundizar la reflexión sobre cómo evitar replicar los mecanismos de opresión y privilegio que oprimen a sectores marginalizados, y sobre cómo generar acciones y políticas orientadas a alcanzar un grado mayor de justicia social.

Por otro lado, para Ken Plummer (2011) los estudios queer atraviesan problemas similares pero a ello se le suma el hecho de que se encuentran en medio un dilema queer, entre el impulso a deconstruir la categoría queer y el impulso a mantenerla como estrategia política, algo como aquello que Joshua Gamson (2002) afirmaba con respecto a los activismos queer. Otro de sus problemas es su falta de trascendencia temporal y espacial; si bien no debe aspirarse a universalizar conclusiones, es importante que las teorías queer abran diálogos tolerantes y empáticos con otras disciplinas, con otras generaciones y con otras culturas. A estos asuntos teóricos se les agrega uno práctico referido a la indeterminación sobre los métodos. Como se sugirió con anterioridad, es deseable no resolver esta ecuación para emplearla como aliciente que permita trastocar 
los cánones de lo establecido y de aquella ciencia que se dice neutra para legitimar los sustentos ideológicos que oculta mientras que califica como "verdad" los argumentos que perpetúan la desigualdad social. Huir de la normalización conlleva ciertos riesgos, si bien el autor propone múltiples alternativas para elaborar estrategias metodológicas que respondan a un marco teórico-epistemológico queer. En primer lugar se refiere a métodos tales como la relectura queer de textos culturales, que es el más utilizado; allí se pone énfasis sobre aquellas producciones que analizan cómo se da forma a la sexualidad. Otros ejemplos son las etnografías subversivas, una forma de observación participante crítica; las metodologías hurgadoras, que entrecruzan distintas técnicas de diferentes áreas del saber; y el terrorismo del género y la performatividad etnográfica, en las que se buscan transgredir las barreras de los géneros. Él, por su parte, apuesta por adoptar un cosmopolitismo metodológico: métodos más bajados a tierra, que miren realidades locales sin pasar por alto las complejidades de la vida social a nivel global. En suma, los métodos queer no son nuevos sino que toman prestados los métodos cualitativos de las ciencias sociales y los adaptan, con la particularidad de que lo hacen para poner bajo amenaza los órdenes genérico-sexuales vigentes.

Como se ve, a lo largo de esta investigación sostenemos un posicionamiento ideológico-político marcado. Por eso, y para atender a los criterios de rigor, validez y credibilidad científica, adherimos a la propuesta de Patti Lather (1986) y James R. Sheldon (2010) con respecto a los aspectos que debe perseguir una investigación feminista y queer que desafía el status quo. Podríamos sintetizar sus aportes señalando cuatro elementos clave: 1) la triangulación entre distintas perspectivas teóricas, métodos y fuentes de información; 2) la confrontación entre teorías y las experiencias cotidianas de las personas en un proceso sistemático de reflexividad; 3) la socialización de las conclusiones preliminares con los participantes de la investigación para conocer sus concepciones; y 4) la catalización, o el grado de transformación y empoderamiento de los protagonistas a partir de su participación en el proceso de investigación. A estos criterios, Sheldon agrega un quinto: tener un compromiso centrado en los valores de las teorías de fondo. No solo es coherente atender a estos cinco principios a fin de evitar que se nos acuse de ser especulativos, de ser tendenciosos o de estar imponiendo sentidos, sin respetar las voces de aquellas personas a las que nos referimos. Si bien no contactamos a los comentaristas de los blogs ni a los autores de los editoriales, sí dialogamos con los responsables de los blogs, con activistas LGBTIQ y con otros referentes con el propósito de triangular sus ideas con las que extrajéramos de nuestro 
análisis discursivo. De este modo tratamos de re-presentar y canalizar las voces de sujetos alternizados y silenciados que son afectados en mayor o menor medida por las problemáticas que aquí nos competen y que desearíamos ayudar a transformar. Volveremos sobre esto más adelante.

\subsubsection{Los comentarios}

Para el estudio de los comentarios, utilizamos técnicas de capturas de pantalla como forma de registro y de recolección de datos con el fin de disponer de copias fieles de los comentarios publicados en los blogs entre 2012 y 2015. Dicha recolección se realizó en enero de 2016. Asimismo, utilizamos un script para enumerar los datos y construir el corpus de 5.095 comentarios. ${ }^{28}$ Esto nos permite operar siguiendo los aportes de Christine Hine (2000) y los métodos que propone para hacer una etnografía virtual en la medida de que actuaremos como observadores no participantes, si se quiere "invisibles", para construir nuestro corpus, describir los blogs y acercarnos a los editoriales de Clarín y La Nación. Por otra parte, creemos necesario acercarnos a las herramientas teórico-metodológicas que ofrece el análisis crítico del discurso (ACD). Siguiendo a Ruth Wodak:

El ACD permite analizar las presiones provenientes de arriba y las posibilidades de resistencia a las desiguales relaciones de poder que aparecen en forma de convenciones sociales. Según este punto de vista, las estructuras dominantes estabilizan las convenciones y las convierten en algo natural, es decir, los efectos del poder y de la ideología en la producción de sentido quedan oscurecidos y adquieren formas estables y naturales: se los considera como algo "dado". La resistencia es así considerada como una ruptura de las convenciones y de las prácticas discursivas estables, como un acto de "creatividad" (2003a: 3)

El ACD estudia al lenguaje, entendido como práctica y construcción social, donde es relevante el contexto en el que se usa una lengua. Se interesa por la relación entre la palabra y el poder, dado que los académicos de la lingüística crítica y los

\footnotetext{
${ }^{28}$ Agradecemos al Ing. Leonel E. Bracco (IIB-INTECH / UNSAM) por su contribución, quien nos ayudó a cuantificar, rotular y enumerar los comentarios escritos y publicados por usuarios en los artículos en cuestión; a eliminar los mensajes de spam y a aquellos publicados por la plataforma, como por ejemplo aquellos que decían que un comentario fue eliminado por el moderador, sin mostrar su contenido original. Su script nos permitió recuperar los apodos, destinatarios y el contenido de cada posteo.
} 
analistas críticos del discurso sostienen que las relaciones de dominación, discriminación, poder y control se manifiestan, sostienen o subvierten a través del lenguaje. En los discursos se plasman representaciones sociales que condensan ideas, valores y creencias (esto es, ideologías) y se organizan las actitudes de los grupos sociales, que remiten a opiniones generalizadas con respecto a temáticas socialmente relevantes (Van Dijk, 1996) y es por ello que nos interesamos por el análisis de cómo dos medios hegemónicos representan discursivamente a las personas LGBTIQ tanto en los comentarios publicados en los blogs entre 2012 y 2015 como también en los editoriales de Clarín y La Nación en dicho período a través de sus políticas editoriales y de las actividades de moderación de los blogs.

En este sentido, Wodak (2003b) agrega que las personas emplean distintas estrategias en el plano del discurso para marcar su posicionamiento valorativo sobre otros seres, eventos, fenómenos u objetos. A través de esas prácticas se establecen relaciones sociales de identidad y de diferencia, mostrándose de modo positivo al propio grupo de pertenencia y de forma negativa al "otro". Estas estrategias son la referencia o nominación, la predicación, la argumentación, la perspectiva y la intensificación o mitigación; todas buscan alcanzar objetivos políticos, sociales, psicológicos y lingüísticos. Analizaremos entonces las categorizaciones que se emplean para la construcción discursiva de un "nosotros" y un "ellos" (referencia); las atribuciones o etiquetamientos apreciativos o peyorativos sobre personas o procesos (predicación); los topoi o lugares comunes que justifican y respaldan esas cualidades atribuidas (argumentación); el involucramiento del punto de vista del emisor (perspectiva); y la fuerza ilocucionaria discursiva (intensificación o mitigación).

Por nuestro interés por comprender los modos de representación discursiva que recaen sobre las personas LGBTIQ en el territorio material y simbólico que es Internet, complementaremos el estudio de las estrategias discursivas con la teoría del appraisal o de la valoración desde Nora Kaplan (2004), Peter White (2004) y James R. Martin (2004). De este modo, analizaremos los posicionamientos actitudinales y valorativos de las personas sobre lo que dicen, sobre sus interlocutores reales y potenciales y sobre los procesos sobre los que versan; y analizaremos los mecanismos con los que negocian sus evaluaciones en estas relaciones interpersonales, con las cuales se mostrarán distantes de quienes no son afines a su postura y se marcarán discursivamente más próximos a quienes sostengan una mirada más cercana a la propia. 
Investigaciones anteriores se han encargado del estudio de las interacciones en los blogs desde distintos marcos teóricos y metodológicos. Así, podemos referirnos a las obras de Alicia Carrizo (2015), quien analiza los comentarios de los foros de diarios digitales argentinos. Desde una perspectiva multimodal y multidimensional, observa que en aquellos espacios hay expectativas de desacuerdo y que acontecen expresiones valorativas violentas en el marco de distintas secuencias argumentativas. En esos textos, los interlocutores expresan su opinión sobre los protagonistas de las noticias sobre las que se desarrolla el intercambio y que funcionan como disparadores; o bien pueden opinar sobre el redactor o, principalmente, sobre otros comentadores. Esta investigación toma a los comentarios como parte un tipo de género dialógico conversacional, en líneas similares a lo que esboza Valentina Noblia (2009) en relación con los chats.

Otros análisis se focalizan sobre la tipificación de las modalidades de participación en blogs (Pérez Riedel, 2014) o en foros educativos (Constantino, 2006), donde se enumeran y describen formas más o menos corteses de interactuar con otros comentaristas. De este modo, se percibe la existencia de participaciones anómalas y disruptivas, o de intercambios groseros. A su vez, se identifican usuarios con participaciones numerosas, mientras que hay usuarios que solo participan una vez. En este orden de cosas, autores como Greg Myers (2010) sugieren que de hecho los comentaristas que participan en debates online están más interesados por expresar su propia opinión y por marcar cuál es su postura personal sobre un tema y menos por deliberar sobre él. Ellos exaltan su posicionamiento y señalan su acuerdo o su desacuerdo con los otros comentaristas a través del uso de marcadores textuales como "yo pienso" (I think) o adverbios como "en realidad" (actually). Estos comentarios pueden canalizar formas de acción social progresiva así como pueden encarnar la figura del troll, aquel que adrede esparce rumores falsos, transmite ataques personales y desvía los temas de discusión. En suma, para el autor los blogs podrán ser independientes de los medios de comunicación hegemónicos, pero no lo son tanto de las ideologías reinantes y de las campañas institucionalmente organizadas.

Es interesante ver que varios de los estudios que nombramos se centran en el análisis lingüístico o semántico de los textos y en los usos cotidianos en Internet. Esta parece ser la tendencia que siguen las investigaciones sobre el espacio digital, un entorno cada vez más mediado por el lenguaje. Para Naomi Baron (2011), Internet tuvo un gran impacto sobre la cultura escrita, tal como sucedió anteriormente con otras tecnologías de la escritura como la imprenta. Así, se redefinen cuestiones vinculadas 
con la ortografía y puntuación y se acentúa el uso de abreviaturas y expresiones propias de la oralidad, que incluso permiten recuperar el carácter facial de los gestos con el uso de emoticones. También volvió más relativos e informales los intercambios escritos, que a su vez son más acotados e instantáneos. Al mismo tiempo, modificó los hábitos de lectura y las maneras en que nos comunicamos con otras personas: podemos escribirnos con seis personas en simultáneo y de inmediato dejar de hablarles. Estos cambios en el lenguaje y en las prácticas comunicacionales no son causales sino que vienen de la mano con transformaciones socioculturales, económicas y tecnológicas, tal como indican David Barton y Carmen Lee (2013): estos autores afirman que hoy en día la centralidad de la mediación escrita está en aumento gracias a Internet, aunque no se puede ignorar que en el uso del lenguaje en Internet se pueden emplear otros elementos no textuales con el fin de producir sentidos y de representarse a sí mismo dentro de las posibilidades y limitaciones de los entornos virtuales.

Si bien la comunicación en Internet es principalmente escrita, hay otras formas paratextuales e hipertextuales, visuales, sonoras y audiovisuales, que desde el análisis multimodal se denominan "modos". Ahora bien, debemos indicar por qué nos distanciamos de este enfoque teórico-metodológico. Para empezar, Carey Jewitt (2014) define al análisis multimodal como un conjunto de distintas perspectivas o aproximaciones interdisciplinarias que estudian cómo se comunican y se relacionan las personas y de qué maneras producen sentidos a través del uso del lenguaje oral o escrito, el tono de voz, la imagen, los gestos, la mirada, la postura corporal, entre otros. Cada uno de estos modos posee funciones y potencialidades de significación específicas, si bien es posible que a veces predomine un modo por sobre el resto. Desde este encuadre, todos los intercambios son multimodales: los significados se realizan, se distribuyen, se reciben y se interpretan a partir de la selección y articulación de estos modos de representar y de comunicar en el marco dentro de un contexto sociocultural particular. Así, las personas seleccionan qué recursos semióticos emplear de la gama de recursos disponibles; transforman los modos existentes o crean unos nuevos según las necesidades de sus comunidades, sociedades e instituciones y según los cambios y los desarrollos en los entornos sociales y tecnológicos en los que se emplean estos recursos.

Jewitt (2016) agrega que las tecnologías digitales abren nuevas posibilidades de comunicación, representación e interacción, así como también permiten innovar en cómo se recopilan los datos multimodales, cómo se los transcribe, cómo se los analiza y cómo se los difunde. En el caso de los blogs, Jewitt propone observar qué elementos 
entran en juego y cómo se relacionan entre sí; encuentra que operan modos textuales, visuales (imágenes, dibujos, símbolos), colores (efectos, saturación, iluminación, transparencia, entre otros), fuentes tipográficas (tamaño, tipo de letra, estilo subrayado, negrita, bastardilla) y de diseño de la plataforma o layout (formato, organización, encuadre, orientación). Así, desde un análisis multimodal, sería relevante ver por ejemplo si el autor o responsable del blog personalizó la plantilla y los colores de su sitio y si ello guarda coherencia con lo que transmiten los otros elementos.

Sin intenciones de desmerecer los aportes que el análisis multimodal puede realizar en los estudios de comunicación y de Internet no creemos necesario incorporar a nuestro estudio los ítems del párrafo anterior ya que no son de nuestro interés por tres razones. Primero, aquí nos centramos en los editoriales de los diarios y en las producciones de los usuarios de los blogs, quienes principalmente utilizan la palabra escrita para comunicarse. Solo en el sitio de Bimbi pueden incorporar imágenes y videos embebidos de YouTube, y en ambos pueden insertar enlaces a sitios externos como Wikipedia. En segundo lugar, estos usos suelen ser escasos y además cumplen una función accesoria, que quizás refuerce o amplíe el material escrito; se verá según el caso. Y por último, los usuarios tienen la libertad de decidir con qué imagen de display o avatar presentarse a sí mismos o bien pueden usar ninguna; si bien las fotos de perfil pueden funcionar como una forma de identificación de modo similar a la cara de una persona en la interacción no mediada, creemos a priori que este elemento no nos brindará información útil sobre los modos de representación discursiva acerca de las personas LGBTIQ. Por estos motivos, reiteramos nuestra decisión de trabajar sobre los textos escritos con las herramientas teóricas-metodológicas del ACD desde una perspectiva sociolingüística para comprender las representaciones en torno a las orientaciones sexoafectivas e identidades y expresiones de género no normativas. Así trabajamos sobre los comentarios publicados entre 2012 y 2015 en el blog Tod@s y Boquitas pintadas y sobre los editoriales de las versiones digitales de Clarín y La Nación. $^{29}$

\footnotetext{
${ }^{29}$ Como ya dijimos, nos interesamos por estos espacios por el posicionamiento ideológico de ambos medios en rechazo al reconocimiento de los reclamos y demandas de las personas LGBTIQ y por haber habilitado de manera paralela a que un activista reconocido en la comunidad LGBTIQ como Bruno Bimbi tuviera un blog con el Grupo Clarín; y en el caso de Boquitas pintadas, como modo de profundizar sobre nuestra investigación anterior. Las conclusiones de este escrito se limitan al estudio de dos sitios y dos medios en particular y no pretenden ser representativas ni extensivas con respecto a otras páginas web o a otros diarios digitales.
} 
En primer lugar nos ocupamos del análisis de 5.095 comentarios de los blogs publicados en un total de diez artículos difundidos en los dos blogs en el mismo período. Vimos que allí hubo un total de 406 artículos, que arrojaron una cifra total de 24.104 comentarios: en estos años, el blog de Bimbi tuvo 8.351 intervenciones, mientras que el de Dema recibió 15.753. Acotamos la búsqueda para trabajar solamente con aquellos posteos que tuviesen más de 300 comentarios. Este criterio de selección estuvo motivado por la suposición de que las publicaciones más comentadas son las que más convocan a los lectores, sea por su interés en los temas que abordan o por tratarse sobre asuntos que podrían considerarse controversiales, según el contexto, como ocurrió con un post de Bimbi sobre el proyecto de otorgar un subsidio a las personas trans mayores de 40 años que residían en la Ciudad Autónoma de Buenos Aires. Notamos que gran parte de los artículos no superaban los cien comentarios, por lo que creímos que el piso de 300 nos permitiría aproximarnos a responder los interrogantes que guían esta investigación. De este modo, redujimos nuestra selección a un total de diez artículos, con 5.095 comentarios en total. Realizamos el relevamiento de los mismos entre los días 19 y 20 de enero de 2016. Empleamos técnicas fotográficas de captura de pantalla para tener copias fieles de las intervenciones, que fueron enumeradas y catalogadas en un programa de edición de textos; allí, y de ahora en más, usamos la abreviación "Tx" para hacer alusión al blog Tod@s y "BP” para Boquitas pintadas. ${ }^{30}$

En los cuadros que siguen volcamos los datos recopilados con más detalle. En el primero mostramos la cantidad de artículos y comentarios publicados en cada blog entre 2012 y 2015, en los que se observa que la participación en BP duplica la de Tx (ver Figura A). En el siguiente, vemos que el año 2012 fue el que tuvo mayor cantidad de publicaciones tanto de los periodistas a cargo de cada espacio como de los usuarios. Vemos que la actividad de los responsables decrece con el pasar del tiempo pero no sucede lo mismo con la actividad de los comentaristas. Además, vemos que a mayor cantidad de artículos, es menor la cantidad de comentarios publicados en cada uno en promedio (ver Figura B).

Figura $A$

Cantidad de artículos y comentarios publicados

en Tod@s y Boquitas pintadas (2012-2015)

\begin{tabular}{|l|l|l|} 
Blogs & Artículos & Comentarios \\
\hline
\end{tabular}

${ }^{30}$ Ver Anexo. 


\begin{tabular}{|c|c|c|}
$\mathbf{B P}$ & 269 & 15.753 \\
\hline $\mathbf{T x}$ & 137 & 8.351 \\
\hline Cifras totales & $\mathbf{4 0 6}$ & $\mathbf{2 4 . 1 0 4}$ \\
\hline
\end{tabular}

Fuente: elaboración propia a partir de datos de los blogs

Figura B

Desglose de artículos y comentarios por blog, por año

\begin{tabular}{|c|c|c|c|c|}
\hline \multirow{2}{*}{ Cifras totales } & \multicolumn{2}{|c|}{ BP } & \multicolumn{2}{c|}{ Tx } \\
\cline { 2 - 5 } & Artículos & Comentarios & Artículos & Comentarios \\
\hline 2012 & 71 & 4.141 & 99 & 6.524 \\
\hline 2013 & 29 & 2.669 & 78 & 3.700 \\
\hline 2014 & 18 & 1.136 & 64 & 4.840 \\
\hline 2015 & 19 & 401 & 28 & 685 \\
\hline Total & $\mathbf{1 3 7}$ & $\mathbf{8 . 3 4 7}$ & $\mathbf{2 6 9}$ & $\mathbf{1 5 . 7 4 9}$ \\
\hline
\end{tabular}

Fuente: elaboración propia a partir de datos de los blogs

En el tercer recuadro solamente se exponen la cantidad de textos que tuvieron los artículos más comentados, ordenados de mayor a menor, y la cifra total de los escritos a analizar (ver Figura C). Al respecto, debemos señalar que nos interesamos por indagar sobre las participaciones que son discriminatorias y violentas con respecto a las personas LGBTIQ y las contestaciones que le merecen, pero todos los comentarios que relevamos no tienen estas características: las intervenciones varían y no todas aportan a nuestras preguntas de investigación. Sin embargo, decidimos no reducir la selección y conservar el número original para preservar el carácter conversacional de los escritos y dar cuenta de la interdiscursividad que caracteriza a las participaciones en los espacios online.

Figura $C$

Cantidad de comentarios en los artículos seleccionados

\begin{tabular}{|c|c|c|c|}
\hline Arts. & Comentarios & BP & $\mathbf{T x}$ \\
\hline 1 & Más comentado & 507 & 1.104 \\
\hline 2 & Más de 300 & 490 & 842 \\
\hline 3 & Más de 300 & 423 & 415 \\
\hline 4 & Más de 300 & 309 & 394 \\
\hline 5 & Más de 300 & 304 & 307 \\
\hline \multicolumn{2}{|r|}{ Total por blog } & 2.033 & 3.062 \\
\hline \multicolumn{2}{|c|}{ Total a analizar } & \multicolumn{2}{|c|}{5.095} \\
\hline
\end{tabular}

Fuente: elaboración propia, conteo propio 
Hechas estas aclaraciones, pasamos a mostrar los títulos, tópicos, fechas y cantidad de comentarios de los diez artículos que seleccionamos (Figura D):

\section{Figura D}

Artículos seleccionados, por blog, con temas, fechas y cantidad de comentarios

\begin{tabular}{|c|c|c|c|c|}
\hline & Artículos & Temas & Fecha & Com. \\
\hline \multirow{10}{*}{ 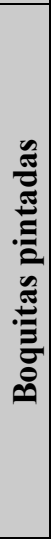 } & "Anita y sus dos mamás", un cuento infantil para pensar las familias diversas & \multirow[b]{2}{*}{ Literatura } & \multirow[b]{2}{*}{$19 / 11 / 13$} & \multirow[b]{2}{*}{423} \\
\hline & $\begin{array}{l}\text { http://blogs.lanacion.com.ar/boquitas-pintadas/arte-y-cultura/anita-y-sus-dos-mamas-un- } \\
\text { cuento-infantil-para-pensar-las-familias-diversas/ }\end{array}$ & & & \\
\hline & Hay ley de matrimonio igualitario, pero ¿por qué casarse? & \multirow[b]{2}{*}{ Película } & \multirow[b]{2}{*}{$05 / 12 / 13$} & \multirow[b]{2}{*}{309} \\
\hline & $\begin{array}{l}\text { http://blogs.lanacion.com.ar/boquitas-pintadas/arte-y-cultura/hay-ley-de-matrimonio- } \\
\text { igualitario-pero-por-que-casarse/ }\end{array}$ & & & \\
\hline & 30 años de democracia y 10 conquistas de la comunidad gay y trans & \multirow[b]{2}{*}{ Activismo } & \multirow[b]{2}{*}{$09 / 12 / 13$} & \multirow[b]{2}{*}{490} \\
\hline & $\begin{array}{l}\text { http://blogs.lanacion.com.ar/boquitas-pintadas/agenda/30-anos-de-democracia-y-10- } \\
\text { conquistas-de-la-comunidad-gay-y-trans/ }\end{array}$ & & & \\
\hline & ¿Todos y todas somos bisexuales? & \multirow[b]{2}{*}{ Bisexualidad } & \multirow[b]{2}{*}{$13 / 01 / 14$} & \multirow[b]{2}{*}{507} \\
\hline & $\begin{array}{l}\text { http://blogs.lanacion.com.ar/boquitas-pintadas/discriminacion-y-homofobia/todos-y- } \\
\text { todas-somos-bisexuales/ }\end{array}$ & & & \\
\hline & "Era mi mejor amiga y nos saludábamos con un beso en la boca" & \multirow[b]{2}{*}{ Bisexualidad } & \multirow[b]{2}{*}{$28 / 01 / 14$} & \multirow[b]{2}{*}{304} \\
\hline & $\begin{array}{l}\text { http://blogs.lanacion.com.ar/boquitas-pintadas/el-closet/era-mi-mejor-amiga-y-nos- } \\
\text { saludabamos-con-un-beso-en-la-boca/ }\end{array}$ & & & \\
\hline \multirow{10}{*}{$\begin{array}{l}\text { है) } \\
\stackrel{0}{0} \\
\qquad\end{array}$} & EI Papa pide perdón a los homosexuales & \multirow{2}{*}{ Religión } & \multirow{2}{*}{$01 / 01 / 12$} & \multirow{2}{*}{307} \\
\hline & http://blogs.tn.com.ar/todxs/2012/01/01/el_papa_pide_perdon/ & & & \\
\hline & EI diputado y activista gay brasileño Jean Wyllys le responde al papa Benedicto XVI & \multirow{2}{*}{$\begin{array}{l}\text { Religión y } \\
\text { política }\end{array}$} & \multirow[b]{2}{*}{$14 / 01 / 12$} & \multirow[b]{2}{*}{394} \\
\hline & $\begin{array}{l}\text { http://blogs.tn.com.ar/todxs/2012/01/14/el_diputado_y_activista_gay_brasileno_jean_wyl } \\
\text { lys_le_responde_al_papa_benedicto_xvi/ }\end{array}$ & & & \\
\hline & Daniel Zamudio & \multirow{2}{*}{ Homofobia } & \multirow{2}{*}{$25 / 03 / 12$} & \multirow{2}{*}{415} \\
\hline & http://blogs.tn.com.ar/todxs/2012/03/25/daniel_zamudio/ & & & \\
\hline & EI Papa que huyó por amor (y se fue a vivir con su secretario) & \multirow{2}{*}{ Religión } & \multirow{2}{*}{$15 / 02 / 13$} & \multirow{2}{*}{1.104} \\
\hline & http://blogs.tn.com.ar/todxs/2013/02/15/georg_e_joseph/ & & & \\
\hline & Hablemos del subsidio para travestis y transexuales & \multirow{2}{*}{$\begin{array}{l}\text { Subsidio } \\
\text { trans }\end{array}$} & \multirow{2}{*}{$27 / 11 / 14$} & \multirow{2}{*}{842} \\
\hline & http://blogs.tn.com.ar/todxs/2014/11/27/subsidio/ & & & \\
\hline
\end{tabular}

Fuente: elaboración propia

En una primera aproximación a los blogs, y con los datos plasmados en el último cuadro, vemos que los artículos más comentados y de mayor debate en Tx son sobre religión. Allí también se abordan temas de política internacional, especialmente sobre política argentina y brasilera, así como se habla de deportes, crímenes de odio, películas y series, entre otras cosas. En BP, los más comentados entre 2012 y 2015 fueron sobre literatura y sobre bisexualidad, si bien en ese espacio se publican posts sobre diversos tópicos, tales como estilo de vida, teatro, cine, para nombrar algunas. En principio, notamos una diferencia inicial respecto a los asuntos que tratan estos sitios: el blog de Dema habla más sobre testimonios de vida y sobre lo que podría catalogarse velozmente como "de interés general", mientras que el de Bimbi se vincula más con su perfil como 
activista LGBTIQ ya que principalmente discute problemáticas ligadas a las reivindicaciones del colectivo.

Por otra parte, en este primer acercamiento notamos que los comentarios publicados en cada blog tienen pequeñas diferencias. Si bien nos ocuparemos de la descripción de los espacios y de los comentarios más adelante, adelantamos que en la sección de comentarios de BP se pueden redactar textos que no pueden incluir imágenes pero sí hipervínculos externos. En Tx pueden publicarse textos y enlaces pero además se pueden colgar imágenes fijas o en movimiento (videos embebidos), si bien esta funcionalidad apenas se utiliza. Asimismo, vemos que hubo intervenciones borradas en algunos de los artículos relevados, pero ello no conduce a la eliminación de las respuestas por parte de otros usuarios. Podemos suponer que los comentarios borrados infringen algunas normas o condiciones de uso o que los moderadores de cada espacio los consideraron violentos. Al respecto debemos indicar que no tuvimos acceso a todos los comentarios eliminados pero Verónica Dema nos facilitó cuarenta y tres de esos textos, por lo que decidimos incluirlos en nuestro análisis en el cuarto capítulo. ${ }^{31}$ Creemos que su análisis brindará información relevante para tener una mejor comprensión sobre los procesos interaccionales del blog que tiene a cargo.

Con respecto a los comentarios publicados, los tipificamos con Atlas.ti a partir de las entrevistas que tuvimos con Dema y con Bimbi donde se habló de la existencia de "dos bandos" de comentaristas: los que son violentos y los que no lo son. Tomamos una muestra aleatoria de 589 comentarios sobre un total de 5.095 con un margen de error de un $5 \%$ y un nivel de confianza de $99 \%$. Los dividimos por blog y por tipo de participación (violenta o no violenta) sobre el exogrupo, uno conformado por las personas LGBTIQ y aliados (LGBTIyA), y otro por las personas cisheterosexuales que se distancian de las primeras.

Figura $F$

Tipificación de comentarios

\begin{tabular}{|l|c|c|c|}
\hline \multicolumn{1}{|c|}{ Comentarios } & BP & Tx & Total \\
\hline No violento sobre cisheterosex & 72 & 138 & 210 \\
\hline Violento sobre cisheterosex & 63 & 38 & 101 \\
\hline No violento sobre LGBTIQyA & 28 & 101 & 129 \\
\hline Violento sobre LGBTIQyA & 72 & 77 & 149 \\
\hline
\end{tabular}

\footnotetext{
${ }^{31}$ Nos los envió a través de correos electrónicos en febrero y marzo de 2015 y autorizó su uso y difusión para la presente investigación.
} 


\begin{tabular}{|l|l|l|l|} 
Total & 235 & 354 & 589 \\
\hline
\end{tabular}

Fuente: elaboración propia, conteo propio

\section{Figura $G$ \\ Tipificación de comentarios en porcentajes}

\begin{tabular}{|l|c|c|}
\hline \multicolumn{1}{|c|}{ Comentarios } & BP & Tx \\
\hline No violento sobre cisheterosex & 30,64 & 38,98 \\
\hline Violento sobre cisheterosex & 26,81 & 10,73 \\
\hline No violento sobre LGBTIQyA & 11,91 & 28,53 \\
\hline Violento sobre LGBTIQyA & 30,64 & 21,75 \\
\hline Total & $\mathbf{1 0 0 , 0 0}$ & $\mathbf{1 0 0 , 0 0}$ \\
\hline
\end{tabular}

Fuente: elaboración propia, conteo propio

Allí encontramos que en BP más de la mitad de los comentarios son violentos, principalmente contra las personas LGBTIQyA y en segundo lugar, contra quienes no lo son. En Tx se violenta más a las LGBTIQyA que a quienes no lo son, pero allí predominan los intercambios no violentos. Veremos luego qué representaciones circulan en estos textos, qué relación tienen con las líneas editoriales de los diarios y con el rol de los moderadores.

\subsubsection{Los editoriales}

Para continuar con nuestro estudio del posicionamiento del medio en relación con los comentarios de los blogs, seleccionamos seis editoriales que se publicaron en los diarios digitales Clarín y La Nación entre 2012 y 2015. Empleamos los motores de búsqueda de cada sitio con los términos "matrimonio igualitario", "matrimonio homosexual", "matrimonio gay", "mismo sexo", "homosexual" "cupo laboral trans", “identidad de género", "subsidio trans" y "travesti”. Así encontramos numerosos artículos: algunos incluían una o dos de esas palabras pero no se referían específicamente a estos temas; otros hacían alusión a cuestiones políticas; por ejemplo, en La Nación se nombraba al matrimonio igualitario para hablar en contra de la gestión de Cristina Fernández o para referirse al Papa Francisco, el Vaticano y la Iglesia Católica. Por último, filtramos la búsqueda mediante la selección de la etiqueta "Opinión" o "Del editor al lector" con el propósito de analizar al menos un editorial por año, por medio y por temática. Recordamos que nos interesa ver de qué manera cada 
medio editorializa a favor o en contra de los temas relacionados con las personas LGBTIQ.

En el cuadro que sigue (Figura $\mathrm{H}$ ) transcribimos información de los editoriales con los que trabajaremos. Los analizamos con las mismas herramientas que empleamos para el estudio de los comentarios; a saber, etnografías digitales, registros fotográficos, teoría de la valoración y análisis de estrategias y representaciones discursivas.

\section{Figura $\mathrm{H}$}

Editoriales seleccionados, por diario, con temas, fechas y autor

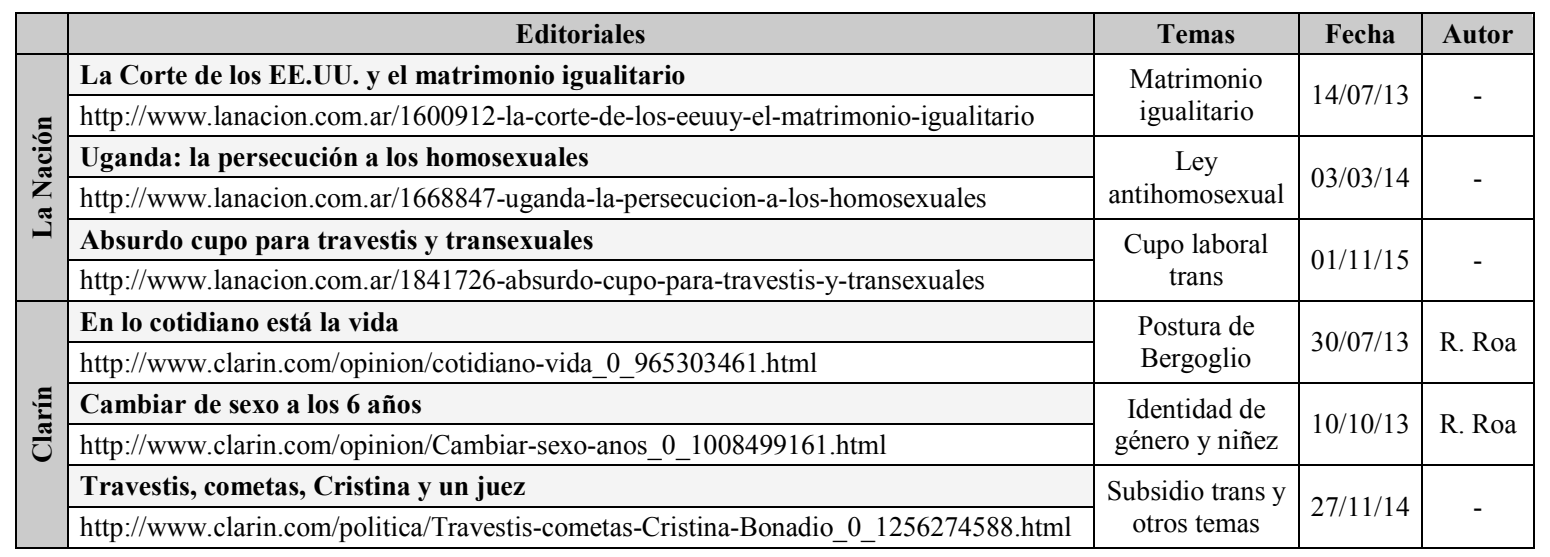

Fuente: elaboración propia

Como se observa, en primer lugar señalamos el diario y el título de cada editorial, ordenados por medio y por orden cronológico. Luego redactamos sintéticamente de qué trata cada escrito y cuándo se lo publicó. Finalmente indicamos quién firma el texto en el caso de que aparezca un nombre, como sucede en los casos del editor general y editor general adjunto de Clarín. En La Nación no aparece una firma, si bien tal vez no sea necesario que aparezca dado que los editoriales se caracterizan por representar la voz institucional del medio. Debajo de los títulos, el enlace por el cual se puede acceder a ellos.

Asimismo, vemos que hay editoriales no se refieren estrictamente a las personas LGBTIQ sino que abordan temas que se pueden asociar con las orientaciones, identidades y expresiones disidentes. Por el momento, podemos hacer dos comentarios preliminares a partir de la lectura de los titulares y de los cuerpos de los textos de este recorte: primero, que La Nación se encuentra más interesado que Clarín por marcar su posicionamiento ideológico sobre temas de diversidad sexo-genérica; y segundo, que la falta de tratamiento editorial sobre esos temas también da cuenta del posicionamiento 
ideológico de cada medio. Sin embargo, hay que decir que estos tópicos sí fueron y son abordados por fuera de la sección editorial en artículos periodísticos vinculados con problemáticas sociales, asuntos políticos o incluso temas artísticos; o fueron tratados en otros editoriales de modo tangencial o por fuera del período que delimitamos. ${ }^{32}$

Como dijimos, abordaremos los editoriales con las herramientas teóricometodológicas que ofrece el ACD. Pero el estudio de la prensa escrita ha sido objeto de indagación desde diferentes perspectivas del análisis del discurso, la sociolingüística y el estudio de los medios. Como apunta Colleen Cotter (2003), estas investigaciones suelen centrarse en los efectos de los medios en la perpetuación de las desigualdades sociales, en el análisis de las ideologías y prejuicios, en el rol de las audiencias, en los procesos de producción y redacción de las noticias, en las implicancias del uso de las citas textuales y el estilo indirecto y en los géneros de los artículos periodísticos. En todos los casos sugiere tener en cuenta que el discurso de los medios está compuesto por el texto y por su proceso de producción; por lo tanto, no debe pasarse por alto el rol que cumplen las audiencias en los mecanismos discursivos de construcción de los discursos mediáticos. Por eso es indispensable contar con una mirada interdisciplinaria que contemple los aportes de otras áreas del saber, como los estudios culturales, las teorías críticas, la semiótica y la sociología, entre otras. Estos postulados nos permiten propiciar nuestra investigación al considerar los editoriales como parte de procesos de circulación de sentido más amplios, en los que también participan los responsables de los blogs y los comentaristas, así como los activistas por los derechos de las personas LGBTIQ.

\subsubsection{Las entrevistas}

A fin de responder nuestras preguntas de investigación, realizamos una serie de entrevistas semi-estructuradas a diferentes actores entre 2015 y 2016. En primer lugar,

\footnotetext{
${ }^{32}$ Por lo tanto, no incluimos aquellos editoriales publicados antes de 2012 y después de 2015, como por ejemplo "Matrimonio y heterosexualidad" (La Nación, sin autor, 05/11/2009), donde se argumenta a favor de la preservación del matrimonio como institución para heterosexuales. Otros editoriales que no abarcamos de La Nación son "Cada vez más lejos de la naturaleza" (sin autor, 05/06/2011), donde se habla sobre un caso de maternidad homoparental; "La masacre de Orlando y el fácil acceso a las armas" (sin autor, 23/06/2016), donde se omite mencionar que Pulse, el lugar del crimen, era una discoteca gay y la posible carga homofóbica detrás del suceso. Tampoco incluimos editoriales de Clarín a favor de la sanción del reconocimiento igualitario del matrimonio, como "Premiar la sinceridad" (Roa, 13/06/2007), "No todo vale con tal de ganar" (Roa, 10/07/2010) y "Tolerancia y diversidad" (Kirschbaum, 11/07/2010).
} 
entrevistamos de forma individual a los responsables de cada blog para conocer en qué consiste la tarea de los moderadores de cada sitio y cómo se regula la publicación y eliminación de comentarios en esos espacios, actividad que a nuestro parecer constituye una forma de hacer hablar a los medios de los que forman parte. También dialogamos con activistas por los derechos de las personas LGBTIQ y con referentes y académicos abocados a los estudios feministas y de diversidad sexual y a la lucha contra la discriminación. ${ }^{33}$

Tal como indica Ezequiel Ander-Egg, las entrevistas semi-estructuradas:

Están basadas en un guion que el entrevistador utilizará con flexibilidad, tanto en el orden en que han de ser formuladas las preguntas, como en el modo de hacerlo. En cuanto al orden, el entrevistador utilizará la secuencia que estime oportuna; y en cuanto al modo de formularlas, en cada caso puede adaptarlas utilizando un lenguaje familiar con cada entrevistado (1990: 14)

No obstante, reconocemos que las entrevistas son una relación social artificial y asimétrica que permite comprender la realidad tal como otros la experimentan (Rosa, 2009). Por ello, creemos necesario vigilar nuestras técnicas e instrumentos de recolección de datos y conocer los límites de los instrumentos que empleamos para ver si debemos refinarlos en su aplicación. Al mismo tiempo, es importante reflexionar acerca de las condiciones y limitaciones de nuestra estrategia metodológica, por lo que no descartamos la posibilidad de ajustarla si lo viéramos necesario y pertinente.

Como dijimos, creímos necesario entrevistar a los responsables de los blogs: Verónica Dema, en el caso de Boquitas pintadas, y Bruno Bimbi, por Tod@s. Estas entrevistas buscaron obtener información para analizar y reflexionar sobre las actividades de moderación de los entornos virtuales y sobre la regulación de los comentarios que se publican en sus páginas web. Las preguntas de las entrevistas semiestructuradas son las siguientes: 1) ¿Cómo surge el blog?,2) ¿A quién está dirigido?, 3) ¿Cómo son los usuarios más o menos frecuentes?, 4) ¿Por qué creés que te eligieron para estar a cargo del blog? ¿Cómo llegaste?, 5) ¿Qué opinión le merecen los comentarios de los usuarios?, 6) ¿En qué consiste la figura del moderador?, 7) ¿Quién está a cargo de moderar el contenido que se publica?,8) ¿Cuál es la finalidad del rol del moderador y de las condiciones y restricciones de uso del blog?, 9) ¿Qué características tienen los textos moderados?, y 10) ¿Qué opinión le merece la actividad del moderador

\footnotetext{
${ }^{33}$ Estos intercambios fueron grabados y posteriormente desgrabados de audio a texto.
} 
frente a los comentarios violentos o discriminatorios y a la posibilidad de vulnerar el derecho a la comunicación?

Realizamos la entrevista a Verónica Dema el 29 de enero de 2015 en el edificio del diario La Nación, ubicado en Av. Libertador 101 (Vicente López, provincia de Buenos Aires, Argentina), tal como habíamos organizado previamente vía Facebook. En el intercambio, sin embargo, no se desarrolló como habíamos acordado. La entrevistada propuso hacer preguntas primero respecto al libro de quien escribe, diálogo que duró veinticinco minutos. Antes de comenzar nuestra grabación, Dema exclama que no tenía mucho tiempo y preguntó cuán extensa sería nuestra entrevista. Accede ante la respuesta de que serían diez preguntas cortas, pero se muestra apurada a lo largo de toda la conversación; con todo, nuestra grabación dura quince minutos, contando las interrupciones de los llamados telefónicos que recibió en su celular.

El intercambio con Bruno Bimbi tampoco estuvo libre de percances; inicialmente no recibíamos respuestas a los correos electrónicos que le enviábamos y cuando lo hizo nos indicó que él rara vez veía sus correos y que prefería que nos contactáramos por celular. Pero luego surgió otro inconveniente: supimos que el entrevistado vivía en Brasil. Ante la dificultad por encontrarnos personalmente acordamos comunicarnos vía Skype el 23 de septiembre de 2015. La conversación tuvo una duración de más de media hora; seguimos el primer protocolo de entrevistas pero también lo interrogamos por su rol como activista gay. Se recordará que el periodista impulsó la Ley de Matrimonio Igualitario desde la FALGBT, redactó el libro Matrimonio igualitario (2010) y participó en uno de los proyectos de ley por la actualización de la Ley Antidiscriminatoria. Retomamos el intercambio con Bimbi y con Dema como parte de nuestro trabajo analítico-reflexivo en el cuarto capítulo.

Por otra parte, a modo de otorgar protagonismo y voz a quienes más afectan las problemáticas que abordamos, decidimos acercarnos a esos sujetos queer a los que aludimos anteriormente; se trata sin más de activistas LGBTIQ que pertenecen a las organizaciones SIGLA, FALGBT, 100\% Diversidad y Derechos, La Fulana y OTRANS La Plata. ${ }^{34}$ Complementamos estas voces con la de referentes políticos y académicos, entre los que encontramos a Dora Barrancos, integrante del Directorio de CONICET; a Paula Carri, responsable del Programa Plataforma por una Internet Libre de Discriminación del INADI; a María Rachid, ex vicepresidenta del INADI, ex presidenta

\footnotetext{
${ }^{34}$ Para mantener el anonimato, no utilizaremos sus nombres ni apellidos.
} 
de la FALGBT, fundadora de La Fulana y Secretaria general de la Mesa Nacional por la Igualdad y Contra la Discriminación. Estos intercambios individuales y grupales se realizaron en el lugar de trabajo o de participación militante de cada uno entre los meses de agosto de 2015 y abril de 2016 y en promedio se extendieron por quince minutos. Esbozamos una serie de preguntas que más bien funcionaron como guías o ejes sobre los que se basó cada conversación. Ellas fueron: 1) ¿Cómo describirías tu participación en la organización?, 2) ¿Cómo describirías su presencia en la web?, 3) ¿Alguna vez los han atacado por su activismo en la web?,4) ¿Cuál es su postura ante estos hechos?, 5) ¿Qué medidas toman?, 6) ¿Alguna vez te discriminaron por Internet por tu activismo?, 7) ¿Y por tu identidad de género o tu orientación sexual?, 8) ¿Percibís alguna solución ante esta problemática?, y 10) ¿Creés que Internet puede funcionar como un medio para una comunicación no homofóbica e igualitaria?

Reiteramos que este protocolo sufrió modificaciones según el interlocutor. Por lo tanto, las preguntas a Carri por ejemplo apuntaron más a indagar sobre el funcionamiento de la Plataforma y a conocer las características de las denuncias recibidas; y en el caso de Barrancos, se la consultó por su valoración sobre la situación actual de las personas LGBTIQ y las problemáticas asociadas a la discriminación Internet. Fue transversal a todas las entrevistas nuestra inquietud acerca de las experiencias percibidas como violentas en la web y sobre la posibilidad de hacer de Internet un medio para la comunicación igualitaria y no homofóbica. Las preguntas también se revisaron a medida que el desarrollo de la conversación lo ameritaba y a medida que el contexto sociohistórico se transformaba. Se recordará que en esos meses transcurría un proceso electoral que derivó en un ballotage y que dividió las aguas entre dos partidos políticos: Cambiemos y el Frente para la Victoria. Finalmente resultó ganadora la primera fuerza política, lo que condujo a la asunción presidencial de Mauricio Macri. A su vez, cobraba notoriedad mediática y política la discusión sobre el proyecto de actualización de la Ley Antidiscriminatoria, convirtiéndose en el lema de la XXIV Marcha del Orgullo LGBTIQ. En 2016 se reitera esta consigna en su XXV edición, con otra frase que exige poner freno a la violencia institucional y asesinatos a personas trans, tal como mostraba un banner en la página de Facebook oficial de la Marcha.

Finalmente, con estas entrevistas esperamos poder triangular la perspectiva de todos los actores implicados en estos procesos (moderadores, activistas que a su vez son usuarios de Internet, y referentes) con las interpretaciones que emanen de nuestro 
análisis de los 5.095 comentarios y de los seis editoriales. Asimismo, creemos que nos encontramos frente al desafío de avanzar sobre la producción de sentido acerca de la producción social de sentido. Esto es la necesidad de abarcar a la comunicación como un objeto constituido y como un objetivo a construir, para complejizar la mirada y adscribir a una metaperspectiva de múltiples paradigmas con un enfoque transversal (Bessone, 2010). Sabemos que una de las particularidades del campo de la comunicación es su interés por estudiar procesos inacabados y, por lo tanto, sobre una amplia gama de objetos a constituir, siendo uno de ellos el estudio de las implicaciones socioculturales a la luz de los recientes cambios históricos y políticos con el propósito de garantizar equidad y democracia valiéndonos de las tecnologías de la información y la comunicación (Pineda, 2001). Creemos que los sentidos en torno a los usos y apropiaciones de las tecnologías digitales nos pueden ayudar a tener una mejor comprensión respecto a las problemáticas que enfrentan las personas LGBTIQ en un contexto posterior a la sanción de dos leyes que son paradigmáticas para la mayoría del colectivo. También nos permitiría vislumbrar los modos en que se detentan sentidos discriminatorios y violentos en los espacios virtuales, incluso en aquellos orientados a dar visibilidad a las demandas de esos sujetos.

\subsection{Consideraciones para el abordaje de las violencias}

Como podrán apreciar los lectores de este texto, el asunto de la violencia es transversal y más bien clave para nuestra investigación; por ello nos parece pertinente detenernos para reflexionar sobre las implicancias de su abordaje. En principio, el estudio de las modalidades que adoptan las prácticas violentas en Internet nos obliga a evidenciar el potencial analítico del término a fin de comprender su carácter polisémico y multifacético, que nos conduce a indagar sobre qué es un acontecimiento violento o discriminatorio para otras personas y no solo para nosotros mismos. En este sentido, la pregunta central es qué es un hecho violento y para quién, ya que, como bien señala David Riches (1986), un acto perpetrado por extremistas puede ser visto como un acontecimiento violento para unos mientras que puede constituir un acto heroico para otros. El autor, sin embargo, solo contempla situaciones donde se ejerce una agresión física y no vislumbra otros aconteceres de la vida cotidiana que pueden ser considerados 
violentos por sus ejecutores, sus víctimas o sus testigos; es decir, una palabra puede ser violenta para unos pero no para otros, y en la dificultad de discernir entre estos tipos de interpretaciones, el investigador debe procurar recuperar y respetar todas las posturas existentes con cautela de no imponer sentidos. Dicho en otras palabras, hay procesos de mediación subjetiva y de interpretación situada que no son comunes entre todos los sujetos que participan en un acontecimiento que puede ser violento. Por lo tanto, un saqueo a un supermercado, un acto de venganza, un linchamiento o un acto de "justicia por mano propia" pueden ser aconteceres violentos para algunos y para otros no; pero además para algunos puede tratarse de actos legítimos o ilegítimos, justos o injustos (ver Vilas, 2005; Auyero, 2007; Moreira, 2010; Pérez y Rebón, 2011; González et al, 2011, entre otros).

En las Ciencias Sociales, hay varias conceptualizaciones sobre la violencia que la equiparan a la agresión directa y otras que la definen como el sometimiento de una o más personas y no por eso son menos fatales. Incluso hay autores que hablan de violencia estructural, simbólica, divina y objetiva, las cuales pueden operar en conjunto con otras o bien de forma autónoma (Žižek, 2009). Hilando más fino, unos se refieren a la violencia legítima y a la ilegítima, siendo la última aquella que va en contra del bien común (Benjamin, 2001). Otras definiciones, en cambio, circunscriben la violencia a determinados territorios y la rotulan según su espacio de injerencia, según el grupo de personas a las que afectan o a las circunstancias de contexto de la que emanan, como las violencias asociadas a los delitos urbanos (Katz, 1988; Savenije, 2009; Isla y Miguez, 2003) o al crimen organizado vinculado con el narcotráfico (Bagley, 2012; Carrión, 2015, 2016). Recientemente aparecieron distintas maneras de nombrar aconteceres rotulados como violentos y que son tal vez menos observables pero no por ello menos recurrentes, como la psicológica, la mediática, la económica y la violencia institucional (Fernández, 2009). Estas modalidades de la violencia no son nuevas, solo que ahora han ganado mayor visibilidad a raíz de las demandas y reivindicaciones de los sectores vulnerados por las mismas. Sin embargo, como dijimos, no siempre hay consenso acerca de qué es violento y qué no, por lo tanto resulta crucial analizar la disputa de sentidos acerca de esa problemática cada vez que se decidan abordar procesos de esta índole.

No obstante, sin importar de qué modalidades de violencias se trate, sabemos que ellas dan cuenta de la existencia de desigualdades sociales y que, al mismo tiempo, son tan destructoras como productoras de un orden. Más aún, la violencia tendiente a la 
conservación de este orden en vistas a defenderlo y protegerlo de las fuerzas que lo amenazan (Scheper-Hughes y Bourgois, 2004). Por otra parte, sabemos que no hay momento de la historia que no haya sido marcado por los conflictos. Por ello, siguiendo a Sergio Tonkonoff (2014), podemos afirmar que la violencia es parte de la cultura y muestra los límites de lo aceptable. En otras palabras, la violencia no es ajena a una sociedad ni es externa; es un acontecimiento que en sus máximas expresiones interrumpe con lo cotidiano pero es sin más parte de la vida diaria. Por eso es que nuestra mirada inevitablemente estará inmersa en una postura ético-moral de denuncia ante ciertas injusticias, ya que formamos parte de esa trama. Como cientistas sociales e investigadores-intérpretes, somos parte de una cultura que puede estar al servicio del sostenimiento de estas violencias o que, por el contrario, puede contribuir a invertirlas. Gracias a este posicionamiento político queer somos conscientes de las limitaciones que incluso pueda llegar a tener esta afirmación: concebimos a la investigación como una forma de acción política y social en la medida de que buscamos contribuir a la construcción de una sociedad más justa. Asimismo, reconocemos nuestro lugar en la disputa de sentidos y reconocemos que desde nuestro lugar de autoridad y legitimado por la sociedad podemos (debemos) hacernos cargo de estas tareas a fin de concretar un estudio orientado a complejizar la mirada sobre un fenómeno de interés reciente como lo es el auge de las comunicaciones digitales y los modos de interacción violentos y no violentos en relación con las personas LGBTIQ.

Ahora bien, la denuncia de las prácticas y de los mecanismos que perpetúan la opresión sobre sectores minorizados implica posicionarse en un lugar de investigador con una clara toma de postura política, orientada hacia análisis de esas operaciones y hacia su subsecuente transformación. Se trata sin más de hacer el ejercicio de hacerse cargo sobre para qué y por qué se investiga lo que se problematiza, decisiones que ya nos hablan de una visión particular que dista de ser neutral. Por ello debemos remitirnos a las mediaciones implicadas en el quehacer de la investigación y en la constitución de la subjetividad de quien investiga, una persona socialmente percibida como mujer, identificada como no cisheterosexual, feminista, atea, blanca, euro descendiente y a la vez latina. Luego, debemos reconocer nuestra propia relación aquellas experiencias vivenciadas como violentas. Y para esto deberíamos hablar de las discriminaciones en el espacio escolar, los malos tratos en el espacio familiar, las exclusiones en el marco laboral y los silenciamientos en el plano del discurso en general. Pero además debemos nombrar otras experiencias en las que fuimos testigos de daños acaecidos en contra de 
conocidos o desconocidos, sin pasar por alto la matanza de compañeras trans, la masacre de Orlando, las golpizas a homosexuales, pero también la criminalización de la homosexualidad en algunos países, la patologización trans, la prohibición del aborto, los femicidios, las prácticas quirúrgicas no consentidas sobre bebés intersex, las represiones policiales, las desapariciones, las detenciones ilegales, la trata, los asaltos, los bombardeos, los fusilamientos y todo tipo de atropellamiento contra los derechos humanos...

Otro elemento a considerar en cuanto a la investigación sobre las violencias en relación con las poblaciones LGBTIQ remite a la falta de investigadores dispuestos a atender estas problemáticas por falta de financiación o bien por temor a represalias a nivel laboral o por miedo a sufrir consecuencias negativas en el ámbito familiar o entre pares (Gouveia, 2005). Además, la falta de reconocimiento que por muchos años han gozado los estudios sobre géneros y sexualidades ha contribuido en la profundización de la marginación de quienes se interesan por estos tópicos; esto no solo afecta a los investigadores que siguieron ese camino sino también a quienes podrían hacerlo y no encontraron antecedentes que permitieran forjar una tradición en investigación a nivel local. Es por esto que hoy gran cantidad de los estudios latinoamericanos sobre géneros y sexualidades toman como base a autores ya consagrados de origen europeo o norteamericano, regiones en donde además ha habido más financiamiento para la realización de tareas similares y han permitido incluso la institucionalización de los estudios gay-lésbicos primero y de los estudios queer después. En América Latina, como vimos, queda mucho por hacer, aunque la incipiente incorporación de temáticas de géneros y sexualidades en ámbitos educativos y en organizaciones gubernamentales revierte esta tendencia paulatinamente.

Por último, en esta investigación hay un compromiso político explícito, lo que puede derivar en el cuestionamiento de su rigurosidad científica. Creemos que puede remediarse con el empleo de métodos y técnicas que prioricen la inclusión de las voces de los sujetos queer vinculados a los procesos que abordamos. Las personas cuyas prácticas, orientaciones, expresiones, identidades y corporalidades no coinciden con las que son cisheteronormativas han tenido poca participación en los procesos de investigación social. Más aún, su exclusión (de la ciencia y de muchos otros ámbitos) se sustentó sobre discursos religiosos primero y sobre los discursos jurídico-políticos y científicos luego. Es decir que a grandes rasgos los procesos de construcción de conocimiento científico no solo han omitido la voz de las personas LGBTIQ sino que 
también han contribuido a justificar los mecanismos de desigualación y de invisibilización por su identidad y expresión de género o su orientación sexual a través de la presencia de un componente moral(izante) orientado a mantener intacto el status quo cisheteropatriarcal. Por ello, una investigación que quiera acabar con ello deberá procurar la participación de los sectores minorizados y emplear métodos y técnicas para recuperar sus voces y sus experiencias y generar conocimientos a partir de ellas; de allí la importancia de la etnografía, de la observación participante y de entrar en diálogo con los "nativos". ${ }^{35}$ Lograr este tipo de proximidad será la mejor manera para solucionar las distancias interpretativas entre investigadores y protagonistas del proceso de investigación, como sugieren Garriga Zucal y Noel (2010).

En suma, con el propósito de visibilizar los discursos de los sujetos LGBTIQ en sus propios términos creemos que investigaciones como la nuestra deben incorporar métodos y técnicas que incluyan entrevistas para recabar los sentidos que le otorgan a aquello que denuncian como violencia, sus relatos acerca de las exclusiones y a las desigualaciones que los oprimen y sobre sus proyecciones sobre cómo transformar los espacios de exclusión en entornos más inclusivos, así como para muchos podría ser Internet. De este modo, ampliamos la voz de quienes fueron silenciados e invisibilizados por añares y evitamos imponer sentidos propios e interpretar procesos de los que solo somos observadores externos o testigos. Por lo tanto, triangularemos nuestro análisis de los comentarios y los editoriales con las voces de otros actores que entrevistamos, incluyendo las de activistas LGBTIQ en conjunto con los responsables de los blogs y de referentes políticos en el área de derechos humanos y diversidad sexogenérica.

\footnotetext{
${ }^{35}$ Es menester señalar que aquí no dialogaremos con los comentaristas de los blogs sino con sus responsables y con distintos referentes y activistas LGBTIQ para conocer su posicionamiento sobre la cuestión.
} 


\section{DESARROLLO ANALÍTICO}

En este capítulo primero desarrollamos las características de los blogs y luego realizamos el análisis de los comentarios para observar las representaciones discriminatorias sobre las personas LGBTIQ y los discursos que resisten a ellas. Acto seguido, reconstruimos cómo Clarín y La Nación representan a las personas LGBTIQ en seis editoriales en sus versiones digitales. Luego nos explayamos sobre las entrevistas que realizamos a Dema y a Bimbi para caracterizar y comparar sus roles como moderadores. También recuperamos los intercambios que tuvimos con referentes y activistas por la defensa de los derechos de las personas LGBTIQ a propósito de la actualización de la ley antidiscriminatoria. Y finalmente triangulamos la información recopilada para identificar continuidades y discrepancias entre las políticas editoriales de Clarín y La Nación y las lógicas de moderación que habilitan o no la publicación de los comentarios de los usuarios con el fin de reflexionar acerca de las tensiones entre el derecho a una vida libre de discriminación y el derecho a la libertad de expresión en Internet.

\subsection{Descripción de los blogs}

Por mucho tiempo se creyó que la comunicación mediada por computadoras podría volver horizontales las relaciones entre las personas en la medida de que desdibujaban las fronteras sociales, pero aquí no adscribimos en absoluto a ideas que aboguen por una pancomunicación ni tenemos la creencia de que todo se soluciona por, a través y en la comunicación; ni tenemos la convicción de que las tecnologías digitales posibiliten la existencia de una sociedad horizontal e igualitaria, en oposición a los postulados de autores como Manuel Castells (2001) y Daniel Cabrera (2006). Sí 
creemos que Internet como tecnología está modificando no sólo las prácticas de las sociedades sino también el modo en que nos interrelacionamos, nos comunicamos, nos organizamos y nos percibimos (De Kerckhove, 1999).

Las características de las que se tiñen las interacciones en Internet son objeto de numerosas investigaciones (Yus Ramos, 2010; Scolari, 2008; Noblia, 2004, 2009). Otros autores incorporaron una perspectiva de género al análisis de casos particulares y concluyeron que las asimetrías sexuales y las jerarquías de género se transpolan y se resignifican en los espacios digitales (Herring, 2002, 2003; Pérez Riedel, 2014). Estas asimetrías tienen relación con otras variables que escapan a nuestro análisis y que son igual de importantes que las que ya nombramos: nos referimos a las brechas de género que abarcan las brechas económicas, tecnológicas y cognitivas que terminan por dificultar el acceso a las redes y a las posibilidades que brindan (Natansohn, 2013).

Uno de estos autores, Francisco Yus (2010), es optimista con respecto a las potencialidades interaccionales de los blogs. Los define como:

Una página web que consiste en una serie de entradas hechas por un autor, o bloguero. Las entradas están organizadas cronológicamente en sentido inverso (la última aparece en primer lugar) según fecha y hora, de forma parecida a un foro de debate... Normalmente las entradas consisten en el texto de la entrada, un título y una marca de hora/fecha de publicación. Sólo las entradas más recientes aparecen en la página principal del blog mientras que las entradas más antiguas suelen recopilarse en un archivo para su acceso más adelante. En la actualidad, muchos blogs también permiten al lector mandar comentarios a entradas individuales, tal y como harían en los foros de discusión (Vuorinen, citado en Yus, 2010: 120. Bastardillas en el original)

Francisco Yus propone pensar a los blogs como un género en sí mismo en tanto poseen rasgos particulares que están convencionalizados y que en el uso se han estabilizado; desde luego que esto depende del contexto y puede estar sujeto a cambios. Pero en líneas generales, dice, hay un esquema interiorizado sobre cómo son los blogs: tienen un contenido, una finalidad y un estilo comunicacional. Los blogs prototípicos son espacios creados para la interacción con los usuarios y con otros sitios; tienen un diseño, un color de fondo y tapiz, secciones, tipos de letras y formatos, etiquetas, un autor o responsable claramente identificable, entradas, enlaces, archivos y anuncios. Tienen un fuerte potencial para fomentar interacciones con bloggers y con lectores, ya 
sea en el espacio del blog o de forma interactiva con otros canales de comunicación alternativos. Esta interactividad debe estar promovida por el bloguero, para crear sentido de pertenencia y de comunidad con los interesados en su blog, pero agrega que estos sentimientos de pertenencia a una comunidad rara vez se trasladan hacia afuera de los sitios web. Y si bien el autor no se ocupa de estudiar los conflictos que acontecen en las redes, concluye en que los usuarios de la Web 2.0 tienen tantas posibilidades de producir contenidos y de participar en intercambios en la web como los bloggers, como vemos que sucede en la sección de los comentarios de Boquitas pintadas y Tod@s.

Según Octavio Islas (2013), el primer blog data de 1992. Hacia 1998 existían solamente veinte blogs, algo que creció lentamente hasta 2002. En este período inicial, aparecieron las primeras herramientas de publicación y edición de blogs, como Pitas y Blogger. En cambio, en la segunda etapa, entre 2003 y 2007, los blogs se multiplicaron de manera sostenida. Se registraron 4 millones de blogs en 2004 y 20 millones el año siguiente; en 2007 hubo alrededor de 70 millones de blogs, con el nacimiento de 120 mil blogs nuevos por día. Según Islas, esto sucedió por dos motivos: la aparición de Google y la guerra de Irak. En el primer caso, la empresa compró a Blogger en 2003; el segundo se lo atribuye a la censura que ejerció el gobierno de George W. Bush contra los periodistas que buscaban informar acerca de la guerra de Estados Unidos contra Irak, quienes vieron en los blogs una forma de evadir esas restricciones. Por ello, Islas atribuye la expansión de la blogósfera a la aparición de numerosos blogs destinados a crónicas, relatos y análisis informativos respecto a este conflicto bélico.

El tercer periodo se extiende desde 2008 hasta la actualidad, donde se advierte una desaceleración en el crecimiento de los blogs. ${ }^{36}$ Sin embargo, observa que hay informes y registros disímiles que parecen intentar ocultar este decrecimiento y que incluso modifican los parámetros y criterios de contabilización, lo que no permite dar con una cifra exacta que dé cuenta de estos cambios. Al menos en 2010 se estimó que había 133 millones de blogs, pero se desconoce cuántos estaban activos y cuántos inactivos. También se dijo que la mayoría de los bloggers son hombres y que la mitad de los blogs son estadounidenses. Otras fuentes nos indican que en 2011 hubo 173 millones de bitácoras en línea y 152 millones en $2013 .{ }^{37}{ }^{38}$ Hoy las cifras son inexactas,

\footnotetext{
${ }^{36}$ Recordemos que el capítulo aquí citado se publicó en 2013.

37 S/A (2011) "Number of blogs worldwide from 2006 to 2011 (in millions)", Statista, the statistics portal. Disponible en http://www.statista.com/statistics/278527/number-of-blogs-worldwide [Consultado el 1 de febrero de 2016]
} 
pero se sabe que se publican más de cuatro millones de entradas por día en Internet, que hacia fines de 2015 contaba con más de tres mil millones de usuarios, y que se siguen sumando nuevos.

Por último, Islas señala que estamos asistiendo al auge de Twitter, que ya en 2008 tenía gran popularidad. El microblogging avanza a costas de los blogs; de hecho, en los últimos años estos han mostrado sus limitaciones: frente a la creencia de que eran revolucionarios, que se convertirían en la panacea de la comunicación interactiva y que constituían el medio de comunicación más importante desde la invención de la imprenta, se observó que la participación colectiva estuvo limitada al posteo de comentarios. El rápido crecimiento de las redes sociales ofrecía alternativas que los formatos de los blogs tampoco podían equiparar; además, ve que no hay blogs con contenido de calidad que sean rentables para las empresas ni para los mismos blogueros, ya que no logran tener éxito con facilidad y sus bitácoras caen en desuso. En cambio, Twitter favorece la inmediatez de la transmisión de contenidos y difusión de información hegemónica o alternativa, tal como habían hecho los blogs. Así, el autor ve que las propiedades iniciales de los blogs se encuentran hoy en una versión "mejorada" de los mismos.

Todas estas cuestiones nos permiten pensar sobre qué relevancia pueden tener dos blogs LGBTIQ de dos multimedios argentinos, sobre qué lugar ocupan estos blogs dentro del mapa de medios digitales y no digitales y si estos son espacios residuales que los multimedios crearon para abordar tópicos que no quieren tratar en los medios con mayor visibilidad. Retomaremos todos estos interrogantes más adelante. Por el momento podemos afirmar que Boquitas pintadas y Tod@s son blogs con las cualidades prototípicas que enumera Yus. Los periodistas Bimbi y Dema replican los contenidos que producen en distintas redes sociales utilizando sus cuentas personales de Twitter y Facebook, y que los usuarios participan en esos sitios del mismo modo, desde el blog o desde sus perfiles en las redes sociales. A continuación nos explayamos sobre la descripción de cada blog a partir de las observaciones que hicimos en enero de 2016.

\footnotetext{
38 GAILlE, B. (20 de noviembre de 2013) "How many blogs are on the Internet", WPVirtuoso. Disponible en http://www.wpvirtuoso.com/how-many-blogs-are-on-the-internet [Consultado el 1 de febrero de 2016]
} 


\subsubsection{Boquitas pintadas}

En primer lugar, BP nace en 2010, meses después de la sanción de la Ley de Matrimonio Igualitario. Su primera entrada se publicó el 28 de diciembre de ese año. Se puede ingresar a él desde el enlace Blogs que se sitúa en debajo de los artículos de opinión en el sitio del diario digital La Nación, desde la página de LN Blogs o desde los enlaces que su responsable, Verónica Dema, publica en su cuenta de Twitter y Facebook o en la página de Facebook del blog. Una vez en la página, vemos una imagen de cabecera que muestra a la bandera del Orgullo LGBTIQ flameando en el cielo. Sobre ella, en un pequeño rectángulo en la parte izquierda, vemos el nombre del blog en color azul, Boquitas pintadas, y abajo el slogan, “... un blog gayfriendly” (ver Figura I) Debajo de la foto, hay dos pestañas de navegación también situadas en la izquierda: Inicio y Glosario de diversidad sexual. A la derecha, hay un buscador y un ícono de sindicación o RSS.

\section{Figura I}

Homepage de BP

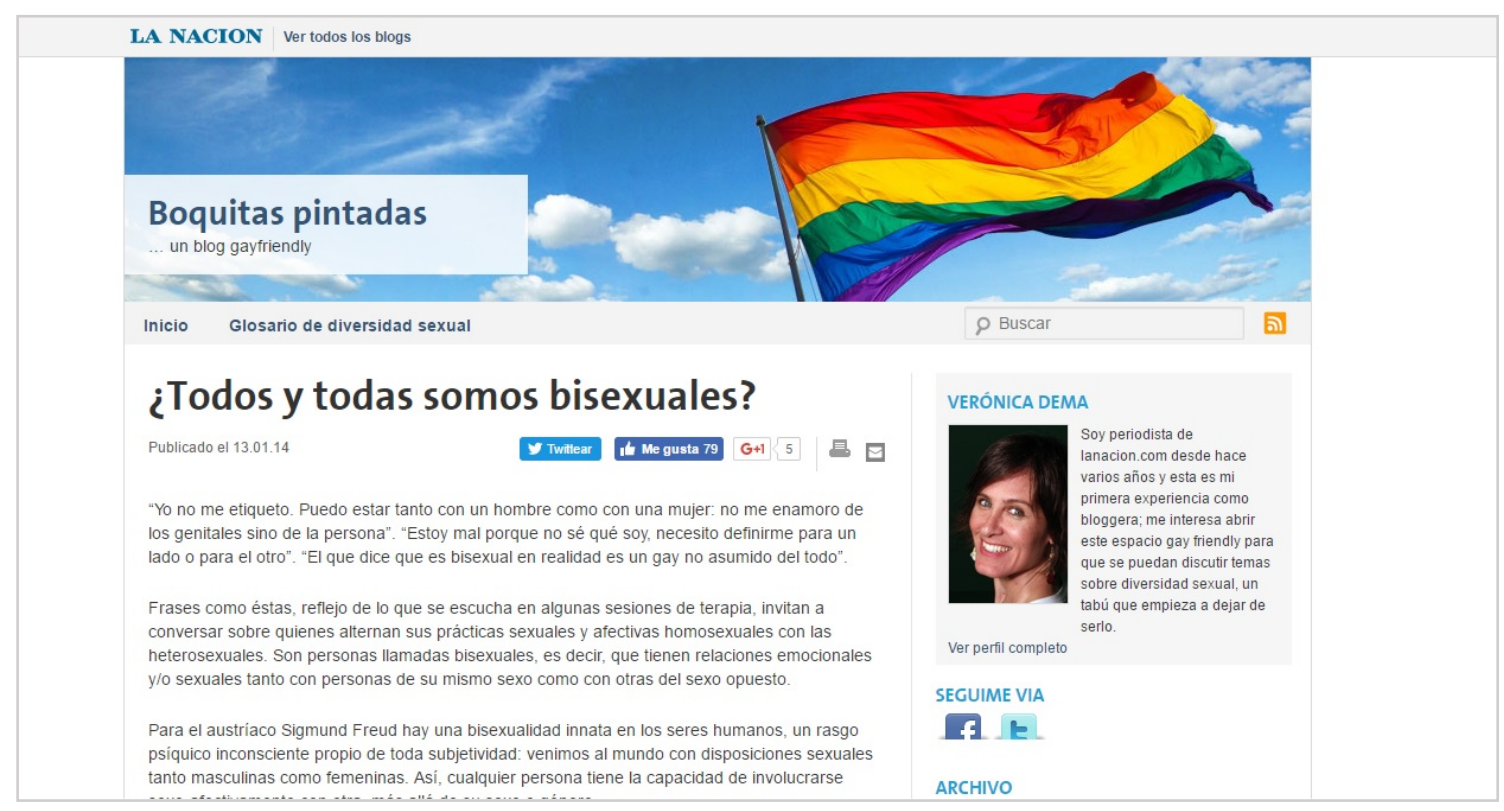

Fuente: captura propia

El tapiz del blog es de color blanco. A la derecha hay una columna donde encontramos un cuadro en un tono gris claro con el nombre de la periodista a cargo del blog, su foto y su presentación, que dice: "Soy periodista de lanacion.com desde hace varios años y esta es mi primera experiencia como bloggera; me interesa abrir este 
espacio gayfriendly para que se puedan discutir temas sobre diversidad sexual, un tabú que empieza a dejar de serlo". Hay un hipervínculo para ver el perfil completo pero al seleccionarlo nos lleva a un enlace roto. Debajo leemos la leyenda "Seguime vía" con los íconos sociales de Facebook y Twitter. También hay un archivo, una lista de categorías y otra con los últimos comentarios, donde se indica el nombre del usuario, parte de su escrito y la fecha de su publicación. Si seguimos descendiendo, encontramos el título "Blogroll" donde aparece una larga lista de sitios de interés, que incluye enlaces a páginas de organizaciones por los derechos de las personas LGBTIQ, el INADI, sitios informativos LGBTIQ y otros blogs. En la misma columna vemos que hay dos publicidades: una de Carrefour y una de Shopping La Nación.

En la solapa Inicio hay una columna principal, que ocupa dos tercios de la pantalla. En ella se muestran los artículos en un orden cronológico inverso, del más reciente al más antiguo. Los posteos tienen un título en un tamaño que triplica el del cuerpo del posteo y se muestra su fecha de publicación. Ellos incluyen fotografías con epígrafes y videos embebidos. Como cierre, en cada artículo encontramos dos leyendas que invitan a que el usuario participe y siga las novedades. Dicen: "Te invito desde este espacio a que compartas tus historias, tus experiencias. Escribí a boquitaspintadas@lanacion.com.ar. ¡Te espero! „Gracias!” (resaltado en el original) y “* RECUERDEN QUE SI QUIEREN SEGUIR LAS NOVEDADES POR FACEBOOK, ENTREN AQUÍ Y CLICKEEN EN EL BOTÓN DE "ME GUSTA" ¡GRACIAS!” 39 Las palabras "ENTREN AQUI'” son un hipervínculo que conduce a la página de Facebook del blog. Debajo, aparecen la cantidad de comentarios de cada artículo, el botón para compartir vía Twitter, el ícono de Facebook y la cantidad de "Me gusta" y el de Google+ y la respectiva cifra. Si seguimos descendiendo, vemos las notas anteriores y si llegamos al final de la pantalla, hay un link para ver las entradas más antiguas. Además, en el pie, está la información de copyright de La Nación. Si abrimos una entrada, nos encontramos con que después de las frases que citamos en el último párrafo y antes de mostrar los comentarios, se indica en qué categorías se publicó, quién la posteó y qué etiquetas le asignó.

Al hacer clic sobre la solapa superior que contiene el glosario sobre diversidad sexual, notamos que posee un estilo diferente al de las entradas de la página principal,

\footnotetext{
${ }^{39}$ El uso del formato en negrita y de las mayúsculas en Internet suele responder a intención de llamar la atención. Según el contexto, las mayúsculas y los signos de exclamación también pueden significar gritos o agresión, pero el uso de la segunda persona en plural y la modalización del discurso llevan a pensar que este no es el caso.
} 
ya que no tiene una fecha de publicación ni un cierre. Esta sección es, como dice el primer párrafo, un espacio para dar a conocer las definiciones de las siguientes palabras: LGBT, Lesbiana, Gays/homosexuales, Bisexuales, La letra T, Travestis, Transexuales, Intersexuales, Cisgénero, Clóset/armario, Andrógino, Arcoíris, Drag Queen, Drag King, Género, Heterosexual, Heteronormatividad, Homofobia, Homoparentalidad, Identidad de género, Orientación sexual, Sexo biológico, Sexualidad y Transformista. Luego se citan las fuentes con sus enlaces: “Manual de Comunicación LGBT' de ABGLT, Asociación Brasileña de Lesbianas, Gays, Bisexuales, Travestis y Transexuales y blog de Alejandro Viedma”. También se puede comentar esta entrada; el 30 de enero de 2016 vimos un total de ocho comentarios en los que algunos usuarios expresaban su desacuerdo con el uso del término "gayfriendly" o con la selección del nombre del blog, mientras que otros felicitaban la iniciativa.

Por otro lado, los comentarios utilizan la herramienta web Disqus, que es un servicio de alojamiento y moderación de comentarios que se utiliza también en Tx (ver Figura J):

\section{Figura $J$}

\section{Sección de comentarios de BP}

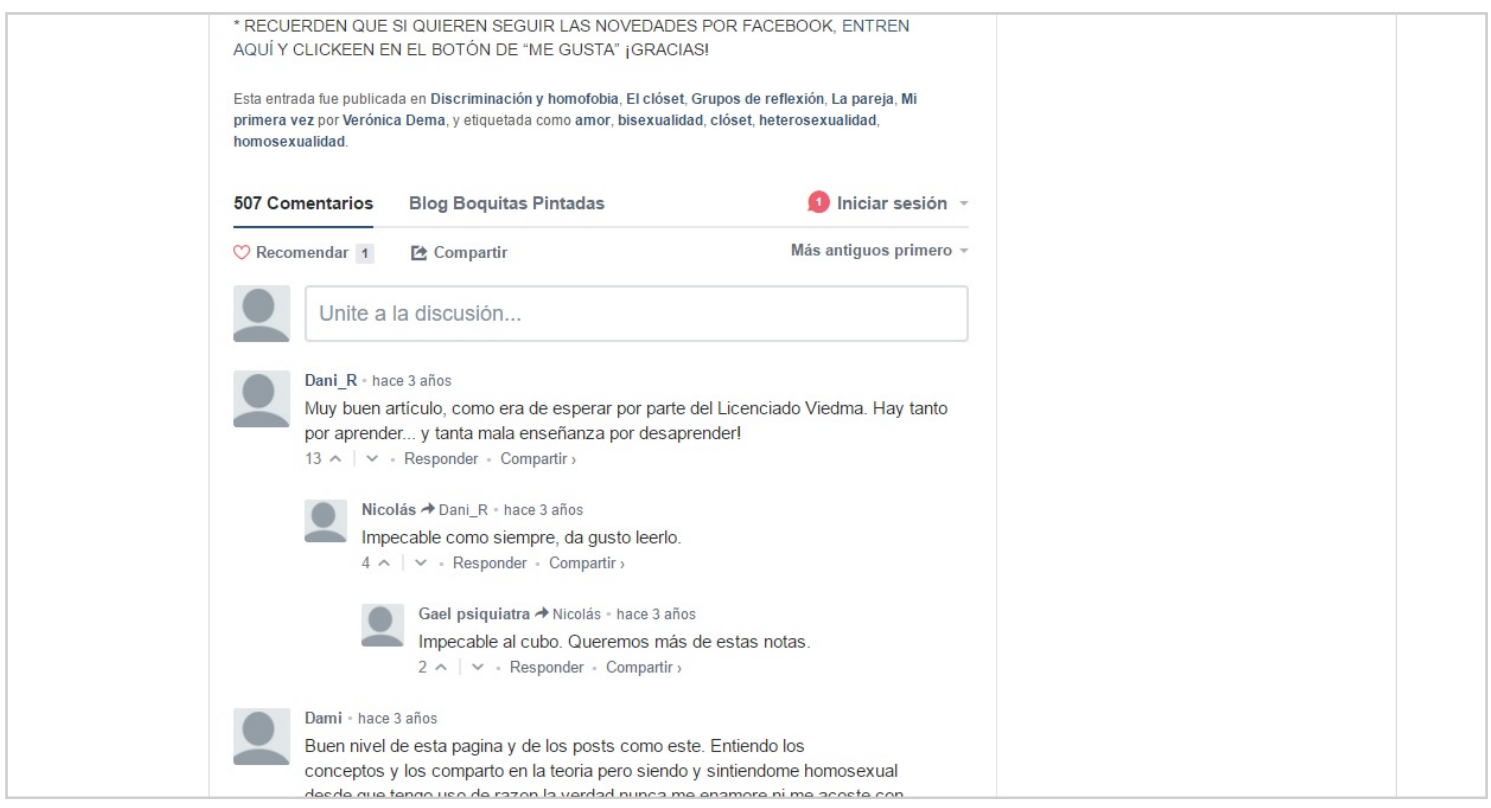

Fuente: captura propia

Se pueden ordenar los comentarios por antigüedad, para ver los más viejos o los más nuevos primero, o para ver los mejores. Para unirse a la discusión se puede ingresar a 
través de Disqus, Facebook, Twitter o Google+ o bien se puede publicar un comentario de forma anónima. Los usuarios pueden usar una foto de perfil si lo desean o registrarse en Disqus con su correo electrónico, un nombre o apodo y una contraseña. Todos los comentarios tienen un nombre, la fecha de publicación y una imagen de perfil, que puede ser genérica, con la silueta de una persona, o la de la red social elegida. Incluyen solo palabras escritas y links externos, pero no imágenes o videos embebidos. También se puede dar un voto positivo o negativo a un comentario, responderlo o compartirlo. Por último, se puede seleccionar un botón para recomendar y compartir la discusión vía Disqus.

\subsubsection{Tod@s}

Por otro lado, tenemos al blog Tx, cuya primera entrada se publicó el 2 de noviembre de 2011. Se puede llegar a él desde el sitio oficial de TN, bajando hasta "Lo último en blogs", o bien desde la página de TN Blogs o desde los enlaces que publica Bimbi en sus cuentas de Facebook o en su cuenta de Twitter. En la página principal de Tx se muestra su título en color blanco, Tod@s. Debajo dice "Lesbianas, Gays, Bisexuales, Trans". Quizás para reforzar la idea de que es un blog LGBTIQ, detrás hay una imagen de fondo de color violáceo con unas franjas de color rojo, naranja, amarillo, verde, azul y violeta: son los colores de la bandera del Orgullo. Sobre la imagen, a la derecha, hay un buscador, un botón de RSS y otro para compartir: al pasar el puntero por encima, nos ofrece las opciones de compartir vía Twitter, Facebook y Google+.

En la columna adyacente a la derecha, debajo de la imagen de presentación, se destaca un recuadro en color lila con la foto de Bruno Bimbi en primer plano, su nombre y su presentación: "Periodista y doctor en Letras / Estudios del Lenguaje (PUCRio). Activista de la Federación Argentina LGBT y autor de los libros "Matrimonio igualitario" (Planeta, 2010) y "El fin del armario" (Marea, 2017). Corresponsal de Todo Noticias en Brasil” (ver Figura K). ${ }^{40}$ No aparece su correo electrónico ni tampoco encontramos publicidad. Debajo hay un botón para recomendar el blog vía Facebook. Abajo, una lista de los últimos posts, una lista de categorías y una nube de etiquetas o tags con el rótulo "Temas". Allí se destacan las más utilizadas en un tamaño de letra

\footnotetext{
${ }^{40}$ Esta presentación data de marzo de 2017 visto que en la presentación anterior de enero de 2016 decía que era "doctorando" y no hablaba del segundo libro.
} 
más grande; ellas son: Argentina, Brasil, gay, homofobia, matrimonio igualitario, política y religión. Más abajo, una lista con "Lo último en TN", con los titulares y los enlaces a las noticias publicadas recientemente en el sitio de Todo Noticias. Y debajo de ella, un gadget de Facebook con una imagen de la página de Facebook de TN y sus últimas publicaciones.

\section{Figura $\mathrm{K}$}

Homepage de Tx

\begin{tabular}{|c|c|}
\hline 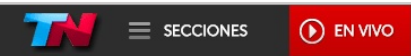 & - cuma $\mathrm{O}$ Q 1 \\
\hline TODa & 匹 Compantir \\
\hline
\end{tabular}

\section{El Papa pide perdón a los homosexuales}

Por Bruno Bimbi | 1 de enero de 2012 | 20:26

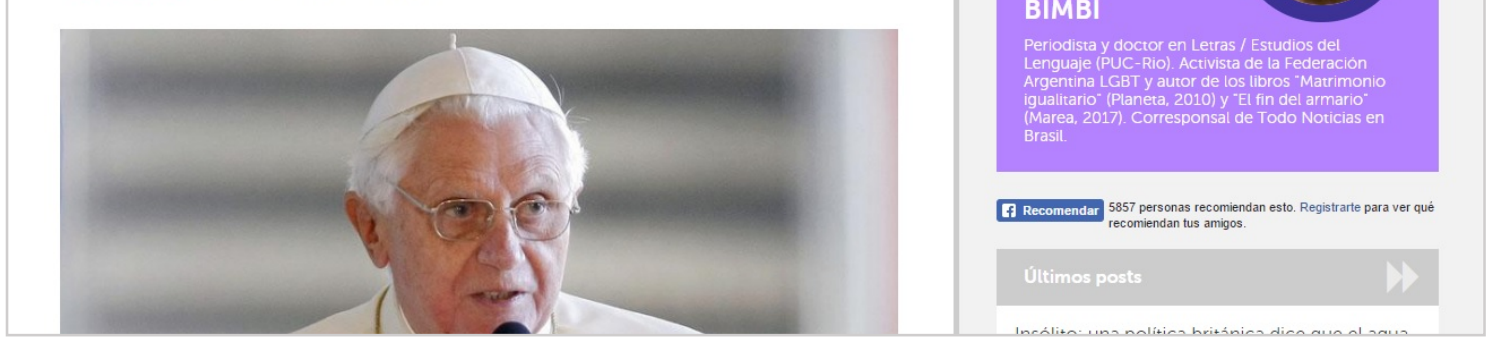

Fuente: captura propia

El tapiz del sitio es color gris claro. En la columna principal, que ocupa dos tercios de la pantalla, aparecen las entradas, que están ordenadas en un orden cronológico inverso. Sus contenidos incluyen textos e imágenes fijas y en movimiento; algunos poseen enlaces a sitios externos o a artículos anteriores. Tienen un título escrito en color violeta oscuro, con un tamaño más grande que el de la letra del texto. Además dice el nombre del autor y la fecha y hora de publicación. Debajo de cada post hay una leyenda que invita a difundirlo y dice "Si te gustó el post, compartilo en Facebook, Twitter, etc." (cursivas y destacado en el original). Y debajo de esto, dice "Mi cuenta en Twitter: @bbimbi / Facebook: Bruno Bimbi. Periodista" (cursivas en el original; el destacado aparece en color fucsia). Más abajo figuran las etiquetas, los íconos para compartir vía Twitter, Facebook y Google+, la frase "Enlace permanente", cuyo hipervínculo conduce al link estable, y la cantidad de comentarios publicados en cada posteo. Si seguimos descendiendo, vemos las entradas anteriores y, finalmente, en la 
parte inferior de la pantalla, un botón que dice "Siguiente" para ver los artículos más antiguos.

Al ingresar a cada entrada para observar la lista de comentarios, vemos que estos utilizan la herramienta web Disqus, al igual que BP. Podemos ordenar los textos con distintos criterios: los mejores, los más nuevos o los más antiguos. Ellos pueden incluir solo texto escrito o también imágenes, videos y links externos o embebidos. Se puede publicar comentarios por medio de la plataforma del blog, a través de Disqus o de las tres redes sociales que ya mencionamos. Aquí también está habilitada la posibilidad de publicar comentarios de forma anónima como invitado o guest, sin necesidad de registrarse. Los comentaristas pueden utilizar un avatar o foto de perfil, un correo electrónico y un nombre, que puede coincidir con su nombre de pila o no, o bien puede ser un seudónimo o nickname. Se pueden registrar a Disqus con su e-mail, su nombre y su contraseña, aceptando las condiciones de uso. Pueden leer los comentarios de otros usuarios, votarlos positiva o negativamente, responder a ellos y conocer en qué fecha los publicaron. Y se puede recomendar y compartir la discusión o bien ingresar a los foros de TN Blogs con los enlaces que se ubican debajo de cada entrada (ver Figura L).

Figura $L$

Sección de comentarios de Tx

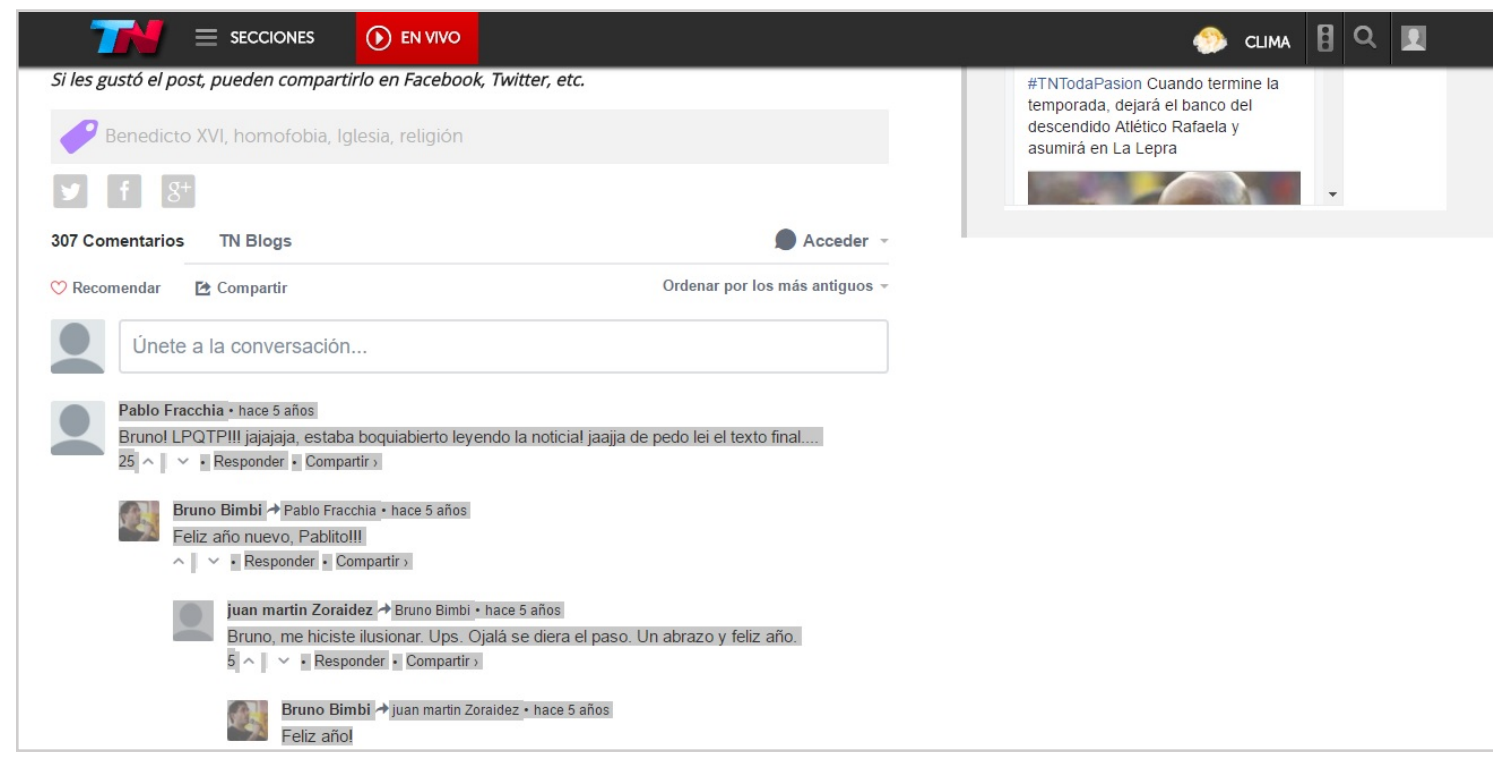

Fuente: captura propia

Abajo de todo, se muestran comentarios que otras personas publicaron en otros blogs de TN, aparecen las opciones de suscribirse a Disqus y de ver las condiciones de 
privacidad. Debajo, sobre un recuadro de color gris oscuro, el ícono de TN Blogs y la lista con los nombres y slogans de cada uno de los blogs. En la parte inferior, sobre un fondo de color negro, se ven los datos legales de la empresa, como la dirección, el número de teléfono, el correo electrónico, los términos y condiciones de uso e información sobre protección de los datos personales. Por otro lado, al desplazarnos por el sitio de arriba hacia abajo, permanece inamovible un recuadro oscuro en la parte superior de la pantalla, que tiene en la parte izquierda el logo de TN y un enlace al sitio oficial. Hacia el centro, un menú desplegable con las secciones, categorías, servicios, programas y apps, y un botón rojo para ver la transmisión en vivo. A la derecha, un ícono con el tiempo del día y la palabra "Clima", un botón para ver el estado del tránsito, un ícono con una lupa, que despliega un buscador, y por último un avatar con una silueta de un hombre, que es el genérico para los usuarios que no seleccionaron una foto de perfil. Si se selecciona ese ítem, se puede iniciar sesión con un nombre de usuario y una contraseña para conectarse a "TN y la gente". 


\section{2. “Que asco son!!!": representaciones discriminatorias y violentas contra las personas LGBTIQ}

En esta sección analizamos las representaciones discriminatorias y violentas acerca de las personas LGBTIQ en los comentarios publicados en BP y en Tx entre 2012 y 2015. En cada espacio identificamos que se desarrollan intercambios dialógicos cuyas temáticas guardan similitud con las del post en los que se inscriben, si bien los usuarios expresan su adhesión o rechazo al posicionamiento de Dema o Bimbi y a los de otros comentaristas. Vemos que en cada sitio se detentan prácticas discriminatorias que violentan a las personas no cisheterosexuales y se perpetúan los mecanismos que conducen a su exclusión, no sin resistencias. Aquí recuperamos los comentarios y analizamos sus contenidos con las técnicas y los métodos enunciados a fin de reconocer cómo se nombra a las personas LGBTIQ, qué valoraciones circulan sobre ellas y sobre sus demandas y reivindicaciones y qué estrategias argumentativas o topoi se utilizan para justificar las atribuciones negativas sobre este colectivo.

\subsubsection{Boquitas pintadas}

En primer lugar, observamos que los comentarios en BP se enfocan no tanto en los temas centrales de los artículos sino más bien en los macrotemas que abordan. Por ejemplo, en ““Anita y sus dos mamás', un cuento infantil para pensar las familias diversas" (19/11/2013), en lugar de hablarse sobre la obra literaria, se habla sobre la homomater y paternidad, el matrimonio, la familia, la sexualidad, la infancia y los derechos conquistados y vulnerados. Estos macrotemas se sostendrían en las intervenciones de otros artículos, como "30 años de democracia y 10 conquistas de la comunidad gay y trans" (09/12/2013), donde se versa sobre la Ley de Identidad de Género, las infancias trans y el caso de Lulú, una niña trans que recibió su nuevo DNI con su identidad de género autopercibida a los seis años. A veces esos comentarios guardan correlación con otros asuntos, como política, religión y la educación. Luego, notamos que estos textos siguen una lógica conversacional en la medida de que se da cuenta de una postura personal y de la distancia o proximidad a la perspectiva de sus interlocutores. Asimismo, encontramos huellas o marcas de la oralidad que se plasman en este modo de participación asincrónica y vemos que existe cierta acumulación 
temática ya que los comentarios más recientes suelen responder al tema o a los temas presentados por los interventores anteriores.

Con respecto a los postulados discriminatorios y violentos del blog de Verónica Dema, creemos que el siguiente comentario los sintetiza:

[BP44] Martín: Me parece horrible que un diario tan prestigioso como La Nación decide empezar a apoyar al lobby gay, lobby condenado por el Papa Francisco, que ahora todos admiran. Señores, esto es hacer lobby. Esto es hacer propaganda a favor de algo que es contra natura (y no contra cultura). La homosexualidad está mal. Es una desviación. No puede ser tan difícil de entender. Nacemos de determinada forma, con cromosomas que determinan si somos varones o mujeres, y no intermedios dudosos. La naturaleza no va a perdonar esto. Ya nos va a llegar la factura en unos 100 años, cuando por culpa de esta gente, no haya más nacimientos y se multipliquen los abortos (si señores, el lobby gay y la legalización del aborto van de la mano). Repudio total a La Nación.

La confusión de Martín entre orientación sexoafectiva e identidad de género se repitió en otros comentarios, al igual que la identificación del blog con el diario. Pero, salvando estos asuntos, observamos que el denominador común en las intervenciones en BP es sobre la disputa en torno a lo bueno y lo malo, lo aceptable y lo censurable. Así, principalmente se negocian sentidos hegemónicos y contrahegemónicos en relación con los órdenes del deseo, la moral, la corporalidad, la sexualidad y la identidad.

Ahora veamos algunos comentarios que se publicaron en el post sobre "Anita y sus dos mamás", un cuento infantil donde la protagonista tiene dos madres:

[BP31] trans-siberiano: anita y sus dos mamás... una vez mas, el credo gay nos propone una para-realidad milagrosa, mas difícil de creer incluso que el propio Génesis... verdaderamente son una secta, hasta tienen dogmas de fe. Pero eso no es lo grave. Lo grave es que exijan a la sociedad que adopte su credo minoritario como propio. En el fondo son intolerantes relativistas, y necesitan imponer su cosmovisión https://www.youtube.com/watch?v=dx4lzsmjXxI ${ }^{41}$

\footnotetext{
${ }^{41}$ Enlace a un video de YouTube titulado "Si puedes convencerme que he concebido una rata estaré de acuerdo con el aborto: Dra. Hildebrand", publicado por el usuario San Miguelillo el 31 de octubre de 2013.
} 
[BP97] Ger a Nicolás: y donde esta la discriminacion? acaso debemos dejar nuestros principios y valores solo porque una ley lo dice? Solo te falta el bigotito nazi jajaja te gustaria que saquen una ley que prohiba la homosexualidad? ustedes deberian dejar de ser gays para respetar la ley...lea un poco las pavadas qeu escribe antes. El respeto implica la tolerancia, los gays van a tener que tolerar a los que piensan que son degenerados, y los moralistas los van a tener que tolerar a ustedes. Eso es el respeto Nicolas.

[BP340] GITS-SAC: A joder con la mente de los infantes, que por ser gays tienen más derechos que el resto del mundo, incluso que los derechos del niño. Entre lo que hacen y las juventudes hitlerianas no hay mucha diferencia. A taladrarle la cabeza a los neces para pudrirlos desde bien tempranito, no vaya a ser que se den cuenta que ser gay (aún cuando es una decisión individual respetable) es un caracter no adaptativo que es incompatible con la subsistencia de la especie humana.-

En el primer texto, trans-siberiano habla de un credo gay que exige e impone a la sociedad su cosmovisión, "una para-realidad milagrosa". Según el usuario, esta secta minoritaria tiene dogmas de fe propios y está compuesta por personas que denomina "intolerantes relativistas". A continuación comparte un video de YouTube sobre el relativismo cultural para aumentar la fuerza argumentativa de su discurso. A través de la asociación de la homosexualidad con una secta dogmática se ve la representación peyorativa del autor sobre la maternidad de una pareja de lesbianas y sus juicios sobre la homomaternidad.

En el segundo ejemplo Ger contesta a Nicolás, quien anteriormente había copiado un fragmento de la Ley de Identidad de Género y afirmado que en el blog había comentarios discriminatorios que no respetaban la identidad de género de los usuarios. De la respuesta de Ger se extrae su creencia de que expresar sus valores y principios no constituye un acto discriminatorio. El usuario se expresa entre risas para inferir que la postura de su interlocutor es nazi y califica a sus palabras como pavadas para luego agregar que los gays que deberían dejar de serlo y deberían respetar la ley. Asevera qué es el respeto y la tolerancia y afirma en modo imperativo que "los gays van a tener que tolerar a los que piensan que son degenerados" y viceversa. Tomando la parte por el todo, Ger habla de gays cuando anteriormente se estaba hablando de identidad de género; construye una figura de un "otro" gay degenerado e intolerante que es distinto a un "nosotros" que se diferencia de ellos por tener moral. Luego, pone en circulación 
sentidos críticos con respecto a esta ley a fin de cuestionar e impugnar su legitimidad y a la vez se distancia del posicionamiento de Nicolás.

En el tercer caso, GITS-SAC se refiere a las familias homomaternales, que a diferencia de aquellas que no están constituidas por gays, buscan pudrir la mente de los infantes, menoscabar sus derechos y esconder el hecho de que la homosexualidad es "incompatible con la subsistencia de la especie humana", algo que el autor del texto compara con las juventudes hitlerianas. Dice que los gays por ser gays "tienen más derechos que el resto del mundo", si bien para él la homosexualidad es una decisión y es respetable. En otros comentarios se repetirá el argumento de que las familias diversas no se interesan por los derechos de los niños que adoptan, reiterándose una representación de un infante pasivo que es afectado por los adultos gays y que debe ser protegido de ellos. Al apelar a la noción de una infancia vulnerada se refuerza un sentido de sensibilidad social que antepone un sector social ante a otro y que presenta como contrapuestos los derechos de ambas partes, lo que conduce a priorizar a ese sector que se presupone indefenso y a desprestigiar a las personas homosexuales en su nombre. Esto se acentúa con la asociación entre los gays y la ideología nacionalsocialista, aunque la comparación es más bien paradójica: el régimen alemán tenía un plan sistemático de exterminio de diferentes grupos sociales, entre los que había homosexuales; y ahora este usuario equipara a los gays con los mismos responsables de su aniquilación.

En los tres casos los topoi de historia, legalidad, realidad, comparación y amenaza sirven de sustento para las argumentaciones de los participantes en cuestión. Ellos vinculan a la homosexualidad con ideologías dogmáticas próximas al nazismo, lo que nos lleva a pensar en el concepto de "ideología de género" tan criticado por Juan Carlos Monedero (hijo) en su libro Lenguaje, ideología y poder (2016). El autor sugiere que hay promotores homosexualistas que difunden una ideología de la no discriminación y que resignifican la palabra "discriminación" de modo tal que llevan a olvidar la verdadera denominación del término. Según él, el lenguaje en sí mismo es discriminatorio, pero no toda discriminación o distinción es injusta. Las personas homosexuales y su lobby buscan hacer que toda discriminación sea considerada injusta, aunque para el autor lo único injusto fue la aprobación del "gaymonio" o seudo matrimonio gay, en la que una minoría promiscua y contranatura presionó a legisladores e impuso su cosmovisión y sus valores sobre una mayoría, declarándole la guerra a la naturaleza humana. Esto incluye la defensa del aborto, el ataque a la familia y el 
rechazo de la palabra de Dios. Agrega que ahora el poder lo tienen las personas homosexuales, que además acusan de homofóbicos a quienes "estamos obligados a sostener la verdad y a ser intolerantes con el error" (2016: 81). Más aún, estos tiranos relativistas estigmatizan y criminalizan las palabras y las deslindan de su sentido original y las vacían de su significado para quebrar la capacidad de entendimiento y de discernimiento de las personas, para volver iguales cosas que no lo son. De este modo, según Monedero, la sociedad se aleja de un orden natural dado y se distancia cada vez más de la palabra de Dios.

Con palabras similares, algunos comentaristas hablan negativamente sobre la ideología o mito de género, utilizada por parejas homosexuales para adoctrinar a sus hijos y lavarles cerebro, como se dice a continuación:

[BP27] cable-opinión a Gerardo Medina: y los adoctrinarán desde pequeños en el mito del genero, disociado de la persona. Como si la sexualidad fuera un traje, lo uso, lo cambio, agarro otro... pret a porté... Imaginate que si a un pibe el divorcio de los padres le parte el alma en dos y le genera un trauma existencial ¿como puede crecer un pibe al que desde la cuna le lavan el cerebro conque tu familia son mamá y mamá? o que eso es diversidad? tenés varios sabores, pan con pan, queso con queso, salchichon con salchichón, elegí! en el fondo NO DEJAN de ser adultos obrando arbitraria y caprichosamente con los niños

La asociación de la homosexualidad con un gobierno dictatorial lleva a reforzar la proposición de que los gays imponen sus ideas a la fuerza sobre el resto, especialmente sobre los infantes. Por otra parte, se refiere a la sexualidad como algo fijo e inmóvil y a la diversidad con distintos sabores. Después se afirma que a los niños el tener madre o madre, o padre y padre, les genera traumas similares a los de divorcio. Porque, como agrega el siguiente lector, las familias se componen con un padre y una madre; negar a los hijos la existencia de uno equivale a hacerles daño intencionalmente, tal como hace(n) con egoísmo la(s) mamá(s) de Anita. Los topoi de peligro y de desventaja se hacen presentes en el texto de arriba como en el que sigue:

[BP1] Gerardo Medina: En realidad una sola de las mujeres es la madre, la otra es la "pareja" de la madre y nada mas. Lo mas tragico de esto, y pensando en las criaturas que viven en este tipo de "familias", es que nunca jamas sabran lo que es tener un padre al lado, todo el aporte para un niño que representa crecer con un padre a su lado no lo tendrán, y eso es un daño hecho adrede al niño o 
niña...porque no hay adulto que pueda negar que habiendo crecido con padre y madre, si le arrancaran la figura paterna durante su niñez, eso hubiera significado un gravisimo(y talvez irreparable) daño para ellos. Cuando dejamos de priorizar a los niños en la crianza, para centrarnos en el egoismo personal de los adultos?

Analicemos más ejemplos:

[BP423] Realidad: QUE PACIENCIA TIENEN CHE, SABEN QUE PERDIERON LA GUERRA PARA QUE LA SOCIEDAD LOS ACEPTE PERO SIGUEN INTENTANDO. MUY BIEN! JAJA

[BP754] Morita19: Siempre, pero siempre, cuando de un lado hay ganadores, del otro hay perdedores. Ganan los travestis=pierde la sociedad normal. Pierde la familia. Pierden los niños. Pierde la educación. Pierden nuestros abuelos que han invertido en educación, principios, respeto, para fundar un país grande, que se va por la letrina, como consecuencia del egoísmo de unos pocos desequilibrados y perversos sexuales (como bien dijera Freud). Una derrota a la gente.

El primer comentario se extrae de nuevo del post sobre "Anita y sus dos mamás" y el segundo del artículo que se titula "30 años de democracia y 10 conquistas de la comunidad gay y trans", donde se repasan los avances en materia de derechos de las personas LGBTIQ. Ambos usuarios coinciden en la existencia de dos grupos, uno de ganadores y uno de perdedores. No obstante, colocan en diferentes lugares a las personas LGBTIQ, homosexuales o travestis según el caso. Realidad, en nombre de la realidad y con mayúsculas para enfatizar su postura, habla de una guerra que perdieron los "otros" no heterosexuales. La sociedad, de la que "ellos" no forman parte, no acepta la homosexualidad a pesar de sus intentos por lograrlo. Pero en el segundo texto Morita19 posiciona a "los" travestis, en masculino, en el lugar del bando ganador. Desde su punto de vista, si unos ganan, otros pierden. Como sintetiza: "Ganan los travestis=pierde la sociedad normal". Hablando sobre las travestis quizás en nombre de toda la población trans, dice que no son parte de la sociedad normal, "la gente"; ergo son anormales, no son personas. Dice que se trata de un grupo reducido de seres egoístas, desequilibrados y perversos sexuales y hace referencia a Sigmund Freud para respaldar sus dichos con una palabra de autoridad. Entre los perdedores están la familia, los niños, la educación, los abuelos (que invirtieron en educación, principios, respeto, 
para fundar un país grande), el país y la gente. Detrás de las afirmaciones de Morita19 subyace la suposición de que los derechos consagrados por las personas trans se obtuvieron a costas y en detrimento de los derechos de quienes no los son. Aún más, las representa como seres repudiables (monstruosos si se quiere) que son culpables de la derrota de la sociedad normal, conjugándose los topoi de realidad y de amenaza. En suma, víctimas normales y victimarias trans.

La cuestión de la identidad de género se repitió en varias intervenciones, como en las que recuperamos a continuación:

[BP90] esteban.dolero a Nicolás: la identidad es una cualidad de la naturaleza humana, una condición, no una concesión. Pretender que una ley constituye la realidad, es lo mismo que postularon los NAZIS para negar el derecho de ciudadania a los judios nacidos en suelo alemán. El derecho se sustenta en la justicia, en dar a cada uno lo que le és propio, lo que le corresponde. Toda ley es tan válida como represente o distinga la realidad, no como mayorías o minorías impongan a quienes no piensan como ellos. ud puede postular legalmente que la tierra es cuadrada... eso no es ley, porque es un postulado irreal AJENO a justicia. Si ud no se respeta a si mismo tal cual és ¿con que derecho le va a exigir a otros que respeten una dudosa argumentación legal? Además que esto es un FORO DE OPINIÓN. Si vas a usar la ley para negar el derecho de libre expresión ajena, entonces la ley es INCONSTITUCIONAL. Hacete un blog cerrado, sin opiniones... además que opinar no limita, restringe, excluye o suprime el ejercicio de tu derecho a opinar... no lo hagas con el mío. [BP93] Hugo a Nicolás: Que es identidad de genero? que un tipo se crea Napoleon bonaparte? y todos deberiamos seguirle la corriente en su fantasia? esa ley no aporta nada bueno, y no representa el sentir de la sociedad, fué aprobada con trampas y a contramano de la sociedad, y será modificada en breve.

[BP740] Marcela a Nora: el DNI no define, la realidad define y el documento lo refleja ¿o ahora los papeles hacen la realidad? tan absurdo manejo del criterio de LEY es una burrada... las leyes no fijan lo bueno, las leyes expresan lo bueno. Definir por el DNI es poner el carro delante del caballo. y cuando la ley no refleja lo real, entonces no es ley, sino un postulado absurdo.

En estos textos se yuxtaponen los topoi de justicia, legalidad, derecho y realidad. De este modo, se afirma que Ley de Identidad de Género es absurda porque no refleja la 
realidad, es ajena a la justicia y se sustenta sobre postulados que son absurdos e irreales; por lo tanto, la identidad de género se basa sobre una realidad binaria, natural y biológica que debería verse reflejada en el DNI. Y como agrega Hugo, esta ley representa a la sociedad, se aprobó con trampas y será modificada. ${ }^{42}$ En consecuencia, si una ley no expresa lo bueno o lo justo o si no representa la realidad, entonces no es una ley. A la vez que se cuestiona la legitimidad y la constitucionalidad de la norma, el usuario reclama que se respete su opinión. Así, parece ser que el derecho a la libertad de expresión debe avalar por igual todo tipo de expresiones para no restringir la voz de nadie, sin reconocer que algunas opiniones pueden ser discriminatorias.

En simultáneo, encontramos comentarios que se expresan sobre la relación entre la Ley de Identidad de Género y la niñez:

[BP746] Gerardo Cino a C Méndez: A los 2 o 3 años un niño no tiene idea de nada y no esta capacitado para tomar ninguna decision importante. Usted cree que darle un dni de mujer y tratarla como si fuera mujer no es un daño? En que se basan para tomar tal decision?? en lo que diga el niño/a? por favor...seamos serios, si un niño a esa edad le pide manejar un auto en plena autopista, lo van a dejar? si le pide jugar con un cuchillo filoso, lo van a dejar? y cuantas cosas mas podria mencionar de cosas que los chicos "piden", y que corresponden a los adultos, que tenemos experiencia y conocimientos para darnos cuenta de las cosas. El solo hecho de que le hayan seguido la corriente en este delirio ya es tragico, y casi con seguridad irreversible...y lo unico que se logró es arruinarle la vida a la criatura.

Gerardo aquí se expresa sobre el caso de Luana, que se convirtió en noticia por ser la primera niña trans en recibir su DNI con su identidad autopercibida. Para este usuario Lulú, es una criatura vulnerada, un niño que no pudo haber tomado esta decisión. Los adultos que le siguieron el delirio le arruinaron la vida, pero no solo eso, sino que lo hicieron de manera trágica (topoi de realidad, desventaja y de amenaza). Agrega que a la menor no se le debería dejar que acceda a esto porque no tiene experiencia, conocimiento ni capacidad para tomar una decisión así. Compara la identidad de género con manejar en la autopista o jugar con un cuchillo filoso para banalizar la decisión y

\footnotetext{
${ }^{42}$ En otros comentarios se reitera la apreciación de que normas como estas serían derogadas con el fin de la presidencia de Cristina Fernández.
} 
para ilustrar la idea de lo dañino y perjudicial que es tratar a Lulú como si fuese mujer y darle un DNI acorde, sin reconocer la identidad de la menor.

En este blog vimos otros comentarios en los que se cambiaba adrede la identidad de género de las personas sobre las que se habla o de los usuarios que se tenían como interlocutores, como sucede a continuación:

[BP1117] Fernando Molina a Nicolás: A ver, si vas caminando por la calle y ves un gato, no hace falta un titulado en neuropsicología para que te explique que lo que viste es justamente un gato. Ahora, si todo el mundo ve un gato, pero vos Nicolás en realidad ve un perro, entonces si hace falta un profesional que te trate, es asi de simple. Ademas, por lo que tengo entendido, esto está incluido dentro de los trastornos de identidad, por lo tanto no se de que estamos hablando.

[BP1123] Fernando Molina a Karen Bennett: Estas equivocado, porque pretendés que el mundo entero te siga en tu delirio, o no?. Si vos al mirarte al espejo ves un hombre o al pato donald es una cuestion tuya y corresponde a los psiquiatras analizarlo, no a mi, pero si pretendes que todo el mundo que ve la realidad, que sos un hombre, te trate como si fueras el pato donald, por ejemplo, ya es otra cosa. Toda la gente ve la realidad de que sos hombre, solo vos, en realidad tus ojos perciben la imagen que devuelve el espejo pero tu cerebro no la procesa como en todo el resto de las personas.

En estos textos, el usuario que se identifica como Fernando Molina habla de la identidad de género como un trastorno de la identidad, como un delirio que requiere la atención de un psiquiatra. Acude a los topoi de realidad y de definición para argumentar de forma tautológica que cuando ve a Karen Bennett ve a un hombre porque ella es un hombre (y por eso la trata en masculino), pero ella no puede ver la realidad en el espejo por este trastorno que padece: el espejo puede mostrarla como mujer o como un personaje de ficción de Disney, pero eso no la convierte en ello. Tampoco lo hace creerse ni llamarse Napoleón Bonaparte, como decía Hugo anteriormente.

Cuando se representa a la identidad de género como un delirio imaginario que aproxima al sujeto a lo animal o a un personaje histórico o ficcional, se banaliza y se despolitiza la problemática y se deshumaniza, se revictimiza y se patologiza a las personas trans. Pero en el intercambio de los blogs ello también parece constituir un mecanismo para desprestigiar a los interlocutores a través del tratamiento en masculino de las mujeres trans, la manifestación de dudas (o expresión de certezas) sobre su (falta 
de) salud mental y la negación y rechazo hacia la existencia de las identidades de género y orientaciones sexoafectivas no normativas a través del empleo de nominaciones y predicaciones peyorativas y expresiones que manifiestan sensaciones de rechazo, asco o disgusto sobre las corporalidades, deseos y prácticas de las personas LGBTIQ.

Además, de las estrategias mencionadas, nos encontramos con comentarios que decían que los usuarios LGBTIQ estaban discriminando a quienes no lo eran. Más aún, se los acusaba de heterofóbicos. Debajo de la entrada "¿Todos y todas somos bisexuales?" (13/01/2014), un usuario explica qué es la heterofobia:

[BP1523] David Tonelli a C Méndez: En la Medicina, en particular en la Psicología se lo utiliza para designar el miedo al sexo opuesto. El término heterofobia también hace referencia a la aversión (fobia, del griego antiguo Фóbos, fobos, 'pánico') obsesiva contra el sexo opuesto.

https://es.wikipedia.org/wiki/Heterofobia

Como se manifiesta? asi:

¿Todos y todas somos bisexuales?= verdad indiscutible.

¿Todos y todas somos heterosexuales? $=$ noooo mentira homofobica .

o tambien:

comentario pro gay= inteligente, sensible, buena gente.

comentario antigay $=$ ignorante, insensible, horrible persona, homofobico total.

Leyendo los comentarios de los homosexuales y casi todos serian heterofobicos

Para avalar su hipótesis de que casi todos los homosexuales que comentan en el blog serían heterofóbicos, se cita de manera textual la definición de "heterofobia" que figura en la enciclopedia abierta Wikipedia y se pega el enlace. ${ }^{43}$ Pero la cita es incompleta; si accedemos al link podemos leer que la palabra puede designar el miedo al otro, a la diferencia sexual y a cualquier grupo minoritario, similar al racismo o al etnocentrismo (topos de nominación). Pero David Tonelli resignifica esta definición como un miedo a

\footnotetext{
${ }^{43}$ En este sentido, la definición de la página web se asemeja a la que escribimos anteriormente sobre la homofobia. Como se lee en el resto de la entrada de Wikipedia, [la heterofobia] "Según el psiquiatra francés Tony Anatrella, es 'el miedo al sexo contrario, a todo lo que sea extraño a su propio sexo, a la diferencia sexual, que es fuente de alteridad'. En las ciencias sociales, es utilizado para definir el miedo hacia lo distinto, la definición proviene de los términos heterofobia hetero (distinto) fobia (miedo). Desde un punto de vista sociocultural se asemeja más a conceptos como racismo, etnocentrismo y xenofobia, es decir es el rechazo, exclusión o discriminación a cualquier grupo social minoritario. Según Daniel Ferstein en el artículo Las lógicas del racismo, la heterofobia sería 'el miedo, extrañeza o confusión ante el otro, miedo que se expresa como miedo a lo desconocido y que forma parte de la propia estructura de personalidad de los sujetos sociales'. Ferstein continua diciendo que 'la heterofobia es un proceso social muy antiguo, cuyo rastreo debiera vincularse más a la exploración antropológica y psicológica de los primeros conjuntos humanos". [Consultado el 15 de julio de 2017]
} 
lo distinto, que se traduce en fórmulas dicotómicas, como por ejemplo: comentarios pro gay / comentarios anti gay. El usuario alega que los comentarios a favor de las personas LGBTIQ parecen ser aceptables en el blog, mientras que los contrarios no. Siguiendo este razonamiento, los gays piensan que quienes los apoyan son buenas personas, pero califican de homofóbicos a quienes no lo hacen. El concepto de "heterofobía" se presenta como una reapropiación que permite combatir la acusación de homofobia que reciben algunos usuarios del blog a partir de sus intervenciones escritas. La disyuntiva y la disputa entre homo / heterofobia se vuelve palpable al ver que ambos términos se utilizan como forma de ataque contra el contrincante discursivo y como tácticas de resistencia para defender los valores e ideales de un grupo de pertenencia o referencia contra aquellos que se percibe que buscan subvertirlos.

Hay otros comentarios que califican a los homosexuales y a las personas trans como heterofóbicas, pero aquí recuperamos dos más:

[BP338] Angel a C Méndez: el problema del blog no son lo que uds llaman homofóbicos, sino que uds son heterofóbicos impunemente... se cae de maduro con las respuestas... 'o sos como yo o te cago a patadas, por subnormal'... terminan siendo lo mismo que pretendían condenar.

[BP399] Guest a Karen Bennett: hay karem....si no te gustan otras opiones , entonces tenes heterofobia que tambien es una forma de discriminar. No todo el muendo tiene q ver el mundo como a vos se te canta. En todos los comentarios veo una respuesta tuya, se nota tu resentimiento.

"O sos como yo o te cago a patadas, por subnormal": para estos usuarios, las personas LGBTIQ son heterofóbicas y discriminan al que piensa distinto. Se muestran distantes del colectivo LGBTIQ y resignifican el concepto de anormalidad colocándose a sí mismos en un lugar de diferencia. Esta nueva retórica de la hetero-diferencia se emplea con propósitos de preservación del propio sistema de valores y como modo de defenderse frente a un atacante que supuestamente discrimina al que no es gay.

En suma, en BP se detentan representaciones discursivas peyorativas con respecto a las personas LGBTIQ y sus reivindicaciones. Usando las expresiones que figuran en los comentarios del corpus, se dice que las personas LGBTIQ son egoístas, histéricas, heterofóbicas, nazis, fanáticas, intolerantes, discriminatorias, delirantes y enfermas de SIDA. La homosexualidad no es natural sino que es algo cultural y se auto extingue porque no es procreativa. En líneas generales, se dice que las y los 
homosexuales son una secta, que acabarán con la existencia de la humanidad, que anteponen e imponen sus intereses frente al resto, que son desequilibrados, desviados, sociópatas, degenerados, promiscuos, anormales y perversos, y que si se vela por sus derechos habría que hacer lo mismo con los pedófilos. También se afirma que hay un lobby gay que con su patoterismo busca legalizar el aborto, destruir la familia e imponer su credo o cosmovisión contra natura para cambiar la moral, homosexualizar a la sociedad y afianzar su negación sobre una sociedad que en realidad no acepta a las personas LGBTIQ.

En este orden de cosas, las leyes que defienden sus derechos conducen a la destrucción de la sociedad ya que son leyes injustas que resultan de postulados absurdos e irreales y de la presión política ejercida por este grupo minoritario para su propio beneficio a través del adoctrinamiento de niños y la presión del lobby gay. Por último, se dice que los matrimonios entre personas del mismo sexo no son matrimonios porque dos hombres o dos mujeres no pueden procrear. Las familias diversas hacen daño a los hijos adoptivos y les generan traumas. Asimismo, el otorgamiento del DNI a una niña trans con su identidad de género autopercibida es una locura, al igual que el reconocimiento de cualquier identidad de género que se escape de la norma cisgénero.

Para finalizar, observamos que las representaciones discursivas violentas en BP son peyorativas y estereotipantes de la diversidad sexo-genérica. Se refuerzan los binarismos de género $\mathrm{y}$ las orientaciones sexuales con un enfoque biologicista $\mathrm{y}$ patologizante de la diversidad sexual, a la vez que se invierten los sentidos de ciertas palabras que históricamente fueron bastión de batalla de las personas LGBTIQ, como "discriminación" y "homofobia". Además, a ellas se las ataca en un espacio que reclaman como propio y permanentemente se disputan los límites del derecho de libertad de expresión en tanto se percibe que el blog es un espacio que existe para intercambiar opiniones, si bien esto ocurre de formas más o menos violentas y no sin resistencias. Luego, notamos que los usuarios sirven principalmente el topos de amenaza $\mathrm{y}$, en menor medida, de los topoi de realidad, historia, nominación y desventaja para afirmar que la sociedad no acepta a los homosexuales y personas trans, que sus leyes son injustas y que los suyos no son matrimonios ni familias y que en todo caso ellos constituyen una amenaza para estas instituciones y para los niños. Al respecto, se alega que el reconocimiento de los derechos de los sujetos con sexualidades y géneros disidentes va en detrimento de la sociedad "normal" y que los más afectados por esto son los niños. Entonces, las personas LGBTIQ son las victimarias y las 
personas no LGBTIQ son las víctimas, a las que se les quieren imponer la ideología de género como si fuese que se vive en un régimen totalitario filo nazi.

\subsubsection{Tod@s}

Observamos que los comentarios en Tx se centran sobre los temas de los artículos y los macrotemas que son transversales a ellos. A partir de nuestro análisis del corpus, vemos que los tópicos se vinculan principalmente con la religión y la política; en segundo lugar, con la discriminación y la violencia. Ello también lo notamos en los artículos más comentados; ellos fueron: "El Papa que huyó por amor (y se fue a vivir con su secretario" (15/02/2013), donde se escribe sobre la renuncia de Benedicto XVI y donde hubo 1.104 comentarios; y el post "Hablemos del subsidio para travestis y transexuales" (27/11/2014) donde se publicaron 842 comentarios vinculados con el proyecto de ley de María Rachid. Al igual que en BP, había cadenas de intercambios conversacionales donde los usuarios expresaban su posicionamiento o manifestaban su adhesión o su rechazo al posicionamiento de sus interlocutores.

En los comentarios pudimos identificar que había discursos sobre las personas LGBTIQ que tendían a sostener representaciones discriminatorias sobre el colectivo. Se habla de los homosexuales y las personas trans y travestis en nombre de toda la población de disidentes sexo-genérico a la vez que se invisibiliza su heterogeneidad. En primer lugar, notamos que a lo largo de varias intervenciones se las caracteriza como personas violentas, intolerantes y discriminadoras. Los comentarios que siguen se extraen del post "Daniel Zamudio" (25/03/2012), donde se habla de un hombre gay chileno gay que recibió una golpiza que terminó en su muerte. En ese posteo, Bimbi recupera un fragmento de un artículo que publicó en Crítica de la Argentina donde entrevistaba a un sacerdote sobre su postura de rechazo respecto a la homosexualidad y la compara con la de los atacantes de Zamudio para argumentar que los autores materiales no fueron los únicos culpables de la muerte del joven, sino, como dice Bimbi en el escrito, "hay autoridades religiosas y seculares, gente con cargos y poder, que piensan más o menos lo mismo [que los agresores]". Los usuarios le responden:

[TX873] Maria Laura Jauven Balderrama a Bruno Bimbi: ya es en vano bruno, me encantas sos un exelente periodista, pero ya me dio miedo, solo he recibido 
insultos y rebajas mentales, etcc, me da miedo defender a mi iglesia, mi dios, mi jesus, mi virgen, mi papa..hasta hay en un comentario que dice que le hagan lo mismo [que a Zamudio] a luis [un comentarista] a ver si le gusta, ya veo que termino muerta junto a mi hijo por los gay, la verdad estan llenos de odio y sumamente irrespetuosos, luis no opines mas y sigamos con lo que dice la biblia no vaya a ser que se les desate la locura de odio hacia nosotros por defender la iglesia que quizas nos maten....un abrazo bruno.

[TX1067] Alejandro Orellana: Mis felicitaciones Bruno, lograste desviar la discriminación sexual por discriminación religiosa ¿Estás orgulloso?. Haces lo que tu mismo criticas, una lástima tu inconsecuencia...

Lamentable, es justamente por personas como tu que no avanzamos como sociedad, y que nos remitimos al arcaico método de seguir respondiendo la violencia con violencia...

En intervenciones como las citadas arriba se dialoga sobre la relación entre la homosexualidad y la religión, con énfasis sobre el catolicismo, la Iglesia y el Papa Benedicto XVI a partir de los ejes temáticos del artículo de Bimbi y los que surgieron a lo largo de los intercambios en los comentarios. Allí, quienes defendían a las instituciones eclesiásticas aducían que se los discriminaba por sus creencias, se los insultaba y se los amenazaba. Discriminación sexual sustituida por discriminación religiosa, como señala Alejandro Orellana, quien acusa a Bimbi de responder a la violencia (por el acto perpetrado contra Zamudio) con más violencia. Los gays así son representados como seres intolerantes e irrespetuosos que están llenos de odio, como agrega Maria Laura Jauven Balderrama, dado que son violentos contra los heterosexuales y la Iglesia. Incluso dice temer por su vida y por la de su hijo por defender a la Iglesia a partir de las amenazas que leyó en comentarios dirigidos a otro participante cuyo apodo era Luis Fernando. Aquí el topos del peligro y la amenaza habilita a justificar la discriminación histórica contra los homosexuales a pesar de que se acababa de cometer un crimen de odio motivado por la orientación sexual de la víctima.

Los lectores que defienden sus creencias religiosas apoyan la exclusión de homosexuales de la Iglesia, respaldan sus dichos con la autoridad que le confieren a la Biblia y a Dios y critican el uso que se le da a la palabra "homofobia", como vemos a continuación: 
[TX292] Pablo Alexander Torres Acurero: La iglesia nunca va a aprobar el matrimonio entre homosexuales ya que la biblia la palabra de Dios es bien clara cuando dice que los homosexuales no entraran al reino de Dios y que todo esto es una aberración es abominable y una falta de respeto para Dios, así que los invito a que se lean Completa la Biblia la palabra de Dios.

[TX749] Luis Fernando a Bruno Bimbi: Yo llevo toda la vida oyendo lo mismo [que ser gay es una porquería] y jamás se me ha pasado por la cabeza levantarle siquiera la mano a alguien. Lo que pasa es que no hay nada más fácil que acudir a la evasión moral para no asumir las responsabilidades individuales. El que es malo es malo y siempre encuentra una razón para hacer sus maldades, a mí no me vengan con el cuento de que la "homofobia" (que así llaman ustedes a todo porque como a los señores gays no se les puede decir nada porque pobrecitos, qué buenos son) nació al mismo tiempo que el cristianismo porque no es así.

[TX751] Luis Fernando a Bruno Bimbi: Primero: Yo no niego que haya crímenes de odio, no solo contra los homosexuales. También los hay por motivos raciales, culturales (gitanos, por ejemplo), religiosos, xenófobos. Pero ese no es el punto. El punto es que usted responsabiliza a la Iglesia de esos crímenes, lo cual es una acusación temeraria y a todas luces falsa. Porque de la misma forma podríamos inferir que los cientos de miles de muertos que los cristianos ponemos cada año son responsabilidad de los que piensan como usted... ¿sería usted un autor intelectual?

Segundo: Diga lo que quiera, es su blog. No le tengo miedo a los insultos, a ustedes les salen a borbotones. Créame que estoy acostumbrado.Tercero: Tengo todas las razones del mundo para escribir "homofobia", porque a ustedes cualquier cosa que se les diga la consideran como tal. No se puede hacer ni chistes de gays porque ahí mismo saltan y gritan ¡homofobia!

[TX1070] Roberto Baldini: ¿¿Los asesinos [de Zamudio] leyeron el libro de la Iglesia?? ¡QQué cultos que son!!...Ataques a homosexuales hay en países católicos, protestantes, musulmanes, budistas, ateos y laicistas y anticatólicos, vg en la Cuba de Castro, la Argentina de Kirchner, China, Suecia y ainda mais. Es un sofisma teofóbico contrario a la libertad de expresión vincular este hecho de psicopatas con una posición crítica reflexiva y fundada de la homosexualidad que pueda haber realizado la Iglesia Católica y sobre todo con la crítica al ataque al matrimonio y la familia que se intenta con el matrimonoide gay en Chile, Acdemás,mi modesta opinión personal es que el matrimonoide gay aumentará y no disminuirá la "homofobia" 
Los usuarios intentan desligar el dogma religioso de la autoría intelectual del crimen de Zamudio, tal como sugería Bimbi. Ello se observa en las afirmaciones de que la Iglesia Católica tiene una mirada crítica y fundada sobre la homosexualidad y el matrimonio pero nunca a favor de la violencia en su contra. Se argumenta que el "matrimonoide gay" es aberrante y atenta contra la familia, el matrimonio y la palabra de Dios (topos de amenaza). Pero los usuarios no reconocen que la exclusión de las personas LGBTIQ y la negación de sus derechos puedan ser percibidas como hechos violentos. Luis Fernando alega que los católicos no son violentos y da vuelta el discurso de Bimbi para preguntar si los "cientos de miles de [cristianos] muertos" serían autoría intelectual de quienes piensan como el periodista. Además indica que los homosexuales no son las únicas víctimas de los crímenes de odio y, como agrega Roberto Baldini, los gays son muertos en países con distintas religiones y regímenes políticos. De este modo, se rechaza el "sofisma teofóbico" de que el cristianismo o el catolicismo respaldan material o simbólicamente la matanza de homosexuales hoy. Según los comentaristas, este tipo de sucesos en todo caso responden a psicopatías individuales y es falso suponer que la Iglesia o Dios son responsables de ello, ignorando la problemática social que habilita la proliferación de crímenes contra la población LGBTIQ. Paralelamente, refuerzan la representación de una disidencia sexual violenta dado que comete atentados contra los pilares de la sociedad, en contra de la Iglesia y en contra de sus creyentes. Las acusaciones de que los homosexuales son teofóbicos y que discriminan y amenazan a los religiosos mitigan la posible articulación entre la palabra de Dios y el crimen de Zamudio y, con él, otros crímenes de odio contra las personas LGBTIQ. También desligan la culpa y la responsabilidad que se les podría atribuir a algunas autoridades eclesiásticas por promover la marginación de este sector y mitigan la gravedad del asunto al decir que los homosexuales no son los únicos que son víctimas de crímenes dado que dice que hay cientos de miles de muertos cristianos.

Por otra parte, vemos que en este contexto el uso de la palabra "homofobia" resignifica y subvierte el sentido político que históricamente le han dado los movimientos LGBTIQ en rechazo a la discriminación y violencia heteronormativa que padecieron por siglos. Así, se dice que ese término abarca todo aquello que se diga en contra de los homosexuales, como si fuese un rótulo que se le da a todo lo que los afecte y que entonces no se les puede criticar nada. Roberto Baldini incluso pone entre comillas el término "homofobia" como un modo de trastocar la autenticidad del mismo, a la vez que señala que esta irá en aumento gracias a la aprobación del matrimonio gay. 
Y habla de "teofobia" atribuyendo a los homosexuales un componente fóbico similar al que los últimos le otorgan a quienes los discriminan. Observamos que a través de estas apropiaciones se banaliza el uso que le dan los colectivos disidentes al concepto de "homofobia" y se desdibuja su potencial ideológico-político y contestatario al volverlo un término paraguas que lo cubre todo y a la vez nada.

Se hace una operación similar al hablar del derecho a la libertad de expresión y se culpa a las personas LGBTIQ de menoscabarla. Por ejemplo, en "El Papa que huyó por amor (y se fue a vivir con su secretario)" (15/02/2013), Bimbi habla de la renuncia de Ratzinger y del anuncio de que se irá a vivir con su secretario privado; compara la noticia con la de un ex alcalde estadounidense que había abandonado su cargo para convivir con su novio en México y recuerda que el ex papa fue uno de los más acérrimos opositores del matrimonio gay. Allí los comentaristas acusan al periodista de publicar injurias porque dicen que se está burlando de la autoridad eclesiástica al inferir que sostiene un vínculo sexoafectivo con su secretario. Inmediatamente se atacó a los homosexuales de usar la carta "libertad de expresión" para decir lo que quieran pero para evitar que se les hagan críticas en su contra. El ejemplo que sigue ilustra nuestro punto:

[TX1231] Guest a Martin Caballero: cuando hablan ustedes [los homosexuales] es libre expresion, cuando lo hacemos nosotros [los no homosexuales, los cristianos] son insultos. sólo porque [ustedes] son minoria????

Aquí Guest pone de manifiesto que para él/ella los homosexuales califican como insulto todo lo que para los no homosexuales y creyentes califica como libertad de expresión, y que los homosexuales pueden decir lo que quieran y escudarse detrás de ese derecho, acusando al resto de insultarlos. Por ello, los homosexuales por ser una minoría se pueden salir con la suya, y el resto no. Esto se asemeja a lo que observamos que ocurría en el blog BP, donde había un grupo de individuos que se sentían atacados y discriminados por pensar y opinar distinto, por no ser homosexuales y por defender sus valores en un sitio donde se decía que se menoscababan sus principios e ideales. En ambos se acude al topos del abuso a fin de caracterizar el (mal) uso que hacen los homosexuales de la libertad de expresión.

"Libertad" entonces no es sinónimo de decir o hacer lo que se quiera, como se señala en el siguiente comentario: 
[TX609] Mariela Bustamante: Hola a todos, soy catolica, heterosexual. tengo amigos gays, estoy a favor de que no se los castigue por elegir a personas del mismo sexo, pero, seamos considerados, a mi no me gusta ver a dos personas del mismo sexo besandose, porque es algo a lo que no estoy acostumbrada, he leido en unos de los comentarios que dice "miren para otro lado", yo digo "miren para los lados", los gays piden respeto, consideracion, yo les digo, pueden dar un poco de lo que piden??? tengan respeto y consideracion por los que no estamos acostumbrados, aun, a ver dos personas del mismo sexo besandose, tengamos amor al projimo.

Si por libertad se entiende, "hacer lo que se ns canta" estamos perdidos....

Aquí se establece cuál es el límite de lo aceptable: la sociedad no acepta a dos personas del mismo sexo que hagan demostraciones públicas de afecto. Se dice que los homosexuales no respetan a las personas que no quieren verlos besarse, que no son considerados y que no tienen amor al prójimo (de nuevo, topos del abuso). Desde una posición que se anuncia respetuosa, se legitima la desigualación y la minorización de los homosexuales.

Si los homosexuales ${ }^{44}$ fueron violentados tanto en BP y en Tx, en el segundo blog las personas trans y sobre todo las mujeres travestis serían el blanco de ataque y objeto de distintos discursos discriminatorios: en el artículo "Hablemos del subsidio para travestis y transexuales" (27/11/2014) Bimbi argumentó a favor de los proyectos de ley que presentó Rachid en 2012 y que volvió a presentar en 2014 con el fin de otorgar un subsidio de reparación histórica para las personas trans de 40 años o más que residan en la Ciudad Autónoma de Buenos Aires y que perciban un ingreso salarial menor a 3.500 unidades fijas. Bimbi publica este texto después de que se difundiera la noticia a través de distintos medios de comunicación que afirmaba que el subsidio sería de $\$ 8.000 .^{45}$ El autor aclara que la gestión de la Capital Federal había modificado el valor de las unidades fijas pero que el subsidio no comportaría esa suma. Además, dice que las mujeres trans y travestis en su mayoría no tienen acceso a sistemas formales educativos, laborales ni sanitarios; su situación socioeconómica es baja y su esperanza

\footnotetext{
${ }^{44}$ Dicho sea de paso, observamos que en los comentarios de ambos blogs se habla de los homosexuales en masculino, de forma homogénea y como sinónimo de "gays".

${ }^{45}$ Por ejemplo, ver: S/A (26 de noviembre de 2014) "Piden subsidios de $\$ 8.000$ para travestis", Clarín. Disponible en http://www.clarin.com/ciudades/travestis-subidio-rachid-conti_0_r1X8QpvcPQe.html [Consultado el 10 de marzo de 2017]
} 
de vida no supera los 35 años. Por lo tanto, el subsidio se otorgaría a no más de noventa personas.

Este post fue el segundo más comentado de Tx y recibió un total de 842 intervenciones. Allí identificamos que existían dos perspectivas, una en contra del proyecto y otra a favor. En el grupo de quienes se oponían encontramos tres subtipos: A) usuarios que no están a favor del reconocimiento de los derechos de las personas trans y ni a favor de subsidiarlas, B) quienes no están a favor del otorgamiento de subsidios en líneas generales, y C) quienes proponen otras alternativas para paliar la situación que atraviesan las personas trans para que ellas puedan tener los recursos necesarios para mejorar su condición socioeconómica por su cuenta. ${ }^{46}$ Empezaremos por recuperar los comentarios de quienes rechazaban la propuesta de ley de los subsidios para las personas trans, donde colocamos los textos de quienes se oponen al reconocimiento de los derechos de las personas trans y del otorgamiento de un subsidio específico para ellas (subtipo A); estos detentan representaciones estigmatizantes que refuerzan una imagen peyorativas sobre estos sujetos. Recuperamos algunos comentarios:

[TX2351] yanil a Dario: tenes idea la cantidad de gente que vive excluida del sistema??? camina un poco los barrios pobres y te vas a dar cuenta, o crees que la gente cartonea por placer? pero no se disfraza y sale a gatear a la calle, cada unno que se haga cargo de su eleccion y no se victimice... yo obviamente si tengo que tomar un empleado y tengo que elegir entre un travesti o un padre de familia ni lo pienso es un asco que se agarren de su condicion para justificar que les regalen un subsidio no son discapacitados son diferentes porque asi lo quisieron. conozco señores que son gays y guardan las formas y trabajan como cualquiera, despues hacen de su cu... un pito, no anda disfrazado pretendiendo nada. y digo disfrazado porque los travestis tienen esa tendencia, la inmensa mayoria hace notar que es travesti no busca emparejarse a la sociedad.

[TX2405] Rosario a Facundo: Esto es tan absurdo como todo lo que viene pasando. Yo no estoy para nada de acuerdo con esto, así fuese un subsidio de \$100 me parece totalmente erróneo.

Yo estudio en un lugar donde la calle es dominada por ellos, y es desagradable pasar por ahi, es asqueroso ver que son las $9.00 \mathrm{hs}$ am y ellos estan haciendo cualquier tipo de espectaculo en la vereda, sin tener ni siquiera un poquito de

\footnotetext{
${ }^{46}$ Tengamos en cuenta que nuestra clasificación de los comentarios de este post no es taxativa y que los subtipos se pueden superponer entre sí.
} 
prudencia de que hay niños, de que hay colegio cerca y ellos no tienen ningun derecho de ver esto. Por lo tanto que respeto se les puede tener si ellos ni siquiera deben saber que es el respeto. La mayoria de los que trabajan ahi es porque quieren. No me vengan con que la infancia fue dura y por eso trabajan ahi porque no es justificaciòn, mi viejo tuvo una infancia bastante compleja y no por eso es travesti. Y no llego a donde està por subsidios, ni por andar ofreciendo sexo, sino haciendo sacrificio, esfuerzo, poniendo voluntad y aguantarse cualquier cosa para poder darnos una vida mejor. Pero sinceramente esto da VERGÜENZA.

[TX2407] Majito a Rosario: Totalmente de acuerdo con vos también padezco tenerlos frente a mi casa se están drogados, alcoholizados, tienen sexo en calle, desnudos sin respeto a nadie gritando que salgan a laburar como uno.

Estos comentarios ilustran la representación hegemónica sobre las mujeres trans. ${ }^{47}$ Observamos que una vez más se confunde homosexualidad con ser trans; se dice que ser trans o travesti es una elección y que por ese motivo deben hacerse cargo de la vida que eligieron, que no son los únicos sujetos excluidos del sistema y que bien podrían optar por cuidar las formas y emparejarse con (el resto de) la sociedad (topoi de nominación, comparación y realidad). Se prostituyen por decisión propia, "son diferentes porque así lo quisieron", como apunta yanil. Se victimizan, son hombres que se disfrazan y pretenden ser mujeres, son escandalosos, no tienen prudencia ni respeto por nadie, tal como dicen Rosario y Majito respaldando sus dichos con narrativas sobre sus experiencias personales. Gritan, se drogan, toman alcohol, caminan desnudos y tienen sexo en la calle. En estos comentarios se tiende a representar a las travestis como personas que se prostituyen pero que podrían decidir tener (otro) trabajo, "salir a trabajar como uno". Es decir, no se considera a la prostitución como un trabajo ni como una actividad que implique esfuerzos ni sacrificios. Además de discriminarse a las mujeres trans por su identidad y expresión de género, en estos comentarios encontramos un componente clasista que desiguala al colectivo y lo subsume en una condición de marginalidad ante la presunta idea de que existen condiciones y oportunidades iguales para todas las personas, similar al discurso de quienes negaban el derecho al reconocimiento igualitario del matrimonio con el pretexto de que todos, incluso los

\footnotetext{
${ }^{47}$ Nótese que se habla de esta porción de la población trans en un genérico masculino, como por ejemplo "los travestis".
} 
homosexuales, tienen derecho a casarse (salvo que para hacerlo tenían que conformar uniones heterosexuales).

La creencia de un a priori igualitario es la que lleva a sostener que todos están en igualdad de condiciones y gozan de las mismas oportunidades. Más aún, las mujeres trans pueden ser exitosas, tal como demuestran las travestis de la televisión:

[TX2696] lulinka a Romina: de acuerdo total-El ser trans no significa que deban andar por la calle. Sino mirá Flor de La V es un ejemplo de trans laburadora capaz e inteligente. Y con trabajo.Si ella pudo porque los demás no?

[TX3004] sebastian: [...] Y con respectp a que "No tienen laburo, s no es de prostituta" no se donde vivis , preguntale a florencia de la $\mathrm{v}$, o a mucho travestis q los ves a cada rato en la television,, entonces es una joda lo que estan diciendo, yo estuv mucho tiempo sin laburo y nadie me regalo subsidio

Tomando la parte por el todo, se representa a Florencia de la V como el caso paradigmático de éxito de la población trans desde el punto de vista de estos lectores, para quienes la espectacularización de la diferencia y la teatralización de los cuerpos disidentes son prueba suficiente de que una persona trans puede elegir no trabajar en la calle; entonces, quienes se prostituyen lo hacen por decisión propia, no son capaces ni inteligentes. Simultáneamente, en esos textos subyace la representación sobre un trabajador ideal que se esfuerza y se sacrifica para obtener dinero, algo que las personas trans no hacen según los usuarios y lectores de Tx. Esto se reiterará en otros comentarios que asocian al otorgamiento de cualquier tipo de subsidio con un "regalo" para cooptar votos y mantener vagos que quieren la vida fácil porque quieren vivir a expensas del gobierno y de los aportes fiscales de los trabajadores (topoi de utilidad y de economía).

Veamos más ejemplos:

[TX2232] Mariano Agustin Sosa a Alexis Gaido: Coincido. Encima de de haber perdido los valores y todo lo bueno de antes, ahora hay que subsidiar a trolos vestidos de mujer porque unos politicos maricas lo creer correcto. Basta!, para colmo nuestros jubilados BIEN GRACIAS. Idignacion, bronca, violencia, todo eso provoca estas leyes estupidas. Pero tenemos que pensar positivamente, ya llega el 2015 y podremos decir lo que sentimos y pensamos de todas estas cochinadas y porquerias, sumado a la inseguridad y la pobre economia. NUNCA MAS hay que olvidar todo lo que hemos vivido, ya paso en la re 
eleccion de kristina, ahora debemos tener mas memoria activa que nunca para no cometer estos errores y sacar del poder a estos enfermos chantas, ñoquis y atacanes de la familia que son los politicos k. Lo unico preocupante por ahora son los politicos de la oposicion pero ojala puedan aparecer propuestas decentes en 2015 y se pongan serios. ¿Que te paso Argentina? increible el daño que te han echo, antes dabas señales de ser pais de primer mundo (hace muchisimos años atras) ahora pareces la cloaca del mundo. Pobre nuestra Argentina, debemos sacarla adelante pensando en el futuro de nuestros hijos. Basta de destruccion y division entre argentinos, chau kirchnerismo y sus amigos mutantes humanoides.

[TX2574] Analia a Sol Minoldo: Disculpame, es la vida que eligieron! O alguien le puso un revolver en la cabeza y les dijo hacete trans??? Por favor!! Basta de boludeces!!! A ustedes les corre materia marron por el cerebro! No tienen cara en salir a pedir que se debata el tema!! NO LES PARECE QUE HAY COSAS MAS IMPORTANTES EN EL PAIS COMO PARA PREOCUPARNOS POR LOS TRANS?????? Cuantos chicos mueren a diario por la desnutricion??? A mi me importa muchisimo mas que nuestros niños esten bien alimentados, tengan una buena educacion, los hospitales esten equipados como correspondan y tengas un atencion digna cada vez que alguno tiene que asistir a ellos. Yo hace un año que estoy sin trabajo y no pedi ningun plan, ni me hice torta, ni sali a afanar! Me parece que hay que tener un poquito mas de dignidad antes de esperar a que el GOBIERNO LOS MANTENGA! No querian la igualdad??? La tienen, salgan a trabajar, a ganarse el pan como corresponde! Porque hay que darles un subsidio? Por que mueren a causa del sida?? Mmmmmm... Vivimos en un mundo en donde todos sabemos muy bien cuales son los riesgos de no cuidarse en una relacion sexual... Y si no saben como no contagiarse, lean, aprendan, cuidense, pero no por eso tienen que pedir un subsidio... Este tema me da ASCO!

En primer lugar, notamos que Mariano Agustin Sosa nombra a las travestis de modo despectivo como "trolos vestidos de mujer" y a los políticos de la gestión de Cristina Fernández como "políticos maricas". Asimismo, las "leyes estúpidas" que reconocen los derechos de las personas LGBTIQ han conducido a la pérdida de valores que acaban con un pasado que se veía como bueno y que ha sido dañado por el kirchnerismo y sus "amigos mutantes humanoides". Lo monstruoso, lo abyecto, lo menos humano, son las personas LGBTIQ. Apoya su argumentación con la comparación de Argentina con una 
cloaca, comparación quizás poco casual si pensamos en las primeras manifestaciones homofóbicas que el higienismo nacional llevó a asociar con el sexo anal entre homosexuales, como recordaba Bazán. Pero este usuario percibe que hay otros problemas en el país que como éste no son una "boludes" y que son culpa de la ex presidenta y de la comunidad LGBTIQ. Esos problemas serían la destrucción y el ataque de la familia y la división de los argentinos, sumado a la inseguridad y a la crisis económica. Por lo tanto, las personas, trans con su expectativa de recibir el subsidio, conforman una carga para el país. Por último, se expresa la idea de que en las elecciones de 2015 habría un cambio en la gestión política que dará permiso para decir lo que se siente y se piensa de estas "cochinadas y porquerías", hablando otra vez de los disidentes sexo-genéricos y en nombre de un "nosotros" plural cisheteronormativo que tiene una ideología política diferente a la que en ese entonces era la oficial. ¿Y qué es lo que siente este lector? Indignación, bronca y violencia. Como en BP, encontramos que se colocan las figuras de victimarios dentro del colectivo LGBTIQ y las figuras de víctimas por fuera.

En el comentario de Analia se reitera la representación de que ser trans es algo que se elige, al igual que hacerse torta, salir a robar, pedir un plan o salir a trabajar "como corresponde" (es decir, no como trabajadora sexual) ya que están en igualdad de condiciones que todos (de nuevo, un todos no-trans). Ellas tienen SIDA porque no saben o eligen no saber cuidarse, porque es algo que "todos sabemos". Reitera la metáfora fecal para criticar a los defensores del proyecto y repite la idea de que recibir un subsidio no es digno, no es igualitario y que en todo caso constituye una acción de manutención por parte del gobierno. Y sostiene una premisa que se repitió en otros comentarios de que hay otras prioridades, apelando a los topoi de la carga y la economía. Analia destaca con mayúsculas una pregunta para intensificar la fuerza ilocutiva y dice: "NO LES PARECE QUE HAY COSAS MAS IMPORTANTES EN EL PAIS COMO PARA PREOCUPARNOS POR LOS TRANS??????” ([TX2574]). En este sentido, el Estado primero debe ocuparse de otros asuntos que se creen más urgentes y más prioritarios que los que le incumben a la población trans, como los que ella nombra: la desnutrición infantil, la educación y el sistema sanitario. Finaliza el texto diciendo que este tema le da asco. Observamos que la referencia a lo asqueroso, a lo violento, a lo escatológico, a lo sucio y a lo escandaloso se sostendrá en otras intervenciones como esta. Asimismo, vemos que en los dos últimos comentarios se 
apela a una niñez indefensa y a unos jubilados olvidados a fin de sensibilizar sobre asuntos graves y des-sensibilizar sobre aquello que Bimbi quería promover.

Por otro lado, y como anticipamos, el subtipo B del que ahora vamos a hablar es el de quienes rechazan cualquier propuesta de subsidio. En los textos que siguen tenemos a tres usuarios que rechazan los subsidios pero que también condenan a las personas trans (subtipos A y B):

\begin{abstract}
[TX3012] Emanuel Ledesma Out of the Rec: Llendo al grano, las comparaciones son inútiles ya que todos sabemos que los trabajadores promedio, no llegamos a $\$ 8000$. Vamos a los hechos. Estos individuos, los travestis, se encuentran en esta situación por decisión propia. Son promiscuos que quieren sacar provecho de ello. Obvio, sin comerla ni beberla, a base de NUESTROS IMPUESTOS son pagados estos subsidios. Por eso, en mi sano juicio junto a tantos otros trabajadores digo que esto NO ES JUSTO.
\end{abstract}

Emanuel Ledesma Out of the Rec se siente afectado por el otorgamiento de $\$ 8.000$ a las personas trans ya que él dice no alcanzar esa suma de dinero por mes. De hecho, en nombre de todos los trabajadores, intensifica su posicionamiento indicando que "todos sabemos que los trabajadores promedio, no llegamos a $\$ 8000$ ” y que por ello el subsidio no es justo. Los topoi de justicia y de economía le permiten justificar su oposición a este proyecto de ley y a los subsidios en general porque son los impuestos de un "nosotros" que trabaja y, para él, las personas trans no trabajan y no pagan impuestos. Pero este lector también es discriminatorio con "los" travestis ya que, según él, están en "esta situación" (de pobreza, marginación) por su propia decisión. Es decir que son responsables de su condición actual porque eligen ser promiscuos y aprovecharse de los trabajadores (topoi del abuso).

En los siguientes ejemplos se publican imágenes junto con los textos a modo de apoyar la mirada crítica de sus autores. ${ }^{48}$ Veámoslos:

[TX2715] Marcelo a carlos: ¿Está mal no darle trabajo de docente a esta COSA?

¿Qué pensás que es la libertad? ¿Qué pensás que es la justicia? Te lo digo yo que soy recibido en filosofía.

\footnotetext{
${ }^{48}$ Nótese que en todo el corpus de Tx solo hubo cuatro imágenes en total, sin contar los emoticones que también conformaban una módica suma. En cambio, en BP no se usó ninguna imagen.
} 
¿La libertad es que podamos hacer lo que queramos, y no permitir que nadie pueda decirnos nada? ¿Eso es la libertad?

NO!!!!!!!!!!!!! La libertad es poder hacer lo que queramos hacer, aceptando lo que los demás dicen de nosotros. ¿Pensás que si como mierda, o si me doy vuelta la piel para afuera, los demás deberían estar obligados a trabajar al lado mío, a incluírme en sus grupos fingiendo que les gusta? ¿Eso es libertad? ¿Eso es justicia?

Esta falsa justicia que proponen es un retraso para la humanidad, no sean pelotudos. Te hago la última pregunta, y respondela con sinceridad, ¿Pondrías a tus hijos a estudiar con esa COSA que te pasé? Y que no se te olvidé aunque este no es un tema importante, el trasvestismo no es las ganas de ser mujer todo el tiempo, es una perversión, es las ganas de ser mujer solo durante el acto sexual, simplificandoló, QUE TE ROMPAN EL ORTO. ¿Por qué pensás que hay tantos trabas en el bosque? Es una perversión.
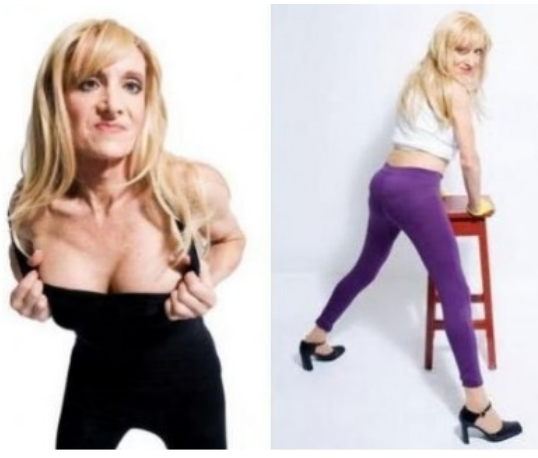

[TX2593] lazaro a Sol Minoldo: Habrá q calzar sunga peluca y salir a cobrar $\$ 8000$ para un buen vivir....... Q vergüenza .....

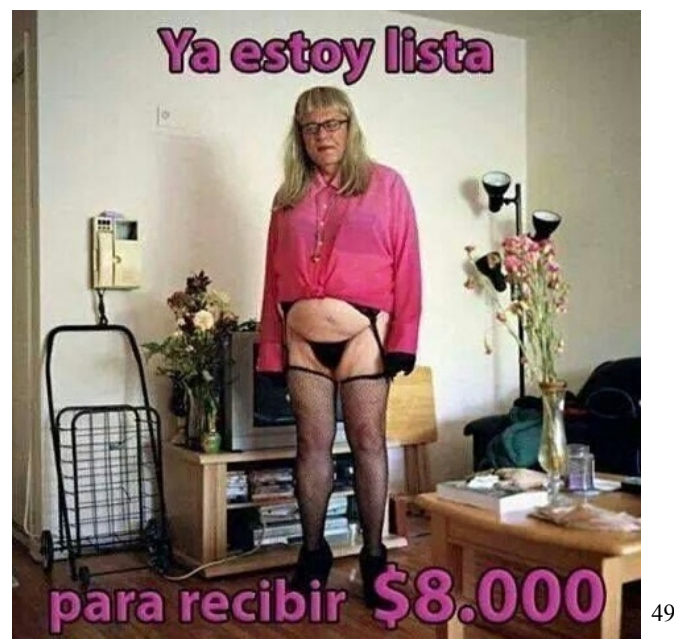

Marcelo, desde su lugar de autoridad como filósofo, nombra a las travestis como una "cosa" comparable a "comer mierda" y que tienen que aceptar que nadie está obligado a

${ }^{49}$ La imagen dice "Ya estoy lista para recibir $\$ 8.000 "$ " 
trabajar con ellas o a incluirlas fingiendo que les parece bien lo que hacen. Ser travesti es una perversión. En sus palabras, "es las ganas de ser mujer solo durante el acto sexual, simplificandoló, QUE TE ROMPAN EL ORTO”, tal como asevera en mayúsculas para enfatizar su punto de vista. Si bien para él este tema no es importante, cree que "esta falsa justicia" es un retraso para la humanidad; nuevamente, el colectivo en cuestión constituye una amenaza para el resto. Por último, desde el bastión de la defensa de la niñez, se rehúsa a permitir que las travestis sean docentes; como pregunta: "Está mal no darle trabajo de docente a esta COSA?". Acompaña la publicación con fotos de la travesti Zulma Lobato. Esta operación se repite en el siguiente comentario, escrito por lazaro, para quien ser travesti es equivalente a "calzar sunga [y] peluca", o mejor dicho, disfrazarse para cobrar los supuestos $\$ 8.000$. Con estas fotos se ridiculiza y caricaturiza a las personas trans de modo peyorativo para desprestigiar sus reivindicaciones $\mathrm{y}$, sobre todo, el proyecto de Rachid. Además, se revictimiza, patologiza y estigmatiza a las travestis y se refuerza su asociación con el mercado sexual.

Hay más comentarios en contra de los subsidios en general (subtipo B), como los que siguen:

[TX2365] Alberto a Dario: Espero no molestar a nadie con lo que voy a decir.

Estoy completamente en contra de los subsidios de ese tipo, en lugar de dar nuestra jubilación les deberían de poner a trabajar en alguna fabrica estatal o similar, dar dinero solo fomenta vagancia o comodidad, yo trabajo de seguridad 12 hs diarias 5 días a la semana incluyendo sábados y domingos ganando 8000 míseros pesos, pago alquiler $\$ 2000$ más $\$ 1000$ de viáticos y tengo 2 hijas y otro en camino, y me las arreglo. PONGAN A TRABAJAR A ESA GENTE Y DEJEN DE TIRAR NUESTRA JUBILACIÓN, NO VAMOS A TENER FONDOS NI PARA LA [jubilación] MÍNIMA A ESTE RITMO DE SUBSIDIOS. TE CASAS SUBSIDIO, TENES HIJOS SUBSIDIO, TE EMBARAZAS SUBSIDIO, ETC. Basta!!!!!!

[TX2431] yanina a Alicia: No la quiero atacar,pasa que da mucha bronca ver tantos subcidios,y tantos descuentos, porque ya el sueldo no nos alcanza para nada y ver que ahora nos descuentan mas plata para esto?

Aquí observamos que los usuarios rechazan el otorgamiento de cualquier tipo de subsidios por tres motivos: se dice que el salario de "nosotros" los trabajadores no es 
suficiente, que habrá más descuentos para ello y que fomentan vagancia y comodidad (topoi de carga y de economía). Subyace la idea de que el dinero del fondo jubilatorio se acabaría si se sigue con el ritmo de dar ayudas sociales. Alberto además propone otras soluciones para mejorar la calidad de vida de las personas trans y de los beneficiarios de los subsidios: dar trabajo. Por ello, su texto lo colocamos entre los subtipos B y C, de quienes se oponen al proyecto porque se cree que no presentan una solución viable para nadie.

Por otro lado, en el subtipo C identificamos comentarios que si bien rechazan el proyecto de ley, defienden los derechos de las personas trans y sugieren alternativas para paliar sus problemas. A continuación reproducimos algunos de ellos:

[TX2427] sofia a lucia: Estoy de acuerdo en que se necesita una cambio social, mayor libertad sexual, para que ninguna condición sexual condicione la vida de nadie. No es justo que haya menos oportunidades, solo por una cuestión de orientación sexual, genero, etc. Pero sinceramente, con darles un subsidio no se arregla nada, no hay ninguna batalla ganada en eso. Lo único que veo, es solo mi opinión, es que así consiguen una manera fácil y poco comprometida de afrontar el problema: [los funcionarios del Estado] no invierten en apoyo psicológico, ni se plantean un cambio desde la educación de todos, ni promueven leyes que les den una igualdad real. Personalmente, me parece casi un insulto en la cara de la gente que realmente se ha visto afectada por esta situación de desigualdad.

[TX2461] lucia a cami: Estoy de acuerdo.Yo creo que la solución no está en dar subsidios, de hecho creo que la solución está en incluir dando trabajo. Lamentablemente veo comentarios diciendo que las trans no merecen nada, de hecho se las tildó de vagas por este proyecto. Yo creo que las trans no quieren un subsidio, quieren laburar. Pero veo que la gente es muy cabeza cerrada. Por los comentarios despectivos te das cuenta que la sociedad no está lo suficientemente evolucionada para incluir. Por eso es que se toman estas medidas que son soluciones rápidas y superficiales a una problemática mucho mas profunda. Igualmente noes justo que sr insulten a las trans por este proyecto, ni que se las compare con los jubilados. Es una guerra que no tiene mucho sentido.

Para estas usuarias existe una situación de desigualdad que no puede resolverse con el otorgamiento de subsidios. El topos humanitarista las lleva a proponer soluciones 
inclusivas que tiendan a generar un cambio sociocultural, ya sea a través de la educación o de la incorporación al mercado laboral formal. Para ellas los subsidios son soluciones rápidas y superficiales; son insulto en la cara de las posibles beneficiarias que quieren trabajar y que no son vagas como decía la gente que era "muy cabeza cerrada". Si bien algunos comentarios de este subtipo ponen en circulación sentidos contrahegemónicos de la diversidad sexo-genérica, encontramos otros que sugieren propuestas diferentes y que a la vez critican a las personas trans y a todo tipo de subsidios (subtipos A, B y C); veamos un ejemplo:

[TX2988] juan carlos taboada: Todo lo que decís esta muy lindo pero solo defiende tu postura yo no tengo nada contra los travestis homos o les[bianas] pero me gustaría que como cualquier persona en el mundo se hiciera cargo de si situación hay millones de personas que son maltratadas día a día por cualquier cosa y no cobran subsidio millones que se mueren de hambre día a día gente que no le alcanza la guita para comer criar a sus hijos y no cobra subsidio, vos pretendes hacernos creer que son 60/70 travestis que lo van a cobrar EN CONCEPTO DE QUE !!! REPARACIÓN HISTORICA !!! La verdad que es una vergüenza que esto sucede los travestis no aportan nada a la sociedad elijen un estilo de vida y después no se hacen cargo, no me parece bien que sean mal tratados pero opino que mas que subsidio deberían hacer que estudien que se preparen años algo útil a la sociedad, con tu criterio mañana le tenemos que dar subsidio a los chorros por trabajar de algo insalubre, a los drogadictos por drogarsey no ser entendidos, a los.violadores por ser incomprendidos y así sigue la lista de personas que solo se miran el ombligo de si misma NO CREO EN EL PROYECTO Y ME PARESE UNA LOCURA Y UNA FALTA DE RESPETO A LOS QUE LABURAMOS DIA A DIA Y AGUANTAMOS A POLITICOS CHARLATANES Y OPORTUNISTAS

Nuevamente aparece la discusión por las prioridades que son más urgentes que aquellas que afectan a las travestis, como las "millones de personas que son maltratadas día a día por cualquier cosa", quienes mueren de hambre o a quienes no les alcanza la plata (topos de economía). Las travestis así son vistas como ciudadanas de segunda que no aportan nada a la sociedad y que podrían estudiar y trabajar bajo un supuesto de que están en las mismas condiciones que cualquier ciudadano y eligen tener el estilo de vida que tienen sin hacerse responsables de ello. No obstante, aquí el usuario se opone a los malos tratos contra las personas trans, si bien las sitúa en el mismo plano que a los 
drogadictos, a los violadores y a los ladrones (topos de comparación). Propone no dar subsidios sino que se las haga estudiar y trabajar. Por lo tanto, el proyecto es una falta de respeto y una locura, combinándose los topoi de desventaja y de abuso.

Para sintetizar los juicios que aparecen en los textos analizados, las personas LGBTIQ son seres promiscuos, enfermos y tienen HIV/SIDA. Son intolerantes, violentos y ateos y por ello discriminan y ofenden a los heterosexuales y a los católicos. A través de su influencia en la política, los homosexuales promueven la legalización del aborto, el fin de la familia y del matrimonio. Algunos hacen alboroto de su elección y de sus gustos y creen que pueden tener más derechos que los heterosexuales por su propia condición. En paralelo, se afirma que las personas trans eligen serlo dado que subyace la creencia de que son hombres homosexuales que se disfrazan de mujeres para saciar una perversión sexual y que, por lo tanto, podrían buscar ayuda psicológica y curarse. De igual modo, si se dedican a la prostitución es porque les gusta, porque se autoexcluyen, se autodiscriminan y son vagos porque bien podrían estudiar y buscar trabajo en cualquier empresa ya que tienen las mismas oportunidades que cualquiera. En consecuencia, no deberían esperar resarcimientos por parte del Estado porque en el país hay otras prioridades y necesidades más urgentes, como la desnutrición infantil, la pobreza, la educación, la inseguridad o la crisis económica que afecta en los ingresos de los jubilados, médicos, docentes y el resto de los trabajadores. Por esto, cualquier propuesta de ley para subsidiar a las personas trans es injusta porque promueve la vagancia y le saca plata a los trabajadores, no resuelven los problemas socioeconómicos de fondo y en todo caso son formas de captar votos a favor del partido político de Cristina Fernández. Aquí se emplearon los topoi de peligro, legalidad, desventaja y comparación, pero sobre todo los de economía, abuso y carga: según los usuarios, si la situación económica y sociopolítica del país es tan mala, hay que ocuparse de eso primero en vez de regalarle plata a las travestis o crear leyes que benefician a unos pocos.

\subsubsection{Conclusiones provisorias}

Al igual que a lo largo de la historia de la homobilesbotransfobia, los comentarios de los blogs condensan los atributos de enfermedad, delincuencia y abyección en los rostros, en los cuerpos y en el imaginario sobre las personas LGBTIQ. 
Tanto en BP como en $\mathrm{Tx}$, los comentarios con representaciones discursivas discriminatorias sobre las personas LGBTIQ coinciden en presentarlas como sujetos enfermos, desviados, promiscuos, perversos y discriminatorios. En BP identificamos un particular énfasis sobre la acusación de "heterofóbicos" a quienes se situasen dentro del espectro LGBTIQ y que criticasen a sus interlocutores por sus opiniones. Más aún, se apeló a la existencia de un credo o lobby gay que opera en los ámbitos científicos y políticos a fin de torcer el brazo de los gobernadores para aprobar leyes que les otorgaran privilegios o un trato preferente, como el matrimonio gay y el aborto. En cambio, en Tx la caracterización heterofóbica no fue tan común como aquella que colocaba a homosexuales y a travestis en el lugar de intolerantes y discriminadores hacia todos los que piensen distinto a ellos, sobre todo a las personas religiosas; así, se construye la imagen negativa de las personas LGBTIQ como enemigos del pueblo e incluso como "enemigos de Dios". En ambos espacios, los comentarios dan cuenta de sentimientos de repugnancia, indignación y asco, que como observa Carlos Figari (2009) son emociones que regulan e instituyen las diferencias materiales y simbólicas de la sociedad contemporánea y que fijan sentidos dominantes y subalternizantes sobre este sector.

En los dos blogs vemos que se construye un "otro" violento, un interlocutor discursivo al que se lo representa negativamente. A la vez, se nombra en términos positivos a quienes forman parte de un "nosotros", ya sea este un grupo de referencia o de pertenencia. En los dos blogs se sostuvo, no sin resistencias, que los homosexuales y las personas trans conducirían al fin de la familia, del matrimonio y de la humanidad. En ambos encontramos que predominó el uso de los topoi de peligro, de abuso, de carga y de economía. Con menos frecuencia, se emplearon los topoi de nominación, de desventaja, de historia, de realidad, de legalidad, de desventaja y de comparación (analogía y diferencia). Allí las personas LGBTIQ ocupan el lugar de victimarias dado que cometen actos moralmente censurables y se los imponen al resto; más aún, tienen la intención de generar daño a unas víctimas "otras". Los últimos conforman un grupo difuso vulnerado, una nueva minoría mayoritaria de personas que no son atendidas por un Estado nacional que regala subsidios, mantiene vagos y se ocupa de las necesidades de unos pocos y no de las prioridades más urgentes, tal como se lee en los relatos en los que se defiende a las familias heterosexuales, a los niños desnutridos, a los ancianos con una jubilación baja, a los discapacitados, a los familiares de las víctimas de la 
inseguridad, a los docentes y médicos mal pagos y a los trabajadores con salarios insuficientes.

Para los usuarios que encarnan las cruzadas anti-queer, el Estado legisla para unos pocos y promueve leyes para cubrir las necesidades de un grupo acotado mientras en el país hay necesidades y problemas vinculados con la educación pública, la salud pública, la economía y la desnutrición infantil. Las víctimas no-gays y las víctimas notrans se sienten afectadas por leyes que (esta vez) no atienden sus necesidades y porque creen que sus derechos se ven menoscabados. En consecuencia, en ambos sitios hay una tendencia a responsabilizar y culpabilizar a las personas LGBTIQ por una gama amplia de cuestiones: por impulsar leyes tendientes al retraso de la humanidad y a la destrucción de la familia y de la sociedad normal a través de su participación en la política; por imponer sus ideales y promover la discriminación religiosa y leyes injustas e desigualitarias en detrimento de los derechos del resto; por esperar que todos acepten sus locuras y perversiones y por no querer curarse; por poner por delante su egoísmo personal y sus deseos de formar familia ante los derechos de los niños; por ser vagos y esperar recibir plata del Estado y por querer beneficiarse de los impuestos de quienes trabajan en un contexto de malestar económico; por no educarse y no trabajar; por optar por dedicarse a la prostitución y no a trabajar (en otro rubro); y por no cuidar sus formas y aun así esperar que la sociedad los respete.

De este modo, se construye una imagen de un sujeto queer monstruoso y asqueroso, perverso y enfermo, multiforme pero uniforme a la vez, que atenta contra la libertad, la igualdad y la justicia, a la vez que reclama estos tres principios para sí. Sin más, se trata de un chivo expiatorio queer, una bruja creada para cazarla, construida y perseguida por discursos plurales que acuden a la violencia para proteger las fronteras de lo que sus portavoces consideran como "normal" y preservar (o recuperar) un orden que se dice que está bajo amenaza. En consecuencia, cuando en los blogs una persona LGBTIQ (o que se percibe como tal) manifiesta emociones o posturas "problemáticas" para el status quo neoliberal católico-cisheteropatriarcal, y cuando se aleja de los marcos de aceptabilidad y tolerancia social, vemos que se la representa como una victimaria y un peligro que se debe contener y/o eliminar. Hay comentarios que operan en sintonía con esto ya que buscan obturar el ejercicio del derecho a la libertad de expresión de las personas LGBTIQ de diferentes maneras: las atacan verbalmente, ${ }^{50}$

\footnotetext{
${ }^{50} \mathrm{Al}$ respecto, Verónica Dema afirma que para ella hay usuarios que dejaron de intervenir en el espacio a causa de los comentarios violentos que recibieron; volveremos sobre este tema más adelante.
} 
detentan representaciones prejuiciosas sobre ellas, califican y denuncian sus dichos como discriminatorios y violentos, piden la eliminación de sus comentarios para silenciar las voces disidentes, y demandan la defensa de la propia libertad de expresión y libertad de culto - a pesar de profesarse ideas y valores que promueven la intolerancia contra las personas LGBTIQ. ${ }^{51}$

Sumado a ello, podemos identificar que allí se ejerce una inversión de la retórica de la inversión: los "invertidos" de antes son desplazados de su lugar de alteridad y ese lugar de sujetos-objetos de violencia pasan a ocuparlo todos los no-homosexuales y notrans que ven sus derechos afectados ante el reconocimiento formal de los derechos de las personas LGBTIQ y al no sentirse abarcadas por las leyes que se ocupan de este sector. Dicho de otro modo, las personas cisheterosexuales temen por la pérdida de los derechos que han gozado por siglos ante la percepción de que hay normas que son un beneficio y un privilegio (no un derecho) de unos pocos. Así, las mayorías devienen en minoría al mostrarse como los nuevos excluidos y los nuevos marginales; objetan que se las discrimina, se las ataca y se las censura por tener un pensamiento distinto al que profesan los sujetos queer y acuñan el concepto "heterofobia" como matriz de justificación de su condición de desigualdad. Pero estas apropiaciones y resignificaciones de las palabras que original e históricamente constituían las banderas de las luchas políticas de los movimientos de disidencia sexo-genérica en el país no hacen más que subvertir, devaluar y despolitizar su sentido contestatario y resignificarlo en contra de sus primeros defensores. De esta manera, la totalización de la diferencia y de la desigualdad lleva a ocultar la trama de relaciones desigualitarias que excluyen a las personas LGBTIQ y a otros sujetos subalternizados. En paralelo, se obtura la comprensión sobre las responsabilidades colectivas e individuales en el sostenimiento o en el cuestionamiento de las mismas y se deslegitiman los pedidos de reconocimiento, reparación y justicia de las personas LGBTIQ al tergiversar sus opiniones, sus experiencias e identidades y al generar miedo y desconfianza hacia este sector. Y de la mano de la presunción de que todas las personas están en igualdad de condiciones, se denomina como "privilegio" a los derechos consagrados o reclamados por este colectivo

\footnotetext{
${ }^{51}$ Esto nos lleva a pensar en el proyecto de ley de libertad religiosa (religiosa (Expediente 10-PE-2017) que el Poder Ejecutivo impulsó en junio 2017. Allí se intenta legalizar y legitimar la figura de la objeción de conciencia y penalizar los actos discriminatorios y los crímenes motivados por el credo de las víctimas. Inmediatamente, distintas organizaciones LGBTIQ manifestaron su repudio y expresaron su preocupación ante la posibilidad de que se restrinjan las libertades de las personas LGBTIQ en nombre de la libertad religiosa; por ejemplo, ver: PAULÓN, E. (17 de julio de 2017) "Restringir derechos en nombre de la libertad", InfoBae.
} 
porque son "desigualitarios", mientras que se oculta la trama de poder que históricamente ha privilegiado a quienes formaban parte del grupo cisheterosexual.

Por otra parte, observamos que en ambos blogs permanentemente se renegocian los sentidos de lo aceptable y lo justo en relación con las sexualidades y los géneros normativos y no normativos. Las personas LGBTIQ son colocadas en un lugar de subalternidad incluso en espacios donde se abordan sus problemáticas ya que los usuarios que allí participan expresan sus ideales y valores en detrimento del derecho a una vida libre de discriminación de las personas LGBTIQ; anteponen su derecho a la libertad de culto en paralelo con su derecho a la libertad de expresión en vistas a la sujeción de este colectivo a un orden material y simbólico cisheteronormativo que excluye sus identidades, corporalidades y prácticas deseantes y que a la vez incluye algunas de ellas en ciertas condiciones de aceptabilidad social más o menos explícitas y más o menos limitadas y con reservas. Por lo tanto, los hombres gays pueden amarse pero no expresar públicamente su afecto; pueden acceder a una unión civil pero no al matrimonio - a menos que se casen con una mujer, porque se considera que el matrimonio es una institución religiosa que no acepta a los homosexuales. Las travestis serán aceptadas en la medida de que sean parte de la cultura del entretenimiento mediático, como Florencia de la V, y no como trabajadoras sexuales o prostitutas; tampoco se les dará trabajo porque son personas enfermas, escandalosas, exhibicionistas y vagas que esperan que se las mantenga.

Observamos que la limitada asimilación e incorporación de las mujeres trans y de los hombres y mujeres homosexuales en la sociedad y en el reino de los derechos humanos están sujetas a criterios de docilidad y de sumisión que buscan contener y disciplinar sus prácticas y, en especial, sus prácticas discursivas: si un comentarista se identifica o se muestra próximo a algo que se identifique como parte del colectivo LGBTIQ, será atacado en cuanto se exprese en contra de la religión, Dios, el Papa y la Biblia, o en cuanto se exprese a favor del matrimonio entre personas del mismo sexo, la adopción y el subsidio para las personas trans. Y ese usuario será objeto de más críticas si su texto contiene elementos percibidos como violentos, sea por el uso de mayúsculas, de signos de exclamación, de agresiones verbales, de insultos, de todos estos elementos o ninguno de ellos. Así, vemos que los ataques dirigidos a lo que sea percibido como algo vinculado a lo queer son manifestaciones homobilesbotransfóbicas que apuntan a vigilar, contener, disciplinar y castigar la disidencia en tanto se muestre demasiado disidente y desobediente; esto es, en la medida de que se escape de los marcos de 
inteligibilidad y admisibilidad trazados (no sin resistencias) entre los usuarios de los blogs.

En síntesis, vemos que "igualdad”, “justicia", "derechos humanos" y "democracia" son palabras vaciadas del significado político que le dieron los movimientos LGBTIQ. Los comentaristas que encarnan las cruzadas anti-queer se las reapropiaron en pos de la denegación de los derechos de este sector. La despolitización de las banderas LGBTIQ y su consecuente re-politización en manos de comentaristas adversos a los derechos de este grupo minorizado parecen configurar y materializar discursos ideológicos teopolíticos, difusos y contingentes, pero a la vez contundentes y para nada ambiguos: configuran un "nosotros" colectivo que se enfrenta con un "otro" queer que genera miedo y repulsión, y al que hay que frenar para que deje de avanzar sobre lo que pertenece a los cisheterosexuales. Reconocemos que los últimos se sienten vulnerados y que participan en estos espacios como forma de expresar su opinión y de ejercer su ciudadanía pero también de reclamar por la protección de sus derechos. Por ejemplo, quienes sienten que la institución del matrimonio verdaderamente estará en jaque si se pueden casar dos hombres o dos mujeres cuestionarán no solo a quienes se puedan casar sino también a quienes hayan sido responsables de otorgar esa posibilidad.

Los comentarios aquí recopilados construyen una imagen de un demonio popular queer, que recae particularmente sobre hombres homosexuales y travestis y mujeres trans. Esto no es un hecho reciente: los estudios sobre la historia de la homosexualidad y, por lo tanto, de la homofobia, nos muestran que en Occidente y específicamente en Argentina se suscitaron pánicos homosexuales en respuesta al temor de ser "contagiado" por la homosexualidad de otro o de ser confundido con un homosexual; por esto, por ejemplo, los hombres heterosexuales que se sienten amenazados ante la cercanía de homosexual reaccionan con violencia homófoba (Sedgwick, 1998, 2002). ${ }^{52}$ Retomando a Salessi (1995), los pánicos homosexuales nos habilitan a comprender los procesos históricos de construcción de la diferencia en el país. Dice que en Argentina se creó esta ansiedad cultural, se la exageró, promovió y utilizó para controlar y estigmatizar a las poblaciones que la cultura patriarcal y burguesa hegemónica consideraba peligrosas. Las nociones de una presunta confusión genérica y corrupción sexual contribuyeron a la diseminación de una homofobia que se

\footnotetext{
52 Hoy en día algunos victimarios utilizan el concepto de "pánico homosexual" como argumento de defensa para justificar su violencia homofóbica en casos judiciales en donde se los condena por dañar la integridad de una persona presuntamente homosexual.
} 
exacerbó con la publicidad que recibieron algunos de los eventos catalogados como “escandalosos" en la prensa nacional, después de los que se empezó a punir legalmente la homosexualidad. Estos hechos no estaban aislados sino que se sumaron los estereotipos negativos que difundían los textos científicos, eclesiásticos y literarios. En este sentido, el pánico homosexual y sus usos políticos e ideológicos sirvieron para perseguir a homosexuales pero también para regular los lazos de la sociedad en su totalidad. De este modo, se consolidaron modelos de una masculinidad viril, de una feminidad dócil y de la heterosexualidad como la única orientación sexoafectiva posible, como también se delimitaron qué conductas y modos de vinculación entre personas del mismo sexo eran socialmente aceptables.

Pero estos miedos no se generan solo en torno a la homosexualidad masculina ni se reducen a meras sensaciones pasajeras de un grupo o de un individuo. Se trata de un proceso más amplio en el que hay grupos que dicen que se sienten amenazadas y que temen por la pérdida de sus valores y la destrucción de los lazos societales que son nucleares para una sociedad en un contexto particular. Por eso parece pertinente acudir a un concepto más amplio, el de pánicos morales. Según Kenneth Thompson (2014), los pánicos morales deben pensarse en relación con sistemas de regulación y de representación social, ya que son sintomáticos de conflictos y tensiones sociales más amplias en las normas culturales y morales. Se trata de pánicos que se presentan como una amenaza al modo de vida hegemónico en tanto se dice que son potencialmente inmorales. Ejemplos de ello son los pánicos sobre los crímenes, sobre los jóvenes o sobre las personas consideradas sexualmente promiscuas.

El sociólogo Stanley Cohen explica que:

Las sociedades padecen, cada tanto, períodos de pánico moral, cuando determinada condición, episodio o persona o grupo, se vuelve una amenaza a los valores e intereses de una sociedad. En los medios masivos de comunicación, la amenaza siempre es presentada con determinada estética que se propone como estereotipo. Las trincheras morales son manipuladas por editores, obispos, políticos y otros ideólogos de la derecha; los expertos acreditados socialmente pronuncian sus diagnósticos y soluciones; se desarrollan o (más a menudo) se echa mano a distintos modos de lidiar con el tema. Entonces la condición desaparece, se diluye o se deteriora volviéndose menos visible. En ocasiones el tema del pánico es relativamente novedoso, pero otras veces es algo que ya existía desde tiempo antes y se torna visible 
súbitamente. A veces el pánico llega y pasa, excepto en el folklore y la memoria colectiva, y otras veces tiene repercusiones más serias y duraderas que podrían producir cambios en las políticas sociales, en las leyes o incluso en el modo en que una sociedad se piensa a sí misma (citado en Thompson, 2014: 23)

Los pánicos morales se vinculan con la desestabilización de los valores fundamentales de una sociedad, cuyos autores son los "demonios populares" y cuya resolución se equipara con exigencias de mayor control o regulación. Pero también se relacionan con la disputa de valores y estilos de vida por parte de distintos sectores en pugna en un contexto de cambios sociales acelerados, de aumento de la diversidad social y de nuevos parámetros de producción y distribución de la riqueza.

Thompson detecta que las cruzadas morales multiplican el descontento hacia algunas clases o grupos sociales a la vez que marcan los límites de lo aceptable. Los pánicos morales generan un alto nivel de preocupación y un aumento del nivel de hostilidad hacia los causantes de tal malestar. Los pánicos morales sobre la sexualidad en la sociedad contemporánea representan fuerzas de poder que intentan regular la sexualidad y los cuerpos. La proliferación de discursos sobre la sexualidad en los medios de comunicación hizo surgir espirales de significación que desembocaron en pánicos morales ante la amenaza de la erosión de ciertos valores a causa de conductas consideradas social y sexualmente desviadas, tales como la pornografía, los abusadores, la violencia en la televisión, y la homosexualidad. ${ }^{53}$ Indica que después de la despenalización de la homosexualidad en Inglaterra, el argumento criminal o de desviación sexual ya no podía utilizarse para denunciar prácticas que se pensara que eran inmorales. Por lo tanto, con cada vez más frecuencia se acudió a realizar denuncias indirectas que agitaban temores con respecto a supuestos aumentos de casos de pedofilia o que alertaban sobre los riesgos que podría tener sobre los niños que se modificaran las ideas con respecto a los géneros y a las sexualidades, los roles de los hombres y las mujeres, los modelos tradicionales de familia y el cuidado de los hijos, similar a lo que leímos aquí en los comentarios que citamos.

\footnotetext{
53 Como observa Jeffery P. Dennis (2015), desde la sociología y la antropología se perpetúan representaciones intolerantes, estigmatizantes y dañinas sobre las diversidades sexo-genéricas al reforzar la idea de que los homosexuales son seres desviados, incluso en aquellos contextos donde se despatologizó y se descriminalizó esta orientación sexual. Por ejemplo, desde la teoría de la desviación y del etiquetado, autores como Howard Becker (2009 [1963]) no han hecho más que referirse a la homosexualidad en múltiples ocasiones como ejemplo paradigmático de las conductas desviadas, a veces ignorando las experiencias y percepciones de estos sujetos.
} 
Con respecto a la crisis del SIDA, por ejemplo, ve que en Inglaterra y en Estados Unidos las representaciones mediáticas y los procesos de construcción discursiva apuntaron a difundir una sensación de riesgo y a diseminar posibles pánicos morales con respecto a la sexualidad. Ideas sobre qué es lo "normal", lo "natural" y, por lo tanto, lo "moral" sirvieron para regular algunos discursos y legitimar una ideología en defensa de la familia tradicional y en rechazo de la diversidad social y sexual. Afirma que el SIDA recibió un tratamiento estigmatizante y moralizante, que marcó como parias y como desviados sociales a quienes lo padecían. Denominaciones como "peste gay" también contribuyeron a promover ansiedades en contra de los homosexuales. El autor ve que la confrontación entre los parámetros de respetabilidad y los valores de permisividad sexual llevaron a adoptar posiciones absolutistas y a separar a los ciudadanos "normales" y respetuosos de aquellos que los amenazaban; esto es, aquellos sujetos catalogados como peligrosos, locos, desviados, extranjeros, criminales o perversos. Los medios sensacionalistas promovieron ansiedades y publicaron historias asociadas al SIDA que eran cada vez más escandalosas, produciendo una atmósfera de pánico. No solo recordaron quiénes eran los demonios populares sino que también presentaron al SIDA como una enfermedad moral de una gravedad comparable a la de la peste negra y el Holocausto. Dijeron que tendría consecuencias perjudiciales para la vida "normal", como la destrucción de la familia y de la salud de las personas. Observa que los promotores de este pánico moral apelaron a la ira de Dios que surgía en reacción a las prácticas "ilícitas" o "inaceptables" que realizaron los sujetos con SIDA, que se decía que eran adictos a la droga, prostitutas, homosexuales y bisexuales: a todos ellos se los culpabilizaba de haber contraído la enfermedad y de exponer al resto.

En Argentina, las ansiedades con respecto a las sexualidades e identidades de género disidentes son suscitadas de manera circular a lo largo de la historia. Las justificaciones que se le dieron a las pestes y males que azotaron a las ciudades argentinas se vincularon con un pecado nefando, la sodomía. Los descubrimientos de fotos de cadetes militares en los '40 en Buenos Aires y su posterior exposición mediática también condujeron a un aumento de la ansiedad provocada por la manifiesta amenaza homosexual como luego sucedió con el surgimiento de la "peste gay". ${ }^{54}$

\footnotetext{
${ }^{54}$ Más recientemente, hubo otro caso pánico moral ligado a las sexualidades no normativas en relación con el evento "Miércoles de placer" que organizó el Área de Comunicación, Géneros y Sexualidades de la Facultad de Ciencias Sociales de la Universidad de Buenos Aires. El 1 de julio de 2015 los medios de comunicación estallaron con la denuncia de que había personas teniendo sexo en público en la facultad. Por varios días difundieron videos descontextualizados de estas performances y trasmitieron testimonios
} 
Observamos que los juicios morales de ese entonces guardan similitud con los que hallamos en los comentarios en los que se debatía en torno a la posibilidad de otorgar un subsidio a las personas trans y al reconocimiento igualitario del matrimonio y la adopción. ${ }^{55}$ Vemos que hay un continuum de ansiedades que por ocasiones está latente y por otras manifiesta y que gira en torno a la conservación del status quo y de la preservación de valores asociados al modelo hegemónico de familia heterosexual que se apoyan sobre discursos medicalistas y religiosos y discursos proteccionistas sobre los derechos de la infancia. A la vez, buscan conservar las fronteras binarias que separan lo masculino de lo femenino, al hombre de la mujer, al heterosexual del homosexual y al cisgénero de la persona trans.

En consecuencia, los pánicos morales refuerzan los procesos que excluyen a las personas LGBTIQ al suscitar temores populares y al representarlas como figuras demoníacas que ocupan un rol activo en la tarea de destruir lo que se siente como propio de la sociedad "normal". En este sentido, los intercambios en los blogs resucitan esos miedos y ansiedades y construyen demonios populares queer que vulneran el modo de vida hegemónico desde su lugar de otredad inmoral, enferma y perversa. La violencia en su contra es un mecanismo para preservar un orden que se siente en riesgo y, paralelamente, la identificación de un "otro" amenazante legitima el pedido de que se tomen medidas para defender la propia mismidad. Dicho en otras palabras, las intervenciones escritas violentas contra las personas LGBTIQ son modos de intentar proteger y conservar el orden existente. Expresan juicios peyorativos sobre los presuntos culpables para demandar su marginación y justificar su discriminación.

de estudiantes que estaban horrorizados ante lo sucedido, omitiendo los detalles detrás de la organización del evento y los justificativos teóricos del mismo. Además, demonizaron a sus responsables a la vez que obturaron la comprensión sobre las prácticas sexuales divergentes que incluían sadomasoquismo, leather, bondage, uso de juguetes sexuales y otros tipos de prácticas eróticas no genitales que estaban relacionadas con el movimiento posporno. Así, se delimitó qué prácticas eran admisibles y cuáles eran desviadas mientras se criticó al feminismo y a todo tipo de sexualidad no normativa. En pocas palabras, al decir del Dr. Mario Pecheny, se trató de una verdadera "caza de brujas" promoviendo lo que en la sociología se cataloga como "pánico moral". Ver: PECHENY, M. (2015) "Dinosaurios vivos", Página/12, Suplemento Soy, 10 de julio de 2015. Disponible en http://www.pagina12.com.ar/diario/suplementos/soy/1-4076-2015-07-11.html [Consultado el 23 de enero de 2016]

55 Al respecto, Bruno Bimbi (2010) nota que los argumentos que se expusieron en el Senado en los debates sobre la Ley de Matrimonio Igualitario rechazan la unión matrimonial por parte de personas del mismo sexo y su posibilidad de adoptar, en consonancia con una ideología imperante que busca resguardar las instituciones de la familia y del matrimonio para las parejas heterosexuales y cuidarla de aquellos que las llevarían a su fin, como se decía en ese entonces. Por otra parte, notamos que hubo menos disidencia en los debates parlamentarios sobre la Ley de Identidad de Género, donde primó una mirada enfocada en los derechos humanos, en el derecho a la identidad y al reconocimiento, y al deber del Estado de resarcir a un grupo minoritario que fue históricamente vulnerado (Farji Neer, 2014). 


\section{3. "Mudate a este milenio, marica reprimida": discursos resistentes}

En este apartado examinamos los discursos que resisten a las representaciones que identificamos en la sección anterior. Estas prácticas de contestación ponen en circulación sentidos contrahegemónicos y alternativos sobre las personas LGBTIQ. En ellas se valúa positivamente a este colectivo, a las leyes que reconocen sus derechos, a los posteos de los blogs, a sus autores y a los blogs. Al mismo tiempo, observamos que hay comentaristas que se distancian discursivamente de los perpetradores de las cruzadas anti-queer. Más aún, los valúan negativamente e incluso los agreden, algo que ocurría con más frecuencia en BP que en Tx en el período analizado.

\subsubsection{Boquitas pintadas}

En este blog se expresan sentidos afirmativos de la diversidad sexo-genérica, como se ve en los comentarios que extrajimos del post " ¿Todos y todas somos bisexuales?" (13/01/2014). En el artículo, el psicólogo Alejandro Viedma escribe sobre las experiencias de sus pacientes, sus orientaciones sexuales y sus etiquetas y categorizaciones. Dos comentaristas dicen:

[BP1297] principe de viana reino navarr: Es fantástico tu blog, te felicito por la labor que desempeñas. Lo encontré siguiendo a Jonatan, el director del corto 'Puertas Adentro' y el tema del que hablas me da de lleno. Mi historia sería propia de un licenciado en psicología como el doctor Viedma, soy consciente de mi homosexualidad desde los 6 años, la represión familiar y del entorno me afectó pero siempre supe definirme a mi mismo y quererme. El 'problema' fue cuando empecé a intimar con otros gays, me atraían físicamente pero me constaba conectar intelectualmente, lo achaqué a mi represión pero al final te das cuenta de que tanto la sexualidad como el enamoramiento dependen mucho del caracter y la afinidad con otras personas. Yo me defino como 'extraterrestre', amo la forma de ser, de mantener un relación, de querer incondicionalmente de las mujeres y deseo la fuerza y el físico de los hombres y para mi si es un problema de dificil solución, encontrar un hombre que ame 
como una mujer pero que se comporte sexualmente como un hombre, ¿bisexual, gay reprimido?, no, extraterrestre me gusta más.

[BP1322] alberto leonelli: Felicitaciones Alejandro y Boquitas nuevamente! Las etiquetas/rótulos no deberían prevalecer sobre las verdaderas aspiraciones de una persona...pero esto todavía sucede...es un largo y arduo camino.

Y recordando al cantautor uruguayo Daniel Viglietti y su tema 'a desalambrar', que bueno seria que pudiéramos empezar 'a desetiquetar/nos'...

saludos

Alberto Leonelli

Aquí los usuarios comparten experiencias personales, cuestionan el uso de algunas categorías y defienden sus identidades queer sin etiquetas, apelando a lo extraterrestre como representación figurativa de lo mutante, de lo que escapa a la identificación. A la vez, felicitan a Dema y a Viedma por el espacio y por el post. Las valuaciones sobre el posteo, sus autores y sobre las disidencias a la cisheteronorma se complementan con la difusión de narrativas basadas en experiencias y vivencias personales que anteponen sentidos positivos en contestación a los comentarios adversos que revisamos en el apartado anterior.

Otro comentarista extiende sus felicitaciones al autor por los debates que le siguieron a su texto, aunque ello no sucede sin resistencias. Citamos un intercambio in extenso:

[BP1407] Juansantaroseño: Muy inteligente el autor de este escrito, que logró buenas discusiones en torno a una temática no muy tratada en los medios en general. Mi opinión es que a la gente, también hablando en general, todavía le sigue causando un morbo especial la sexualidad ajena, la vida de los vecinos, los amigos, hasta de los hijos, cosa que es preocupante y merodea la perversión. Saludable es que cada uno o una haga su vida sin ocuparse en cómo haga el amor el prójimo, eso déjenlo para los programas de chimentos. Saludos desde La Pampa.

[BP1408] Gabriel maluende a Juansantaroseño: El problema Juan, radica en que no se quedan en sus casas haciendo su vida, sino que pretenden imponer a la sociedad que ser homosexual es lo mismo que ser heterosexual, que es natural, y eso lo pretenden imponer a toda la sociedad. Si hicieran sus cosas en su casa, nadie les diria nada... 
[BP1409] pablo a Gabriel maluende: ¿quien no hace sus cosas en sus casas? aca se habla de igualdad de derechos y se visibilizan las orientaciones sexuales y no que hacen exactamente en sus sommiers, esto no es un blog porno, yo ni idea de como garchan las demas parejas q no sean la mia, si se que son, pero no que hacen en detalle, y ia quien le importa?

[BP1410] Fede a pablo: estas siendo muy ingenuo pablo o directamente estas mintiendo. Lo que los homosexuales buscan es torcer la moral tradicional de la sociedad para que acepte la homosexualidad como normal. Es asi o no? entonces lo de hacer sus cosas en su casa no aplica desde hace 1 decada por lo menos.

[BP1411] Josedelbarrio a Fede: Como le comenté a Manuel más arriba, si un homosexual dice públicamente que es homosexual, la mayoría heterosexual se horroriza, lo llama exhibicionista, y le pregunta porqué hace propaganda de lo que hace en su casa cuando los heterosexuales no andan por ahí diciendo que son heterosexuales.

Y entonces, para evitar eso, si un homosexual se junta principalmente con otros homosexuales exactamente para evitar, o por cansancio, de esos comentarios, entonces se los acusa de encerrrarse en un guetto.

Con gente como vos es el cuento de la 'gata Flora'.....

[BP1412] susi a Josedelbarrio: no pibe, exibicionismo es salir publicamente a manifestar tu sexualidad privada, precisamente. No hay heterosexuales haciendo eso, sería tonto.

[BP1413] principe de viana reino navarr a susi: [Los heterosexuales] No necesitáis exhibiros porque no os discriminan en el trabajo, en la escuela, en los derechos fundamentales de tu país. No necesitáis exhibiros porque no os califican de enfermos mentales o de pervertidos ni niegan tu existencia. ¿Como se comportaría tu colectivo en un mundo donde padeceríais todas esas barbaridades? ¿Metido en casa y dejando que todo siga igual?. Respeta nuestros derechos y que existimos y entonces no tendremos que celebrar un día del orgullo gay en público (buscaríamos un lugar privado para hacer nuestra fiesta)

El comentario de Juansantaroseño fue el disparador de varias intervenciones, de las que solo recuperamos seis. En ellas se disputa qué es una sexualidad normal y si la homosexualidad es natural. Por un lado, se dice que los homosexuales buscan cambiar la moral e imponer que su orientación es igual a la de los heterosexuales. Luego se agrega que son exhibicionistas porque manifiestan algo privado en el ámbito público. 
Los contra-ataques de pablo, Josedelbarrio y de principe de viana reino navarr consisten en presentar argumentos contrarios a los de sus interlocutores. Ellos retoman los prejuicios esgrimidos en su contra para rebatirlos y apelan a los topoi de la justicia y del derecho para alegar que la cuestión de fondo es sobre la igualdad de derechos, la discriminación y el sentido político de las Marchas del Orgullo y las estrategias de visibilización. Es decir, se revierte el sentido negativo de ciertos ataques para resignificarlos de manera afirmativa.

En otros textos se defiende al matrimonio y la adopción por parte de parejas del mismo sexo como vínculos caracterizados por el amor y el compromiso; se aduce que estos elementos pueden estar ausentes en algunos matrimonios heterosexuales o que incluso pueden existir casos de abandono o maltrato infantil dentro de familias no homoparentales. Por otra parte, esos usuarios defienden la ley de identidad de género, si bien vimos que hubo casos en los que de manera cortés se solicitaba más información al respecto por no conocer ni haber conocido a personas trans. Simultáneamente, se descarta la idea de que las personas homosexuales, bisexuales o trans son enfermas o perversas, como alegaban algunos usuarios que aludían a sus doctrinas religiosas o que citaban fragmentos de la Biblia, por ejemplo. ${ }^{56}$ En ellos predominan los topoi del derecho, de justicia, de realidad y de definición.

En cuanto a la acusación de "heterofobia", se acudió a la contra-argumentación para contraatacar a otros comentaristas. Veamos un fragmento de una conversación que se desarrolla en el mismo post sobre la bisexualidad:

[BP1619] susi a Josedelbarrio: sociópata es afirmar que cualquier estilo egoísta de manifestacion sexual da lo mismo que ser heterosexual.

[BP1620] carladiaz a susi: claro, los hetero homofobos no son nada egoistas, sobre todo con el projimo que supuestamente deberian amar, segun su librito de cabecera

[BP1621] Susi a carladiaz: ser hétero no te hace fobico a nada por default. Por favor guardate tu heterofobia...

[BP1622] Karen Bennett a Susi: No, pero llamarte Susi te hace estúpida por default

[BP1623] Dixon a Susi: Usted es homófoba, y la heterosexualidad no tiene nada que ver. Yo soy heterosexual y mi hermano es homosexual, ningúno le

\footnotetext{
${ }^{56}$ Nótese que las críticas a la Iglesia o a las instituciones religiosas no fueron tan comunes en BP como sí lo fueron en Tx.
} 
complicó la vida al otro en ningún sentido por causa de esta diferencia, nos respetamos, queremos y ayudamos mutuamente en nuestra cotidianeidad. Es usted la que confunde la heterosexualidad con el odio irracional a las personas que no lo son. Se puede ser $100 \%$ heterosexual feliz y pleno rodeado de familiares y amigos gays y lesbianas.

Susi rechaza la igualación de orientaciones sexuales diversas con la heterosexual y califica como "fóbicos" a los no heterosexuales, a la vez que niega que la heterosexual esté ligada a la (homo)fobia (topos de comparación - diferencia). Pero todo esto es resistido por los comentaristas carladiaz, Karen Bennett y Dixon, quienes le atribuyen a Susi los calificativos negativos que ella les atribuía a los no cisheterosexuales. Pero hay un punto con el que Dixon coincide, y es en que no es lo mismo ser heterosexual que homofóbico; finalmente, el usuario marca su posición discursiva como persona heterosexual que tiene un hermano homosexual al que quiere y concluye en que su interlocutora es homofóbica porque tiene un odio irracional. El relato experiencial y el topos de definición se emplean como respaldo argumentativo del contra-ataque dirigido a Susi en rechazo a la asimilación entre homofobia y heterosexualidad en la medida que, se dice, no hay una relación de causalidad entre ambas. Del mismo modo, los homosexuales no son heterofóbicos por ser homosexuales porque no odian a los heterosexuales, como dice Dixon a continuación:

[BP1703] Dixon a angel: Las personas gays y lesbianas no son heterófobas, no temen, ni odian ni desprecian a nadie por el solo echo de ser heterosexual. Acusar a los homosexuales de fóbicos de los heterosexuales es invertir antojadiza y perversamente el signo de la injuria histórica que padecieron y padecen las personas lgbt. Una forma más de insulto y violencia gratuita contra esta minoría, debería sentir verguenza y reflexionar sobre sus dichos Angel.

Por lo tanto, se sostiene que Susi y angel son homofóbicos no porque sean heterosexuales sino porque son homófobos.

También observamos que las personas LGBTIQ que se sienten violentadas y discriminadas acusan a otros comentaristas de ser homofóbicos, hecho que es resistido y rebatido por otros usuarios. Así, el discurso de la heterofobia funciona de forma análoga al discurso de la homofobia en tanto ambos se usan para atacar interlocutores y clausurar debates, como en estos ejemplos: 
[BP310] C Méndez: Quiero agregar algo para los foristas homofóbicos: La inmensa mayoría de homosexuales provenimos de hogares bien tradicionales y muchos tenemos hermanos e incluso hijos heterosexuales. No somos "diferentes" porque nos maltrataron o nos maleducaron. Salimos así y punto. Lo importante en la vida es ser buena persona, no?

[BP311] claudiogn a C Méndez: el dia que aprendan a usar homofobia como la descripciòn de una fobia, en lugar de usarlo como palabra 'policìa' para desmerecer, agraviar o atemorizar a quienes tengan la ocurrencia de disentir con uds, habràn hecho un gran logro. Se llama falacia del hombre de paja.

[BP312] C Méndez a claudiogn: ¿Entonces, cómo querés que les llamemos? ¿Intolerantes? ¿Nazis? ¿Heterosupremacistas? Estoy abierta a cualquier sugerencia $\ldots$

Más aún, vimos que de modo similar se usa la palabra "homosexual", y más específicamente, la atribución de una homosexualidad reprimida y no asumida. Veamos un fragmento de un intercambio:

[BP669] Lysander a Karen Bennett: sos tan contradictorio como tu apariciencia. ya te respondieron varias veces a una pregunta, que vos mismo decis que te importa un carajo lo que piensen los demas. te dijeron que leas el significado de familia, y todas las familias que se ajustan a esa definicion son las que califican como familia. pareciera mentira, te lo tengo que explicar como a un chico de 5 años...

[BP670] Karen Bennett a Lysander: Lisandra.. Poné tu jeta en el perfil antes de hablar de apariencia contradictoria. Yo tengo la apariencia que me apetece, porque ademas tengo el coraje de pararme frente a todos ustedes que parecen saliditos de adentro de una espantosa fotocopiadora inapagable. Si tenés problemas con las apariencias que no entran en tu comprensión, meté tu horrendo culo familiero en el inodoro y vas a encontrar respuestas. El concepto de tu retrógrada definicion de familia, se reescribió ya hace rato. Mudate a este milenio, marica reprimida

Como se observa, hay comentarios que resisten a los discursos violentos y discriminatorios pero estos también incluyen etiquetamientos, insultos y ataques personales. En el último ejemplo citado se puede ver que Karen Bennett reivindica su derecho a expresar su género a la vez que argumenta a favor de las familias homomater y homoparternales, en rechazo a la exclusión de las mismas de la definición de familia 
(topoi de realidad y de definición). Pero en paralelo descalifica a Lysander y lo llama Lisandra, modificando su género adrede. Es decir, la usuaria que reclamaba que se respetara su identidad de género y que defendía a los homosexuales de los discursos discriminatorios, ahora realiza las mismas operaciones con un sentido diferente para contrarrestar las voces adversas a su posicionamiento discursivo. Por otro lado, la activista trans continua su ataque con otro mecanismo de desprestigio en la web que tiene que ver con el cuestionamiento de la imagen del interlocutor y con su modo de autopresentación en el blog: tanto en este texto como en otros se toman los apodos y las imágenes de avatar como excusas para desprestigiar a los oponentes, ya sea si usan un nombre que no se perciba como real, si no usan ninguna imagen de avatar o si esta no tiene una foto de su rostro. Por último, culmina su texto al calificar a Lysander como "marica reprimida"; esta no fue la única vez que se infiere que las personas que discriminan a los homosexuales son, de hecho, homosexuales. En otros comentarios incluso se ofrecen fundamentos basados en el discurso científico con el fin de respaldar dicha presunción:

[BP1369] aldo: Cuando se tiene bien clara y explorada la propia condición sexual (hétero, homo, bi, tri, etc), se puede entender y respetar la condición sexual del otro (otra vez: hétero, homo, bi, etc). Cuando nos sentimos indignados, ofendidos, asqueados, superiores, críticos, etc. ante la condición sexual del otro, suele deberse a que el otro nos está haciendo de espejo de lo que nos pasa inconcientemente a nosotros mismos. Construimos un sistema represivo-negador imperceptible para nosotros mismos, y el otro lo pone en evidencia. Entonces sacamos solamente el puño, o la lengua, de adentro del placard, para pegarle o insultarlo al que se animó a sacar todo el cuerpo.

[BP1370] C Méndez a aldo: Lo que vos decís se confirma con los resultados de un estudio que se realizó en EEUU: a un grupo de hombres supuestamente heterosexuales les mostraban algunos pornos gay. Antes y después se les hizo un cuestionario y se midieron las reacciones físicas. Resultado interesante: los hombres que antes y después habían afirmado que les daba asco todo relacionado con la homosexualidad tuvieron erecciones mientras que aquellos que tuvieron una actitud indiferente o positiva hacia la homosexualidad no mostraron signos de excitación sexual. Esto afirma que los homofóbicos son en general unos reprimidos.

Acá va un link: https://www.psychologytoday.com/blog/the-bigquestions/201106/homophobic-men-most-aroused-gay-male-porn 
"hombres homofóbicos, los más excitados con porno gay"

Otros discursos de resistencia reclaman el blog como propio; identificamos que existe un sentido de pertenencia a un lugar que se percibe que está dirigido a un "nosotros" no homo/transfóbico conformado en su mayoría por personas LGBTIQ. Este sitio es representado como un espacio de diálogo donde se aceptan las diferencias. No obstante, hay comentaristas que rechazan la presencia de los usuarios que usan el espacio para agraviar a otros, como se manifiesta en los textos que siguen:

[BP276] maria: Por qué la diversidad genera tanta agresión?.

Y no me refiero sólo a la diversidad sexual, ya que también la hay cultural, religiosa, lingüística, etc. Ninguno de estos campos está exento de gente que juzga y sentencia a los demás como si tuviera la verdad (basta con haber estudiado un poco de historia para que nos vengan a la memoria unos cuantos ejemplos).

No es necesario aplastar a otros para sostener lo que uno cree.

Sé que con esto no traigo nada nuevo al ruedo, pero no puedo dejar de preguntarme por qué lo distinto molesta tanto.

Me parece bueno aclarar que la palabra diversidad no tiene, como parecen entender algunas personas, una connotación negativa.

La Real Academia Española la define de la siguiente manera:

1. f. Variedad, desemejanza, diferencia.

2. f. Abundancia, gran cantidad de varias cosas distintas.

Por último, comparto un poco de humor para reirnos y reflexionar sobre el tema: https://www.youtube.com/watch?v=t5h_z8nTSzo

Saludos.

[BP277] Miguel Andrada a maria: Me parece que estas aplicando mal la palabra diversidad, cuando en la sociedad primero que nada se valora si es correcto o positivo tal o cual cosa. Nadie te diria nada si usted como homosexual que supongo es, practica su inclinacion dentro de su hogar, pero si lo practica en un ambiente publico y rodeada de una mayoria que no la tolera ya es otro tema. La gran myoria de la sociedad califica negativamente a la homosexualidad, maxime si se la refriega en la cara de una sociedad que la rechaza, y ese es el punto central, no el de si se tolera la diversidad o no diversidad. En el plano sexual, la palabra diversidad bien empleada se refiere al hombre-mujer y la sexualidad entre ellos. Todo lo demas entra en categorias 
con connotaciones negativas, que no las menciono para que no me censuren el post.

[BP278] Maria a Miguel Andrada: Según su discurso, Miguel, la sociedad nunca se equivocaría. Podría ud. explicarme entonces, sobre la base del mismo razonamiento que despliega en su comentario, el tema del nazismo, por ejemplo? O las cuestiones raciales? Sería muy interesante saber cuál es su postura.

Por otra parte, me gustaría preguntarle a ud. y a todos aquellos que entran a este blog para agredir a los que piensan distinto (y no uso la palabra homosexuales por que no todos los que tienen una postura diferente a la suya, Miguel, lo son) para qué entran a este blog y se indignan con lo que de antemano saben que van a encontrar.

O me van a decir que al hacer click en un blog que se llama Boquitas Pintadas, que se anuncia como gay friendly, que tiene una bandera multicolor y que despliega títulos como "Anita y sus dos mamás", un cuento infantil para pensar las familias diversas, pensaban encontrarse con un detalle del santoral?

Quizás deberían preguntarse, qué tiene que ver con uds. esto que tanto les molesta.

En estos textos se interroga sobre la motivación o el propósito por el cual esos "otros" ingresan "a agredir a los que piensan distinto" y participan en un blog "que se anuncia como gay friendly", como apunta Maria. Esos "otros" son personas vistas como fundamentalistas religiosas, retrógradas, hipócritas, cargadas de prejuicio y de odio, que defienden el ideal de matrimonio heterosexual y de familia heteropaternal y no pueden aceptar el matrimonio entre dos hombres o dos mujeres. Sus posturas son inmóviles, no escuchan argumentos, no saben convivir. Se les atribuye miedo a sentir algo por fuera de la (hetero)norma, motivo por el cual "tienen que venir a agredir, denigrar y sembrar odio donde nadie los llamó", como dice C Méndez en el último comentario. Así, los topoi de la historia, de definición y de realidad anteponen a argumentos basados en definiciones y comparaciones de semejanza y diferencia que son peyorativos respecto a la diversidad sexo-genérica.

La disputa por la apropiación del espacio también se ve en el fragmento de este intercambio:

[BP1704] susana a Dixon: no claro, [ustedes] se inventan blogs como este para integrarse a una mayoría social... tomatelás... no son nada mejor que un ghetto. 
[BP1705] Juan Carlos Díaz a susana: No, no es que no quieran mezclarse o formar parte de la mayoría social, pero si les interesa evitar a esa minoría de gente como vos, que desprecia y que abiertamente demuestra su repugnancia a ellos. No culparía a nadie por eso.

En estos comentarios, susana interviene para cuestionar los objetivos detrás de la creación del blog, que para ella no es la integración social sino la constitución de un "ghetto". Esta idea la rechaza su interlocutor, Juan Carlos Díaz; como puede leerse, coloca a susana dentro de un grupo minoritario que desprecia a las personas LGBTIQ y valúa al blog como un sitio donde hay interés por evitar el odio que proviene de gente como ella. De este modo descarta la acusación de "ghetto" para resignificar el blog en términos afirmativos, como un lugar seguro para gente que no se quiere sentir discriminada.

Nuevamente, se anteponen sentidos sobre el derecho a una vida de discriminación y el derecho a la libertad de expresión. En los comentarios que aparecen a continuación se disputan los límites de cada derecho en relación a la posibilidad de expresar opiniones a favor o en contra de la diversidad sexo-genérica:

[BP636] Javier a Karen Bennett: cierto, es de imbécil agradecer la existencia [tuya] a la heterosexualidad, habrás nacido de un repollo... videla y hitler no fueron muy diferentes a tus planteos en este foro adonde solo sabés descalificar al que opina diferente desde tu pensamiento único.

[BP637] Karen Bennett a Javier: No te equivoques forrito. Yo no descalifico el pensamiento diferente. Ustedes no vienen acá a pensar diferente, sino a negar los derechos de personas que no entran dentro de su modelito heteronormativo. Eso no es 'pensar diferente', eso es violentar los derechos humanos. Y si vos violentas mis derechos humanos en un blog dedicado a personas como yo, desde un perfil oculto, yo, voy a hacer todo lo humanamente posible para agredirte sistemátiamente. Y lo hago sola. NO me valgo del estado. A todos ustedes juntos, me los fumo sola. Un facho, se oculta detrás de las leyes para hacer esto.

En estos comentarios se repite la comparación entre las figuras totalitarias y la descalificación hacia aquel que piensa diferente, acusación que siempre recae en el “otro" discursivo. Pero como señala Karen Bennett, la participación de Javier no es una expresión de un pensamiento diferente sino un intento por coartar derechos de las 
personas LGBTIQ mediante el uso de los topoi del humanitarismo, de la legalidad y el derecho. Al mismo tiempo, representa al blog como un sitio dedicado a personas como ella y, en consecuencia, no a gente agresiva como Javier. Algo similar dice asustado:

[BP1722] asustado: Entré a ese blog porque me lo mencionó una amiga y empecé a leer los comentarios.

Realmente asusta el nivel de agresión que todavía hay contra todo aquel quien es 'diferente'.

¿Qué les molesta si ven dos hombres o mujeres besandose en la calle, si se casan, si crían o adoptan un chico?¿Y si alguién se siente mal en su cuerpo o en el rol que le ha asignado la sociedad, quiénes son ustedes para decirle cómo tiene que vivir su vida?

Cualquier individuo tiene el derecho de ser respetado en su forma única de ser.

En realidad respeto mucho a aquellos que se animan a dar la cara. No tendría que serlo, pero lamentablemente todavía requiere coraje y valor - huevos, si quieren, algo que aparentemente les falta a todos estos homofóbicos que entran a un espacio 'gay friendly' autodeclarado a buscar roña.

Ya con la selección de su apodo y su texto, este usuario muestra su disconformidad con respecto a los comentarios que leyó en BP. Expresa su temor ante el nivel de violencia de las participaciones críticas con las personas distintas (topos de humanitarismo) en un espacio abiertamente gay-friendly y de nuevo pone en tela de juicio las motivaciones de los homofóbicos que participan en el blog para agredir al resto.

Finalmente, en BP observamos que se descalifica a las personas que publican comentarios adversos a la población LGBTIQ con el rótulo de "trolls". Veamos unos ejemplos:

[BP265] Josedelbarrio a claudiogn: "vomitar falacias intolerantes....”? ¿уо? No, Claudio, para vomitar intolerancia alcanza con lo que hacés vos en este blog. En ese campo, sos el hombre-orquesta.

Pero volviendo a tu comentario. Sí, ya sé, sin un padre y madre biológico no hay hijos. No te preocupés, entiendo biología básica. No necesito de un troll que me la explique.

Pero, cuando primero decis que ““‘....todos los niños tienen papá y mamá, menos Anita...." (como si jamás hubieras visto niños abandonados) y después reculas insinuando que te estabas refiriendo a biología básica, demostrás que, como buen troll, lo único que te interesa es atacar y ofuscar. 
Realmente discutir con trolls no tiene sentido, ya que el diálogo constructivo no es el propósito de su participación en un foro, pero al menos es constructivo exponerlos como tal. Además, tu presencia es harta evidencia de que la moderadora no censura (aunque la tentación de hacerlo debe de ser irresitible a veces....).

Gracias por jugar.

[BP2029] Chica Bi: Por el amor de diooooooooos, el 90\% de los comentarios son trolleadas y respuestas a las trolleadas!! No tomen en serio a la gente que entra acá a criticar a la homosexualidad... si entran acá para decir eso es porque buscan molestar y ni ellos mismos creen lo que escriben. Tuve y tengo muchos amigos que lo hacen y son las personas menos homofóbicas que conozco! Lo único que buscan es hacerlos sacar de quicio, les da risa... seguro que luego de comentar una sarta de estupideces anti-gays, van a páginas católicas a comentar con argumentos pro-gays para sacarlos de quicio a ellos también... dejen de darles cabidaaaaa, me aburroooo leyendo esoooooo!! Ocupan toda la página con nada que valga la pena!!!

En estos textos metadiscursivo que manifiesta que los comentarios en este espacio son "trolleadas", para aludir a los mensajes publicados por los trolls. A estos se los caracteriza como sujetos que solo buscan desviar conversaciones y molestar por diversión y, por eso, no vale la pena responderles.

Por último, estos comentarios nos permiten ver que los límites a la libertad de expresión y el derecho a una vida libre de discriminación se disputan permanentemente. Pero dichas negociaciones no están libres de manifestaciones violentas; más aún, algunos comentaristas que resisten a las intervenciones discriminatorias se sirven de insultos, descalificaciones y ataques. Pero no siempre se responde a la violencia con más violencia: hay publicaciones que contestan a los comentarios con contenidos discriminatorios sobre las personas LGBTIQ que condensan representaciones positivas sobre ellas y sobre el reconocimiento igualitario de sus derechos. Además hay otros textos que expresan adhesión o descontento con los artículos o con los comentarios que allí se volcaron y que ninguna de las partes involucradas consideró como violentos. También hay comentaristas que rechazan las representaciones peyorativas empleadas en su contra con argumentos diferentes, disputando sentidos sobre qué es lo normal, lo bueno y lo aceptable, con un uso de los topoi de humanitarismo, de legalidad y derechos, de justicia, de definición, de realidad y de historia. 
En los comentarios que sí son percibidos como violentos por las partes involucradas, se construye y se representa al "otro" discursivo como un troll y como sujeto homofóbico que ingresa a este blog a vomitar su odio y a difundir su moralina católica que cercena los derechos de las personas con sexualidades y géneros no normativos. Algunos de esos comentarios incluyen ataques personales de modos más o menos violentos en contra de usuarios que hubiesen manifestado tener posturas divergentes. Por ejemplo, hay comentaristas LGBTIQ que valúan a otros negativamente y los califican como homofóbicos o como maricones, invirtiendo el sentido de las palabras que se utilizaron en su contra y para violentar a quienes las violentaron.

No obstante, vimos que las personas que se distancian del colectivo LGBTIQ y que son objeto de estas acusaciones las contra-atacan con apelativos diversos que dan lugar a un continuum y a una escalada de violencias, a una cadena continua de textos violentos que tienen destinatarios múltiples y cambiantes, donde el destinatario se modificará según se muestre próximo o lejano a un grupo identitario diferente al del comentarista. Así, en BP identificamos procesos violentos inter-grupales con aristas variables y múltiples, que pueden ser utilizadas a favor o en detrimento de los derechos de las personas LGBTIQ y que obstaculizan el pleno ejercicio del derecho a la libertad de expresión de los participantes del blog.

\subsubsection{Tod@s}

Al igual que en el blog de Dema, en Tx hay prácticas de contestación que proponen sentidos alternativos a los hegemónicos con respecto a las personas con géneros y sexualidades disidentes. Vimos que los usuarios escriben opiniones favorables sobre los posteos en línea con el posicionamiento del autor y que responden a los textos de otros comentaristas para manifestar su adhesión o distanciamiento. En ambos espacios, las personas que defienden los derechos de las personas LGBTIQ esgrimen argumentos a favor de políticas o proyectos que les incumbieran y critican a quienes publican dichos que afectaran sus derechos.

En primer lugar, notamos que se adjudica un componente homo o transfóbico a la Iglesia, a los fundamentalistas religiosos y a los interlocutores que rechazan las políticas en defensa de las personas LGBTIQ o que detentan representaciones discriminatorias sobre ellas. En simultáneo, esta acusación opera como parte de una 
estrategia de ataque personal para desprestigiar a los contrincantes discursivos directos (los comentaristas) y los indirectos (la Iglesia, los creyentes fundamentalistas, los lectores de $\mathrm{TN}$ ), como sucede en el intercambio que extrajimos del post de Zamudio:

[TX923] Miguel Yamantak a Luis Fernando: No olvidemos la historia. La Iglesia católica ha promovido la violencia contra todo lo que no es de su agrado, la iglesia ha instigado guerras, cruzadas, genocidios, homofobia y misoginia, ha encarcelado y torturado a lo largo de toda su existencia, ha esgrimido enorme poder, recordemos a la Santa inquisición y, más recientemente, a la sorprendente abundancia de curas pederastas. Reconozco la santidad de la Iglesia pero también la paradoja de que entre sus filas, los ambiciosos y oportunistas son muchos, los hombres somos pecadores por naturaleza. ¿puede una santa institución conservar su santidad si está en manos de los hombres?

[TX924] Andrea D' Diaz a Luis Fernando: Homofobico de mierda personas como tu son las q promueven la violencia hacia la comunidad homosexual.. que triste q usted piense asi.. pidale a dios que un hijo suyo sea gay.. suerte

En el primer comentario, su autor se sirve del topos de la historia para aludir al caso de Zamudio, a las creencias religiosas de sus agresores, a la Iglesia y a sus adeptos con el fin de argumentar que los últimos son promotores de violencia. El segundo, además, insulta a Luis Fernando y lo acusa de homofóbico y violento.

Veamos más ejemplos. En el marco del artículo "El diputado y activista gay brasileño Jean Wyllys le responde al papa Benedicto XVI" (14/01/2012), Bimbi traduce una columna que escribió el diputado con respecto a un discurso papal en defensa del modelo tradicional de familia (heterosexual) y en rechazo del matrimonio entre homosexuales. Allí se desarrolla el siguiente diálogo:

[TX319] Ernesto Lamuedra: Aquí un enlace sobre lo que realmente dijo Benedicto XVI no la tergiversación de titulares de la prensa mundial para producir histeriqueo anticatólico. Baste decir que no menciona ni una sola vez las palabras "matrimonio homosexual", "matrimonio gay" ni siquiera homosexualidad y que sí se refiere a los flagelos de la guerra, la pobreza, la persecusión de minorías, la educación y el obviamente el derecho a la vida contra el crimen del aborto y la defensa de la familia conformada por el matrimonio entre el hombre y la mujer. https://www.aciprensa.com/Docum/documento.php?id=433 
Respecto a los errores más gruesos de la exposición del Diputado Wyllys (renuncio a refutar todos so pena de poner un comentario tan largo como la entrada del blog) me restrinjo a referirme a lo siguiente:

1) Jamás la Iglesia Católica dijo que el matrimonio interracial fuera "contrario a la ley de Dios". Por el contrario una de las enormes contribuciones de la evangelización en la conquista española de América fue la activa participación de la Iglesia en el fomento del mestizaje. El matrimonio interracial siempre estuvo permitido en nuestro país y en todos los países de América Latina.

2) Durante la vigencia del mal llamado 'matrimonio religioso' en la Argentina, es decir el vigente en el Código Civil antes del dictado de la ley 2393, jamás se prohibió casarse a los Evangélicos (ni a los miembros de ninguno otra religión). Lo únicoo que no permitía era el matrimonio de un Católico con una persona de otra religión sin tener dispensa de la Iglesia Católica.

3) Lo de siempre: el matrimonio "igualitario" es en realidad desigualitario para los niños, al privar a algunos de su derecho a tener padre y madre.

[TX320] Nataniel Costard a Ernesto Lamuedra: Cuántos niños y niñas maltratados por sus padres o desatendidos por sus madres cambiarían el derecho a tener dos progenitores de distinto sexo que los abandonan, por el de tener dos personas de cualquier sexo que los amen como a lo más importante del mundo.

El primer usuario se muestra en línea con la postura papal y reafirma la constitución familiar tradicional hegemónica, binaria y con descendencia. Luego desacredita al matrimonio igualitario, al que califica como "desigualitario" porque amenaza los derechos del niño (topos de peligro). Este es el argumento que discute Nataniel Costard, quien se apoya sobre la protección de los infantes (topos del derecho) para argumentar a favor de la adopción por parte de parejas del mismo sexo en rechazo a la valoración de su interlocutor. Pero este comentarista continúa discutiendo con Ernesto Lamuedra, al que le destina el siguiente texto:

[TX354] Nataniel Costard a Ernesto Lamuedra: Es curioso lo difícil que nos resulta imaginarnos que haya gente que tenga una opinión distinta a la que nosotros tenemos. Yo, por ejemplo, me lo imagino a usted muy solitario, sentado frente a la computadora durante largas horas, buscando en google todo lo que haya sobre homosexualidad y con un enlace directo a wikipedia, tratando de refutarlo todo, y resistiéndose a la tentación constante de volver a abrir esa página de porno gay que tanta culpa le da disfrutar. Usted, por su lado, nos imaginará trabajando en una oficina, cobrando un sueldo mensual para intentar 
desacreditar a una institución multimillonaria y milenaria a fuerza de comentarios y posteos en blogs. ¡Así somos las personas!

Paradójicamente, en este comentario se alude a la presunta homosexualidad reprimida de los interlocutores con el fin de atacarlos y desacreditar su postura negativa sobre las personas LGBTIQ, tal como vimos que ocurría en BP. Además, se representa a los comentaristas como oficinistas que cobran un sueldo para publicar comentarios y desacreditar instituciones; hablaremos sobre esto más adelante.

La homosexualidad como un juicio valorativo negativo fue una de varias de las nominaciones y predicaciones peyorativas vertidas sobre el colectivo LGBTIQ, motivo por el cual en Tx circularon sentidos contrarios a esa premisa:

[TX581] hugo laguna a Daniel Leone: la homosexualidad no es una enfermedad (ponte al día) pero la homofobía si

[TX1842] Alonso de Blanco a TuPadreCDTM: Antinatura es que estes sentado frente a una PC escribiendo... lo que se cura son ENFERMEDADES... y la homosexualidad NO LO ES:... lo dice la misma ciencia que te permite estar vivo, que investiga y cura las enfermedades que te permiten seguir vivo... aparte... que obsesión con los culos ajenos! Todos los que reducen la homosexualidad a meter el ojo en el culo ajeno no tienen la menor idea de nada.... de las lesbianas que tiene para decir?

En ambos textos se resiste a la idea de que la homosexualidad es una enfermedad o una perversión antinatural. Más aún, se dice que la homofobia es una enfermedad y que, como tal, se puede curar (topos de definición)

Pero vemos que a veces quienes defienden al colectivo LGBTIQ emplean nominaciones peyorativas asociadas a la homosexualidad con el fin de atacar las personas que no formaran parte de él y que primero hubiesen ofendido a sus integrantes. Lo vimos unas páginas atrás en el comentario [TX924] y en algunos intercambios que transcurrieron en el artículo sobre Zamudio; transcribimos uno a continuación:

[TX861] Guest a Luis Fernando: Por enfermos y retrogrados como tu el mundo esta tan podrido, celebrale la pedofilia a tus curas, apoya sus robos y mentiras, felicitalos por ser delincuenetes y enfermos, quizas asi seas feliz, podrido por dentro y un anormal mas que solo ocupa aire. 
[TX862] Maria Laura Jauven Balderrama a Guest: otro insulto mas enfermos, retrogrados, ladrones, mentirosos, enfermos, podridos, anormal, y si ocupo el aire bueno me resigno.. decime a que clinica mental me interno porque aparentemente estoy enferma.

[TX863] lucas_m a Maria Laura Jauven Balderrama: Y decinos donde se internan los gays prque segun tu iglesia que tanto defendes somos exactamente todos esos nombres que te estan diciendo a vos!!! y que lo gracioso aca es que te lo dicen a vos!!! y vos por retrasada metes en la bolsa a todos los " heteros cristianos " para no sentirte sola anda a saber... jajaj

[TX866] SofiaHernandezPerez a Luis Fernando: Luis Fernando que poco informado esta acerca de los avances de la ciencia, se nota por sus argumentos que solo concibe las verdades de la iglesia, lea literatura cientifica y descubra que ya no estamos en la epoca del oscurantismo de la edad media, donde la religion le costo 1200 años de atrazo a la tecnologia y la ciencia, y quiza si sabe interpretar lo que lee vera que con pruebas cientificas y no con invenciones imaginarias de un Dios de papel como lo ha hecho la religion la homofobia la padecen los homosexuales reprimidos, depronto descubra que ud hace parte de uno de ellos.

Aquí, el primer comentarista y el tercero denuestan a Luis Fernando y a Maria Laura Jauven Balderrama utilizando términos vinculados a la enfermedad y se ataca a la Iglesia y a los católicos y cristianos por considerarlos perversos, delincuentes, anormales, pedófilos, mentirosos y ladrones - términos que, como señala lucas_m, fueron usados para aludir a las personas LGBTIQ en otros comentarios y también a lo largo de la historia. Por su parte, SofiaHernandezPerez contrapone ciencia y religión, coloca la homofobia del lado de la segunda y dice que Luis Fernando es un homosexual reprimido.

De este modo, los usuarios que se distancian de las personas LGBTIQ y que publicaron intervenciones percibidas como violentas por ellas reciben a cambio burlas, descalificaciones e insultos, como se ve en estos comentarios:

[TX377] Soledad Rojas Herrera a Bruno Bimbi: Porque no respetan a Dios...no tienen miedo cuando se mueran, porque a los gays el demonio se lo va a llevar con él...hay que estar a la par de Dios orando y pidiéndole cosas, sí le pides que te quite ser gay El se lo quitara, porque esto es PECADO....yo voy a pedir por los gays para que se unan a Dios... 
[TX389] Rodriguez Lore a Soledad Rojas Herrera: jajajajajajajaa sos patetica ydiscriminadora

Y aquí:

[TX2362] ROLO a Dario: JAJAJAJAJAJAJJ TOMATELA SI TE GUSTA LA PORONGA BANCATELA, ACA NO TE VENGAS A HACER LA QUE NO ELEGIS. LOS TRAVESTIS SUBSIDIADOS SON MAS "VOTOS" COMO LOS NEGROS CON PLANES Y LOS PENDEJOS FUMAPORROS CON NETBOOK.

[TX2363] ODIO A LOS FACHOS a ROLO: TE SALIO EL MILICO DE ADENTRO ...

LA GRAN CONCHA DE TU MADRE FORRO HIJO DE MIL PUTA!!!

Las prácticas violentas en el blog son multidireccionales, como también vimos en otros textos. Pero notamos que la violencia como reacción o defensa de las personas LGBTIQ no está mal vista por el resto de los usuarios que las apoyan. En todo caso, se argumenta a su favor con textos como este: ([TX417]) Patrick Evans Lavigne a Alicia Giacomini: "tenemos todo el derecho d ofender y reclamar cuando fuimos primero ofendidos". Pero algunos intervienen para desescalar la agresión, como hace Bimbi a continuación:

[TX959] Pe Hache: alguien le puede hacer lo mismo aluis fernando por el solo hecho de que se llame fernando? a ver si le gusta [TX960] Luis Fernando a Pe Hache: Gracias por tus buenos deseos.

[TX961] Bruno Bimbi a Pe Hache: No, Pablo. Respondamos con argumentos. Saludos.

Pese a ello, los atributos de violencia y discriminación recaen tanto sobre las personas LGBTIQ como quienes se distancian de este grupo, como sucede aquí:

[TX1226] Marta Monzon: [sobre Bruno Bimbi] ¡iQUE BLASFEMO...DIOS PERDONE A ESTA PERSONA, TAN INTRIGANTE Y FABULA DORA ,IRRESPETUOSO...SIEMPRE PENSAMOS DE LOS DEMÁS LO QUE SOMOS EN REALIDAD .

[TX1227] Juan Jo a Marta Monzon: esto se llama LIBRE EXPRESION , catolicos conservadores, 
[TX1229] Guest a Juan Jo: libre expresion???? si te dijera" boludo" tambien es libre expresion???? Seguro que saltarías como leche hervida...o no ???una cosa es libre expresion y otra la injura

[TX1230] Martin Caballero a Guest: La legislación avala el derecho de parodiar a las personas públicas. Se da por hecho que una persona pública puede despertar reacciones así. No te olvides que el papa tiene más poder sobre nosotrxs que al revés. Es una cuestión de equilibrios.

Por cierto, durante la campaña por el matrimonio igualitario, nos llovieron insultos y mentiras por parte de lo peor del cristianismo, y se escudaban (injustamente) en la "libre expresión".

En este intercambio, se califica a las personas LGBTIQ como "injuriosas" $y$ "blasfemas" por atacar a la Iglesia, a Dios y al ex Papa. Pero estas responden refiriendo a la libertad de expresión como derecho aludiendo al topos de legalidad y el derecho. Asimismo, se resalta que en las relaciones de poder, las palabras del Papa tienen un peso mayor que el resto.

Paralelamente, se emplean los términos "discriminación" y "violencia" de forma homogénea y homogeneizante para abarcar todas las experiencias de vida y así obturar la comprensión sobre la especificidad de los procesos de vida de las personas LGBTIQ en tanto se sostiene que existen otros modos de discriminación que recaen sobre otros sujetos, como vemos a continuación:

[TX984] Maria Laura Jauven Balderrama: donde lo dice??? o sea que si yo no quiero o rechazo a un ladron que entre a mi casaa lo estoy violentando psicologicamente???

[TX985] Eugenia Dámaris a Maria Laura Jauven Balderrama: La DIFERENCIA, es que un LADRÓN: Está cometiendo un delito, está apropiándose de algo, que no le corresponde. Está privándote de algo que lo conseguiste vos, que salió de tu esfuerzo. Está MOLESTÁNDOTE. Se está metiendo con VOS. Te está faltando el respeto. Y un HOMOSEXUAL: No te afecta en nada a vos. No te daña. No te cambia nada. Ni transforma nada en vos. No te está faltando el respeto. No se está metiendo con VOS. ¡TODO LO CONTRARIO! Esta metiéndose con el mismo, con algo que le pertenece, algo que es suyo, algo con el que es el único que tiene derecho a HACER lo que QUIERA.... 
* A Un LADRÓN lo tendrías que rechazar. Ya que EL te esta violentando psicologicamente.

* A Un HOMOSEXUAL No lo tendrías que rechazar. Ya que el no te esta violentando de ninguna manera, ni física, ni psicológica.

iiiiiii Maria, maria COMO TE EQUIVOCAS !!!!

Lección del día.

Me dan asco las personas como vos. No deberían considerarse personas.

Maria Laura Jauven Balderrama usa la palabra "discriminación" en un modo laxo como sinónimo de "diferenciación", a la vez que compara y equipara a los homosexuales con delincuentes y a las personas trans con gente que dice que no consiguió algunos trabajos por tener hijos y ser mujer con el fin de expresarse en contra de la ley de cupo laboral trans, como si fuese un beneficio o un privilegio. En respuesta, Eugenia Dámaris pone en circulación sentidos afirmativos de la diversidad sexogenérica, en oposición a su discriminación (topos de justicia). Enfatiza ciertas palabras y expresiones mediante el uso de las mayúsculas y de signos de exclamación para reforzar sus argumentos, aumentar la fuerza ilocutiva del texto y manifestar su valoración sobre el tópico en cuestión y sobre su interlocutora directa. Expresa que su interlocutora le da "asco" y advierte que no se la debería considerar persona - operaciones que, es sabido, han recaído sobre las personas LGBTIQ.

Por otra parte, en el artículo sobre el proyecto presentado por Rachid para dar un subsidio a las personas trans, encontramos comentaristas que apoyaban el otorgamiento del subsidio o que proponían otras alternativas para mejorar sus condiciones de vida. Entre esos comentarios hallamos usuarios que manifestaban su adhesión a la postura de Bimbi y se distanciaban discursivamente de quienes se opusieran al otorgamiento del subsidio, como ocurre en este ejemplo:

[TX2757] Martín Lasarte: Me parece excelente este artículo, Bruno, y es espantoso que el $90 \%$ de los comentarios sean de gente que no lo leyó y opinan con una agresividad que delata a las claras su transfobia. Es gracioso que los mismos que se escandalizan porque el Estado porteño (ni siquiera nacional) podría dar un subsidio de 2.000 pesos a 100 o 200 personas no digan nada cuando el mismo Estado otorga millones en subsidios a la Iglesia Católica.

Aquí Martín Lasarte valúa negativamente al noventa por ciento de los participantes, a quienes acusa de no haber leído la nota y de ser agresivos y transfóbicos; asume que si 
hubiesen leído el artículo, habrían cambiado su opinión. Con una mirada humanitarista, coloca el origen de la homo o transfobia en relación con la Iglesia católica por un lado y con la doctrina religiosa por otro. En este sentido, coincide con otros usuarios que se identifican como creyentes y otros que dicen ser ateos, que ven que el fundamentalismo religioso es la base de los discursos de odio contra las personas LGBTIQ.

Pero la responsabilidad no recae solo en la Iglesia católica sino también en el Estado, que le otorga subsidios y que pone trabas a la hora de llevar adelante políticas reparatorias para contrarrestar la historia de violencias que sufrieron las personas trans, como se argumenta en este texto:

[TX2504] Gonzalo a lou: El rechazo y asco social de gente como la mayoría que comentó esto les obliga a trabajar de eso [de prostitutas], simplemente se trata de igualar a través de una "desigualdad", son personas que sufrieron maltratos institucionales, etc. Igualdad es tratar de igual forma a personas que estén en las mismas condiciones. Es decir, hay que ponerlos en las mismas condiciones que los demás, igual esto no quiere decir que nos olvidemos de otros sectores que también necesitan ayuda, (que al fin y al cabo es ayuda) si ni con $\$ 2.000$ nadie se hace millonario, menos con $\$ 1200$. Saludos

Gonzalo se sirve de los topoi de humanitarismo, de justicia y de realidad para indicar por qué es importante dar una ayuda económica a las personas trans en situación de vulnerabilidad para que estén en las mismas condiciones que el resto de la sociedad. Para él, las travestis que se prostituyen han sufrido violencia institucional como consecuencia del rechazo y el asco social.

Luego, hay personas que refutan la premisa de que haya igualdad de oportunidades en el mercado laboral para las personas con identidades, corporalidades y prácticas sexoafectivas no normativas:

[TX2309] wanda a Dario: y a mi me viene de nacimiento ser mujer, ser hetero, puedo trabajar y ellos [las personas trans] tambien, que tiene que ver? cuantas veces tuve que dejar a un lado el tema de que tenia una hija para ser contratada en una empresa? muchas, todas!

Me gane los puestos demostrando que soy capaz y trabajadora.

[TX2310] Cristian Cuenca a wanda: pero a vos no te discriminan por tu genero o eleccion sexual cuando vas a una entrevista ,tuviste estudios no te echaron de 
tu casa ni estuviste en la calle y si ya te cuesta asi sin que te discriminen imaginate hay que pensar antes de hablar por hablar

Como vemos en el segundo comentario, se ponen en circulación sentidos alternativos con respecto a las personas LGBTIQ, sobre todo de las personas trans y travestis, representadas como personas que sufrieron de discriminación en el ámbito laboral, educativo y familiar, a diferencia de las personas cisgénero . A la vez, se argumenta que las personas trans no eligen serlo, como se discute en los siguientes escritos:

[TX2278] Sebastian Flores a Sol Minoldo: 1) El travesti es travesti porque lo decidio asi, no deberia tener un beneficios solo por ser trava. Podrian hacer muchas cosas mejores con esa plata, y estoy seguro que eso lo tenes claro. Y si pensas lo contrario, apuesto a que no conoces la realidad de los colegios y hospitales, que es lo mas importante para que un pais funcione, y al mismo tiempo que es un derecho de todos que funcione.

2) El sueldo minimo de los jubilados es de 3200 pesos, a vos te parece que una persona mayor que laburo toda su vida cobre eso (que en mi provincia no alcanza ni para el alquiler de un monoambiente) y que un travesti cobre lo mismo solo por ser travesti?

3) Definitivamente no sabes ni la realidad de las escuelas privadas, NO EXISTE EL PARO EN LAS PRIVADAS.

[TX2288] Dario a Sebastian Flores: 1) EL TRAVESTI NO ES TRAVESTI PORQUE LO DECIDO. NO HABRÁS LEÍDO EN TU VIDA NADA SOBRE GÉNERO Y SEXUALIDAD, PERO ESO NO SE ELIGE, VIENE DE NACIMIENTO. LA CUESTIÓN DE CADA UNO ES ACEPTARLO O NEGARLO. AL MENOS ELLAS TUVIERON LA VALENTÍA DE ACEPTARLO.

2) NADIE CREO QUE NIEGA QUE LA JUBILACIÓN MÍNIMA ESTÁ MUY BAJA, DEBERÍA SER MAYOR PORQUE LOS ABUELITOS ASÍ NO PUEDEN VIVIR.

3) LA COSA NO ES...SOLO POR SER TRAVESTI, ES PORQUE VIVEN SIENDO EXCLUIDAS NUESTRAS SOCIEDADES, MALTRATADAS, Y DENIGRADAS. ESA ES LA CUESTIÓN.

[TX2658] Guest a Guest: Si hubieras leído media nota (que de haberlo hecho, la hubieras leído toda) al menos, comprenderías y entenderías porqué tus abuelxs pudieron trabajar de lo que se les cantó y porque ahora, no necesitan un subsidio. 
Es muy irónico, que, antes de comentar que los argentinos laburen no hayas leído la nota (que es más o menos lo mismo; igual te dejo la imagen que resume bastante bien la nota y quizá te ayude a comprender más.

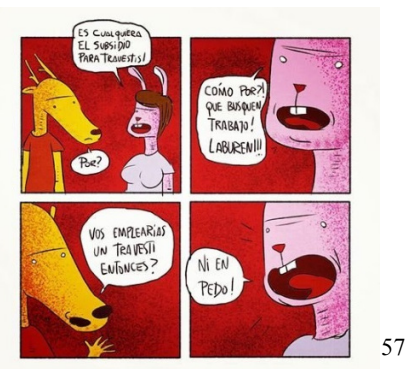

Aquí nuevamente se describe a las personas travestis como personas valientes que fueron excluidas, maltratadas y denigradas y se avala el otorgamiento del subsidio (topos de humanitarismo). Además, en el tercer comentario se incorpora una viñeta cómica para ilustrar y resumir la paradoja de la aceptación o tolerancia social hacia las personas trans que se plasmó en los debates de Tx: se rechaza el subsidio, se espera que busquen trabajo, pero se admite que no se les daría empleo.

En suma, identificamos que en Tx hay un grupo mayoritario de personas cisheterosexuales que se autorrepresenta como un sector vulnerado ante el reconocimiento de los derechos de las personas LGBTIQ. Las personas cisheterosexuales dicen ser las víctimas de la discriminación y del abandono del Estado, reapropiándose de las experiencias de vida de discriminación y violencia que históricamente sufrieron las personas LGBTIQ. En consecuencia, los comentaristas que defienden los derechos de las últimas ponen en circulación sentidos contrahegemónicos de la disidencia sexo-genérica con argumentos basados en los topoi de humanitarismo y de justicia, de legalidad y derechos, de realidad, de historia y de nominación. A su vez, responsabilizan al Estado y a la Iglesia católica y a los fundamentalistas religiosos por las vejaciones acaecidas en contra de la población LGBTIQ dado que el primero no realiza las acciones necesarias para paliar su condición de vulnerabilización y los segundos son promotores de discursos de odio, como argumentan los usuarios. En paralelo, las personas LGBTIQ se reapropian de los términos utilizados en su contra y los emplean para contra-atacar a los sujetos no-trans y no-homosexuales que las violentan, operación que retroalimenta el continuum de violencias similar al que

\footnotetext{
${ }^{57}$ En la viñeta cómica hay dos hablantes, un perro y una coneja. En el primer cuadro la coneja dice: "Es cualquiera el subsidio para travestis!, y el perro pregunta: "Por?". En el segundo cuadro, ella contesta: "Cómo por qué?! Que busquen trabajo! Laburen!!!". En el tercer recuadro, el perro le pregunta: "Vos emplearías un travesti entonces?". En el último, ella responde: “Ni en pedo!”.
} 
observamos en nuestro análisis en BP. Vemos que las personas ajenas a la población LGBTIQ equiparan las formas de discriminación y violencia sufridas por este colectivo con otras modalidades de exclusión que afectan a personas no-trans y no-homosexuales. Esto da cuenta no solo de las representaciones que circulan sobre las personas LGBTIQ sino también de las representaciones sociales en el marco del contexto sociohistórico en el que se publican los comentarios en relación con un entorno mediático e institucional en el que se inscribe la participación de los lectores de $\mathrm{TN}$, en línea con una política editorial más distante a la que propone Bimbi y más próxima a la que se dice que tiene el Grupo Clarín, como veremos luego.

\subsubsection{Conclusiones provisorias}

Tanto en BP como en Tx hay comentaristas que participan mediante la publicación de comentarios donde evalúan positivamente al blog, los posts, sus autores y los textos de otros usuarios, así como las demandas de las personas LGBTIQ. Ponen en circulación sentidos afirmativos de la diversidad sexo-genérica y reivindican sus prácticas identitarias, deseantes, afectivas y corporales; esto es, sus derechos a ser y hacer. Pero también hay comentaristas que expresan su disgusto y su desacuerdo con los discursos que profesan los portadores de las cruzadas anti-queer y que, en respuesta, los burlan y los insultan. Nuestro análisis nos permite ver que hay comentaristas en BP y en Tx que ponen en circulación sentidos contra-hegemónicos sobre la disidencia sexogenérica para velar por sus derechos. Estos discursos no provenían únicamente del colectivo LGBTIQ sino también de personas que expresamente se identificaban como heterosexuales y en algunos casos creyentes. En ellos se rechazaban los juicios de que las personas LGBTIQ eran enfermas y perversas, a la vez que se acudía a otros contraargumentos sobre la responsabilidad eclesiástica respecto a las ideologías homo y transfóbicas, sobre la postura de otros lectores que eran creyentes y/o heterosexuales y sobre el rol del Estado. En ellos pudimos identificar que los comentaristas que resistían a los comentarios cisheteronormativos se identificaban con la postura de Dema y Bimbi en cuanto a asuntos como la protección de los disidentes sexo-genéricos o de propuestas de ley como el proyecto de la legislatura porteña para otorgar subsidio para las personas trans que tuvieran una condición socioeconómica desfavorable y que tuviesen 40 años o 
más. ${ }^{58}$ Se dice entonces que las personas homosexuales no son perversas ni enfermas, que las travestis quieren trabajar y que es la sociedad la que las relega al lugar de prostitutas o trabajadoras sexuales al no aceptarlas en otros puestos de trabajo. En ambos blogs se responsabiliza al Estado, a los fundamentalistas religiosos y a la Iglesia católica por la difusión de discursos de odio, aunque en Tx esto aparece con mayor frecuencia que en BP dado que las temáticas de los posts de Bimbi versan más sobre la religión que los de Dema. Los reclamos sobre el Estado, en cambio, aparecen entre quienes violentan a la población LGBTIQ y entre quienes la defienden: los últimos alegan que el Estado subsidia a la Iglesia y no fomenta medidas socioeducativas o políticas inclusivas que conduzcan a una transformación sociocultural para que se acepte a las personas con orientaciones sexoafectivas e identidades y expresiones de género disidentes.

A comparación con los comentarios que analizamos en el apartado anterior, en estos notamos que hubo una tendencia a emplear los topoi de humanitarismo, de justicia $\mathrm{y}$ de derechos con el fin de respaldar los pedidos de reparación y reconocimiento igualitario de derechos; es decir, predominaba una perspectiva afín a la de los responsables del blog en tanto los usuarios próximos a la comunidad LGBTIQ profesaban valores e ideales similares a ellos desde un lugar de reconocimiento e igualación de derechos. Por el contrario, quienes hablaban en su contra, como vimos, hablaban desde un posicionamiento que evidencia las diferencias y que acentuara la desigualación de esas personas. No obstante, si bien las personas LGBTIQ y sus aliados demandaban el respeto y goce de derechos para que haya una igualdad formal con respecto a sus pares cisheterosexuales, observamos que ellas publicaron comentarios percibidos como violentos por sus receptores. Dicho de otra manera, cuando las personas LGBTIQ o afines sentían que había usuarios que las agredían o que

\footnotetext{
${ }^{58}$ Como revela un informe del Observatorio Nacional de Crímenes de Odio LGBT publicado por la FALGBT (2017), se registraron 31 crímenes de odio en 2016 en todo el país. 24 víctimas eran mujeres trans, de las cuales 12 fueron asesinadas o murieron como producto de agresiones violentas dirigidas a lesionar sus derechos y a aleccionar a potenciales víctimas. La franja etaria más afectada iba entre los 30 y 39 años de edad, lo que corrobora la baja expectativa de vida de las personas trans. Las áreas geográficas donde se perpetraron dichos crímenes fueron principalmente zonas urbanas que reciben migrantes: la provincia de Buenos Aires, la Capital Federal y la provincia de Salta. De todos modos, sus autores advierten que el relevamiento no es preciso ya que los datos disponibles obtenidos de informes policiales y artículos periodísticos responden a injusticias legales y a los estereotipos de los funcionarios y de los agentes que reciben e investigan las denuncias. Esto puede conducir a rotular la muerte de una mujer trans sin respetar su identidad de género o a catalogar un crimen de odio como asalto, robo o como "crimen pasional".
} 
vulneraban sus derechos, les respondían con descalificaciones, gritos, insultos y amenazas.

Si tomáramos todos los comentarios con los que se describió a los comentaristas agresores ajenos a la población LGBTIQ, se construiría una imagen de un sujeto homo $\mathrm{y}$ transfóbico, que tiene un odio irracional contra homosexuales y travestis y no respeta sus derechos. A la vez, se dice que ese usuario es un católico retrógrado que ignora los avances de la ciencia en materia de teorías sobre géneros y sexualidades porque solo cree en la palabra de Dios y la Biblia. Defiende un modelo de familia tradicional y reniega del derecho de parejas del mismo sexo a casarse y adoptar, a pesar de que hay parejas heterosexuales que maltratan y abandonan a sus hijos. Ese usuario es asqueroso, egoísta, violento, intolerante, discriminador; es un nazi, un milico, un fascista, un nazi, un supremacista heterosexual. Entra a los blogs para agredir a quienes piensan distinto y a promover la violencia contra los homosexuales. Pero también es perverso y enfermo porque se preocupa por la vida íntima de los homosexuales y por lo que ellos hacen en la cama. Más aún, es un homosexual reprimido, una persona que secretamente disfruta del porno gay. En cambio, las personas LGBTIQ que argumentan a favor de las leyes que avalan y protegen sus derechos, presentan a las travestis y mujeres trans como personas valientes y con coraje que asumieron su identidad de género a pesar de la violencia institucional que sufrieron. Se dice que fueron excluidas de sus casas, del sistema escolar y del mercado laboral y que no tienen otra opción más que trabajar en la prostitución. Los homosexuales y las lesbianas, por su parte, son personas capaces de amar y criar hijos, a veces mejor que las parejas heterosexuales. No son enfermos ni perversos, aunque reivindican su derecho a ser raros y monstruosos. No son heterofóbicos ni blasfemos ni injuriosos; en todo caso son violentados por su orientación sexual y por eso realizan marchas y crean blogs como estos, para visibilizar sus demandas y evitar a quienes los agreden.

Ahora bien, si en el apartado anterior vimos que en algunos textos se representaba a las personas LGBTIQ como seres intolerantes y violentos, algunas de las contestaciones que les merecieron llevaron a reforzar dichas sentencias. Y si dijimos que los usuarios que se mostraban contrarios al reconocimiento de los derechos de las personas LGBTIQ se servían de la violencia para defender algo que sentían como propio atacando a quien percibían como amenaza, del mismo modo los usuarios que sienten el blog como propio actúan de manera similar en pos de protegerlo y protegerse de los sujetos que participan para manifestar su rechazo hacia ellos y hacia sus 
reivindicaciones. Claro que no todo es violencia y hay intercambios de opiniones divergentes que no son vistas como violentas por las partes intervinientes. Pero sí es menester señalar que en ambos espacios identificamos procesos violentos intergrupales, dirigidos desde o hacia las personas LGBTIQ. En ocasiones, ellas responden a la violencia con más violencia, alimentando un círculo vicioso de violencias que se no parecen tener fin en la medida de que surgen como respuesta y tal vez como reacción ante las violencias sufridas de antemano. Por lo tanto, los comentarios de resistencia de los foristas LGBTIQ y de sus defensores constituyen no solo propuestas de sentidos alternativos y contra-hegemónicos de la cisheteronorma sino que también operan como mecanismos de defensa ante una otredad percibida como amenazante y peligrosa.

En consecuencia, las personas LGBTIQ, como quienes no lo son, representan a un "otro" agresivo y violento, que busca alterar el orden de cosas: para las personas LGBTIQ, los agresores cisheterosexuales y la mafia eclesiástica profesan discursos de odio y quieren menoscabar sus derechos, obstaculizar el pleno ejercicio de los derechos consagrados y obturar el proceso para lograr el reconocimiento de otros. En cambio, en el sentido inverso, se dice que las personas LGBTIQ y su lobby gay quieren imponer su moral a toda la sociedad y subvertir las tradiciones de la gente "normal". Tanto los primeros como los segundos dicen que los "otros" son asquerosos, enfermos, perversos, amorales, discriminatorios, (hetero/homo)fóbicos y violentos. Las mismas palabras, sentidos contrapuestos: la inversión de retórica de la inversión, por un lado, y la defensa del derecho a ser invertido, por el otro. Ambas partes ofrecen argumentos sobre por qué sus solicitudes son válidas y por qué la de los otros no. Además, reconocen o adjudican la violencia a un otro externo para justificar la propia, aunque esta no es vista como violenta; en todo caso, se la considera una forma de violencia legítima.

Como dijimos, la legitimación de las modalidades de la violencia responde a factores circunstanciales ligados al espacio, al tiempo y a los participantes del proceso interpretado como violento. Siguiendo a Evangelina Caravaca (2014), esto expresa problemáticas sociales en un marco de transformaciones socioculturales veloces, que se caracterizan por el declive de la autoridad estatal, por una crisis económica y por una crisis moral donde prevalece una sensación de riesgo, de miedo y de pérdida. De este modo, las prácticas violentas responden a una suerte de indignación moral que reclama por el restablecimiento de los códigos que se siente que están rotos. En este sentido, los blogs operan como espacios donde se plasman tensiones y se desarrollan conflictos en vistas a la restauración de esos valores y a la eliminación de quienes los ponen en 
peligro; se delimita un "ellos" como figura del peligro, que varía según el hablante, y se fortalece la construcción de un "nosotros" y se materializan discursos colectivos que reclaman justicia e igualdad con sentidos contrapuestos según cada caso. En estos "dos bandos", el reclamo a las figuras de autoridad (el Estado, los moderadores, los medios, entre otros) se articulan con modalidades de la violencia que buscan excluir a quien se representa como diferente. Si bien estas prácticas coinciden en muchos puntos con las características de los linchamientos o las acciones colectivas violentas, como la espontaneidad, el seudo-anonimato de sus perpetradores y la existencia de un objetivo en común, no podemos afirmar que son análogas: los intercambios violentos online no son unidireccionales y no habría una sola víctima. Por otro lado, no existe la posibilidad de agredir físicamente a los "otros", aunque, es necesario indicarlo, no por eso las consecuencias de las agresiones verbales son menos letales. Asimismo, las modalidades de las violencias en los casos analizados sí buscan acabar con la presencia de ciertos sujetos en los entornos virtuales: por un lado, los agravios pueden disuadir a los usuarios de seguir participando; por el otro, las personas LGBTIQ y sus aliados, y las personas cisheterosexuales, reclaman la eliminación de sus participaciones y el bloqueo de sus usuarios, En respuesta a ello, se argumenta que las personas LGBTIQ son como un ghetto, mientras que se dice que sus atacantes son trolls o comentaristas organizados a los que se les paga para agredir. ${ }^{59}$

En términos analíticos y descriptivos, estas prácticas se asemejan a las de trolling y flaming (ver Moor, 2007; Herring et al, 2002). Estos conceptos, hoy utilizados casi como sinónimos, remiten a aquellos comentarios problemáticos a través de los cuales los usuarios buscan violentar a otros a través del insulto y la ofensa. Según Alice Marwick y Rebecca Lewis (2017), ellos provienen de subculturas diversas, que amalgaman a defensores de los derechos de los hombres, a la extrema-derecha, a los nacionalistas blancos, a anti-feministas, a activistas contra la inmigración y a los trolls. Ellos utilizan un lenguaje ofensivo, diseminan discursos de odio y buscan desacreditar y humillar a individuos o grupos específicos a través del empleo de las herramientas participativas de la web con el propósito de influir en las opiniones y en las agendas mediáticas. ${ }^{60}$ También buscan capturar la atención de los usuarios usando redes sociales

\footnotetext{
${ }^{59} \mathrm{Si}$ bien esto escapa a los fines de esta investigación, los datos compilados en la serie de comentarios eliminados de BP, donde la mayoría de los textos provenía de dos direcciones de IP, podría arrojar ciertas hipótesis sobre las sospechas de ciertos usuarios de que hay trolls u "odiadores seriales" en los blogs.

${ }^{60}$ Un estudio local profundiza sobre el rol de los influenciadores de opinión en Twitter en relación con la noticia de los recortes presupuestarios en CONICET en 2016. Allí se conjetura si los usuarios que
} 
y dirigiéndose a los periodistas y a los bloggers que tienen muchos seguidores con el fin de amplificar el alcance de sus discursos y aumentar su visibilidad, favorecidos por un contexto en el que hubo un auge de los ideales reaccionarios de la extrema derecha en paralelo con una pérdida de credibilidad de los medios de comunicación tradicionales y de las instituciones estatales y una sensación de falta de control sobre el orden social, religioso y político. Y como vimos, estas características están presentes en los comentarios de quienes vulneran los derechos de las personas LGBTIQ y que en respuesta reciben la denuncia de que son trolls y es por ello que se solicita la moderación de sus textos.

En definitiva, Internet se prefigura como el espacio ideal para agredir a las personas por el motivo que sea; nada más útil en este sentido que aludir a la idea de shitstorm que acuña Byung-Chul Han (2014), quien entiende que la comunicación anónima, desprovista de nombre, deviene en la indiscreción y en la falta de respeto ya que escapa a todo tipo de control. ${ }^{61}$ Sin embargo, creemos que la web puede ser usada con otros fines. Por lo pronto, acabamos de ver que en BP y Tx se resiste a discursos normalizantes de la diversidad sexo-genérica y se abren espacios de fuga, tal como muestran otras investigaciones (p. ej. GLSEN, 2013; Green et al, 2015). En consecuencia, los contenidos que se publiquen en el espacio público digital pueden operar como vectores de cambio, de emancipación y agenciamiento, cuando no constituyen actos violentos y discriminatorios. Por esta razón, es tan ingenuo demonizar a Internet como pensar que es un lugar libre de conflicto. Y lo que vimos hasta ahora en esta investigación es que Internet está lejos de ser un espacio inclusivo a pesar de que esta tormenta de comentarios hostiles sí está sujeta a algunas constricciones: tanto en BP como en Tx, la participación de los comentaristas está regulada por la figura del moderador, quien puede tener distintas atribuciones y funciones según las características

retwittean comentarios a favor del ajuste y del desprestigio de la investigación social son bots o si son sujetos reales que hacen publicaciones durante su jornada laboral. Para más, ver: GONZÁLEZ, P. A. (27 de diciembre de 2016) "Jugada preparada", El gato y la caja. Disponible en https://elgatoylacaja.com.ar/jugada-preparada/ [Consultado el 1 de enero de 2017]. Días antes, algunos medios periodísticos habían publicado información sobre las "peores" investigaciones en CONICET, como puede leerse aquí: S/A (21 de diciembre de 2016) "Las 20 peores 'investigaciones científicas' del Conicet, La Internet Online. Disponible en https://www.lainternetonline.com/ultimo-momento/las-20peores-investigaciones-cientificas-del-conicet/ [Consultado el 1 de enero de 2017]. Dichas investigaciones pertenecían a las Ciencias Sociales y se vinculaban con los culturales y los estudios de géneros y sexualidades; más aún, sobre un investigador se publicaron "fotos hot" que extrajeron de su perfil de Facebook.

61 Aquí debemos agradecer la contribución del Dr. Mario Pecheny por sus recomendaciones bibliográficas y sus reflexiones sobre este asunto. 
de cada medio y según las decisiones y los objetivos de sus responsables. Nos explayamos sobre esto en los capítulos que siguen. 


\section{4. "En nombre de la discriminación se discrimina": los editoriales}

Hasta ahora en esta investigación hemos visto que las que las hegemonías culturales y las jerarquías sexuales y de género se traspolan y se resignifican en la web: los usos de las tecnologías digitales pueden basarse en discursos homobilesbotransfóbicos y perpetuar la opresión contra las personas LGBTIQ o bien pueden hacer circular sentidos "otros" que los cuestionen, como en los comentarios de BP y Tx. Ahora bien, los blogs forman parte de tramas institucionales más amplias y pertenecen a dos medios, La Nación y Clarín, que editorializan sobre los sujetos queer que les competen a Dema y Bimbi. Por esto, aquí analizaremos cómo se representa a las personas LGBTIQ en seis editoriales publicados en sus versiones digitales entre 2012 y 2015.

\subsubsection{Editoriales de La Nación}

Los tres editoriales de La Nación, extraídos de la sección “Opinión”, abordaron diferentes temas y con distintos propósitos:

1. En "La Corte de los EE.UU. y el matrimonio igualitario" (14/07/2013) el medio se expresa a favor de reservar la institución del matrimonio para las parejas heterosexuales y en contra del reconocimiento igualitario de los matrimonios entre personas del mismo sexo.

2. En "Uganda: la persecución a los homosexuales" (03/03/2014) se habla en defensa de los derechos de gays y lesbianas y en contra de las leyes que buscan reprimir y penalizar la homosexualidad.

3. En "Absurdo cupo para travestis y transexuales" (01/11/2015) se argumenta en contra de la modificación de la ley que reserva un porcentaje de cargos públicos para las personas trans.

Todos tienen un título y una bajada pero ninguno tiene firma. En ninguno de ellos se emplean imágenes, en uno solo hay un hipervínculo y en ninguno se destacan palabras con negrita. Solo se usan bastardillas en una ocasión para palabras en lenguas extranjeras. Vemos que en líneas generales los textos siguen una estructura argumental prototípica: hay una hipótesis central, se muestran argumentos para reforzarla y finalmente hay una conclusión donde se retoma la tesis y se busca la adhesión del lector. 
Para ello se sirven de distintas estrategias y recursos discursivos, como citas de autoridad, contra-argumentos, preguntas retóricas y ejemplos.

Para empezar con el análisis, tomaremos el primer editorial de la lista, "La Corte de los EE.UU. y el matrimonio igualitario" (14/07/2013). En este texto breve se habla sobre los primeros avances legislativos en materia de reconocimiento de los derechos de la población LGBTIQ. El texto indica que la Corte estadounidense declaró inconstitucional una "ley de defensa del matrimonio" de 1996 que prohibía el matrimonio igualitario, aunque aclara que la decisión estuvo dividida: tuvo cinco votos a favor y cuatro en contra. El medio indica que:

El tribunal no se pronunció acerca de la existencia del derecho a contraer matrimonio entre personas del mismo sexo. El fallo declaró inconstitucional una norma de 1996 llamada "ley de defensa del matrimonio", en cuanto impide que personas del mismo sexo casadas en aquellos estados que lo permiten puedan recibir los mismos beneficios en materia de salud, impuestos y seguridad social que las parejas heterosexuales. Según el juez Kennedy, esa discriminación legal viola la noción de igualdad ante la ley.

"El tribunal no se pronunció acerca de la existencia del derecho a contraer matrimonio entre personas del mismo sexo". Es decir, según el diario, no se emite opinión sobre matrimonio como un derecho que pueda abarcar a las personas LGBTIQ sino que se dice que la Corte buscaba igualar los derechos de las uniones conformadas por parejas del mismo sexo solo en esos estados donde dichas uniones estaban permitidas. Caso contrario, se los estaría discriminando. Pero La Nación no está de acuerdo con los resultados de esta votación: por eso, introduce otro discurso referido y recupera la voz del juez Antonin Scalia, quien votó en contra ya que quería preservar la figura tradicional de matrimonio, postura similar a la del medio. Este juez dijo: "Al declarar formalmente que cualquiera que se oponga al matrimonio entre personas del mismo sexo es un enemigo de la decencia humana confiere armas a quienes cuestionen las leyes estatales que restringen la definición de matrimonio a su definición tradicional”.

Si bien este editorial se refiere al caso de Estados Unidos, en el último párrafo se expresa sobre el matrimonio entre personas del mismo sexo en Argentina. Su conclusión es la siguiente: 
Desde esta columna no podemos dejar de señalar que una cosa es no discriminar entre los efectos de estas uniones en jurisdicciones que las permiten y, otra, sostener que ambas están incluidas en la definición de matrimonio. Lo cierto es que todavía, en los Estados Unidos y entre nosotros, hay quienes reservamos la institución matrimonial para las uniones heterosexuales, más allá de la disposición a igualar los efectos en materia de seguridad social, fiscal o patrimonial de los matrimonios con los de las uniones entre personas de un mismo sexo.

La conclusión, intensificada por el uso de "no podemos dejar de señalar" y con el uso de la primera persona en plural, refuerza la idea de que la institución del matrimonio debe reservarse para las uniones heterosexuales. Según el medio, como aclara, excluir a los homosexuales de la definición del matrimonio no implica tener una voluntad discriminatoria. Se combina el uso de los topoi de humanitarismo, de derecho y de definición; de este modo, se construye una idea de un "nosotros" inclusivo que abarca a argentinos que no discriminan, que son igualitarios pero que se rehúsan a incluir a las parejas del mismo sexo en la institución matrimonial dado que lo entran en la definición del término. Se habla en nombre de todo el medio y se marca discursivamente una proximidad ideológica con personas en Argentina y en Estados Unidos con posturas similares, incluyendo una persona de autoridad, el juez Scalia. No se habla de homosexuales sino de parejas de un mismo sexo y se dice implícitamente que estas parejas no son iguales a las heterosexuales; se evita realizar un pronunciamiento a favor de la igualación en materia de seguridad social, fiscal o patrimonial. Y, finalmente, se refuerza el binomio hetero/homo invisibilizando otras alteridades y se perpetúa el goce desigual de los derechos de un "otro" no heterosexual.

El editorial "Uganda: la persecución a los homosexuales" (03/03/2014) tampoco habla sobre Argentina pero sí da cuenta de la postura editorial de La Nación en torno a la discriminación y violencia hacia personas LGBTIQ. Allí se critica la aprobación de una ley que criminaliza la homosexualidad en ese país y que "amplía la represión contra gays y lesbianas". Se contrapone la postura del gobierno ugandés con las de entidades internacionales y gobiernos extranjeros que "desde hace tiempo se han levantado contra esta equivocada concepción concebida contra miles de personas". A continuación se mencionan países con normativas similares a las de Uganda que criminalizan la homosexualidad, las relaciones homosexuales y las demostraciones públicas de afecto entre estos. Sus castigos varían y pueden incluir prisión o pena de muerte. Más aún, el 
medio sostiene que "la aprobación de la ley ugandesa ha puesto a miles de personas sobre todo a los activistas de los movimientos de gays y lesbianas- en serio peligro, incluso de muerte". Y critica a los diarios locales que han difundido listas con nombres de homosexuales, que, como dice, "desató afortunadamente una ola de rechazos en el país". Los adverbios de cantidad y de modo se emplean como recursos estratégicos para aumentar la fuerza ilocutiva de las aseveraciones esgrimidas en contra de las acciones del gobierno y los medios de Uganda. Prosigue:

Las razones que justificarían estas persecuciones de por vida, y Uganda no es la única en esgrimirlas, es que un grupo de científicos le explicó a [Yoweri] Museveni [presidente de Uganda] que la homosexualidad "no era una conducta genética" y que es una "elección llevada a cabo por individuos que pueden intentar influir en otras personas".

"Un grupo de científicos", cuyos nombres o instituciones de pertenencia permanecen ocultos, indica que las personas eligen ser homosexuales y que pueden influir a otras; el resto del escrito no contradice esta afirmación.

Luego, en el último párrafo, recupera la voz del premio Nobel de la Paz sudafricano Desmond Tutu, quien compara esta ley con el apartheid y con las persecuciones nazis. El texto finaliza con las siguientes afirmaciones:

Una vez más, los derechos humanos de una parte de la sociedad mundial son conculcados. Por eso es necesario que desde organizaciones internacionales como las Naciones Unidas se sigan denunciando estas situaciones repudiables que institucionalizan la discriminación y alientan el acoso y la violencia contra las personas.

Aquí el diario emplea los topoi del humanitarismo y del derecho para mostrarse en contra de la discriminación de las personas LGBTIQ. Intensifica su postura con el uso de conectores causales y oraciones impersonales para oponerse a aquellas situaciones que adjetiva como "repudiables" dado que "institucionalizan la discriminación y alientan el acoso y la violencia contra las personas". A su vez, atribuye a las organizaciones internacionales la responsabilidad de denunciar y repudiar leyes como la de Uganda, aunque no da cuenta de acciones colectivas de protesta nacionales e internacionales en rechazo de esa ley. Por último, vemos que con el uso de modalizadores como "equivocada concepción" y "situaciones repudiables" y con 
intensificadores como "es necesario que [se sigan denunciando...]", el diario busca mostrar que su postura es contraria a la vulneración de las personas LGBTIQ. No obstante, en el afán por rechazar por igual todo tipo de discriminación y violencia en su contra, el medio falla en reconocer su lugar como actor o promotor de las condiciones que hacen posible la discriminación que afecta a este colectivo y tampoco problematiza sobre las condiciones materiales y simbólicas diferenciales que afectan al sector en Uganda ni en el país.

El último editorial se titula "Absurdo cupo para travestis y transexuales" (01/11/2015) y tiene una bajada que dice: "Disponer mediante una ley que una persona tenga derecho a acceder a un cargo por la elección sexual que realiza no es protegerla, sino discriminarla”. Se publicó un mes después de la aprobación de la ley provincial de cupo laboral trans $\mathrm{N}^{\circ} 14.783$ de la provincia de Buenos Aires. ${ }^{62}$ Aquí el editorial argumenta en contra de este "absurdo cupo" y en contra de esta "controvertida ley que obliga a todos los organismos del Estado provincial a incorporar trabajadores travestis, transexuales y transgénero hasta que al menos alcancen el 1 por ciento del total de la plantilla”. Reproduce un fragmento de la ley para explicar su alcance y su objetivo, que consiste en "generar igualdad de oportunidades ante las dificultades que tienen estas personas para lograr una inserción laboral y trabajo digno". A continuación calcula que se deberá cubrir un total de 4.500 puestos laborales con personas trans una vez que la ley se reglamente.

Acto seguido, expresa que:

Representantes de asociaciones civiles que las agrupan celebraron la aprobación de la norma y recalcaron la difícil situación laboral de estos grupos, que con frecuencia -afirman las asociaciones que los nuclean? (sic) no encuentran otro medio fuera de la prostitución para mantenerse económicamente.

Paradójicamente, ese criterio denigra a quienes han hecho su elección de género pues, de ningún modo, son inferiores a cualquier persona heterosexual. Afirmar lo contrario es discriminarlos.

\footnotetext{
${ }^{62}$ Un año más tarde, se aprobó la resolución 164/2016 que establece un cupo laboral de 2\% para personas trans e intersexuales que muestren idoneidad para cargos en la Defensoría del Público de Servicios de Comunicación Audiovisual. Esta norma es posterior a la ordenanza 9.543/2016 de la Municipalidad de Rosario, provincia de Santa Fe, que establece condiciones de promoción e inclusión laboral de personas trans.
} 
Aquí se habla de asociaciones civiles defienden la ley pero no se especifican sus nombres; asimismo, se realiza una cita indirecta a fin de recuperar sus argumentos a favor de la ley, diciendo que la prostitución (y no el trabajo sexual) es el medio al que acuden con frecuencia las personas trans para mantenerse económicamente. No disocia entre las múltiples identidades, corporalidades y subjetividades trans así como tampoco presenta estadísticas ni cifras ni testimonios de las personas que presupone que se prostituyen y/o que son trabajadora/es sexuales ni reflexiona sobre las condiciones que históricamente relegaron a las personas trans a trabajar por fuera de los márgenes laborales formales. El texto sigue con la introducción de un conector de contraste ("paradójicamente") para aseverar que las personas trans "han hecho su elección de género" y que "de ningún modo son inferiores a cualquier persona heterosexuales", aunque omite mencionar si se cree que son iguales a estos. Como expresa inmediatamente, decir que son inferiores sería discriminatorio. En este sentido, para el diario La Nación, la ley es discriminatoria y va en contra del criterio de igualdad. El topos de humanitarismo se emplea como estrategia argumentativa en rechazo de una norma que justamente busca promover la igualdad de las personas.

El editorial sigue así:

La norma nace viciada en su origen, ya que precisamente viola el principio de igualdad ante la ley, que es precisamente el esgrimido para evitar normas discriminatorias, tal como lo reclaman las campañas realizadas por las organizaciones de gays, lesbianas y transgénero, en su lucha por la igualdad.

El vicio en este caso es claro y consiste en que la ley aprobada consagra precisamente un privilegio que no debiera consagrar.

A través del uso construcciones semánticas metafóricas, se atribuyen acciones y propiedades negativas a una ley que de ese modo pasa a estar ligada a los verbos “discriminar" (a quienes quedan fuera), "denigrar", "violar" (el principio de igualdad ante la ley, la Constitución) y "privilegiar" (a las personas trans, discriminación positiva, principio de no igualdad), sin omitir el uso del adjetivo y luego sustantivo "viciada" y "vicio", que se dice que es "claro", como modo de aumentar la fuerza argumentativa del texto.

En este editorial, al igual que en el anterior, nos encontramos con una postura que se expresa crítica a todo tipo de discriminación negativa y positiva dirigida a lesbianas, gays y personas trans. Se sostiene que: 
La elección de género es un derecho individual, personalísimo, que a la vez no justifica discriminaciones, no puede amparar privilegios que violen el derecho de igualdad ante la ley protegido constitucionalmente.

Actualmente, los homosexuales no están discriminados legalmente, tienen derecho a la igualdad constitucional, pero leyes como las que nos ocupan, discriminan a los demás ciudadanos con posibilidades a aspirar a esos cargos, les reducen el porcentaje de oportunidades para acceder a ellos.

Una vez más el texto nombra a la identidad de género como si fuese una elección; le reconoce su estatuto de derecho y se expresa que como tal no debe ser objeto de discriminación dado que "no puede amparar privilegios que violen el derecho de igualdad ante la ley protegido constitucionalmente" (topos de humanitarismo). La reiteración de la frase "violar el derecho de igualdad" contribuye a reforzar una representación peyorativa de la ley y una representación negativa de las personas trans, que parecen amenazar el acceso a cargos públicos por parte de personas no trans. En el párrafo siguiente se dice que los homosexuales (que no son las personas trans, aunque para el texto sí) no están discriminados "legalmente" ya que son iguales a todos ante la ley (topos de legalidad y derechos). No permite entrever si el medio reconoce la existencia de modos de discriminación simbólica y que se traducen en exclusiones en los planos económicos, sociales, sanitarios, políticos, laborales y educativos.

Para apoyar nuevamente la hipótesis de que esta ley discrimina positivamente a las personas trans y negativamente a quienes no lo son ("los demás ciudadanos con posibilidades a aspirar a esos cargos”), se dice que este cupo laboral les reduce el acceso al resto (topos de peligro y amenaza). Después, se afirma que el criterio de selección para los cargos públicos debería ser la idoneidad y no la elección de género:

El requisito para la función pública es únicamente la idoneidad, como reza el artículo 16 de la Constitución Nacional: “Todos sus habitantes (de la Nación Argentina) son iguales ante la ley, y admisibles en los empleos sin otra condición que la idoneidad". Precisamente, ésa es la vara que debe medir la admisión de las personas a los cargos, y no su elección de género.

En estas líneas observamos que se extrae un fragmento de la Constitución Nacional, como palabra de autoridad de la que ya se había recuperado la noción de igualdad legal. Asimismo, se intensifica el posicionamiento del autor a través del uso del adverbio de modo "precisamente" para respaldar su afirmación de que la idoneidad debe ser el 
criterio de admisión y contratación; con el verbo "debe" también se modaliza el discurso como forma de lograr la adhesión del lector. Nótese la ausencia de adverbios de duda o de probabilidad.

Más adelante, acudiendo a los topoi de la historia y de analogía, el medio compara la ley de cupo laboral trans con la ley de cupo femenino:

[La ley de cupo femenino] fue muy criticada por las propias feministas por entender que su aplicación determinaba una discriminación al revés. Entendían que las colocaba en una categoría protegible, que las minusvaloraba el hecho de que sólo con un cupo garantizado pudieran acceder a los cargos elegibles cuando, como mujeres, estaban igualadas para competir con todos los candidatos masculinos por la totalidad de los puestos en las nóminas electorales.

Se dice que la ley de 1991 fue muy criticada, o al menos sus adverbios de cantidad ayudan a intensificar la fuerza argumentativa de que ello fue así. A su vez, se sostiene que fueron las "propias feministas" quienes dijeron que la ley implicaba una "discriminación al revés". Pero no se incluyen nombres ni se identifica a estas mujeres sino que se introduce una cita indirecta para volver a defender el criterio de igualdad y para rechazar leyes como las nombradas.

Acto seguido, se reitera la defensa del principio de no discriminación y, de modo solapado, el de igualdad de las personas homosexuales (quienes “eligen” su género) en las siguientes oraciones: "Una persona homosexual no debe tener derecho a un cargo por su elección de género. Sí tiene todo el derecho a no ser discriminada por esa elección, pudiendo competir con cualquiera ante cualquier nombramiento". Para rechazar el cupo laboral y los supuestos privilegios que otorga este derecho, se dice que una persona homosexual puede competir con cualquiera (un "otro" no homosexual, no trans) en los cargos de entidades de gestión estatal. De nuevo, omite realizar un análisis sobre las condiciones de desigualación que existen en el mercado laboral y no indaga ni problematiza sobre los casos de despidos por discriminación.

En el último argumento que se expone para refutar la ley se dice que en la práctica "muchas veces" estas normas son inviables; el ejemplo que se da para graficarlo es sobre la situación laboral de las personas con discapacidad:

Al margen de tales consideraciones, es necesario recordar que muchas veces esta clase de normas se tornan impracticables por diferentes motivos. Desde 
hace mucho tiempo, existen en el orden nacional y en un buen número de provincias y municipios leyes que obligan a las administraciones públicas, entre ellas, la bonaerense, a incluir el 3\% de personas con capacidades diferentes en la planta de trabajadores estatales. Sin embargo, en la mayoría de los organismos oficiales, este cupo dista de ser cumplido. No se protege a quien necesita protección y, en cambio, se privilegia a quien no la necesita.

La persona homosexual no padece una discapacidad ni mucho menos: la historia lo demuestra suficientemente. (El destacado es nuestro)

Una vez más aparece el uso de oraciones impersonales de necesidad, junto con un adverbio de cantidad ambiguo ("muchas veces" no dice cuántas veces ni con qué frecuencia), sostiene que leyes como esta son impracticables. Compara la ley de cupo laboral trans con la del cupo para discapacitados, sin dar el número de ley y otorgando una cifra equivocada: el número correcto no debe ser inferior al 4\%. En las frases que destacamos, se dice que hay un grupo de personas que necesita protección (los discapacitados), a diferencia de un grupo que no la necesita y al que se lo está privilegiando: "la persona homosexual no padece una discapacidad ni mucho menos: la historia lo demuestra suficientemente". Tras comparar una ley sobre las personas con discapacidad con otra referida a las personas trans ("homosexuales" para La Nación), ahora se los diferencia en tanto las primeras son discapacitadas $\rightarrow$ necesitan protección, y las segundas no padecen una discapacidad $\rightarrow$ no necesitan protección. Parece que "la historia" muestra "suficientemente" lo que el diario falla en explicitar, que es a qué procesos históricos se refiere y qué es específicamente lo que ellos demuestran. El adverbio de modo que pretende aumentar la fuerza ilocucionaria del discurso se ve contrarrestado por el exceso de generalización y por la falta de precisión en el texto. Más aún, la combinación del topos de historia y del topos de abuso lleva a reforzar la idea de que la ley privilegia a un grupo a costas de otro.

Como conclusión, el medio nos dice que:

El Estado debería garantizar la integración y la no discriminación mediante otros mecanismos serios de selección, dejando que el acceso a los puestos laborales en el sector público quede librado exclusivamente a las condiciones de idoneidad para cada cargo, evaluadas a través de procedimientos imparciales, como los concursos por antecedentes, independientemente del género y de la elección sexual de cada postulante. 
Aquí, en modo condicional, se atribuye al Estado la responsabilidad de garantizar que se integre y no se discrimine a las personas mediante "otros mecanismos serios de selección", pero no el género y la elección sexual porque no son criterios serios ni imparciales como sí lo es la idoneidad para un puesto.

Entonces, la ley provincial de cupo laboral trans es discriminatoria porque privilegia a unos y lo hace a expensas de otros: a todas las personas afectadas (no trans, no homosexuales) se les quitan posibilidades de acceder a un cargo público. Pero además la ley es impracticable, como en el caso de las pautas laborales referidas a las personas discapacitadas, recordando que ese tipo de normas son para proteger a personas que están siendo desprotegidas por incumplimiento de la ley y se está protegiendo de por más a alguien que no necesita esa protección. Más aún, como en el caso de la ley de cupo femenino, muy criticada por las feministas, y retomando una frase anterior, "una persona homosexual no debe tener derecho a un cargo por su elección de género". Es por todo ello que La Nación se opone a la ley y a todo tipo de discriminación. Pero el medio obtura la comprensión sobre las tramas históricas que oprimen a este sector al no profundizar sobre todos los debates que hicieron posible la aprobación de la ley y al no ahondar sobre los exterminios y las exclusiones materiales y simbólicas que de modo sistemático afectan a las personas LGBTIQ.

En suma, La Nación en sus editoriales alude a las personas LGBTIQ desde una mirada igualitarista en pos de la no discriminación y del respeto de sus derechos. En los textos analizados, predomina el uso de los topoi de humanitarismo y de derechos, pero observamos que se hacen dos usos contrarios sobre ellos: por un lado, se habla de la igualdad ante la ley de las personas LGBTIQ para defender sus derechos y velar por su integridad, pero, por el otro, se emplean estos topoi para argumentar en contra de las medidas judiciales y propuestas de ley que protegían y garantizaban sus derechos al matrimonio y al empleo. Vemos que este tipo de igualación a medias se ve reforzada por la representación de las personas LGBTIQ como sujetos que se verían beneficiados o privilegiados con dichas normas; es decir, al igual que en los comentarios discriminatorios sobre las personas LGBTIQ de BP, se aduce que las leyes que se ocupen de este sector no son justas y no son igualitarias, porque en todo caso constituyen un privilegio y una forma de discriminación positiva que margina al resto de la sociedad. Se citan voces autorizadas para sostener esta perspectiva, pero no se recuperan las opiniones de las personas que escapan de la cisheteronormatividad. Solo se realiza una cita indirecta sobre el reclamo de organizaciones LGBTIQ, pero se habla 
sobre ellas de modo ambiguo dado que no se precisa a cuál o cuáles organizaciones se refiere.

Por lo tanto, en estos tres editoriales se representa a las personas LGBTIQ como seres que atropellan los derechos de sus pares cisheterosexuales en la medida de que avanzan sobre ellos. Luego, se refiere al principio de igualdad ante la ley y a la idea de igualdad de condiciones en el mercado laboral, como en los comentarios analizados, con el propósito de reiterar la idea de que los sujetos con orientaciones sexoafectivas y expresiones e identidades de género no normativas ya son iguales y ya tienen iguales derechos; por lo tanto, cualquier ley que se ocupe de este grupo constituye un absurdo privilegio que discrimina al resto. Además, no son discapacitados y si quieren trabajar deben demostrar su idoneidad para el puesto y no esperar protecciones por parte del Estado. Pero éste debe garantizar que a estas personas no se las violente ni se las discrimine, si bien para el medio no es discriminatorio negarles el derecho a contraer matrimonio. Estos argumentos y las representaciones sobre las personas LGBTIQ guardan similitud con los que vimos en algunos comentarios del corpus de BP. De hecho, identificamos ciertas continuidades entre los comentarios publicados en BP y la línea editorial de La Nación entre 2012 y 2015 debido a que en ambos espacios predomina una postura heteronormativa respecto al matrimonio y una perspectiva ambigua de respeto por los derechos de todos, sin reconocer el propio lugar en la propagación de las asimetrías del orden sexo-genérico ni su complicidad en dejar intacta la aparentemente incuestionable matriz de justificación cisheteropatriarcal que excluye a las personas LGBTIQ $\mathrm{y}$, especialmente, a aquellas que tienen condiciones socioeconómicas desfavorables y que tienen dificultades para acceder a un derecho tan elemental como es el derecho a un trabajo digno.

\subsubsection{Editoriales de Clarín}

Los tres escritos de Clarín se extraen de las secciones de "Opinión" y "Política"; todos tienen la etiqueta "Del editor al lector" y solo dos tienen autor. Sus títulos y sus temas son:

1. "En lo cotidiano está la vida" (30/07/2013) presenta la opinión del Papa Francisco sobre distintos temas, incluyendo las relaciones homosexuales. 
2. En "Cambiar de sexo a los 6 años" (10/10/2013), el editor critica el reconocimiento estatal de la identidad de género de Lulú, una niña trans.

3. En "Travestis, cometas, Cristina y un juez" (27/11/2014), el medio se expresa sobre diferentes asuntos. El que nos compete se relaciona con los proyectos para otorgar un subsidio a las personas trans y con la postura crítica de Clarín. Se publicó el mismo día que la entrada del blog de Bimbi sobre dicho subsidio.

En solo uno de estos editoriales hay una bajada y una imagen con epígrafe, que no guarda relación con temas de diversidad sexo-genérica. En ninguno se utilizan hipervínculos dentro del cuerpo del texto. Los destacados aparecen en negrita, recurso que se emplea en todos los textos de Clarín para enfatizar los núcleos argumentativos y el posicionamiento del medio.

El primer editorial es "En lo cotidiano está la vida" (30/07/2013) y lo firma Ricardo Roa. Allí se habla sobre una conferencia papal y sobre la postura de Jorge Bergoglio con respecto a varios "terrenos espinosos", como la homosexualidad. Allí se citan las palabras textuales del ex cardenal, que sobre la cuestión dijo: "si una persona es gay pero busca al Señor con buena voluntad, ¿por qué debería yo juzgarlo?’. El escrito continúa así:

Francisco no juzga la vida privada, que es privada. Eso lo deja reservado a Dios y a la conciencia de cada uno aunque las relaciones homosexuales no son aprobadas por la Iglesia, como el sexo fuera del matrimonio.

\section{Es como decirles a los fieles que su vida íntima les pertenece sólo a ellos.}

Que el Papa no condene la homosexualidad primero es una sorpresa y después, una fuerte señal de renovación que levantará polémicas dentro del Vaticano. A más de un conservador se le habrán puesto los pelos de punta. (Destacado en el original)

Así se nombra a las relaciones homosexuales como propias de lo privado, de la vida íntima. Bergoglio no las condena ya que ello le corresponde juzgarlo a Dios y a cada uno en su conciencia. Luego Roa nos recuerda la posición eclesiástica sobre el tema, que no aprueba estos vínculos, del mismo modo que desaprueba el sexo extramatrimonial; omite decirlo pero, para esta religión, ambos son pecados (topoi de comparación y definición). Luego, el destacado en negrita enfatiza y sintetiza la postura papal, contraria a la de sus pares del Vaticano que sí condenan la homosexualidad. Para el autor, el Papa no avala estos vínculos pero tampoco los condena. Según él, esto es 
una "sorpresa", una "fuerte señal de renovación", pero también algo que "levantará polémicas dentro del Vaticano" y que "le habrán puesto los pelos de punta" a más de un conservador. Resalta no solo la oración que está marcada con un estilo tipográfico distinto sino que acude al empleo de modalizadores como "fuerte señal", "sorpresa", "polémica" y la frase figurativa "pelos de punta" para enfatizar la "renovación" que representa el enunciado papal. Y de paso nos recuerda que el resto del séquito de Bergoglio está conformado por personas conservadoras, que guardan una postura que, deducimos, es más cercana a la de Roa. Sin embargo, parecen coincidir en un punto: la homosexualidad es algo del ámbito privado, más o menos aceptable siempre y cuando sea algo íntimo y no algo visible o público.

En los párrafos posteriores se avanza sobre temas que no son de interés para los fines prácticos de la presente investigación. Por ejemplo, se expresa que Bergoglio cuestionó que haya curas que se quieran casar, que se ordenen monjas o que comulguen las personas divorciadas que se volvieron a casar. Pero luego se recuperan citas de él como "en lo cotidiano está la vida" (destacado en el original) y "Jesús nos ofrece algo más importante que la Copa del Mundo" para que Roa se pueda explayar sobre temas vinculados a la coyuntura argentina de ese entonces, como Fútbol para Todos, los fondos en el sistema educativo y las acciones de la ex Presidenta Cristina Fernández. Dice que Francisco "se muestra precisamente como lo que es, un hombre" y que "dio muestras de habilidad y coraje políticos" (destacado en el original). Se busca presentar a una figura eclesiástica que "tiene en claro sus objetivos" y que quiere que la Iglesia pueda recuperar fieles; su misión es ser un conductor, "purgar a la Iglesia de los escándalos financieros y de pedofilia" y luchar contra la pobreza y la corrupción y la pedofilia. No vuelve a versar sobre la homosexualidad.

El segundo editorial es “Cambiar de sexo a los 6 años" (10/10/2013) y también lo firma Roa: allí habla sobre el caso de Lulú, una mujer transexual de seis años que obtuvo el cambio de DNI para adecuarlo a su identidad de género. Así lo explica la madre de Lulú en el libro Yo nena, yo princesa (Mansilla, 2014). Pero Roa nunca utiliza la palabra transexual o transgénero; es más, se refiere a Lulú como una persona que “tiene apenas 6 años” y que "ya no es más un varón sino una niña”. En primer lugar, el autor dice que Lulú antes era un varón pero ahora es una niña, sin respetar su identidad a pesar de lo establecido en la Ley de Identidad de Género en lo que respecta, sobre todo, a las infancias trans. Además subraya el dato biológico y el género asignado al nacer a Lulú, centrando sus dichos en factores externos y ajenos a la voluntad de ella. 
Más aún, se dice que tiene "apenas" seis años, con lo que se busca deslegitimar la autonomía a decidir sobre su identidad y su cuerpo. Luego, dice que "no existen en el mundo antecedentes como este. El Gobierno bonaerense aprobó su cambio de sexo y de identidad sin intervención de la Justicia" (destacado en el original). Con el topoi de responsabilidad y de derecho, culpabiliza al Estado por haber actuado de acuerdo con una estrategia política y en detrimento de los derechos de la menor, si bien subyace una mirada paternalista y proteccionista de los derechos de ella.

En el párrafo que sigue, expresa que:

Gabriela, la madre de Lulú, había argumentado que el cambio fue un reclamo de su hijo que siempre sintió y actuó como una nena. "Yo sólo la acompañé", explicó. También afirmó que la misma niña había elegido el nombre de Lulú "a los 4 años y nos dijo que si no la llamábamos así no nos contestaría". Lulú tiene genitales masculinos pero no por eso debe asumir su masculinidad como si ese fuera el único camino. La cuestión es que ella no ha tomado ninguna decisión porque no está en edad de tomarla: a los seis años no se deciden cosas como éstas. El Estado y sus padres han tomado la decisión por ella. (Destacado en el original)

Mediante la incorporación de discursos referidos provenientes de la madre de Lulú, el diario argumenta que "su hijo" eligió su nombre y siempre sintió y actuó como nena, reduciendo así una cuestión identitaria a una performance o a un sentimiento. Además, se hablan de los genitales de la menor, si bien se reconoce que por tener "genitales masculinos [...] no por eso debe asumir su masculinidad como si ese fuera el único camino”. Es decir que por tener ciertos genitales que según Clarín son masculinos, es poseedora de una masculinidad que puede asumir o no como tal, siendo que hay otros caminos posibles. Pero por otra parte se dice que Lulú decidió qué nombre usar, aunque en el párrafo que sigue se deslegitima su decisión por tener seis años y por no estar en edad de tomar decisiones sobre "cosas como éstas". Para Clarín, entonces, "el Estado y sus padres han tomado la decisión por ella". De nuevo, los responsables y los únicos culpables son los adultos.

El texto sigue:

En diciembre pasado, el Registro Provincial de las Personas había rechazado el cambio de DNI [de Lulú] luego de recibir un dictamen de un Tribunal de Morón 
al que había recurrido la familia para iniciar el trámite. Pero las autoridades cambiaron de opinión sin que quedara claro por qué.

Dijeron que habían consultado a especialistas y que "la determinación está amparada en la Ley de Género y además en la Convención Internacional de los Derechos del Niño", que tiene rango constitucional. ¿Los derechos del niño fueron efectivamente respetados? ¿Basta con el pedido de un chico de 6 años para autorizar un cambio de sexo y de identidad? (Destacados en el original)

Fueron los padres quienes presentaron la solicitud de cambio registral de Lulú, que inicialmente les fue denegado. Pero Clarín no entiende por qué luego le permitieron avanzar con el trámite a pesar de que atropella los derechos de la infante y por eso recupera la voz de las autoridades que habían dialogado con especialistas y que encontraron respaldo en la Ley de Identidad de Género y en la Convención Internacional de los Derechos del Niño. El empleo de preguntas retóricas dispara la reflexión acerca de si efectivamente se respetaron los derechos de "el niño", de nuevo en masculino; y si es suficiente el pedido de "un chico de 6 años" (otra vez, en masculino, sin respetar la identidad de género de Lulú) para cambiar de sexo y de identidad. El autor confunde entonces no solo la constitucionalidad de ciertas normas sino también los términos "sexo", "género" e "identidad".

Roa asevera que:

El tema es muy delicado. Tiene que ver con la manera en que se identifica y clasifica a las personas institucionalmente. Y lo más relevante, que es algo traumático y doloroso para el niño y su familia así se lo presente con otro ropaje o, peor aún, que el jefe de Gabinete de Scioli lo explote y convierta una cosa tan íntima en un acto de campaña política.

Mejor que celebrarlo como una batalla ganada contra el oscurantismo y los prejuicios sería mirar todo con prudencia y con cuidado para velar por la integridad de quien está atravesando tensiones y conflictos con su propio cuerpo. (Destacados en el original)

Este texto pretende velar por los derechos del "niño". Se habla de los procesos que atraviesa Lulú como algo íntimo y delicado, como algo que se representa como "traumático y doloroso" para este y su familia, si bien son discursos como estos los que sostienen una matriz de pensamiento cisheteronormativa que puede volver traumáticas y dolorosas las experiencias de cualquier infante (y adulto) trans. Asimismo, se reitera la 
presunción de que todo esto es una estrategia política de Scioli, aunque "se lo presente con otro ropaje". La selección de palabras en esta última cita es llamativa: se recordará que en Tx se aludía a las travestis como hombres que se disfrazaban y se vestían de mujeres para cobrar un subsidio, con palabras similares a las que se emplean para referir a las mentiras o al encubrimiento que se supone que hizo el ex jefe de Gabinete.

El texto sigue así:

Muchas veces y con las mejores intenciones, se trata de resolver el problema apenas se manifiesta como si así quedara allanado el camino hacia un porvenir feliz ¿pero quién puede saberlo?

Cualquier salida tomada a la ligera puede agravar el conflicto en lugar de remediarlo.

Es una situación en la que no hay nada para festejar porque las respuestas son necesariamente parciales e imperfectas. Y que demanda cautela a los padres, a las instituciones y a los medios para resguardar la intimidad. (Destacados en el original)

Ahí deja de hablar sobre las intencionalidades políticas de unos para pasar a hablar del asunto como un "problema" y como un "conflicto" que no se debe tomar a la ligera (sic) y que se debe resolver y remediar. Expresa incertidumbre sobre la posibilidad de que haya un porvenir feliz a través del uso de una pregunta retórica y de otras palabras en negrita para indicar que cualquier solución rápida puede volver más grave algo que para Roa ya lo era. Es que, como dice después, no hay nada de celebratorio en la cuestión y todos, padres, instituciones y medios de comunicación, tienen que preservar la intimidad de Lulú. Es decir, no darle publicidad a lo que es para él un asunto íntimo, si bien el resguardo sobre las experiencias de infancias trans perpetúa la falta de visibilidad y de concientización sobre las mismas, lo que deriva en continuar abordando la temática como si fuese un secreto privado.

Finalmente, concluye que:

Hay que acompañar y velar a las vidas pequeñas apresadas por presiones de este tipo. Y, en vez de celebrar livianamente la entrega de documentos a los padres, proteger, cuidar, respetar y ayudar a crecer a los menores con la mayor contención que se les pueda brindar. 
Sumado a lo dicho anteriormente, atribuye la decisión del cambio registral al gobierno de Scioli y a sus padres, que no velaron por la integridad de Lulú. A través de los topoi de responsabilidad y del derecho, el autor resalta que se debe acompañar y contener a los menores, a esas "vidas pequeñas apresadas por presiones de este tipo". El medio se opone al acto de celebrar la entrega del DNI y dice que hay que "proteger, cuidar, respetar y ayudar a crecer" a los menores y brindarles contención. Se emplean verbos en modo imperativo del deber hacer y utiliza un conector textual adversativo para criticar la postura de los adultos que "livianamente" decidieron por Lulú y celebraron su "cambio de sexo", con un sesgo paternalista que refuerza la noción de infante desprotegido que los adultos deben proteger. Este interés por el cuidado de los niños guarda similitud con los argumentos esgrimidos en Tx (y también en BP) en contra del reconocimiento igualitario del matrimonio y de la adopción homomater u homopaternal.

El último editorial de Clarín se titula "Travestis, cometas, Cristina y un juez"; no tiene autor y su bajada dice: "El país del despropósito es el país en que los propósitos más simples y racionales no pueden cumplirse". Se publicó el 27 de noviembre de 2014, el mismo día que Bimbi publicó la entrada "Hablemos del subsidio para travestis y transexuales" en Tx. En el diario se abordan tres ítems que constituyen "una negación del sentido común" y "una burla al sentido común"; a saber, 1) dos proyectos de ley para subsidiar a las personas trans, 2) una causa de corrupción contra Omar Caballo Suárez, el sindicalista propietario del barco llamado "Cometa", y 3) irregularidades en torno al hotel Hotesur de la en ese entonces Presidenta. El que nos compete es solo el primer tema, relacionado con las personas trans:

Si dos proyectos legislativos prosperan, los travestis cobrarán un subsidio que más que un subsidio será un sueldo mensual. De arranque superará entre el 70 y el $80 \%$ el salario mínimo, vital y móvil vigente desde el 1 de septiembre. Será de $\$ 7.500$ u $\$ 8000$ contra $\$ 4.400$. (Destacado en el original)

En este párrafo se habla de las personas trans como "los travestis", aludiendo en masculino a una porción de mujeres trans y a una pequeña población trans del país. Se sirve del topos de los números para equiparar al subsidio con un sueldo mensual de $\$ 7.500$ u $\$ 8.000$ y se denuncia que será más alto que la jubilación mínima, vital y móvil de $\$ 4.400$, tergiversando la cifra original de los proyectos. ${ }^{63}$ Más aún, se genera una

\footnotetext{
${ }^{63}$ El post de Bimbi se encarga de refutar la idea de los $\$ 8.000$ y de dar detalles sobre los proyectos de ley.
} 
falsa dicotomía que coloca a las personas trans por un lado y a los asalariados y jubilados por el otro y construye adversidades entre ambas partes dado que, como se indica, las primeras ganarían más dinero que las personas que están trabajando o que ya se jubilaron. En esta comparación, se omite mencionar que este subsidio comportaría una reparación histórica y que solo se la destinaría a personas que cumplan con requisitos específicos, como la edad y la residencia en la Capital Federal, como sí explica Bimbi en su post.

A continuación se dice que las impulsoras de estos proyectos son "las diputadas kirchneristas" Diana Conti y María Rachid, quienes "aducen que [el subsidio] es por el menoscabo que los travestis sufren", frase que se destaca en negrita en el editorial. El texto continúa así:

\footnotetext{
Y entre los "derechos constitucionales" que dicen son vulnerados citan: "La igualdad y la no discriminación, la dignidad personal, el trabajo; la seguridad física, la seguridad social; la privacidad; la salud integral; una adecuada calidad de vida y la garantía de acceso a la educación".
}

Primero el discurso referido indirecto y luego el directo se incorporan para expresar qué dicen las diputadas sobre los derechos que son vulnerados y menoscabados de las personas trans y por qué impulsas los proyectos de ley desde los topoi del derecho y del humanitarismo.

Pero se incorporan sus voces para refutarlas dado que, inmediatamente, el diario sentencia:

Millones de personas padecen situaciones similares a las que se les atribuyen a los travestis. Podrían exigir un trato igual, aunque más les valdría no hacerse ilusiones o convertirse en trans. En nombre de la discriminación se discrimina en favor de los travestis. (Destacado en el original)

Tanto antes con la cifra de $\$ 8.000$ o ahora con la cifra exagerada de "millones de personas", se sirve de hipérboles y del topos de los números para disuadir a los lectores de apoyar esta propuesta de ley por lo desigualitaria que es. Esos millones de personas podrían convertirse en trans, como se dice, volviendo a caer sobre la presunción de que la identidad de género es una elección, una forma de tarea de conversión que aparentemente puede ayudar a recibir tratos especiales como con leyes como las que se abordan, que constituyen un tipo de discriminación a favor de "los" travestis. Más aún, 
con el uso de la tipografía en negrita se destaca que una ley como esta es discriminatoria en tanto margina a unos "otros" no trans, si bien el pretexto que da origen a la ley es la lucha contra la discriminación. Estos tres elementos (ser trans como elección; referirse en masculino a las travestis, en nombre de toda la población trans; y hablar de esta propuesta de ley como un beneficio), nos permiten ver que hay cierta continuidad ideológica con varios de los comentarios de Tx que ya analizamos.

Tanto antes con la cifra de $\$ 8.000$ o ahora con la cifra exagerada de "millones de personas", se sirve de hipérboles y del topos de los números para disuadir a los lectores de apoyar esta propuesta de ley por lo desigualitaria que es. Esos millones de personas podrían convertirse en trans, como se dice, volviendo a caer sobre la presunción de que la identidad de género es una elección, una forma de tarea de conversión que aparentemente puede ayudar a recibir tratos especiales como con leyes como las que se abordan, que constituyen un tipo de discriminación a favor de "los" travestis. Más aún, con el uso de la tipografía en negrita se destaca que una ley como esta es discriminatoria en tanto margina a unos "otros" no trans, si bien el pretexto que da origen a la ley es la lucha contra la discriminación. Estos tres elementos (ser trans como elección; referirse en masculino a las travestis, en nombre de toda la población trans; y hablar de esta propuesta de ley como un beneficio), nos permiten ver que hay cierta continuidad ideológica con varios de los comentarios de Tx que ya analizamos.

En síntesis, la línea editorial de Clarín se interesa más por versar sobre la población trans que en el caso de La Nación. Al menos en el período abarcado, solo se publicó un editorial cuyo tema principal era sobre temáticas LGBTIQ, mientras que los dos restantes las abordaban de modo secundario. Mientras que en La Nación se abogaba por la no discriminación, en Clarín dicha premisa era inexistente y, más aún, se emitían juicios que propiciaban la discriminación contra las personas LGBTIQ, especialmente las mujeres trans. En lugar de favorecer los procesos de lucha por la igualdad del colectivo, el medio se ocupa de perpetuar su desigualación de diversas maneras: no se respeta la Ley de Identidad de Género ni el género de una niña trans, se rechazan las propuestas reparatorias para el colectivo trans y se afirma que tales medidas son discriminatorias. Más aún, se acentúa la diferenciación entre las personas trans y aquellas que no lo son en el editorial sobre el subsidio, donde literalmente se dice que cobrarían más que un trabajador o un jubilado. También se representa a la identidad de género como una elección, una decisión a voluntad que solo pueden tomar los adultos sobre sí mismos, y no una menor - en todo caso, aquí decidieron los adultos por ella. Se 
habla de una niña trans en masculino con expresiones como "el nene"; se refiere a su genitalidad y al género que se le asignó al nacer, no al que tiene. Se representa a los infantes trans como personas que atraviesan conflictos internos, que deben ser protegidas y que deben ser acompañadas; este discurso paternalista ya lo habíamos identificado en Tx, el blog del Grupo Clarín. El texto sobre Lulú finaliza con un pedido de discreción para que la cuestión se trate en privado, en el seno familiar. De modo similar, en otro editorial, se alega que la homosexualidad es un asunto privado, algo de la vida íntima. En ambos editoriales se hace un llamado al silencio y se propicia la invisibilización de este sector subalternizado. Tampoco se les otorga voz a los protagonistas de los procesos que se abordan y se incorporan voces de activistas LGBTIQ y de la madre de Luana con el fin de refutarlas. Así, el medio silencia a este sector al representar sus deseos, identidades y prácticas como un asunto privado y secreto, como si fuese un tema tabú.

\subsubsection{Conclusiones provisorias}

Un repaso de los editoriales publicados en La Nación y Clarín entre 2012 y 2015 nos permite observar que el tratamiento de temas vinculados con la población LGBTIQ importa muy poco a estos medios. En cuatro años, encontramos solo seis editoriales que en mayor o menor medida hablan de ella o de algunas de sus reivindicaciones. Cuatro de ellos se expresan específicamente sobre temas de diversidad sexo-genérica; a saber, "La Corte de los EE.UU. y el matrimonio igualitario" (La Nación), "Uganda: persecución a los homosexuales" (La Nación), "Absurdo cupo para travestis y transexuales" (La Nación) y "Cambiar de sexo a los 6 años" (Clarín). El segundo publicó dos editoriales más, donde los asuntos ligados a la población LGBTIQ constituyen un tópico secundario, como en los editoriales "En lo cotidiano está la vida" y “Travestis, cometas, Cristina y un juez".

Así, vemos que La Nación le dedicó más editoriales que Clarín a las leyes de matrimonio igualitario e identidad de género, a la discriminación contra homosexuales y al cupo laboral trans. Este diario se muestra a favor de la defensa de los derechos humanos de todas las personas por igual y predomina el uso de los topoi de humanitarismo y del derecho. Manifiesta que se opone a la discriminación y persecución contra homosexuales así como también a las leyes que pudieran dar 
privilegios o un trato preferencial a ellos y a las travestis por aquello que el medio sostiene que es una elección. Simultáneamente, se expresa a favor de preservar el derecho a contraer matrimonio para parejas heterosexuales $y$ en contra del reconocimiento de las uniones entre parejas homosexuales. También se muestra contrario a las leyes que institucionalizan la violencia en contra de este colectivo, pero no apoya las propuestas de ley que podrían revertir las condiciones materiales y simbólicas que históricamente han violentado a las personas LGBTIQ. Paradójicamente, allí se emplea un discurso igualitarista que aboga por la no discriminación para argumentar en contra de propuestas de ley que podrían poner fin a dicha discriminación.

Clarín, por su parte, se muestra en sintonía con los valores religiosos expresados por el papa Francisco, aunque dice sorprenderse por la decisión de Bergoglio de no juzgar a las parejas homosexuales. ${ }^{64} \mathrm{Al}$ mismo tiempo, ambos medios rechazan el reconocimiento de los derechos de las personas trans. En este sentido, Clarín no adhiere a que se respete el género a una niña trans y tampoco apoya la posibilidad de otorgar un subsidio a las personas trans. En el primer caso sostiene que Lulú no decidió sobre su cuerpo sino que fueron los adultos (padres y autoridades gubernamentales) quienes lo hicieron; en el segundo, se vuelve a emplear el argumento de que un subsidio privilegia a un grupo a costa de otros. Como dice en el editorial publicado más recientemente, con una frase destacada en negrita: "En nombre de la discriminación se discrimina en favor de los travestis".

Tanto en Clarín como en La Nación se habla de "los" travestis para remitir a las personas trans en general. Se invisibiliza la existencia de otras identidades de género y se generaliza la denominación "trans" y "travestis" para remitir a un colectivo amplio que está atravesado por problemáticas y necesidades diversas. Por otra parte, los dos diarios presentan a la identidad de género y también a la orientación sexual como una elección o como una decisión voluntaria. No obstante, y contrario a lo que establece la Ley de Identidad de Género, según Clarín los menores de edad no pueden decidir sobre su propia identidad de género ya que, como dice, "a los seis años no se deciden cosas como éstas". Por tratarse de una elección, no debe usarse para favorecer o privilegiar a un sector poblacional a costas del resto. Por lo tanto, para Clarín y La Nación, la ley de cupo laboral trans o las propuestas del subsidio no son leyes igualitarias. En todo caso,

\footnotetext{
${ }^{64}$ En editoriales anteriores al período que nos compete, el gran diario argentino se había manifestado a favor de que ellas puedan acceder al matrimonio civil, a diferencia de La Nación. Ver el apartado 3.1.2. Los editoriales.
} 
tal discriminación positiva constituye un acto de discriminación negativa en contra de todo aquel que no elige ser trans. Se usa el topos de peligro y amenaza para responsabilizar a las personas LGBTIQ de ser des-igualitarios por solicitar al Estado que se le reconozcan sus demandas. Se crea una imagen negativa de un "otro" que elige una orientación o identidad por la cual espera recibir beneficios, quita oportunidades laborales y que sin trabajar quiere cobrar un subsidio que duplica el salario mínimo, vital y móvil. Estas operaciones discursivas contribuyen a proyectar representaciones desfavorables de las personas no heterosexuales y no cisgéneros dado que se las retrata como personas vagas, caprichosas y discriminadoras. Estos juicios y apreciaciones recaen especialmente sobre la población de adultos trans de clase baja. De este modo, se obtura la posibilidad de que los lectores adhieran a los pedidos de reparación y justicia de las personas LGBTIQ, por los argumentos esgrimidos en su contra, para que tengan una postura afín a la de los diarios.

Ello se refuerza con las voces incorporadas en los textos: si bien los diarios abordan temas de diversidad sexo-genérica, en ningún momento se le da voz a estos sujetos. Hay una tendencia a emplear el discurso referido directo para reproducir citas de autoridad que sustentan las posturas de cada medio, mientras que las citas indirectas y pocas veces las directas son de personas afines al sector LGBTIQ y se las acompaña con expresiones que atenuaran o cuestionaran su legitimidad. Vemos que los medios realizan expansiones y contracciones dialógicas de acuerdo a las actitudes, juicios y valoraciones de su política editorial y que habilitan la publicación de voces que son más cercanas a su posicionamiento editorial. En este sentido, el silenciamiento de las personas LGBTIQ les permite difundir representaciones homogeneizantes y hegemónicas sobre homosexuales y mujeres trans y sobre los procesos complejos que atraviesan. Así, los medios no habilitan el debate ni la problematización sobre ciertos tópicos desde la perspectiva de las personas LGBTIQ y, en todo caso, se deslegitiman sus discursos a través de la difusión de representaciones peyorativas y estereotipantes dela diversidad sexo-genérica.

En suma, observamos que los sentidos que estos editoriales le atribuyen a los actos y expresiones discriminatorios son diferentes a los que recuperan quienes enarbolan las políticas de identidad y diferencia a los que nos remitimos con anterioridad; en otras palabras, los diarios resignifican los sentidos contrahegemónicos de las agrupaciones LGBTIQ con el fin de invalidar las narrativas que resisten a su normalización. Por un lado, estos diarios dicen que los proyectos y leyes a favor de las 
reivindicaciones de las personas LGBTIQ son discriminatorios al otorgar privilegios a unos sobre la base de su orientación sexual o su identidad de género, mientras que también rechazan la discriminación de ellos en su sentido negativo y excluyente. Por el otro, quienes forman parte de ese colectivo dicen que sufren de discriminación y marginación con motivo de su orientación e identidad y ven sus reclamos como válidos. En definitiva, lo que está en disputa son los sentidos de la noción de igualdad y las posiciones de víctima y victimario, que Clarín y La Nación invierten de manera tal que las personas que no son homosexuales ni trans serían víctimas de las personas LGBTIQ, tal como identificamos en los comentarios de los blogs. De esta manera, estos medios promueven miedos bajo la idea de que las personas LGBTIQ amenazan las instituciones y los derechos de los que goza una mayoría cisheterosexual, como el matrimonio, el trabajo e incluso los principios de la Constitución Nacional. Esto, en conjunto con lo que denominamos como la inversión de la retórica de la inversión, opera en pos de desautorizar los reclamos de este sector minorizado a favor del mantenimiento de la hegemonía cisheteronormativa.

Para finalizar, tanto Clarín como La Nación ponen en circulación sentidos discriminatorios sobre la diversidad sexo-genérica, pero dicha discriminación no está motivada solo por la orientación sexoafectiva ni en la identidad o expresión de género de las personas sino también por su clase, por su edad, por ser mujeres y por su (falta de) salud. Con respecto a la discriminación por clase o por situación socioeconómica, notamos que se estigmatiza a las mujeres trans y travestis que ejercen la prostitución o que son trabajadoras sexuales, que en su mayoría pertenecen a sociales bajas y son migrantes. ${ }^{65} \mathrm{Ni}$ Clarín ni La Nación se preocupan por revertir las condiciones materiales y simbólicas inhabilitantes que excluyen a las personas trans del sistema laboral formal. Más aún, tanto desde sus editoriales como desde los comentarios publicados en los blogs, se les niega el goce de derechos básicos como el trabajo al oponerse a la ley de cupo laboral trans y se les niega el derecho a percibir un subsidio como modo de reparación histórica. Esto nos lleva a hablar sobre la discriminación por edad presente en los editoriales de Clarín: allí, al igual que en el blog de Bimbi, se rechaza el otorgamiento del subsidio que estaría destinado para personas trans de cuarenta años o

\footnotetext{
${ }^{65}$ La relación entre migración, clase social, nivel alcanzado de educación y el grado de acceso al mercado laboral formal y al sistema sanitario se explicita en un estudio sobre las mujeres trans y travestis y los hombres trans que residen en Capital Federal. Ver: VV.AA. (2017) La Revolución de las Mariposas. A diez años de La Gesta del Nombre Propio, Buenos Aires: Ministerio Público de la Defensa de la Ciudad Autónoma de Buenos Aires.
} 
más y, en simultáneo, se rechaza el reconocimiento del género de Lulú por ser menor y por, como se argumenta, no tener edad para decidir sobre estas cosas; este componente edadista también aparece en los comentarios sobre Luana de BP. ${ }^{66}$ Por último, identificamos la presencia de un sesgo machista que es transversal a los dos medios y a los dos blogs, que lleva a acentuar la discriminación sobre la población de mujeres trans y travestis por el hecho de ser mujeres. Respecto a las cuestiones ligadas con la salud, se asocia sobre todo las mujeres trans y travestis con las enfermedades mentales, repatologizando las identidades trans. Y si son prostitutas, además, se asume que son promiscuas y que son portadoras enfermedades de transmisión sexual y de HIV/SIDA, poniendo en riesgo la salud de todos; por lo tanto, son depositarias de discriminación y violencia por su real o supuesta carga seropositiva, convirtiéndose así en el rostro del miedo, del peligro y del riesgo.

\footnotetext{
${ }^{66}$ Por ejemplo, en BP encontramos comentarios que comparan la responsabilidad de los adultos sobre el otorgamiento del DNI de Luana y su respaldo sobre la "decisión" sobre su género con dejar a un infante manejar un auto en la autopista. El texto que sigue lo ejemplifica: "Un niño de 6 años no esta en condiciones de nada, y son los adultos los que deberian tener la lucides para darse cuenta la verdad. Acaso si un niño de 6 le pide a un adulto manejar un auto, el adulto le entrega las lllaves asi nomas? ese tipo de criterio deberia primar en los adultos, pero lamentablemente en este caso no fué asi...y le siguen aumentando el delirio al niño al seguirle la corriente...total, si las cosas despues salen mal, el que sufre el daño es el niño" ([BP1043]).
} 


\section{5. "Que haya debate”: la moderación y la libertad de expresión}

Aquí nos explayamos sobre las entrevistas que realizamos a Dema y a Bimbi, con quienes dialogamos sobre su función como moderadores de los blogs, sobre los comentarios que se publican y sobre su postura con respecto a la eliminación de ellos. Luego nos extendemos sobre los intercambios que tuvimos con referentes y activistas LGBTIQ en torno a los debates sobre la actualización de la ley antidiscriminatoria.

\subsubsection{Boquitas pintadas}

En la entrevista que hicimos con Verónica Dema el 29 de enero de 2015, nos cuenta que creó el blog por iniciativa propia. Decidió presentar un proyecto para abrir un blog en La Nación tras la sanción de la Ley de Matrimonio Igualitario cuando vio que "las notas que [ella] publicaba en LaNación.com tenían un éxito bárbaro en cuanto a que había gente que necesitaba y estaba muy interesada en leer algo que hasta entonces no se había leído”. Agrega que “eran historias no contadas, lo 'nefando'; no se hablaba de estos temas y la verdad que, más allá de que el público de La Nación muchas veces estaba en contra [de esos temas], [ese público] iba en contra de algo que no sabía ni qué era".

En un principio pensó la propuesta con una compañera pero finalmente lanzó el blog por su cuenta tras recibir la aprobación del medio. Cuenta que casi todos los blogs en La Nación son individuales. Para ella, su blog está dirigido a todo el mundo. En sus palabras: "no me dirijo a la comunidad LGBTIQ sino a todo el mundo. [El blog] tiene la intención de llegar al público general, lector de La Nación y gente que nunca leyó La Nación".

Los temas que aborda son variados y se van nutriendo de los relatos que recibe de la gente. Cuenta que al principio hablaba más sobre experiencias de salida del closet, pero luego pasó a hablar de otros temas vinculados con las vidas de estas personas; como dice, "historias de gente común". Ellos incluyen sus historias de amor o desamor, sus relaciones con sus familias, sus experiencias en el trabajo y en la escuela, sus deseos de ser padres o madres y las marcas que les dejó la discriminación. De manera sintética dice que "no es ya la novedad "cómo dije que soy gay' sino "qué me pasa en mi vida". Si bien principalmente aborda temas de sexualidad, Dema busca retratar la vida de 
artistas LGBTIQ, obras de teatro, libros, películas y sitios web que puedan ser de interés para todas las personas. Ella escribe los posteos pero también hay personas que colaboran con ella de manera voluntaria, como hicieron Alejandro Viedma, Naty Menstrual, Facundo Soto, Gustavo Pecoraro y Daniel Gigena.

Además de redactar notas para La Nación y las entradas para el blog, Dema se ocupa de la moderación del espacio. Opina que "lo más difícil del blog [es] saber hasta dónde se permiten ciertas cosas". Pero para ella también es una tarea difícil porque es su primera experiencia como bloguera, porque se dedica a eso y "a mil cosas más" y porque el sitio "lo manejo completamente yo". Dice que nadie de La Nación edita ni modera nada. Sin embargo, ellos sí le han preguntado cómo maneja los comentarios y a modo de sugerencia le han dicho: "dejalos debatir, que sea un espacio de debate, porque tampoco vas a dejar solamente a la comunidad LGBT". Agrega que: "obviamente por ser un espacio gay-friendly creo que lo que más tengo que preservar es a las personas de la comunidad LGBT y a las que no agreden". Y opina que, por tratar temas de diversidad sexual y generarse más polémica que en otros blogs, hay opiniones tan dispares que vuelven más “complicada” la tarea de manejar ese espacio.

Indica que una dificultad adicional consiste en determinar cuál es el límite para borrar un comentario violento sin hacer sentir mal a su autor. Dice que los criterios de publicación de comentarios van cambiando y a veces dependen de lo que soliciten los autores o los comentaristas de los artículos. Señala que su blog es un espacio plural que no admite la agresión, aunque ve que allí se hiere gente. Por ello, trata de escuchar lo que le dicen los lectores y cuenta que hay quienes le dicen "por favor, dejanos discutir" y otros que le dicen "no, esto no lo publiques" o "esto me hace mal". Por ejemplo, cuando Vida Morant escribe y publica entradas en el blog, le pide a Dema que no permita que se publiquen comentarios, que no lo abra al debate. Pero salvo en esos casos, todos los comentarios que se escriben se publican. A los agresores intenta mandarles un correo para explicarles por qué sus textos van a ser eliminados, pero a veces sus mails son ficticios y no logra contactarlos.

Por lo general, entonces, todos los comentarios se publican porque Dema los aprueba, si bien admite que quizás se le puede pasar por alto algún comentario que debería eliminar. Ella siente que los comentarios ocupan un lugar central en los artículos y que a veces los debates que se generan en los comentarios son más interesantes que las historias que contienen los posts. Piensa que los comentarios completan al texto que disparó su publicación. Pero algunos de ellos son agresivos y transgreden lo que 
establecen las condiciones de uso de los blogs de La Nación. En este sentido, Dema opina que ese reglamento "no lo leen o no [les] importa [a los comentaristas]".

Por otra parte, dice que esta es una tarea cansadora y también difícil por no haber consenso entre qué constituye una agresión y qué no lo es. Ante los usuarios que opinan que ella censura sus opiniones, reconoce que algunas personas sienten que lo que escriben no es una agresión sino una verdad. El ejemplo que da es cuando alguien escribe: "esta persona es un hombre porque tiene pito y no una mujer como ella dice". Para algunos esto no es una ofensa y para otros sí, como puede ser el caso de una persona trans. Cuenta que ella personalmente tuvo que recibir la agresión para percatarse de lo que podría sentir alguien que se identifica como mujer y que es tratada en masculino. Sobre este suceso cuenta lo siguiente: "Alguien me hablaba como un varón; yo me di cuenta que me lo hacía para herirme y realmente te hiere. [...] A mí me pareció tan fuerte que dije "eso debe sentir todo el tiempo la gente trans"'. Dice que desde ese entonces trata de ser más cuidadosa con las personas trans y procurar que se respeten sus identidades de género, si bien admite que debe haber posts antiguos con "cualquier cosa" y que tendría que ponerse a revisar y borrar comentarios anteriores para cumplir con ese objetivo.

Para ella, en su blog hay personas que a grandes rasgos pueden colocarse en "dos bandos":

[Unos] son los que defenestran el espacio y que incluso [dicen] "te vamos a denunciar a la Nación" o que incluso me han agredido [diciendo] "sabemos dónde trabajás, sabemos dónde vivís". Es gente que más bien viene a reforzar prejuicios y que no está abierta a escuchar nada. Tiene la idea de la familia como la conciben ellos: varón, mujer, nenitos. No hay forma de entrarle a esa gente [...]. Y por otro lado, desde el otro extremo, están los que quieren aportar y discutir; [a esos] los admiro, te juro [...] Son militantes para mí, son militantes, no de alguna organización; [son] militantes en su vida.

En definitiva, los primeros "espantan a los que realmente quieren discutir e intercambiar" opiniones. Observa que por ello ahora no hay tanta contienda como antes: "[hoy] se quedan solos los que gritan, [mientras que] los gays que siguen participando son por ahí más abiertos y pacientes y siguen dando batalla" o ya no comentan. Desde su punto de vista, estos tipos de intercambios no son exclusivos de los blogs y los ve en los comentarios de los diarios digitales, por ejemplo. Para ella, los agresores "no nacen 
de un repollo, están en la sociedad". Agrega que "la agresividad que ves en la calle está después en los comentarios. [...] [El agresor es] el mismo que después te choca [con el auto] si puede si cruzás la [avenida] General Paz". Su explicación para ello es que "somos una sociedad violenta, fragmentada, que no entiende al otro. Al que está al frente no lo entendemos porque es distinto".

Con respecto al vínculo de Dema con los usuarios, como ya dijimos, ella es la única responsable de moderar los comentarios de su blog. Ella debe decidir si acepta que estos se publiquen, aunque dice que por lo general y por falta de tiempo para mirar en detalle, todos o casi todos los comentarios son publicados, salvo cuando usuarios o autores de las notas solicitan borrar textos o cerrar la sección de comentarios. Pero si revisamos el corpus, vemos que con frecuencia los usuarios se dirigen a Dema en calidad de moderadora para criticar su decisión de eliminar ciertas intervenciones:

[BP1439] Roy: La censura es terrible en este blog...pensaran que si esconden los comentarios adversos la sociedad los acepta mas? jajaja

[BP1441] manuel a Roy: es asi roy, ya me censuraron varios comentarios...y despues los homosexuales se quejan de que los discriminan!!! pero ellos son los primeros en encerrarse en un guetto y no permitir expresiones adversas bien fundamentadas.

[BP1460] manuel a C Méndez: el problema con vos y muchos de los gays que escriben aca que son tan binarios y simplistas que califican asi:

comentario pro gay: excelente. comentario anti gay: ignorante, homofobico, insultante, agresivo y unos cuantos adjetivos mas. Por lo tanto lo que quieren es un blog con solo comentarios positivos...saquense la careta de una vez.

[BP1468] Andres Sotto a Josedelbarrio: [...] Si existe un blog gay, siendo los gays los primeros en reclamar que son discriminados y exclcuidos...resulta poco coherente(por ser suave), que en el blog gay haya censura y exclusion tambien.

En estos comentarios vemos que los usuarios Roy, manuel y Andres Sotto manifiestan sentirse excluidos y discriminados ya que según ellos se "censuraron" sus posts. De este modo, y una vez más, vemos como las personas que sostienen posturas distantes a las de los autores de los posts manifiestan sentirse discriminadas y vulneradas por las personas LGBTIQ. Esta operación discursiva, a la que ya nos hemos referido con anterioridad, se complementa con la acusación de que se está atropellando el derecho a la libertad de expresión de las personas no trans y no homosexuales que publican textos con posturas 
que sus propios autores representan como comentarios bien fundamentados con expresiones adversas o anti-gay.

Asimismo, hay miradas diferentes sobre la cantidad de comentarios que se eliminan, como se observa en los siguientes textos:

[BP932] roger16 a C Méndez: [...] no ve el abrumador repudio en la sociedad a este tema?? si no moderaran los comentarios tendrian miles de respuestas negativas.

[BP1459] C Méndez a manuel: Si veo la cantidad y la calidad de muchos comentarios que hay aquí no me queda otra que decir que la moderación es muy permisiva (lo cual me parece bien). Si no te dejaron pasar un comentario, fijate sino contenía lenguaje muy agresivo. Decir que está mal como llevamos nuestras vidas no alcanza para que te "censuren".

Mientras que roger 16 piensa que habría más comentarios negativos si no fuese por el ejercicio de moderación, $C$ Méndez participa del debate aduciendo que solo se eliminan los textos agresivos, y que en todo caso es positivo que la moderación sea escueta. Es decir, ambos usuarios valúan de modo diverso el ejercicio de la moderación: para uno es excesivo, para el otro es muy laxo.

Por otro lado, notamos que Dema también participó de los debates. En los posteos seleccionados, encontramos que publicó un solo comentario en la entrada “"Anita y sus dos mamás', un cuento infantil para pensar las familias diversas" (19/11/2013). Su escrito dice lo siguiente:

[BP57] vdema (Moderador) a susan.tidad: Increíble la cantidad de barbaridades y mala información del video compartido por sasan.tidad. Ni sé si vale la pensa verlo, pero aprobé el comentario para que nadie se sienta censurado. Saludos

Aquí vemos que el usuario de Dema, vdema, tiene un perfil de Moderador. En su texto se dirige a susan.tidad para responder a su comentario anterior, en el que había compartido un video de YouTube acerca de la ideología de género. ${ }^{67}$ En esta única intervención, valúa negativamente el contenido que publicó su interlocutora y expresa que permitió publicar su comentario "para que nadie se sienta censurado". Le responden

\footnotetext{
${ }^{67}$ Revisamos el enlace en diciembre de 2016 y observamos que YouTube lo borró porque consideraba que su contenido incitaba a la violencia y al odio.
} 
tres usuarios, de los cuales uno avala su opinión y los dos restantes la critican. Por ejemplo, Mario Aguirre le contesta:

[BP71] Mario Aguirre a vdema: y porqué son barbaridades y mala información? solo porque usted lo dice y lo comparte ? perdón, este no es un blog que pide tolerancia?

Aquí no solo se interroga cuál es el propósito del blog sino también se interroga a Dema y a sus criterios de aceptación de los comentarios dado que según esta persona ella no es tolerante con quienes piensan distinto. Más aún, dicen que se discrimina al que no piensa igual que ella:

[BP125] luis a mario: ademàs -vaya paradoja- en un blog que se supone son anti-discriminatorios te discriminan... [...] solo falta que te digan marica por no pensar como ellos...

Por otra parte, nos parece pertinente recuperar algunos de los 43 comentarios eliminados que Dema copió y nos envió a través de varios correos electrónicos entre febrero y marzo de $2015 .{ }^{68}$ Estos textos pertenecen a siete artículos que no forman parte de nuestro corpus. ${ }^{69}$ Sin embargo, nos ayudan a complementar y a profundizar sobre nuestro análisis y nuestra reflexión con respecto a la relación entre Dema y los usuarios de su blog. Veamos estos ejemplos:

\footnotetext{
${ }^{68}$ Por el material que nos facilitó Dema, identificamos que 27 de los 43 comentarios eliminados (62,79\%) provienen de una sola dirección de IP con 21 seudónimos distintos: Ale, Almagrino, Aquiles, ARG, ARGENTO, BairesW, Carlita Juarez, Fer97, Guido, Jaz, Juan Palotes, LN99, Lu, Lucia Iturralde, Lup, Sofi Iturralde, Sofi96, Sol de Rubi, Tucson1996, Veronica Dema CENSURA y VERONICA DEMA DEJÁ DE CENSURAR. Ocho de esos comentarios emanaron de un único electrónico de Outlook, lo que nos lleva a pensar que se trata de una sola persona. Los diecinueve restantes tenían mails distintos, pero la misma dirección de IP. Luego encontramos una segunda dirección de IP con seudónimos y mails diferentes de donde se publicaron tres comentarios. Geolocalizamos ambas direcciones de IP a través de Google y el sitio web DB-IP (https://www.db-ip.com). Así percibimos que su proveedor es Fibertel/Cablevisión y que parten de la misma ubicación en la zona de Tribunales (Ciudad Autónoma de Buenos Aires). Esto resulta llamativo por la sospecha de una usuaria de que existen personas enviadas por el medio para agredir a los participantes. Nótese que solamente contamos con los correos electrónicos y las direcciones de IP de los comentarios que Dema eliminó y que compartió con nosotros. Por lo tanto, no nos es posible observar estos datos en el corpus de comentarios publicados en BP así como tampoco podemos conjeturar acerca de la posibilidad de que haya una persona que se cambia el nombre para hacerse pasar por más personas, aparentando un rechazo generalizado respecto a las personas LGBTIQ.

${ }^{69}$ Sus títulos son: “'Ahora queremos adoptar un hijo” (29/08/2011, 2 comentarios borrados), “¿Cómo va a ser gay si está casado y con hijos?" (20/06/2012, 1 comentario eliminado), “Me enamoré de un rubio con ojos más azules que el mar', dice Jonatan” (22/01/2015, 3 comentarios eliminados), “¿Donar sangre? Vos no, por homosexual" (03/02/2015, 13 comentarios borrados), "Vos estás enfermo', le dijo el sacerdote a Gonzalo cuando supo que era gay" (19/02/2015, 11 comentarios eliminados), "Dafne y su historia como crossdresser" $(24 / 02 / 2015,5$ comentarios eliminados) y "Cuando ver porno gay era una odisea" (02/03/2015, 8 comentarios borrados).
} 
[E_BP5] LN99: la autora del blog es torta. Pobre enferma mental

[E_BP6] $L u$ : la primera vez que en La Nación echan a los lectores. Increible. Usted [Dema] alli es un cuatro de copas, tenga cuidado a la hora de elegir enemigos. No todos somos como usted. Besos.

[E_BP14] VERONICA DEMA DEJÁ DE CENSURAR: EN LA NACION SABEN QUE CENSURÁS LOS COMENTARIOS QUE NO TE GUSTAN??? ESO LO CONTÁS??? LA FAMILIA MITRE LO SABE? ÉSTO NO ES CORDOBA EHH TIC TAC TIC TAC

[E_BP24] Veronica Dema CENSURA: veronica dema por qué borra comentarios???? borra lo que no le gusta!, no hay libertad de expresión o usted decide la linea editorial de La Nación? una verguenza que en un diario centenario pase esto, escribe para La Nación no para Página 12 o un diario $\mathrm{K}$ que usted tanto admira. Las cartas a la familia Mitre denunciando su censura también van a llegar. No se olvide que usted es una simple "empleada", del otro lado no tenemos esa "desgracia". Cuide su trabajo, y piense bien antes de censurar. Sea inteligente. Saludos

Ahh y escriba mejor, sus ultimas notas en la home tenían faltas de ortografía y estaban mal redactas, su historial no la favorece.

En líneas generales, los comentarios eliminados versan sobre los hombres homosexuales y sus supuestas enfermedades mentales, su promiscuidad y su carga seropositiva. Se dice que dan asco, son raros, son anormales y desviados, que deberían curarse y no se les debería permitir donar sangre ni tener hijos; incluso aparecen referencias bíblicas para respaldar estos juicios. Pero varios se refieren a Dema, como en los cuatro textos que aquí recuperamos. Allí observamos que desde los nicknames y el contenido de los comentarios se acusa a Dema de censurar a los lectores de La Nación. Se la caracteriza como "torta", "pobre enferma", "un cuatro de copas" y "una simple empleada" que redacta mal y tiene faltas de ortografía con el fin de descalificarla como persona y como profesional. Estas nominaciones y predicaciones se ven intensificadas por el uso de preguntas, las advertencias hechas en modo imperativo y el empleo de las mayúsculas. A estos ataques se le suman las amenazas que dicen que Dema podría perder su trabajo por borrar comentarios y por ir en contra de la línea editorial del diario; más aún, se conjetura que su afiliación política es kirchnerista y se le sugiere buscar empleo en Página/12. Esto nos permite suponer que los lectores y comentaristas de BP identifican que Página/12 y La Nación tienen líneas editoriales 
opuestas, y que el blog debe responder a la línea editorial del diario; de allí se desprende la base de la crítica de la presunta censura. Asimismo, podemos conjeturar que, desde la perspectiva de los usuarios, la línea editorial del diario de los Mitre se orienta a promover la libertad de expresión. Pero, si repasamos los comentarios eliminados y los publicados y los editoriales analizados, podemos agregar que la línea editorial, según los comentaristas de BP, se vincula con la libertad religiosa, con la Iglesia católica, con una postura política contraria al kirchnerismo y con una mirada adversa sobre la población LGBTIQ y su "atropello" sobre los derechos humanos.

En suma, vemos que a través de la publicación y eliminación de comentarios y a partir de sus intervenciones y su entrevista, Dema ocupa el lugar de un moderador que podríamos denominar abstencionista ya que ella se abstiene de participar en el blog al no involucrarse en los debates escritos; hizo un solo comentario sobre un total de 2.033 que se publicaron en los artículos seleccionados en un lapso de cuatro años (20122015). Pero no por ello evita contactar a sus lectores de manera privada por correo electrónico: en la entrevista nos informó que intenta escribirles para explicarles por qué se eliminaron sus comentarios, si bien a veces espera que "se ubiquen solos". Asimismo, se abstiene de eliminar comentarios por la sugerencia del medio de "que haya debate", por pedido de los usuarios y por su propia carga laboral. Sin embargo, por los comentarios eliminados que nos envió, por su testimonio y por las críticas y amenazas de algunos comentaristas, sabemos que sí borra algunos textos aunque sea en un grado bajo. Quizás ello se deba a que en el blog busca preservar los derechos de las personas LGBTIQ y los de quienes no agreden a otras personas, tal como señaló en la entrevista. Por último, identificamos que hay usuarios que sienten que sus derechos son vulnerados con la publicación de ciertos comentarios y ellas no son solo los sujetos LGBTIQ: nuevamente, las personas cisheterosexuales se representan a sí mismas como seres que son afectados por blogs como éste, por los comentarios de usuarios no cisheterosexuales y por la eliminación de sus intervenciones. Ellas denuncian censura para demandar la publicación de sus comentarios en un espacio virtual que está vinculado institucionalmente con La Nación y que suponen que tiene una perspectiva próxima a la del diario.

\subsubsection{Tod@s}


En la entrevista realizada el 23 de septiembre de 2015, Bruno Bimbi comenta que Tx nace a partir de una idea del director de Todo Noticias, Carlos De Elía. Él le propuso hacer algo similar a la columna "El placard", aquella que Bimbi escribía para el diario Crítica de la Argentina, pero ahora en versión digital. Dice que en Tx busca abordar temáticas de diversidad y disidencia sexo-genérica pero, al igual que Dema, quiere llegar a un público más amplio. En sus palabras: “es un blog que está dirigido a todas las personas que tienen Internet, que hablan español y que quieran informarse. [...] [Está] pensado para el público en general, inclusive para las personas que tienen prejuicios; el blog puede ayudarlos a sacárselos". A diferencia de Dema, él es el autor de todas sus entradas del blog, en las que busca hablar sobre mitos que circulan en el imaginario social, como por ejemplo el mito de que la homosexualidad es una elección o el mito de que en una pareja gay hay alguien que hace de hombre y alguien de mujer. Pero también se ocupa de temas de política, religión, derechos civiles, literatura y cine LGBT.

Para Bimbi, en su blog no existe la función del moderador, pero aclara que esta figura sí existe de modo general en todos los blogs de TN y se activa solo en casos particulares. Dice que todos los comentarios se publican sin pasar por ningún filtro:
Sacando casos muy, muy extremos, los comentarios por lo general no son moderados. [...] La gente deja un comentario y el comentario se publica de forma automática, no necesita ser aprobado. Ahora, si hay comentarios que son extremamente agresivos o que tienen apología del delito o cosas muy graves y [los moderadores] los ven, los borran. Pero salvo que sea una cosa exageradamente agresiva, no hay moderación.

Con respecto a cómo se acciona la moderación, nos indica que él lee los comentarios y solicita la intervención de los moderadores según el caso:

Pocas veces en la historia del blog he pedido que bloquearan a alguien. Hay un tipo que se llama Néstor Lamuedra, [...] se crea varias identidades, tiene tres o cuatro nombres distintos (yo sé que es él porque dice siempre lo mismo). En algunas [ocasiones] firma como Néstor Lamuedra; en otras firma como Roberto Baldini. Tiene dos o tres nombres más. Ese fue uno de los pocos casos que yo llamé a TN, hablé con la gente que se encargó, [y dije] "bloquéenlo a este tipo porque es insoportable, en cada nota que escribo entra para vomitar todo su odio". 
Bimbi dice que lee todos los comentarios que se publican en su blog y responde a varios de ellos, aunque trata de ignorar los ataques personales y no responderlos para no entrar en su lógica agresiva. Sin embargo, como veremos más adelante, su participación puede verse como un modo de moderación, si bien en su blog él no puede eliminar ni filtrar comentarios, como sí hace Verónica Dema, dado que su cuenta no tiene los permisos para ello.

Desde su punto de vista, todos los blogs y las secciones de comentarios de los diarios deberían permitir que se publiquen todas las opiniones, por más que estén en desacuerdo con lo que se escribió. Para él, este criterio también favorecería que el blog tuviese más visibilidad y aumentaría la cantidad de lectores. No obstante, cree que publicar todos los comentarios podría ser contraproducente:

Si una persona deja insultos, amenazas o cosas por el estilo, sí me parece que el comentario hay que borrarlo. Y si la persona insiste, hay que bloquearla porque eso, además de ser violento, ahuyenta a otras personas a las que les gustaría participar de una discusión seria. Si vos leés la nota y querés dejar un comentario, y cuando vas a dejar el comentario ves que hay una amenaza de muerte o una catarata de insultos, te vas, ¿no? [...] Entonces se transforma en un espacio que está tomado solo por las personas que están insultando.

En este sentido, guarda una postura similar a la de la responsable de BP ya que ambos argumentan que los comentarios hostiles alejan a quienes están interesados en participar del espacio y que sienten que serían víctimas potenciales de ataques.

Al igual que Dema, Bimbi identifica dos tipos diferentes de comentaristas:

[Hay] lectores asiduos, personas que leen siempre el blog, que están vinculadas con el blog y que hacen comentarios sobre las notas, sea para hacerle críticas, para elogiarla, para dar alguna opinión sobre un tema. Y están los odiadores [...]. Es la gente que entra solamente para dejar insultos y para dejar ofensas.

Al mismo tiempo, observa que estos "odiadores" están en otros sitios, como en las páginas de los diarios Clarín, La Nación o Perfil. Pero estos discursos de odio que él ve en los comentarios y en los medios de comunicación en general no los ve en otras esferas sociales. Se trataría entonces de un pequeño grupo muy activo que "está todo el tiempo en Internet dejando insultos en distintas páginas". Según Bimbi, "hay mucho odio en Internet", aunque para él esto no representa lo que sucede en el resto de la 
sociedad. A diferencia de Dema, afirma: "no me parece que las personas reales estén enfermas de odio" (sic).

Su relación con los usuarios es diferente que la de Dema por varios motivos. En principio, y tal como nos explicó, él no cumple con la función de moderar el blog y únicamente solicita la intervención de los moderadores de TN Blogs en el caso de encontrarse con "una exageración". Además, en su blog los comentarios se publican automáticamente y sin mediar filtro alguno, por lo que no se los debe aprobar de forma manual. En todo caso, tras su publicación, Bimbi podrá demandar su remoción o el bloqueo de sus autores. Ello lo explica en el comentario que sigue:

[TX555] darsu suar a Bruno Bimbi: Bruno. mira, soy hetero pero siempre me enerva ideas retrogadas como las que te han ido tirando.

A mi entender no deberias entrar en este ida y vuelta con personas que dicen llamarse religiosas y corroen el principio real de toda creencia que es el AMOR. La verdad no logro entender ese odio visceral que tienen contra las personas que viven su sexualidad de una manera distinta a la de ellos [...].

[TX556] Bruno Bimbi a darsu suar: Es difícil. Siempre tuve por regla leer los comentarios de todos los lectores y, en la medida de lo posible, responder. Leo muchas cosas inteligentes, como tu comentario, y eso me da ganas de seguir leyendo. También leo cosas con las que no estoy de acuerdo, pero bien fundamentadas y serias, y las respondo. Otros escriben cosas que me parecen muy mal fundamentadas, pero dichas con buena fe. Trato de responderles también, con humildad y respeto. Hay otros que sólo entran para insultar, agredir y decir mentiras con absoluta deshonestidad: a esos voy a empezar a bloquearlos, porque ensucian el foro y espantan a quienes quieren conversar y debatir en serio. Saludos.

En este fragmento también vemos cómo caracteriza su vinculación con este sitio y cómo percibe a las intervenciones que allí aparecen. Indica que trata de leer todos los comentarios, lo que representa un modo de vigilancia y control sobre el espacio; y dice que a veces los responde, lo que nos lleva a analizar los comentarios que le dedican los usuarios y los que él les dirige. Así, observamos que Bimbi publicó un total de 213 comentarios sobre un total de 3.062 en los artículos que forman parte de nuestra selección. Sus contribuciones no son todas iguales. Por ejemplo, a un usuario que Bimbi considera que busca insultar y agredir, le escribe: 
[TX45] Bruno Bimbi a Carlos Martin: Carlos, si seguís entrando a este blog nada más que para insultar y agredir, vas a ser bloqueado para participar del foro. Tus agresiones cansan. Saludos desde Río de Janeiro.

Pero también hay ocasiones en las que Bimbi acompaña la amenaza de bloqueo con ataques personales, como en los ejemplos que siguen:

[TX941] Bruno Bimbi a Pablo Ruiz Santa Ana: Mirá, pedazo de estúpido, cuando vos todavía quizás ni te habías enterado del robo de bebés en la dictadura, yo estaba organizando Teatro por la Identidad en Avellaneda con las Abuelas de Plaza de Mayo. Así que lavate la boca antes de hablarme de "lecciones de moral".

[TX330] Bruno Bimbi a Ernesto Lamuedra: Lamuedra, usted miente tanto que no vale la pena discutir, porque volverá a mentir y esto se hace largo. Búsquese una vida y no moleste más. Y vaya al psiquiatra, a ver por qué tiene esa obsesión enfermiza contra los gays. Es evidente que está muy enfermo de la cabeza.

Luego, en otro texto escribe:

[TX332] Bruno Bimbi a EMILIANO: Este blog es mío, ¿sabías? Si seguís insultando o hablando en ese tono grosero, maleducado y violento, el que no va a poder opinar más acá sos vos.

Por otro lado, hubo un post, "El Papa pide perdón a los homosexuales" (01/01/2012) que algunos usuarios lo confundieron con una noticia y luego le reprocharon al autor por la confusión y el daño ocasionado. Veamos dos ejemplos sobre cómo Bimbi respondió a sus lectores:

[TX61] Bruno Bimbi a Fernanda Venegas: [El post] Es una provocación: ¿qué pasaría si fuera cierto? ¿Cuántas vidas cambiaría? Ojalá nos sirva para pensar... Feliz año!!

[TX87] Maximiliano Comán: Sos un tarado man, como vas a hacer este chiste. Imbecil

[TX88] Bruno Bimbi a Maximiliano Comán: Un abrazo para vos también. 
En el primer caso, el activista utiliza el recurso de los comentarios como una forma de explicar el objetivo de su nota, que buscaba provocar al lector a reflexionar sobre lo que había publicado y emplea preguntas retóricas para pensar sobre el tema. En el segundo, en cambio, se dirige a Maximiliano Comán de forma irónica para enviar un abrazo a quien acababa de insultarlo llamándolo "tarado" e "imbécil". De todos modos, Bimbi no responde todos los mensajes, tal como denuncia pepa en un comentario dirigido a Bruno: ([TX2693]) "Solo contestas los comentarios que te conviene" previos:

Hay otros textos en los que los usuarios repudian la eliminación de textos

[TX572] Carlos Dip Fadel: Amigo Bambi: No le tema ala verdad . No borre los comentarios. No tenga miedo, es cristofóbico y se le nota

[TX1688] ArturoGonzalo TeceiraLampa: CHE TN PORQUE ME BORRAS EL POST ????? MIS COMENTARIOS CONSERVADORES TAMBIEN FORMAN PARTE DE LA LIBERTAD DE EXPRESION ...

[TX1705] ArturoGonzalo TeceiraLampa: mal intolerante TN nome dejas expresarme .. borras todo.. solo dejas a los ATEOS QUE POSTEEN !!!

[TX2018] Sonia Palavecino: Expreso mi repudio hacia esta publicación [“El Papa que huyó por amor (y se fue a vivir con su secretario)"] por ser falsa, tendenciosa y carecer de pruebas "verdaderas", la cual atenta contra la dignidad de nuestro líder religioso, Benedicto XVI quien siempre tuvo una conducta intachable, además la nota está abierta a comentarios sumamente ofensivos contra la imagen del Papa y la Iglesia Católica y algunos comentarios en su defensa fueron borrados de manera totalmente antidemocrática sin respetar la pluralidad de opinión y darnos a los católicos la posibilidad de defender a nuestro líder.

[TX2891] Marcos Buso: sigan eliminando comentarios constructivos tn, Censura pura ! solo dije la verdad en mi comentario, dan verguenza incompetenes, comprados pagados vendidos. Lo unico que hacen es defender intereses agenos, recueden que sus hijos son parte de la sociedad, sigan asi, clarin es lo mismo que ustedes, periodistas ya no existen

En estos ejemplos notamos que sus autores apelan al uso de signos lingüísticos como las mayúsculas y los signos de exclamación e interrogación para enfatizar sus quejas por los comentarios que fueron borrados; según ellos, la eliminación de sus textos busca favorecer a un grupo de interés particular, que se presupone que está conformado por ateos y no conservadores. Los comentarios borrados son defendidos como "verdad", 
como "parte de la libertad de expresión" y como "comentario constructivo". Asimismo, se ataca a TN y a "Bambi" de ser antidemocráticos y de censurar la voz de los católicos. Más allá estas denuncias de censura, en Tx hubo comentarios de personas que defendían a la Iglesia, al catolicismo y a Benedicto XVI y que fueron publicados a pesar de cometer actos discriminatorios, como vimos en apartados anteriores.

Para finalizar, vemos que Bimbi se distancia de la función de moderador pero tiene una interacción con los usuarios que es más activa que la de Dema: lee todos los comentarios, responde a algunos de ellos, ofrece explicaciones, opina en las discusiones o bien ataca y amenaza a sus interlocutores. Asimismo, publica más intervenciones que Dema (213 vs. 1) y participa en los debates; en algunos intercambia argumentos con otros comentaristas pero a veces los ataca y amenaza. Por lo expuesto anteriormente, podríamos decir que su estilo de moderación es mediador porque busca encausar los intercambios y procura que entre los participantes no haya agresión mediante el pedido de eliminación de aquellas contribuciones que pudieran obstaculizar este objetivo y la solicitud de bloqueo de las personas que insultan y agreden a otras. Por otra parte, notamos que hay usuarios que identifican al blog con TN y con Clarín, y que le atribuyen similitudes con el diario de los Mitre. En ambos blogs notamos que se aduce que existe un tipo de discriminación religiosa que conduce a la eliminación de los comentarios que no coinciden con la postura de sus responsables, Bimbi y Dema. En ambos blogs se denuncia que se eliminan y se censuran los comentarios de los católicos y de quienes publican "verdades" sobre las personas LGBTIQ. Los usuarios afectados por la moderación dicen que son discriminados por las mismas personas que piden tolerancia y que luchan contra la discriminación; por ello, algunos comentaristas manifiestan que en los blogs se reemplaza la discriminación por orientación sexual y expresión e identidad de género por discriminación religiosa.

\subsubsection{Testimonios de referentes y activistas LGBTIQ}

¿Dónde y cuándo es legítimo trazar la línea que separa el derecho a la libertad de expresión y a una vida libre de discriminación en Internet? Siguiendo a Herring et al (2002), existen dos posturas que entran en disputa en lo que refiere a la libertad de expresión en los entornos virtuales. La primera es la visión comunitaria, que busca preservar los espacios donde participan los sectores minorizados para proteger la 
libertad de expresión y el bienestar de dicha comunidad. La segunda es la visión libertaria, que se opone a regular Internet y defiende el derecho individual a la libertad de expresión, incluyendo la difusión de contenidos que puedan ser hostiles y discriminatorios para un grupo. En el primero podríamos ubicar a Dema junto con su moderación autocrática y su participación abstencionista; y a Bimbi dentro del segundo, más próximo a un laissez faire comunicacional que tiene ciertas reservas. Sus criterios para delimitar dónde se modera y dónde no, como vimos, son cambiantes, difusos e inciertos, y dependen de múltiples factores como su percepción, su tiempo disponible, su carga laboral y el interés del medio, de los usuarios y de los autores de los posteos. Por otra parte, como ya habíamos señalado, hay una dificultad adicional que remite a la pluralidad de interpretaciones sobre qué constituye un acontecimiento violento y qué no lo es, dado que victimarios, víctimas y testigos pueden no coincidir o no en sus interpretaciones. Y según O’Sullivan y Flanagin (2003), esto también se aplica a los entornos virtuales, donde las interpretaciones de los sentidos que se ponen en circulación a través de los comentarios escritos dependerán en parte de las intencionalidades de los comentaristas, de las competencias contextuales y socioculturales de los lectores y del conocimiento que tengan sobre ellas los moderadores y todos los observadores externos a esa situación comunicativa.

Como apunta Myriam Pelazas, "la libertad de expresión no debería entrar en colisión con el derecho a no ser violentado/a" (2016: 38). Para ver cómo transitar estas tensiones, dialogamos con referentes en el tema y con activistas por los derechos de las personas LGBTIQ: entrevistamos a Dora Barrancos, a María Rachid, a Paula Carri y a activistas de las organizaciones FALGBT, 100\% Diversidad y Derechos, SIGLA, La Fulana y OTRANS La Plata. En estos intercambios indagamos si Internet podría funcionar como medio para una comunicación igualitaria y no discriminatoria, si se debiera impulsar una ley que regule los contenidos en Internet y qué características debería tener. A los activistas también les preguntamos si alguna vez habían sido víctimas de discriminación o violencia en Internet, cómo reaccionaron, cuál era la postura de la organización a la que pertenecen y qué soluciones propondrían.

Sabemos que históricamente las organizaciones por la promoción y la defensa de los derechos de las personas LGBTIQ han luchado a través de distintas estrategias de visibilización y sensibilización cultural en contra de las formas de irrespeto cultural en que material y simbólicamente vulnerabilizan a este sector. De este modo, buscan transformar las condiciones macro y micro sociales que se sostienen sobre estereotipos 
y prejuicios, sobre órdenes sexo-genéricos asimétricos y desiguales, sobre binarismos excluyentes y normalizadores y sobre la reificación y banalización de las corporalidades, subjetividades, identidades y prácticas deseantes de los sujetos subalternizados LGBTIQ. A raíz de ello, demandan que el Estado argentino revise las legislaciones antidiscriminatorias vigentes a fin de proteger a este colectivo dado que no existen leyes nacionales que les de amparo ante un despido o una amenaza motivada por su orientación sexoafectiva o por su identidad o expresión de género. Y como ya dijimos, en la web tampoco existen protecciones legales contra la discriminación motivada por orientación sexoafectiva e identidad y expresión de género.

En este sentido, Dora Barrancos advierte que "en Internet vale todo". Reconoce que Internet puede y no puede funcionar como un espacio propicio para un trato igualitario y una comunicación no sexista y homofóbica porque allí confluyen causas justas con otras injustas, donde pueden forjarse relaciones de fraternidad y sororidad y a la vez prácticas de discriminación. Observa que allí circulan contenidos discriminatorios y que se debe actuar para frenarlos. Dice que "las situaciones de violencia en Internet solo se pueden ir resolviendo en la medida que haya una suerte de ejercicio de supervisión por parte de las agencias por los derechos". Pero Internet es inabarcable y por ello las organizaciones y las personas de la sociedad civil deben estar alerta y en sintonía para vigilar los espacios y las manifestaciones que sean indecentes con los derechos humanos con el fin de denunciar las voces que busquen humillar a las personas. Sin embargo, sabe que esta es una tarea compleja dado que hay discursos xenófobos, clasistas y homofóbicos que se mimetizan y que pasan desapercibidos. Paralelamente, observa que hay manifestaciones neo nazis así como personas con pensamientos muy reaccionarios y conservadores que "se sienten agredidas cuando hay mucha libertad" dado que los avances de derechos para un grupo los implican de forma negativa.

Barrancos cree que es fundamental la actualización de la Ley Antidiscriminatoria así como todas las normas que conmemoran y garantizan los derechos de la ciudadanía. Pero apunta que "el formato legal no quiere decir que se interrumpan los flujos perversos, homofóbicos, transfóbicos en la sociedad”. Sostiene que las leyes van fraguando y minando los sentidos simbólicos y que deben tomarse diferentes medidas para forjar nuevos sentidos. No obstante, para ella "hay algunas [medidas] que parecen que no son inmediatas pero que efectivamente si no las hacemos inmediatamente vamos a correr más riesgos”. Cree que antes que pensar sobre Internet, 
es fundamental y hasta más sencillo trabajar sobre la educación desde el nivel inicial hasta el nivel secundario para que de modo riguroso y sistemático circulen distintas fórmulas de igualación y de denuncia de la violencia. Deben instalarse mecanismos cotidianos de veeduría en las mismas escuelas, para que los estudiantes se informen y se formen en estos nuevos sentidos.

Por otro lado, no deposita su aspiración transformadora en la sociabilidad del hogar porque cree que allí se mantienen formas canónicas de la diferencia sexual, de la diferencia de géneros, de las expectativas y roles de género y la normatividad heterosexual. Sentencia que "las familias son muy reproductoras del cóncavo viejo". Afortunadamente, percibe que con la ley de matrimonio se empezó a disolver el sólido imaginario denostativo, humillante y hostil en el núcleo familiar. "La hegemonía heterosexista normativa se quebró [dado que] la autorización legal ha minado fuertemente las características simbólicas de base de las propias familias". Y si bien aún hay quienes resisten a los cambios, apuesta a que estos nuevos sentidos sigan fraguando.

Por su parte, María Rachid ve que los cambios dados a raíz de los avances legislativos en materia de reconocimiento de los derechos de las personas LGBTIQ son positivos. A pesar de esto, piensa que "lo que resta es la batalla cultural que hay que dar para convertir esta igualdad jurídica en igualdad real”. Al igual que Barrancos, cree que es central el trabajo desde la educación pero también a través de los medios de comunicación, de las políticas culturales $\mathrm{y}$, en casos extremos, de políticas públicas de acciones afirmativas. Valora la necesidad de visibilizar distintas voces en los medios y abordar contenidos sobre diversidad sexual en la educación, aunque dice que encuentra resistencias en las editoriales que están ligadas a la jerarquía de la Iglesia católica.

En este orden de cosas, dice que Internet puede servir como un medio de comunicación no homofóbica e igualitaria. Observa que:

\footnotetext{
Internet es un medio de comunicación fundamental. Es un medio de comunicación que genera y posibilita mucha participación. Nosotros consideramos que eso es positivo, pero que también hay que regularlo como cualquier otro medio. Internet es una herramienta que puede ser utilizada para algo bueno y que puede ser utilizada para algo malo, entonces tiene que tener su regulación, como tiene el resto de los medios de comunicación, para que no sea utilizada para agredir, para insultar, para humillar, para estereotipar.
} 
Al hablar de la propuesta de ley para actualizar la Ley Antidiscriminatoria que contenía un apartado para regular los contenidos discriminatorios en la web, sostiene que:

La regulación por supuesto tiene que tener cuidado de no coartar la libertad de expresión, pero los derechos de uno terminan donde empiezan los derechos de los otros y, por lo tanto, la libertad de expresión es un derecho muy importante pero que también debemos cuidar que no sea utilizado para generar daño.

Cree que es importante que se actualice la ley para prevenir la discriminación de modo que los portales de Internet tengan que informar a los usuarios de que discriminar es un hecho ilícito y así no se genere daño a otras personas. Agrega que:

En cualquier medio de comunicación está regulado el tema de los daños, el tema de la injuria, el tema de las calumnias, y en Internet debe pasar lo mismo. En realidad nosotros entendemos [Internet] que ya está regulado. Una regulación más específica ayudaría a por ejemplo a los portales a PREVENIR la discriminación, porque el resultado de la discriminación ya está regulado en el Código Civil; los daños existen, se puede hacer un [juicio por] daños y perjuicios, se puede reclamar, se pueden hacer muchas cosas. Pero también se puede hacer una regulación para prevenir esos actos discriminatorios.

Para Rachid, "los ataques discriminatorios en Internet son PERMANENTES, constantes y muy preocupantes". A ella le ocurrió que la atacaron por su orientación sexual y su tamaño a través de las redes. Dice que "hay determinados grupos que no les gusta tu opinión y entonces te atacan y utilizan cualquier cosa para atacarte". Por ello piensa que es fundamental que se le dé tratamiento cuanto antes al proyecto de ley de las organizaciones LGBTIQ, aunque ve que hay legisladores que se ocupan de obstaculizar este proceso. Entretanto, la solución que propone consiste en eliminar los discursos discriminatorios para no darles mayor difusión y presentar una denuncia en el INADI o hacer un juicio por daños o perjuicios si los perpetradores son personas que se puedan identificar con nombre y apellido y si no se ocultan detrás de identidades falsas.

Paula Carri, responsable de la Plataforma por una Internet libre de Discriminación del INADI, ve que se necesita modificar la norma sobre la penalización de actos discriminatorios para que abarque la regulación de los contenidos que circulan por la web. Afirma que la regulación no es un modo de cercenar sino que es una manera para que todos se puedan expresar. Si a una persona se la discrimina en un espacio, lo 
está expulsando de ese ámbito. Por ejemplo, en los blogs o sitios de noticias, cuando se ataca a determinados grupos como las personas LGBTIQ, dice que lo que se hace es expulsarlos. Por lo tanto, se deben tomar medidas o aplicar reglamentos o condiciones de uso para garantizar la inclusión de todas las personas.

Carri nos informa que la Plataforma tiene el objetivo de preservar Internet como un espacio libre de discriminación. Nace a raíz de un incremento de denuncias recibidas en el INADI en 2009 y 2010 por hechos de discriminación en Internet para atender esos casos con mayor celeridad y dar una respuesta específica según las características propias del entorno, como la rapidez con la que se propagan los contenidos y la masificación que tienen. Para ella es importante abordar esos casos ni bien se producen para evitar que se difundan y que perjudiquen a las víctimas. Agrega que la actividad de la Plataforma consiste no solo en atender las denuncias de los ciudadanos sino también en generar conciencia para prevenir los actos discriminatorios y educar sobre los usos responsables de Internet. Asimismo, están en contacto con empresas como Facebook y Twitter para que desarrollen y mejoren sus condiciones de uso y las opciones para reportar perfiles y contenidos y para proteger a los usuarios ante los discursos de odio.

Hoy en día reciben aproximadamente 860 denuncias anuales por discriminación, aunque su contenido varía según la época dado que, según ella, "Internet es un espejo de las agresiones de afuera". Dice que en el contexto de mundiales de fútbol, se reciben más denuncias sobre abusos en foros deportivos o en épocas de manifestaciones sociales, por condición social y xenofobia. También recibió denuncias por discriminación contra personas LGBTIQ por acosos, posteos y por fotografías adulteradas. Cuenta que incluso trabajaron sobre páginas y blogs donde se promueve la diversidad sexual y las experiencias de familias diversas, donde apareció lo que denomina como "acosadores seriales" o "trolls seriales", quienes no participaban para cuestionar los contenidos, sino que buscaban agredir. En ese caso, las medidas que se tomaron fueron gestionar las denuncias y reportar a esos usuarios. Observa que recientemente vio manifestaciones neo nazis que a la vez eran homofóbicas.

En este sentido, desde la Plataforma ve que hay mareas que van mutando y que atacan distintos temas según la coyuntura de actualidad. Y a la vez hay cruces entre la virtualidad y no virtualidad, motivo por el cual se deben emplear diferentes herramientas para resolver cada caso. Primero, lo primordial es tomar las precauciones necesarias: no compartir contraseñas, revisar la configuración de privacidad de las cuentas y no participar en páginas donde no existan condiciones de uso que se 
pronuncien sobre los discursos de odio o que no tenga herramientas para denunciar contenidos abusivos y discriminatorios. En caso de ser víctima o testigo de estos hechos, sugiere elevar la denuncia dentro de la misma página donde transcurrió, tomar capturas o fotos y anotar la fecha, usuario y la mayor cantidad de información que sea posible. Recomienda no contestar a los agresores sino reportarlos y bloquearlos. Luego, no sobredimensionar la situación pero tampoco restarle importancia. Y en caso de que el acto persista o que no se haya resuelto en el interior del sitio, recomienda contactar al INADI. $^{70} \mathrm{Si}$ bien los casos de discriminación generalmente cesan con las primeras denuncias, puede suceder que se gestione la baja de un sitio o de un contenido pero que inmediatamente se publique uno nuevo. Y si se percibe que alguien está empecinado con una persona se puede acudir a la fiscalía de Delitos Informáticos o a las autoridades policiales.

Los activistas entrevistados opinan que la actualización de la Ley Antidiscriminatoria es necesaria en la medida de que protegería a los usuarios más vulnerados. Desde SIGLA, Participante A se expresa a favor de que se regule la comunicación en Internet y de que se tome a la discriminación por orientación sexual e identidad de género como agravantes. En este sentido, cree que se sentiría más seguro si supiera que tiene la posibilidad de realizar una denuncia por amenazas recibidas a través de Internet. Cree que "abrir una puerta más para las comunicaciones parece ser que es también una puerta más para que te insulten y te ataquen”. Por sus observaciones y sus experiencias personales en las que desconocidos lo atacaron por Facebook por subir fotos con su pareja, cree que los administradores del sitio no eliminan páginas o contenidos con material ofensivo y violento sobre personas LGBTIQ con el pretexto de que no infringen sus normas comunitarias. Más aún, ve que hay usuarios denuncian las fotos de parejas homosexuales que se besan porque para ellos su contenido es obsceno o pornográfico, y Facebook procede a revisar y a eliminar tales imágenes. Por eso recomienda ser selectivos a la hora de aceptar "amigos" en Facebook, eliminar y bloquear los contenidos ofensivos y en todo caso borrar y bloquear a los usuarios que agreden. También propone asesorarse legalmente y escalar la denuncia si se siente que se trata de una amenaza que se puede concretar en el plano físico. Alerta que no hay que desestimar las consecuencias materiales, psicológicas y emocionales de esos comentarios discriminatorios, sobre todo entre menores de edad, ya que siente que ellos

\footnotetext{
${ }^{70}$ Se los puede contactar a través del correo electrónico plataforma@inadi.gob.ar.
} 
tienen menos herramientas para hacer frente a tales circunstancias; luego recuerda los casos de dos adolescentes estadounidenses que se suicidaron tras sufrir de acosos homofóbicos virtuales.

Las entrevistadas de La Fulana también se quejan de Facebook, red que usan con gran frecuencia para llevar adelante su activismo porque les permite llegar a muchas personas con un costo menor que si tuviesen que hacer campañas en la vía pública. Pese a su presencia en las redes, hasta el momento de la entrevista, dicen que nunca se las discriminó por su orientación sexual. ${ }^{71}$ Sin embargo, dos integrantes fueron echadas de una radio por Internet donde conducían un programa por sus publicaciones en Facebook. Recuerdan que subieron fotos y videos con sus torsos desnudos o en bóxer en el marco de eventos que habían organizado y que los dueños de la radio dijeron que las imágenes iban en contra de las reglas básicas de pudor, las buenas formas, la moral y el sentido común. Participante B cuenta que:

[Nos dijeron] que esa no era la manera [de manifestarnos] y que no tenía que ver con ninguna lucha ponerse en tetas. Lo cual se lo discutimos lógicamente porque creemos que tiene que ver con la lucha del feminismo, con la lucha de la diversidad. Apropiarse del cuerpo y no solamente apropiarse sino que exponerlo, de defender mi identidad, de empoderar mi identidad y mi forma...

Además justamente había muchos cuerpos no hegemónicos en esas fotos y en ese video, y ahí nos echaron. Decidieron que no hacíamos más el programa.

Para ellas el despido fue injusto ya que las imágenes que habían publicado formaban parte de una campaña afirmativa de promoción de los derechos de los disidentes sexogenéricos y que no mostraban nada fuera de lo común.

Al mismo tiempo, observan que esta red social suele censurar los pezones de fotos de pechos femeninos o las borra directamente, algo que no sucede con los contenidos discriminatorios y violentos. ${ }^{72}$ Una vez más, recuperamos la voz de Participante B:

\footnotetext{
71 Luego de la protesta del "tetazo" del 7 de febrero de 2017, la activista Participante B publicó en su muro de Facebook las capturas de los comentarios que le enviaron desconocidos por mensaje privado a partir de su aparición en un programa de televisión que transmitía el evento. La contactamos para indagar sobre el hecho y dijo que no se la discriminó por su orientación sexual sino por su tamaño y por su expresión de género. Finalmente, vimos que Facebook bloqueó su cuenta por cinco días a raíz de las quejas de quienes figuraban en las capturas de pantalla.

${ }^{72}$ Sobre las lógicas de moderación y eliminación de contenidos de Facebook, un artículo de La Nación se esgrime que la tarea del moderador es un "rompecabezas" y que "Facebook estima que "la gente usa un lenguaje violento para expresar en línea su frustración' y que 'haciéndolo, se sienten seguros'. La red
} 
[En] Facebook cuando vos denunciás una teta, inmediatamente la borran, pero cuando denunciás una página que es violenta no la borran inmediatamente. Tenés que hacer MUCHAS denuncias y REITERAR las denuncias hasta que la borran. Facebook que decide cómo se le canta el orto.

Las integrantes de esta organización actúan de manera colectiva con otros activistas cuando alguien encuentra páginas violentas para solicitar que su eliminación. Dicen que en las redes se sienten más protegidas por sus pares y contactos que en la calle, donde uno está más solo y hay más impunidad. Participante B lo sintetiza con estas palabras:

Las redes sociales tienen un planteo distinto a lo que tiene que son en términos generales los comentarios abajo de las notas de los diarios, [donde] la gente es profundamente anónima. Yo creo que, al contrario, la vía pública en ese sentido te da mucho más anonimato. No está tu mamá, tu hermana, tu tío, tu perro, tu amigo, tu amiga mirándote cómo le gritás a las dos lesbianas: "Te falta una buena pija”. En cambio, si vos lo posteás en Facebook, sí.

Participante $\mathrm{C}$, de la misma agrupación, agrega:

La soledad que tiene la lesbiana cuando está en la calle no es la misma que cuando está en Facebook. [...] A la primera [ocasión] que te bardeen, vas a tener un montón de contactos que van a salir a respaldarte. Las redes generan esos lazos [pero] si vos estás sola en la calle caminando y te insultan, probablemente nadie va a saltar a decirle al agresor: “¿Qué la bardeás?”

Ambas perciben que en Internet hay una "cultura del escrache", que consiste en señalar y exponer a los usuarios y las páginas con contenidos discriminatorios y en ponerse de acuerdo entre varios contactos para denunciarlas a través de las herramientas que provee la plataforma.

Participante D, que forma parte de la organización de mujeres trans OTRANS La Plata, alude a diferentes tipos de prácticas que la afectan cuando usa su cuenta personal y la página de la agrupación en Facebook. Estas incluyen comentarios discriminatorios que recibe por su identidad de género, como "vos no sos una mujer, sos un hombre" y "vos nunca vas a tener hijos"; y también se siente discriminada por la

social más célebre del planeta asume así un papel de válvula de escape”. Ver: CORRADINI, L. (23 de mayo 2017) "Al descubierto: revelan las reglas de Facebook sobre sexo y violencia", La Nación. Disponible en http://www.lanacion.com.ar/2026451-al-descubierto-revelan-las-reglas-de-facebook-sobresexo-y-violencia [Consultado el 26 de mayo 2017] 
forma en que los contactos dejan de hablarle tras saber que ella es una mujer trans y por los usuarios de las redes que le realizan insinuaciones e invitaciones sexuales. Dice que además la han discriminado por ser extranjera y le han enviado mensajes como “¿Por qué no te vas de acá?”. Ella siente que estas prácticas son violentas y más le molesta que la mayoría de los discursos de odio provengan de personas conocidas, de compañeros de trabajo y de sus alumnos.

Participante E es otra una mujer trans e integra la FALGBT. Indica que debe existir una ley para perseguir y combatir estos discursos de odio ya que siente que en Internet se generan muchos contenidos discriminatorios que no tienen ningún tipo de control porque no es un ámbito alcanzado por la ley. Dice que los discursos discriminatorios y violentos de la virtualidad tienen los mismos efectos que en la esfera no virtual y por ello se deben tomar medidas urgentes porque "todavía falta dar una batalla cultural para poder generar una conciencia más amplia sobre todos estos derechos". Para ella, es necesario:

Tratar de generar sensibilidad y concientización sobre los derechos, sobre el respeto hacia la diversidad sexual y la convivencia en diversidad. Creo que la herramienta principal es la comunicación porque mucha gente reproduce lo que los medios de comunicación transmiten y no lo analizan. Los medios por supuesto generan opinión pública e ideología. Entonces, es necesario también formar espacios de comunicación donde una pueda transmitir información contrahegemónica, contra estos medios que en general son peyorativos. La información [en esos medios] es peyorativa, es estigmatizante y ridiculizadora de la diversidad sexual.

Ella recibió comentarios vulgares e insultantes por Facebook que desacreditaban su expresión de género y la denostaban como mujer trans. Especialmente recibió comentarios de esta índole cuando publicaba contenidos relacionados con temas de alta sensibilidad social, como por ejemplo sobre las infancias trans. Relata que anteriormente esta red social no era amigable con las personas trans porque había implementado una política de nombres reales y quienes aún no habían realizado su cambio registral no podían dar pruebas de su identidad y sus nombres autopercibidos. Pero gracias a gestiones satisfactorias con su organización, cesó con esa política y además ahora admite categorías sobre diversidad. 
En Facebook, al igual que las integrantes de La Fulana, denuncia las páginas ofensivas y solicita la colaboración de muchas personas. Sobre la respuesta del medio alega que: "Facebook primero te dice 'No, no pasa nada' y después de que le llegan miles de denuncias dice 'Bueno, sí, pasó algo'”. Gracias a una de esas páginas encontró imágenes de una campaña contra las familias homomaternales y homoparentales de una institución educativa porteña, en cuyo interior se habían colgado carteles gigantes que decían "la vida se hace entre hombre y mujer" y que eso era lo normal. Respecto a su cuenta personal, dice que es un espacio abierto al debate pero cree que hay veces en las que no se puede dialogar con los usuarios que promueven ideologías discriminatorias. Por ello prefiere no entrar en su lógica de violencia y eliminarlos y bloquearlos. "Si alguien tiene algún problema conmigo me lo puede plantear pero no con insultos", concluye.

Participante F es abogada y miembro de 100\% Diversidad y Derechos y, al igual que la participante anterior, cree que no conviene responder a los agresores. Cuenta que en su organización usan Facebook, Twitter y un blog, y que en esos espacios reciben comentarios de diversa índole. A partir de un caso puntual, se explaya sobre las características de esos textos:

\begin{abstract}
Ayer hicimos un posteo relacionado con el ballotage [tras las elecciones presidenciales de octubre de 2015] sentando una posición, que tiene que ver con el reconocimiento de derechos. Nosotros somos una agrupación política no partidaria (hacemos política, pero no es política partidaria). Entendimos que en este momento teníamos que pronunciarnos. Obviamente, la catarata de respuestas fue inmensa. Las que eran meros insultos, las borramos. Lo que se puede argumentar se argumenta. Queremos transmitir nuestra idea y que se genere un intercambio en tanto y en cuanto las respuestas no sean violentas. Nos ha pasado en un posteo del blog que un comentario sea "negro puto", por ejemplo. Y eso se borró. Ahora, si es "no estoy de acuerdo", para problematizar algo, obviamente se deja porque estamos discutiendo ideas y no nos creemos dueños de ninguna verdad. Lo que sí, predicamos con el ejemplo de la no discriminación, de la no violencia.
\end{abstract}

Con respecto a la revisión de la Ley Antidiscriminatoria, cree que una ley que regule Internet no representa una amenaza a la libertad de expresión porque el derecho a no ser agredido debe ser más importante que tener la libertad de expresarse. No 
obstante, piensa que legislar sobre la web es un asunto difícil dado que las fronteras nacionales se desdibujan con mucha facilidad y se pueden sobrepasar sin importar las pautas legales. En sus palabras: “en Argentina podés poner leyes durísimas pero Internet es una plataforma virtual mundial". Dice que las páginas web pueden migrar de un dominio .com.ar a uno .net o .com y burlar cualquier normativa vigente en el país. Por lo tanto, cree que la batalla no se debe dar tanto desde el plano de lo legal sino más bien desde un cambio cultural. Por último, valora la importancia de que las organizaciones LGBTIQ generen talleres de empoderamiento y campañas de sensibilización y que habiliten el diálogo y la discusión de ideas.

En esto coincide Bimbi, que cuando lo entrevistamos para hablar sobre su blog en un contexto donde se discutía sobre el proyecto de ley de la FALGBT indicó que no estaba de acuerdo con adoptar medidas punitivas que criminalizaran la homofobia. En su lugar, propone asignarle al Estado un rol de promotor de derechos ya que para él los prejuicios no se pueden revertir con prisión sino que ello solo puede lograrse a largo plazo a través de acciones socioeducativas. En este aspecto, señala que los proyectos de ley que se unificaron en el expediente 9064-D-14 no pueden resolver la problemática de fondo ni transformar los prejuicios que están arraigados en una sociedad. Opina: “yo no creo que la solución pase por el derecho penal, ni para la homofobia ni para el racismo ni para el antisemitismo". Por ejemplo, en lo que refiere a los crímenes de odio contra personas LGBTIQ, está de acuerdo con que se considere la motivación homofóbica como agravante, pero ello no debería traducirse en un aumento de la pena sino en medidas socioeducativas. Lo mismo con el discurso de odio: se opone a que se penalice la discriminación homofóbica ya que no quiere que nadie vaya preso por llamarlo "puto de mierda" y además porque, en el caso de Brasil, esto solo avalaría a la policía a seguir persiguiendo a los jóvenes pobres de las favelas y no a las personas de clase media o alta.

Por otra parte, dice que la Ley de Matrimonio Igualitario, la Ley de Identidad de Género, la Ley de Creación del Programa Nacional de Educación Sexual Integral y las políticas positivas sirvieron más para combatir el prejuicio y cambiar la manera de pensar de la gente que cualquier norma penal. Por eso no está de acuerdo con los aspectos penales del proyecto de ley en cuestión y piensa que el apartado de Internet le parece menos preciso de lo que plantearon los medios. Sin embargo, cree que el proyecto es muy bueno porque abarca políticas de educación, de salud, de prevención de la discriminación en el deporte y en el trabajo, además de incorporar el principio de 
inversión de la carga de la prueba para defenderse en materia civil. Entretanto, apuesta al intercambio de ideas entre las personas tal como dice que hace en su blog.

Como se puede apreciar, los entrevistados están a favor de la actualización de la Ley Antidiscriminatoria para que contemple la discriminación por orientación sexoafectiva e identidad y expresión de género. Con respecto a la regulación de los contenidos discriminatorios en la web, hubo una tendencia a ponderar la necesidad de que haya criterios claros y precisos tanto en las normativas como en el interior de las plataformas para que se gestionen las denuncias sin mediar arbitrariedades. Asimismo, no perciben que ello pueda obturar la libertad de expresión porque debería primar el derecho a una vida libre de discriminación. Dicen que en todo caso los actos discriminatorios afectan el derecho a la libertad de expresión de las víctimas porque esos ataques pueden conducir a que dejen de participar en determinados espacios o evitar publicar ciertos contenidos para no exponerse al agravio. De todas maneras, varios entrevistados apuestan a tomar medidas socioeducativas para dar una "batalla cultural" con el fin de contrarrestar los prejuicios que están arraigados en la sociedad. Además, quienes subrayan la importancia de generar las condiciones que habiliten una transformación social destacan las dificultades jurídicas y prácticas de legislar sobre Internet ya sea por el alcance de las reglas y por la dimensión universal que tiene la World Wide Web.

Por otra parte, vemos que la red social más utilizada por las agrupaciones es Facebook, donde observan que se censuran fotos con pezones o con parejas del mismo sexo por considerarlas obscenas pero no se da lugar a denuncias por materiales peyorativos homofóbicos objetando que no incumplen las normas de la plataforma. Por ello, los activistas adoptan medidas preventivas, como por ejemplo ser selectivos a la hora de aceptar nuevos "amigos", no responder a los textos y los usuarios ofensivos, eliminarlos, bloquearlos y reportarlos y también solicitar la intervención de sus pares para denunciar entre muchas personas aquellas páginas y usuarios que publican contenidos discriminatorios con el fin de demandar respuestas del medio. Mientras algunos hablan de que en las redes existe un marco de protección que está dado por los contactos y conocidos en común, otros sienten que el anonimato puede despersonalizar la comunicación y hacer que la gente se anime a decir lo que se les ocurra a pesar de que ello pueda disminuir, restringir o menoscabar los derechos de las personas.

A modo de síntesis, los entrevistados ven que circulan comentarios discriminatorios en las redes sociales, en los blogs y en las páginas de los diarios en sus 
versiones digitales. En los últimos vale todo, pero en los otros uno puede tener más control sobre qué y quién forma parte de su círculo de contactos y se pueden borrar, bloquear y reportar los contenidos o a los usuarios no deseados. Estas operaciones, al igual que las prácticas de contestación de los blogs, representan modos de resistir a los intentos de vulnerabilización. A la vez, permiten transformar a la web y a sus cuentas personales en espacios habitables para sí mismos y para aquellos con quienes deciden compartirlo. Los entrevistados notan que los mecanismos actuales de regulación de las plataformas son funcionales al reforzamiento de los mandatos normativos del orden sexo-genérico existente a través la su actividad de administración y moderación por el cual eliminan (o no eliminan) de determinadas páginas y textos. A pesar de ello, no todos los activistas sienten que se los haya atacado personalmente por su orientación sexual, aunque hubo hombres gays y mujeres trans con quienes dialogamos que sí pudieron dar testimonio de experiencias en las que se los maltrató por su orientación sexual y su identidad de género.

En consecuencia, identificamos que hay un continuum de discriminación y violencia que se sustenta sobre una cisheterosexualidad compulsiva, normativa y estigmatizante de la disidencia sexo-genérica. La misma impregna las redes a través de los usos que se le dan a fin de ofender y marginar a los sectores vulnerabilizados para perpetuar su desigualación. Sin más, esto consiste en la digitalización de las modalidades discriminatorias de antaño que se reconfiguran y se resignifican en nuevos formatos más o menos explícitos de discriminación, como la apertura de páginas orientadas a acosar a una o a varias personas con motivo de su género o su orientación sexual, la publicación de textos denigratorios desde cuentas personales o la creación de perfiles falsos para lanzar ataques anónimos. Estas prácticas coexisten con otras del cotidiano, como por ejemplo acoso escolar homobilesbotransfóbico y la desidia de las autoridades para proteger los derechos de los ciudadanos LGBTIQ.

Por último, vemos que mientras se discute sobre la actualización de la Ley Antidiscriminatoria, acontecen prácticas que violentan a las personas LGBTIQ y que coartan su participación y los excluyen de los entornos virtuales, tal como históricamente se ha hecho con ellos en el espacio público. En este sentido, creemos que es indispensable que las organizaciones estatales y aquellas de la sociedad civil generen instancias de formación, concientización y sensibilización sobre cómo actuar ante un acto discriminatorio en Internet y sobre cómo desandar las heteronormalizaciones y sus consecuencias. Más importante será generar políticas públicas inclusivas e igualitarias 
que tomen como protagonistas a los sectores vulnerabilizados a fin de atender sus intereses, sus necesidades y sus problemáticas. Los testimonios de las personas aquí entrevistadas nos muestran diferentes posturas y posibles soluciones para reparar, prevenir y erradicar estos tipos de violencias y nos ayudan a reconocer las posibles prácticas de resistencia y subversión similares a las que encontramos a lo largo de nuestro análisis en los blogs y en los diálogos con sus responsables.

\subsubsection{Conclusiones provisorias}

En las páginas anteriores observamos los sentidos que otorgan Dema y Bimbi a los espacios que tienen a cargo, a los intercambios que allí transcurren y a las maneras que tienen de intervenir en ellos. A partir de las entrevistas y de los corpus abarcados, vimos que Dema cumple un rol de moderadora abstencionista, ya que participa en BP en solo una ocasión y procura no eliminar comentarios. En el caso de Bimbi, cumple un lugar de mediador y suele tener una participación más activa para leer y responder comentarios. A pesar de no borrar contenidos, delega esta función a los moderadores de los blogs de TN. Así, podemos indicar que el rol que ocupa Bimbi se asemeja al de los moderadores de debates o paneles, donde se busca ser imparcial y dar lugar a las voces de todos. En cambio, en su afán de preservar principalmente los derechos de las personas LGBTIQ, el lugar de Dema es más propio de los moderadores de la web ya que su cuenta está configurada para poder eliminar mensajes y bloquear usuarios y hace uso de esta habilitación. Pero por otro lado, podríamos pensar que Bimbi actúa como activista a partir de sus intervenciones, mientras que el silencio de Dema puede ser visto como una toma de postura que en su afán por ser neutral puede ser funcional a la marginación de la comunidad homosexual.

Es notorio que en ambos sitios predomina el interés de que "haya debate" en tanto los blogs son percibidos como foros de opinión. Esto se condice con las características propias de las situaciones de debate del espacio público no digital que dio lugar a la terminología que hoy se emplea para aludir a los espacios de intercambio como los foros y al lugar que ocupan sus participantes, como el caso del moderador. Por ello, son lugares propicios para el ejercicio de la ciudadanía y para el fortalecimiento de los sistemas democráticos a través de la garantía del derecho a la comunicación y a la libertad de expresión, pero también al derecho de gozar una vida libre de 
discriminación. Vemos que tanto para Bimbi como para Dema la dificultad principal radica en la (in)determinación del límite entre un derecho y otro, en la dificultad por discernir dónde trazar la línea divisoria entre la libertad de expresión y el agravio y en la incertidumbre por cómo transitar las tensiones entre la libertad a expresarse y la censura.

Ante este dilema, conversamos con referentes en el tema y con activistas que al igual que Bimbi forman parte de organizaciones LGBTIQ. Identificamos que defendían la necesidad de actualizar la actual ley contra la discriminación para que abarque aquellas prácticas motivadas por odio contra las personas LGBTIQ y para que se regulen los contenidos que circulan por la web con el fin de garantizar el goce de sus derechos. Reconocieron que en las redes circulan contenidos discriminatorios que son peyorativos con los disidentes sexo-genéricos y que tienen continuidad con otras fórmulas violentas que ven por fuera de la web. Argumentaron sobre la importancia de acompañar esta medida con tareas de vigilia ciudadana y con políticas socioculturales y educativas para desarraigar los pilares sobre los que se sustenta y se fundamenta la cisheterosexualidad obligatoria que estigmatiza y margina a aquel que construye como diferente. A la vez, admiten que las denuncias que han hecho por discriminación en las redes no siempre se resolvieron de manera exitosa para la comunidad dado que los gestores de los espacios no disponen de mecanismos claros de identificación y erradicación de los discursos de odio. Esta desregulación de los espacios lleva a habilitar la difusión de voces adversas sobre las personas LGBTIQ y a que se retrotraiga su participación en los ámbitos donde perciben o sienten que son o podrían llegar a ser víctimas de acosos, burlas, humillaciones e insultos, entre otras. Para protegerse de estos contenidos degradantes denuncian a sus atacantes utilizando las herramientas internas de las plataformas para eliminar, bloquear y reportar los contenidos, usuarios y páginas que intenten menoscabar sus derechos. Cuando las denuncias por las vías formales son desoídas, construyen vínculos de solidaridad y cooperación con sus pares y acuden a estrategias de escrache y de denuncia grupal para aumentar el alcance de su protesta y para darle más visibilidad. ${ }^{73}$

En este sentido, Margarita Martínez (2016) observa que los entornos virtuales ampliaron el campo de batalla política y son de hecho espacios de intervención

\footnotetext{
${ }^{73}$ Debería analizarse en futuras investigaciones si estas prácticas digitales guardan similitudes con las acciones de los activistas en el espacio público no digital en respuesta a procesos que sienten que son injustos, como hicieron con el "tortazo" frente al bar La Biela y el "besazo" en Constitución.
} 
ciudadana que a la vez son espejo del todo social. Dice que "nos pueden proteger de la violencia, aun si al mismo tiempo la ejercen y perpetúan" (2016: 40). Identifica que las primeras experiencias de comentarios en las plataformas de diarios digitales se escudaron detrás de una suerte de anonimato o seudo anonimato que rápidamente hicieron aparecer la figura de un moderador para arbitrar en dichos intercambios violentos, aunque su rol en las noticias "sensibles" se volvió tan inútil que se optó por cerrar la posibilidad de publicar comentarios. Agrega que las modalidades que adquiere la violencia en Internet quizás sean tales debido a la creencia de que uno allí es impune, que no habrá sanciones o que la misma será tardía o menor. De este modo, las personas que participan en la web crean y validan los mecanismos que censuran las conductas violentas. Pero así también se habilitan operaciones violentas para luchar contra ella, como por ejemplo el escrache colectivo, usualmente legitimado por un ideal de justicia o ajusticiamiento sin mediar reflexión acerca de su utilización como dispositivo de castigo.

Sin embargo, sería menester considerar la posibilidad de que los actos calificables como violentos sean más bien acciones defensivas en pos del mantenimiento de un status quo que se siente que está siendo arrebatado, como sería el caso de los comentaristas que hostigan a las personas LGBTIQ en los blogs en cuestión. $\mathrm{O}$ bien puede que haya quienes busquen conservar y proteger un espacio que se siente como propio y en donde no son bienvenidos los sujetos que lo vuelven menos seguro, como hicieron algunos usuarios agrediendo a otros y al pedir la eliminación de sus comentarios. La construcción de un "otro" como peligroso o violento parece obrar como justificativo de accionares calificables como violentos que son multidireccionales y se orientan a acabar con esa amenaza o con quienes la perpetran. Simultáneamente, la vigilia en defensa de ciertos valores y comunidades genera vínculos colectivos, construyendo y fortaleciendo a un "nosotros" y avalando sus discursos a favor de, o en contra de, quienes sean percibidos como los "otros".

Ahora bien, quiénes son los "otros" y quiénes son los violentos en los dos blogs, como vimos, es una cuestión de perspectiva y depende de los sentidos que allí circulen, de los participantes involucrados en los procesos comunicacionales, de los usos y apropiaciones que se hagan sobre los blogs y de los lugares de poder que ocupen en el entramado cultural. Observamos que el ejercicio de moderación por parte de Dema y de Bimbi está ligado a su interés por intercambiar ideas siempre y cuando no se agravie a las personas LGBTIQ, pero para algunos usuarios esta moderación es excesiva y se 
condice con un ataque a la libertad de expresión y a la libertad de culto. Notamos que estos usuarios perciben que hay continuidades entre los artículos de los blogs y de los multimedios a los que pertenecen, si bien nosotros no identificamos que las mismas existan. Más aún, vemos que los contenidos de los comentarios discriminatorios contra las personas LGBTIQ que se publicaron en BP y en Tx a pesar de la moderación guardan similitudes con las líneas editoriales de Clarín y La Nación dado que tienen una perspectiva cisheterosexista que defiende los modelos tradicionales de matrimonio y de familia, que resguarda los binarismos de género y que sostiene las asimetrías del orden sexo-genérico que es denostativo con respecto a los sujetos queer.

En pocas palabras, en estos cuatro medios circulan sentidos que obturan la integración real de las personas LGBTIQ y que, con distintas estrategias discursivas, abogan por una no-discriminación a medias. En los blogs hay una tendencia a discriminar a las personas LGBTIQ sin reconocer que se las está violentando dado que se argumenta que ellas discriminan a las personas heterosexuales y a los creyentes. En BP notamos que más de la mitad de las intervenciones eran violentas, que la mayoría se dirigía a las personas LGBTIQ y a sus aliados, pero que en una cifra cercana también se violentaba a las personas cisheterosexuales. En Tx, a pesar de abordar temáticas de mayor sensibilidad social que en BP, predominaron los intercambios no violentos, tal vez quizás porque la participación de Bimbi era mayor. Allí encontramos comentarios violentos en contra de las personas LGBTIQ y sus aliados, pero muchos menos en contra de quienes no lo eran. Estas violencias parecen surgir como reacción o como manifestación defensiva ante la sensación de amenaza por una posible futura pérdida. En cambio, los dos diarios de tirada nacional, bajo un velo de lo políticamente correcto, se oponen a la discriminación contra las personas LGBTIQ. Sin embargo, mediante el uso de los topoi del humanitarismo, del derecho y del peligro, rechazan el reconocimiento de las leyes que otorgan garantías y derechos a este colectivo, ya que serían discriminatorias para el resto de la sociedad. En sintonía con esto, la fórmula de los blogs de "que haya debate" y de que se publiquen prácticamente todos los comentarios nos ayuda a entender que los "otros" siguen siendo los sujetos queer a pesar de estar en un espacio que perciben que está dirigido a ellos. En suma, todos somos iguales, pero unos son más iguales que otros. 


\section{CONCLUSIONES}

En este escrito analizamos cómo La Nación y Clarín representaban a las personas LGBTIQ a partir de sus líneas editoriales en los editoriales que publicaron entre 2012 y 2015 y a través de la publicación y eliminación de comentarios en los blogs Boquitas pintadas y Tod@s en el mismo período. Para ello recopilamos seis editoriales y 5.095 comentarios publicados, más otros 43 comentarios eliminados que nos facilitó la autora y moderadora de BP y que nos ayudaron a complementar el análisis. Nos aproximamos a nuestro corpus desde la línea de investigación de los estudios culturales latinoamericanos con una perspectiva interdisciplinaria, feminista y queer y luego construimos una estrategia metodológica que era principalmente cualitativa y queer.

En primer lugar nos servimos de las herramientas de la etnografía virtual y del ACD para el análisis de los comentarios con el fin de indagar sobre las representaciones discriminatorias y violentas sobre las personas LGBTIQ en los comentarios publicados en los blogs entre 2012 y 2015 y también para examinar los discursos que resistían a ellas. De este modo, identificamos que los comentaristas disputan y negocian sentidos hegemónicos y contra-hegemónicos sobre diversos asuntos que generalmente guardaban relación con los temas de cada post. En BP primaba la discusión sobre las leyes referidas al matrimonio y a la adopción por parte de parejas del mismo sexo, donde se discutía sobre qué es la familia, qué es el matrimonio y qué es lo mejor para los niños en adopción. En Tx, en cambio, fueron centrales los debates sobre religión y sobre las personas trans, específicamente en lo que compete a la ley que reconoce su identidad autopercibida y a la posibilidad de otorgarle un subsidio a un grupo particular de personas trans.

En ambos vimos que se detentaban nominaciones y predicaciones peyorativas y estigmatizantes de los homosexuales y de las mujeres trans y en algunos textos incluso 
se incorporaron imágenes que ridiculizaban y humillaban a las travestis, además de evidenciarse sesgos discriminatorios por su edad, su clase, su presunta carga seropositiva y su género. En este sentido, se las representa como prostitutas que no aportan nada a la sociedad y esperan que el Estado las mantenga. La demonización de este sector viene de la mano con un repudio generalizado en contra del movimiento político kirchnerista y en contra del lobby gay y su ideología de género, algo que se dice que tendría fin con un nuevo gobierno en 2015. Estos usuarios sobre todo se oponen a la "política de los subsidios", que regala la plata a la gente que no quiere trabajar y les quita dinero a los trabajadores. Denuncian que hay otras prioridades en el país, como atender a jubilados, a niños desnutridos y a discapacitados, así como mejorar la educación, la salud pública y el salario de los docentes y médicos. Ello parece obedecer a un reclamo por un sentimiento de ausencia o abandono estatal, que no se encarga de las vidas de quienes no forman parte de la población LGBTIQ e incluso llegan a proponer disfrazarse para recibir un subsidio o un empleo. Más aún, hay una tendencia a representar a las personas LGBTIQ como seres promiscuos y violentos a los que les gusta victimizarse. Ellos amenazan y ponen en peligro la familia, el matrimonio, los hijos y la sociedad "normal”. Aquí identificamos que los comentarios suscitan viejos demonios populares y ansiedades morales que recaen sobre un chivo expiatorio queer, depositario de rasgos asociados al peligro, a la promiscuidad sexual y a la enfermedad.

Por otra parte, se los acusa de teofóbicos pero sobre todo, de heterofóbicos, por no tolerar a quienes piensan distinto a ellos. Estos términos se complementan con la inversión de la retórica de la inversión o la diferencia, que consiste en colocar a los cisheterosexuales en el lugar de "invertidos", aquel que usualmente le reservaban a quienes no eran cisheterosexuales. Por esta razón, hoy los homosexuales y las personas trans son los nuevos victimarios, que en su afán por velar por sus propios derechos están recibiendo privilegios a costas de las personas que "deciden" no ser como ellos y a quienes les sacan derechos. Es decir que hay una creencia de que el reconocimiento de los derechos de un grupo impacta negativamente en los de los grupos que no se vieron alcanzados por una ley. De este modo, estos nuevos marginales se representan a sí mismos como los excluidos y se apropian del lugar de desigualdad, de marginalidad y de minoridad, lugar desde el cual se perpetúa la desigualación de los sujetos LGBTIQ.

Quienes resisten a todas estas valoraciones lo hacen con contra-argumentos que rechazan los estigmas de enfermedad, perversión y odio que se les atribuyen. Algunas de estas personas se presentaban como sujetos con orientaciones sexoafectivas o 
identidades o expresiones de género no normativas, mientras que unos pocos se distanciaban discursivamente del colectivo para defenderlo. Entre este grupo de personas encontramos a quienes se mostraban cercanos a los valores e ideas que defendían los autores de los artículos, que decían haber leído y entendido el contenido del post e incluso felicitaban a Dema y Bimbi según el caso. Estas personas reconocían las desigualdades a las que se ven sometidas las personas LGBTIQ, argumentando que sus derechos están siendo vulnerados y que merecen ser protegidos; que son víctimas de un sistema que las margina y de un Estado que las abandona. Asimismo, observamos que entre estas prácticas de resistencia, hay comentarios dirigidos a quienes las agreden y que contienen una carga violenta similar o mayor a la primera. Dicho de otro modo, hay una escalada de violencias que deriva en una shitstorm y que podría conducir a satisfacer la premisa de que las personas LGBTIQ son violentas e intolerantes con quienes piensan distinto, si bien notamos que dichas prácticas son en reacción al ataque inicial y por respuesta a la percepción de que hay un sujeto no queer que pone en peligro los derechos alcanzados.

En nuestro análisis de los seis editoriales publicados en las versiones digitales de Clarín y La Nación entre 2012 y 2015, pudimos observar continuidades con los comentarios discriminatorios de los blogs. En La Nación hay un posicionamiento ambiguo y contradictorio sobre las personas homosexuales: mientras se opone a su discriminación, persecución y hostigamiento, expone su rechazo a que puedan contraer matrimonio pero sin negarles la posibilidad de acceder a los mismos derechos y garantías. Paralelamente, y sin ambigüedad alguna, critica la ley de cupo laboral trans porque privilegia a un sector y no cumple con el principio de igualdad; en todo caso, dice que profundiza la desigualdad perjudicando a quien no es trans. Por su parte, el "gran diario argentino" se manifiesta próximo a la fe católica y en contra del subsidio reparatorio para las personas trans del que ya hablamos, así como también se distancia del reconocimiento de la identidad de género de la niña trans Lulú, aunque se hace énfasis en la necesidad de protegerla.

En los editoriales predominan las citas directas e indirectas de discursos que apoyan los argumentos de sus redactores, motivo por el cual hay una tendencia a no darles voz a las personas LGBTIQ: las pocas veces que se las cita es para refutarlas. De este modo, se silencia a las personas con sexualidades, identidades de género y expresiones no normativas, naturalizando la mirada del diario y neutralizando las perspectivas que la contradigan. Discursivamente, ambos medios sostienen posiciones 
que van a favor de la integración social de las personas LGBTIQ pero en detrimento de sus derechos en tanto les niegan el reconocimiento formal de los mismos, como el derecho fundamental a un empleo digno. Así, ignoran sus reivindicaciones y vulneran sus identidades. Aquí las expresiones discriminatorias son menos evidentes que en los comentarios de los blogs. A las mujeres trans se las nombra en masculino, con argumentos centrados en su genitalidad, y se dice que estas personas eligen su identidad de género y su orientación sexual, como si estos conceptos fuesen equivalentes e intercambiables entre sí. ${ }^{74}$ En el caso de las personas trans menores de edad, se invalida su identidad al afirmarse con una mirada paternalista que los adultos deben protegerlas y velar por sus derechos.

Por otro lado, hay una corrección política que pone en primer plano el principio de igualdad y que subraya cómo las leyes o proyectos relacionados con la defensa y promoción de los derechos de los sujetos queer son violatorias de ese principio. Al igual que en los comentarios, se argumenta que se discrimina para privilegiar a las personas LGBTIQ por encima del resto de los ciudadanos. Esta premisa es más una crítica a los gobiernos provinciales y nacionales que estaban de turno en ese entonces y menos a los "beneficiarios" de las leyes, y parte de la idea de que todas las personas tienen las mismas oportunidades a la hora de acceder a la educación o al empleo, por ejemplo. En consecuencia, las políticas editoriales de los diarios tienen otra similitud con los comentarios que se publican en los blogs dado que las demandas del colectivo no se perciben como prioritarias sino como injustas y desigualitarias.

En definitiva, tanto en los diarios como en los blogs se disputa sobre la legitimidad de las leyes y sobre el principio de igualdad y, en consecuencia, sobre una idea de justicia social. Las personas LGBTIQ son ciudadanos de segunda y esto se reitera en los diarios y en los comentarios de los blogs. Hay continuidades ideológicas entre los cuatro espacios en la medida de los discursos que allí aparecen configuran una "otredad" heterosexual que es discriminada por el mero hecho de serlo. Los promotores de tal discriminación heterofóbica son los homosexuales y las mujeres trans, mientras que el gobierno de turno es responsable por operar a su favor. Por este motivo, algunos textos de los que analizamos en los blogs y en los diarios imaginan que el fin de estos males tendrá lugar en 2015 porque perciben que habría un cambio de gestión, con otro partido político no tan afín a las personas LGBTIQ como lo fue el kirchnerista.

\footnotetext{
${ }^{74}$ Recordemos que en todos se habló de las travestis en alusión a las personas trans en general y en masculino, al igual que en los comentarios de los blogs.
} 
Por otra parte, realizamos entrevistas semi-estructuradas para caracterizar y comparar las estrategias de moderación de Dema y Bimbi. De esta forma, pudimos conocer cómo surgieron sus blogs, cómo describirían sus roles en cada espacio y cómo caracterizarían a los usuarios. Y como vimos que los comentaristas les dirigían críticas y denuncias por censura, también optamos por ver cómo interactuaban unos con los otros en los comentarios de cada blog. Notamos que Dema impulsó la creación de su blog, donde intenta llegar a todos los lectores por más que para ella aborde temas que no son los que le interesen al lector promedio de La Nación. Bimbi, por su parte, fue invitado a hacerlo por iniciativa del director de $\mathrm{TN}$ a raíz de sus antecedentes como periodista y activista. Ambos agrupan a los participantes de sus blogs en dos bloques o dos bandos, donde están quienes quieren aportar y discutir ideas y, desde el otro extremo, están quienes entran para "vomitar su odio", como dijo Bimbi. Agregan que esto no es propio de sus blogs sino que lo ven también en los foros de los diarios online. Para Dema la sociedad en general está cargada de odio, aunque Bimbi no coincide con esta afirmación: para él hay un grupo particular de personas que solo busca agredir en Internet. Por ello, ambos creen que es importante que en estos espacios no haya agresión para que no queden tomados por los "odiadores" debido a que alejan a quienes no lo son.

Las acciones que Dema realiza para alcanzar este objetivo consisten en eliminar los comentarios que considera violentos. Ella debe aprobar todos los comentarios que se envían antes de su publicación, aunque admite que puede ser que alguno se le pase por alto por su alta carga laboral y por ser la única responsable del sitio. Además hay que considerar que desde el medio le sugirieron que deje que haya debate. Dema no participa del blog en los años que tomamos: solo intervino una vez para criticar el comentario de una usuaria y "para que nadie se sienta censurado". Por ello calificamos su rol como moderadora abstencionista, aunque este silencio puede obedecer a órdenes del diario de los Mitre. En cambio, Bimbi se corre de la figura del moderador. Dice que delega esta función en los moderadores de TN y que solo pide que se borre o se elimine un comentario cuando es extremo; el criterio aquí también parece difuso. Nos cuenta que todos los comentarios se publican sin mediar filtro alguno. Su participación en su blog es más asidua: cuenta que lee todos los comentarios y que contesta todos los que puede y, como vimos, a veces lo hace para agredir y amenazar a aquellos usuarios que sobrepasan el límite de lo que para él es tolerable. Pensamos que su accionar es propio 
de un moderador que media a través de la palabra ya que para él también es fundamental que haya debate porque le da más visibilidad al blog. Si bien sus roles de moderación son diferentes, vemos que en BP la mitad de los comentarios tipificados eran violentos, pero no ocurría lo mismo en Tx. Por lo tanto, la moderación de Dema no acababa con los procesos violentos en su blog sino que en todo caso parecía habilitarlos más que Bimbi, quien a través de sus intervenciones invitaba al debate sin agresiones para no caer en la "lógica violenta" de los agresores.

Tanto en BP como en Tx hay usuarios que expresan que son discriminados y censurados porque borraron sus comentarios por pensar distinto y alegan que se sustituye la discriminación por género y sexualidad por discriminación religiosa, rechazando las acusaciones de que sus textos son discursos de odio porque para ellos son verdades que se condicen con la realidad. En respuesta, algunos comentaristas acudían a la representación de que los primeros eran enviados por el medio y que eran trolls que solo ingresaban a los blogs para agredir. Notamos que se disputaban no solo los sentidos sobre lo justo y lo injusto, sobre lo bueno y lo malo, o lo verdadero o falso, sino también los sentidos sobre qué constituye una transgresión al derecho a la libertad de expresión. Por ello, para ver cómo resolver la dicotomía entre libertad de expresión y el derecho a la no discriminación, y a la luz de las discusiones recientes con respecto a la actualización de la Ley Antidiscriminatoria de 1988, nos acercamos a las organizaciones OTRANS La Plata, SIGLA, 100\% Diversidad y Derechos, La Fulana y FALGBT para realizar entrevistas semi-estructuradas a sus miembros y con ello validar los conocimientos producidos en el transcurso de la investigación. Paralelamente, y con el mismo fin, dialogamos con Dora Barrancos, María Rachid y Paula Carri del INADI. A estos activistas y referentes les preguntamos si pensaban que Internet podría funcionar como un medio para una comunicación no sexista ni homofóbica y qué pensaban sobre la actualización de la ley en cuestión.

En principio, notamos que la mitad de los entrevistados dijeron haber recibido ataques personales a través de Facebook, especialmente las mujeres trans. Por eso en sus cuentas personales y en las páginas de sus agrupaciones eliminan los comentarios discriminatorios, bloquean a los usuarios violentos y los denuncian dentro de la plataforma. Fueron muy pocos quienes debieron escalar denuncias a las autoridades de personas afectadas que se acercaron a sus organizaciones. Como indica Carri, usualmente los casos de discriminación cesan con las denuncias en las plataformas y no perseveran por fuera de ellas. Para erradicar la discriminación, los entrevistados 
coinciden en la importancia de actualizar la norma antidiscriminatoria para que pase a incluir la discriminación por orientación sexoafectiva, identidad de género y su expresión. Sin embargo, hubo diferentes posicionamientos con respecto a la regulación de contenidos en la web. Los argumentos a favor señalaban que Internet es un medio de comunicación y que como tal debe estar regulado; más aún, ya existen leyes que actúan sobre ella y sobre las que ya nos explayamos. Otro argumento a favor es que la regulación no implica cercenar derechos sino más bien es un modo de asegurar que todos puedan participar por igual en tanto y en cuanto alguien que es hostigado o acosado por la web es más proclive a alejarse de ese o esos sitios. Por lo tanto, eliminar un comentario no deseado es un mecanismo para seguir participando en un espacio.

Los argumentos en contra de la regulación de los contenidos digitales señalaban las dificultades prácticas de regular y sancionar los contenidos discriminatorios en la red por lo inabarcable que es. Otros decían que una medida de ese tipo no modificaría las cuestiones de fondo y que se necesitarían medidas socioeducativas para que haya transformaciones socioculturales. Por esto rechazaron los aspectos punitivos dado que no conducen a generar cambios en el caso de la discriminación. Finalmente, y debemos resaltarlo, ninguno de los entrevistados consideró que la regulación en Internet pueda representar un límite a la libertad de expresión. Como dijeron, éste no es un derecho absoluto y no debe usarse para vulnerar los derechos de otros. A partir de esta premisa podemos pensar que de actualizarse la Ley Antidiscriminatoria para abarcar la discriminación por orientación sexual, identidad y expresión de género, al menos ello podría tener una fuerza expresiva que paulatinamente ayude a prevenir y a erradicar los actos discriminatorios sobre los cuerpos, los deseos, las identidades y las prácticas no normativos. Asimismo, deberían fomentarse medidas socioeducativas para concientizar sobre los usos responsables de Internet, tal como se hace desde la Plataforma por una Internet Libre de Discriminación del INADI.

Con o sin ley, entre los entrevistados hubo una tendencia a valorar la necesidad de luchar contra la discriminación mediante el diálogo no violento y a través de la solicitud de la remoción de los contenidos discriminatorios. Siguiendo lo que dijeron los moderadores sobre los blogs que administran, los espacios quedan tomados por gente que quiere agraviar y que aleja a quienes buscan participar sin agredir a nadie. Sin embargo, en su afán para que haya debate, no pueden percibir que sus lógicas de moderación habilitan la difusión de ideologías cisheterosexistas que promueven la desigualación de las personas LGBTIQ. Los moderadores, por lo tanto, no juegan un rol 
preponderante a la hora de subvertir los sentidos hegemónicos que los diarios ponen en circulación, ya sea porque tienen una agenda atareada y poco tiempo para revisar los comentarios pero sobre todo porque no tienen claro dónde trazar la vara o el límite de lo tolerable.

En definitiva, Internet está lejos de ser un espacio libre de discriminación y esto incide en el derecho a la libertad de expresión de sus usuarios en la medida de que no se sienten seguros al participar en la web. Esta cuestión no es un dato menor: de hecho, es un elemento clave a tener en cuenta en las legislaciones sobre los discursos de odio, la libertad de expresión, la prevención y sanción de actos discriminatorios y la regulación de los contenidos en Internet. Pero es también crucial en las discusiones por la justicia social y el respeto de los derechos humanos para una mejor comprensión de los procesos de lucha por la significación de las palabras y el lugar que en ellos tienen las personas LGBTIQ y dos de los medios hegemónicos del país. Nuestro escrito, transversal a todos estos debates, constituye un aporte original en esas áreas al concluir que los diarios habilitan la existencia y difusión de discursos afines a su política editorial que se plasman en los blogs a través de la participación y publicación de voces que se condicen con una postura mayoritaria que reniega de los derechos consagrados por las personas LGBTIQ; lo hacen en un campo de batalla virtual que por medio de la palabra escrita y otros recursos paralingüísticos revictimiza al colectivo a través de su culpabilización gracias a una apropiación para nada ingenua de la palabra “discriminación" y tras revertir la retórica de la inversión para hacerlo propio de un nuevo grupo cisheterosexual que se atribuye a sí misma una cualidad de minoridad.

En suma, desde sus políticas editoriales, Clarín y La Nación se oponen a los avances en materia legal del colectivo LGBTIQ y dan un tratamiento cuasi-residual a los asuntos relacionados con él. Esto lo afirmamos tras encontrar que en cuatro años publicaron un total de seis editoriales sobre temas relacionados con aquel, de los cuales solamente dos tomaban como tema central algún tópico sobre diversidad sexo-genérica en Argentina: el caso de Lulú y el del cupo laboral. Las personas trans inquietan tanto a los editores de ambos diarios como a los comentaristas del segundo artículo más comentado de nuestro corpus, que pertenece a Tx. El matrimonio entre personas del mismo sexo y la adopción fueron temas comunes entre BP y La Nación, mientras que el derecho a la igualdad es transversal a todos con diferentes matices. No debemos olvidar que los blogs son sitios institucionales que guardan un lugar accesorio con respecto a estos medios de comunicación. Y si consideramos que en cuatro años hubo un número 
muy escueto de editoriales sobre las personas LGBTIQ en los diarios y en paralelo hay dos blogs que abordan temas de diversidad sexo-genérica, podemos pensar que el tratamiento residual de estos asuntos en los diarios se condice con la apertura políticamente correcta de dos blogs LGBTIQ. Y si bien en ellos hay diversas opiniones con representaciones que refuerzan un orden binario cisheteronormativo así como otras que resisten, los moderadores no están contribuyendo a que sus blogs sean espacios libres de discriminación. En todo caso, sus blogs son dos plataformas virtuales más de Clarín y La Nación para difundir (no sin resistencias) discursos tendientes a preservar el status quo cisheterosexual con los privilegios de antaño; y la incitación a "que haya debate" no es más que un mecanismo para disuadir la moderación de los comentarios adversos y la participación de las personas que podrían hallar en Tx o en BP un espacio de socialización o consulta entre pares en vez de un derrotero de insultos y ataques.

Para finalizar, creemos que los discursos normalizadores que circulan en los espacios digitales obturan el ejercicio de la ciudadanía plena de las personas LGBTIQ y son discursos de hétero-resistencia en un período teñido por procesos de cambio en pos del reconocimiento formal de los sujetos queer. Los textos discriminatorios analizados ejemplifican el potencial conservador de la violencia, lo materializan en palabras y lo envuelven con el manto de la corrección política por la igualdad y la protección de todas las personas, o bien la violencia queda al descubierto y manifiesta su malestar, su asco y su desprecio por todos los seres abyectos en un clima de descontento político y social. Por ello, sería oportuno que futuras investigaciones rastreen continuidades y rupturas entre los momentos históricos anteriores y posteriores a las elecciones presidenciales de 2015 con el propósito de conocer si persisten las prácticas que vulneran los derechos de los sujetos queer en los cuatro sitios tras el cambio de gestión. Y, de aprobarse algún proyecto de ley contra la discriminación, sería propicio indagar si se modifican o no las prácticas discriminatorias homofóbicas en BP y Tx o en sitios similares para que de esa manera se pueda reflexionar acerca de los nuevos horizontes discursivos y las tramas de significaciones presentes en las disputas hegemónicas y contra-hegemónicas en ese entonces con el fin de contribuir a la inclusión, aceptación y reconocimiento integral de las personas LGBTIQ. 


\section{BIBLIOGRAFÍA}

Libros y artículos en revistas académicas:

- 100\% Diversidad y Derechos (2016) "Resumen ejecutivo", Encuesta Nacional de Clima Escolar 2016 para jóvenes LGBTIQ, Buenos Aires. Disponible en https://100porciento.files.wordpress.com/2016/12/resumen-ejecutivo-encuesta-nacionalde-ambiente-escolar.pdf [Consultado el 8 de mayo de 2017]

- ALABARCES, P. (2002) "Estudios culturales", en ALTAMIRANO, C. (comp.) Términos críticos de sociología de la cultura, Buenos Aires: Paidós.

- ANDER-EGG, E. (1990) "Fases e instrumentación del proceso de la InvestigaciónAcción-Participativa", Repensando la Investigación-Acción-Participativa, Buenos Aires: Lumen Hvmanitas.

- AUYERO, J. (2007) La zona gris: violencia colectiva y política partidaria en la Argentina contemporánea, Buenos Aires: Siglo XXI, pp. 101-127.

- BAGLEY, B. (2012) El tráfico de drogas y el crimen organizado en América, Washington: Woodrow Wilson Center Update on the Americas.

- BARON, N. (2011) “Assessing the Internet's impact on language”, en CONSALVO, M. y ESS, C. (eds.) The Handbook of Internet Studies, Oxford: Wiley-Blackwell, pp. 117-136.

- BARTON, D. y LEE, C. (2013) Language online: investigating digital texts and practices, Oxford: Routledge, pp. 1-22.

- BASSET, U., RODRÍGUEZ GALÁN, A. y VÍTOLO, A. (2016) "The enforcement and effectiveness of Anti-Discrimination Law: Argentina", Actas del Congreso Temático de Derecho Comparado (IACL), Montevideo: AIDC, pp.1-12. Disponible en http://tc.iuscomparatum.info/tc/wp-content/uploads/2016/09/Panelists-report-GRMercat-Bruns-Oppenheimer-1.pdf [Consultado el 10 de marzo de 2017]

- BAZÁN, O. (2010) Historia de la homosexualidad en Argentina. De la conquista de América al siglo XXI, Buenos Aires: Marea. 
- BECKER, H. (2009) Outsiders. Hacia una sociología de la desviación, Buenos Aires: Siglo XXI.

- BELlUCCI, M. (2010) Orgullo. Carlos Jáuregui, una biografía política, Buenos Aires: Emecé.

- BENHABIB, S. (2002) "Introducción. Sobre el uso y el abuso de la cultura", Las reivindicaciones de la cultura: igualdad y diversidad en la era global, Buenos Aires: Katz.

- BENJAMIN, W. (2001) "Para una crítica de la violencia", Para una crítica de la violencia y otros ensayos, Buenos Aires: Taurus, pp. 23-45.

- BERKINS, L. (2009) "Un itinerario político del travestismo", en MAFFÍA, D. (comp.) Sexualidades migrantes, Buenos Aires: Librería de Mujeres Editoras, pp. 143155.

- BERTONI, E. y SADINSKY, S. (2015) "The use of the DMCA to stiffle free expression", en Revista de Derecho, Comunicación y Nuevas Tecnologías, Facultad de Derecho, Universidad de Los Andes.

- BESSONE, C. (2010) "Algunos problemas del campo comunicacional: revisión de sus posibilidades como ciencia”, Revista Questión, Vol. 1, № 28, La Plata: UNLP.

- BHABHA, H. (1994) "Diseminación. El tiempo, el relato y los márgenes de la nación moderna", El lugar de la cultura, Buenos Aires: Manantial, pp. 175-209.

- BIMBI, B. (2010) Matrimonio igualitario. Intrigas, tensiones y secretos en el camino hacia la ley, Buenos Aires: Planeta.

- BORRILlO, D. (2010) Homofobia, história e crítica de um preconceito, Belo Horizonte: Auténtica Editora.

- BOURDIEU, P. (2000) La dominación masculina, Barcelona: Editorial Anagrama.

- BOY, M. (2008) "Significaciones y usos del espacio virtual en hombres gays de Buenos Aires", en PECHENY, M., FIGARI, C. y JONES, D. (comps.) Todo sexo es político. Estudios sobre sexualidades en Argentina, Buenos Aires: Libros del Zorzal, pp. 73-94.

- BRAIDOTTI, R. (1994) Sujetos nómades, Buenos Aires: Paidós.

- BRAMAN, S. (2011) "Internet policy”, en CONSALVO, M. y ESS, C. (eds.) The Handbook of Internet Studies, Oxford: Wiley-Blackwell, pp. 137-167. 
- BROMSETH, J. y SUNDÉN, J. (2011) “Queering Internet studies: intersections of gender and sexuality", en CONSALVO, M. y ESS, C. (eds.) The Handbook of Internet Studies, Oxford: Wiley-Blackwell, pp. 271-299.

- BROWN, S. (2002) “Con discriminación y represión no hay democracia', the lesbian and gay movement in Argentina", en Latin American perspectives, 29 (2), pp. 119-138.

- BROWNE, K. y NASH, C. (eds.) (2016) "Queer methods and methodologies: an introduction", Queer methods and methodologies: intersecting queer theories and Social Science research, Oxford: Routledge, pp. 1-23.

- BUSANICHE, B. (2015) "Proyecto de Ley Antidiscriminación: una supuesta solución que amplia los problemas", Fundación Vía Libre. Disponible en http://www.vialibre.org.ar/wp-content/uploads/2015/07/discriminacion.pdf [Consultado el 20 de marzo de 2016]

- BUTLER, J. (1990) El género en disputa, Barcelona: Paidós.

- BUTLER, J. (1993) Cuerpos que importan, Buenos Aires: Paidós, pp. 53-94.

- BUTLER, J. (1994) "Against proper objects", differences: A Journal of Feminist Cultural Studies, Vol. 6, N²/3, pp. 1-27.

- BUTLER, J. (1997) Lenguaje, poder e identidad, Madrid: Editorial Síntesis.

- BUTLER, J. (2004) Deshacer el género, Barcelona: Paidós.

- CABRERA, D. (2006) "Lo tecnocomunicacional", Lo tecnológico y lo imaginario, Buenos Aires: Biblos.

- CAMPAGNOLI, M. (2008) "La mujer barbuda: una mirada epistemosexual”, Actas de las VII Jornadas de Investigación en Filosofía, 10, 11 y 12 de noviembre de 2008, La Plata: FAHCE-UNLP.

- CAMPAGNOLI, M. (2013) "El feminismo en cueros", Actas del III Congreso CINIG, La Plata: FAHCE-UNLP.

- CARAVACA, E. (2014) "De qué hablamos cuando hablamos de linchamientos: una sociología de la actualidad", Revista Questión, Vol. 1, No 42, La Plata: UNLP.

- CARRIÓN, F. (2015) "La red global del narcotráfico", Perspectivas de una Corte Penal Regional en el marco de la UNASUR, Quito: FGE-ILDIS.

- CARRIÓN, F. (2016) "Mercados ilegales: nueva arquitectura institucional del narcotráfico y su expresión territorial en Latinoamérica”, Sistema Fronteriza Global, Guatemala: FLACSO. 
- CARRIZO, A. (2015) "La violencia verbal en el discurso público: los comentarios en los diarios digitales", Actas del X Congreso Internacional de ALED, Puebla: Universidad Autónoma de Puebla, 28 al 31 de octubre de 2013.

- CASTELlS, M. (2001) “Internet y la Sociedad Red", Lección inaugural del programa de doctorado sobre la sociedad de la información y el conocimiento (UOC). Recuperado de http://tecnologiaedu.us.es/cuestionario/bibliovir/106.pdf [Consultado el 15 de abril de 2015].

- CASTORIADIS, C. (1993) "Transformación social y creación cultural", Comunicación, № 81, Caracas: Centro Gumilla, pp. 14-22.

- CELE (2013) Informe: "Internet en Argentina: ¿cómo estamos hoy? Mapeo de la situación en materia de acceso, regulación y derechos humanos", Universidad de Palermo. Disponible en http://www.palermo.edu/cele/pdf/investigaciones/MappingARG-CELE.pdf [Consultado el 20 de marzo de 2016]

- CELS (2015) Carta del Centro de Estudios Legales y Sociales a la HCDN sobre el proyecto de Ley Nacional contra la Discriminación (Expte. 9064-D-15). Disponible en http://www.cels.org.ar/common/documentos/Proyecto $\% 20 \mathrm{de} \% 201$ ey $\% 20$ antidiscrimina ci\%C3\%B3n.pdf [Consultado el 6 de septiembre de 2015]

- CIDH (2015a) "Annual Report of the Office of the Special Rapporteur for Freedom of Expression", Annual report of the Inter-American Commission on Human Rights, 2015, Vol. 2. 2 Disponible en http://www.oas.org/en/iachr/expression/docs/reports/annual/AnnualReport2015RELE.p df [Consultado el 25 de mayo de 2016].

- CIDH (2015b) Violencia contra personas gays, lesbianas, bisexuales, trans e intersex en América, OEA Documentos oficiales. Disponible en http://www.oas.org/es/ cidh/informes/pdfs/ViolenciaPersonasLGBTI.pdf [Consultado el 1 de febrero de 2016]

- CIDH (2017) “Informe anual de la Relatoría Especial para la Libertad de Expresión”, Informe anual de la Comisión Interamericana de Derechos Humanos, 2016, Vol. 2, OEA Documentos oficiales.

- CITRON, D. K. (2009) "Law's expressive value in combating cyber gender harassment", en Legal Studies Research Paper, $\mathrm{N}^{\circ}$ 11, Escuela de Derecho de la Universidad de Maryland, pp. 373-416.

- COLÓN ZAYAS, E. R. (2012) “Amanecer en la Era del Acuario. Walter Mercado, estrella del performance camp y queer", en FORASTELLI, F. y OLIVERA, G. 
(coords.) Estudios queer. Semióticas y políticas de la sexualidad, Buenos Aires: La Crujía, pp. 67-78.

- CONNELL, R. (1997) “La justicia curricular”, Escuelas y justicia social, Madrid: Morata.

- CONSTANTINO, G. (2006) "Discurso didáctico electrónico: los modos de interacción discursiva en el ala virtual en contraste con el aula presencial", Linguagem em (Dis)curso, Vol. 6, № 2, pp. 241-267.

- COTTER, C. (2003) "Discourse and media", en SCHIFFRIN, D., TANNEN, D. y HAMILTON, H. (eds.) The Handbook of Discourse Analysis, Cornwall: Blackwell.

- DE KERCKHOVE, D. (1999) "La web", Inteligencias en conexión, Barcelona: Gedisa.

- DE LAURETIS, T. (1987) Technologies of gender. Essays on Theory, Film and Fiction. Bloomington e Indianápolis: Indiana University Press. Caps. 1 y 2.

- DELEUZE, G. y GUATTARI, F. (1980) Mil Mesetas. Capitalismo y esquizofrenia, Valencia: Pre-textos.

- DELFINO, S. (1998) "Desigualdad y diferencia: retóricas de la identidad en la crítica de la cultura", en Revista Doxa, $\mathrm{N}^{\circ} 18$, Buenos Aires.

- DELFINO, S. (2009) "Investigación y activismo en el vínculo entre teorías de género, identidad de géneros y luchas políticas", Revista Tram[p]as de la Comunicación y la Cultura, $\mathrm{N}^{\circ} 66$, pp. 36-54.

- DELFINO, S. y RAPISARDI, F. (2010) "Cuirizando la cultura argentina desde La Queerencia. Centro criollo de políticas de la diferencia", Ramona. Revista de artes visuales, $\mathrm{N}^{\circ} 99$, Buenos Aires: Fundación Start.

- DENNIS, J. P. (2015) “What is homosexuality doing in deviance?”, en GOODE, E. (ed.). The handbook of deviance, Oxford: Wiley Blackwell, pp. 172-188.

- DORLIN, E. (2009) Sexo, género y sexualidades. Introducción a la teoría feminista, Buenos Aires: Nueva Visión, pp. 31-89.

- ELÍADES, A. (2003) "Historia legal de la radio y la televisión en la Argentina", en Oficios Terrestres, No 13, FPyCS-UNLP, pp. 32-56.

- ENCARNACIÓN, O. (2013) "International influence, domestic activism, and gay rights in Argentina", en Political Science Quarterly, 128 (4), Academy of Political Science, pp. 687-716. 
- ESS, C. y CONSALVO, M. (2011) "Introduction: what is 'Internet Studies'?" The Handbook of Internet Studies, Oxford: Wiley-Blackwell, pp. 1-8.

- FALGBT (2017) "Primer informe del Observatorio Nacional de Crímenes de Odio hacia la Comunidad LGBT en Argentina", Observatorio Nacional de Crímenes de odio LGBT. Disponible en: http://www.defensoria.org.ar/wpcontent/uploads/2017/03/Observatorio-Nacional-de-Cr\%C3\%ADmenes-de-OdioLGBT.pdf [Consultado el 10 de marzo de 2017]

- FARJI NEER, A. (2014) "Las tecnologías del cuerpo en el debate público. Análisis del debate parlamentario de la Ley de Identidad de Género en Argentina", en Sexualidad, Salud y Sociedad, N 16, pp. 50-72.

- FEMENÍAS, M. L. (2007) "La exaltación de la diferencia”, El género del multiculturalismo, Bernal: Universidad Nacional de Quilmes, pp. 69-118.

- FERGUSON, J. (2013) "Queering methodologies: challenging scientific constraint in the appreciation of queer and trans subjects", The Qualitative Report, Vol. 18, pp. 1-13. - FERNÁNDEZ, A. M. (2009) "Violencias, desigualaciones y géneros”, Las lógicas sexuales: amor, politica y violencias, Buenos Aires: Nueva Visión, pp. 33-50.

- FIGARI, C. (2009) "Las emociones de lo abyecto: repugnancia e indignación”, en FIGARI, C. y ESCRIBANO, A. (comps.) Cuerpo(s), subjetividad(es) y conflicto(s). Hacia una sociología de los cuerpos y las emociones desde Latinoamérica, Buenos Aires: Cicccus-CLACSO, pp. 131-139.

- FONE, B. (2008) Homofobia: una historia, México: Océano.

- FORASTELLI, F. (2007) "Regulaciones culturales y violencia. Recientes debates en el movimiento de mujeres y queer en América Latina", Feminismo/s, N 9, junio 2007, pp. 51-66.

- FORASTElli, F. y OLIVERA, G. (coords.) (2012) Estudios queer. Semióticas y políticas de la sexualidad, Buenos Aires: La Crujía.

- FOUCAULT, M. (1970) El orden del discurso, Buenos Aires: Tusquets Editores.

- FOUCAULT, M. (1976) La historia de la sexualidad, la voluntad del saber, Buenos Aires: Siglo XXI.

- FOUCAULT, M. (1984a) La historia de la sexualidad, el uso de los placeres, Buenos Aires: Siglo XXI.

- FOUCAULT, M. (1984b) La historia de la sexualidad, la inquietud de sí, Buenos Aires: Siglo XXI. 
- GAGLiARDONE, I., GAL, D., ALVES, T. y MARTINEZ, G. (2015) Countering online hate speech, París: UNESCO Series on Internet freedom.

- GAILlE, B. (20 de noviembre de 2013) "How many blogs are on the Internet", WPVirtuoso. Disponible en http://www.wpvirtuoso.com/how-many-blogs-are-on-theinternet [Consultado el 1 de febrero de 2016]

- GAMSON, J. (2002) “DDeben autodestruirse los movimientos identitarios? Un extraño dilema”, en MÉRIDA JIMÉNEZ, R. (ed.) Sexualidades transgresoras. Una antología de estudios queer, Barcelona: Icaría, pp. 141-172.

- GARCÍA CANCLINI, N. (1997) "El malestar en los estudios culturales”, en Fractal $\mathrm{N}^{\circ}$ 6, vol. 2, pp. 45-60.

- GARCÍA CANCLINI, N. (2001) "Las culturas híbridas en tiempos globalizados", Culturas híbridas. Estrategias para entrar y salir de la modernidad, Barcelona: Paidós.

- GARRIGA ZUCAL, J. y NOEL, G. (2010) "Notas para una definición antropológica de la violencia: un debate en curso", Revista PUBLICAR en Antropología y Ciencias Sociales, $\mathrm{N}^{\circ}$ 9, pp, 97-121.

- GEHL, R. (2016) "Power/freedom on the dark web: a digital ethnography of the Dark Web Social Network", New media \& society, Vol. 18, № 7, pp. 1219-1235.

- GIL, A. (2014) "La violencia de género en los diarios Clarín y La Nación. De sentidos hegemónicos y usos políticos”, Revista Comunicación y Medios, $\mathrm{N}^{\circ} 30$, Universidad de Chile, pp. 157-175.

- GLSEN (2013) Out Online: the experiences of lesbian, gay, bisexual and transgender youth on the Internet, Nueva York: GLSEN, 42 pp.

- GOBATO, F. (2014) La escritura secundaria. Oralidad, grafía y digitalización en la interacción contemporánea, Bernal: UNQ.

- GONZÁlEZ, L., LADEUIX, J. y FERREYRA, G. (2011) “Acciones colectivas de violencia punitiva en la Argentina reciente”, Bajo el Volcán, Vol. 10, N 16, México, pp. 165-193.

- GOUVEIA, C. (2005) "Assumptions about gender, power and opportunity: gays and lesbians as discursive subjects in a Portuguese newspaper", en LAZAR, M. (ed.) Feminist critical discourse analysis: gender, power and ideology, Londres: Palgrave McMillan, pp. 229-250.

- GREEN, M., BOBROWICZ, A. y ANG, C. (2015) "The lesbian, gay, bisexual and transgender community online: discussions of bullying and self-disclosure in YouTube 
videos", en Behaviour \& Information Technology, № 34 (7), Taylor \& Francis, pp. 704712.

- GRIMSON, A. (2011) "Dialéctica del culturalismo", en Los límites de la cultura. Crítica de las teorías de la identidad, Buenos Aires: Siglo XXI.

- GROSSBERG, L. (1996) "Identidad y estudios culturales: ¿no hay nada más que eso?", en HALL, S. y DU GAY, P. (eds.) Cuestiones de identidad cultural, Madrid: Amorrotu, pp. 148-180.

- GROSSBERG, L. (2009) "El corazón de los estudios culturales: contextualidad, construccionismo y complejidad", en Tabula Rasa, N 10, Bogotá, pp. 13-48.

- GROSSBERG, L. (2012) Estudios culturales en tiempo futuro. Cómo es el trabajo intelectual que requiere el mundo de hoy, Buenos Aires: Siglo XXI.

- GUTIÉRREZ, M. A. (2016) “'La revolución de la alegría’: rupturas y continuidades en las políticas sobre género y sexualidades", Ciencias Sociales, Revista de la Facultad de Ciencias Sociales, $\mathrm{N}^{\circ}$ 92, UBA, pp. 35-39.

- HALL, S. (1992) “Cultural Studies and its Theoretical Legacies”, en GROSSBERG, L., NELSON, C. y TREICHLER, P. (eds.) Cultural Studies, Londres: Routledge.

- HALL, S. (1996) “Introducción: ¿Quién necesita ‘identidad’?”, en HALL, S. y DU GAY, P. (eds.) Cuestiones de identidad cultural, Madrid: Amorrotu, pp. 13-39.

- HALL, S. (2010) Sin garantías, Popayán: Envión editores.

- HALPERIN, D. (2000) "La política queer de Michel Foucault", San Foucault para una hagiografía gay), Córdoba: Cuenco del Plata-Edelp.

- HALPERIN, D. (2003) "The normalization of queer theory", Journal of Homosexuality, Vol. 45, N²-4, pp. 339-343.

- HAN, B. C. (2014) En el enjambre, Barcelona: Herder.

- HARAWAY, D. (1995) Ciencia, cyborgs y mujeres, Madrid: Ediciones Cátedra, pp. 213-311.

- HERRING, S. C. (2002) "Cyber violence: Recognizing and resisting abuse in online environments", Asian Women, $\mathrm{N}^{\circ} 14$. Disponible en http://ella.slis.indiana.edu/ herring/ violence.html [Consultado el 15 de enero de 2016].

- HERRING, S. C. (2003) "Gender and power in on-line communication", en HOLMES, J. y MEYERHOFF, M. (eds.) The handbook of language and gender, Oxford: Blackwell Publishing. 
- HERRING, S., JOB-SLUDER, K., SCHECKLER, R. y BARAB, B. (2002)

"Searching for safety online: managing 'trolling' in a feminist forum", The Information Society, $\mathrm{N}^{\circ} 18$, pp. 371-384.

- HESSE-BIBER, S., RODRIGUEZ, D. y FROST, N. (2015) “A qualitatively driven approach to multimethod and mixed method research", en HESSE-BIBER, S. y JOHNSON, R. (eds.) The Oxford Handbook of Multimethod and Research Inquiry, Londres: Oxford University Press, pp. 3-20.

- HINE, C. (2000) Virtual ethnography, Londres: SAGE Publications.

- INADI (2014) Mapa nacional de la discriminación, segunda edición, Ciudad Autónoma de Buenos Aires: INADI.

- ISLA, A. y MIGUEZ, D. (2003) Heridas urbanas, violencia delictiva y transformaciones sociales en los noventa, Buenos Aires: Editorial de las Ciencias.

- ISLAS, O. (2013) “Comprendiendo el tránsito de la blogósfera a la twitósfera”, en ISLAS, O. y RICAURTE, P. (comps.) Investigar las redes sociales. Comunicación total en la sociedad de la ubicuidad, México: Razón y Palabra, pp. 67-77.

- JENSEN, K. (2011) "New media, old methods - Internet methodologies and the online/offline divide", en CONSALVO, M. y ESS, C. (eds.) The Handbook of Internet Studies, Oxford: Wiley-Blackwell, pp. 43-58.

- JENSEN, K. y HELLES, R. (2010) "The Internet as a cultural forum: implications for research", New media \& society, Vol. 13, $\mathrm{N}^{\circ}$ 4, pp. 517-533.

- JEWITT, C. (2016) "Multimodal analysis", en GEORGAKOPOULOU, A. y SPILLOTI, T. (eds.) The Routledge Handbook of Language and Digital Communication, Oxford: Routledge, pp. 69-84.

- JEWITT, C. (ed.) (2014) The Routledge Handbook of Multimodal Analysis, Oxford: Routledge, pp. 15-43.

- JONES, D. (2008) "Estigmatización y discriminación a adolescentes varones homosexuales", en PECHENY, M., FIGARI, C. y JONES, D. (comps.) Todo sexo es político. Estudios sobre sexualidades en Argentina, Buenos Aires: Libros del Zorzal, pp. 47-71.

- KAPLAN, N. (2004) "Nuevos desarrollos en el estudio de la evaluación en el lenguaje: la teoría de la valoración”, Boletín de lingüística, Vol. №22, julio/diciembre, Caracas: Universidad Central de Venezuela. 
- KATZ, J. (1988) Seductions of crime. A chilling exploration of the criminal mind, from juvenile delinquency to cold-blooded murder, Nueva York: Basic Books, pp. 3-11, 114-163.

- LACOMBE, A. (2012) “Além das fronteiras da pele: masculinidades de mulheres em um bar do centro do Rio de Janeiro", en FORASTELLI, F. y OLIVERA, G. (coords.) Estudios queer. Semióticas y políticas de la sexualidad, Buenos Aires: La Crujía, pp. 144-152.

- LAMAS, M. (1996) “Usos, dificultades y posibilidades de la categoría género”, El género. La construcción cultural de la diferencia sexual, México: Programa Universitario de Estudios de Género de la Universidad Nacional Autónoma de México.

- LATHER, P. (1986) "Issues of validity in openly ideological research: between a rock and a soft place", Revista Interchange, Vol. 17, N 4, Ontario Institute for Studies in Education, pp. 63-84.

- MAFFÍA, D. (2014) "Normalidad y alteración sexual en los 50: el primer departamento sexológico", en BARRANCOS, D., GUY, D. y VALOBRA, A. (eds.) Moralidades y comportamientos sexuales, Buenos Aires: Biblos, pp. 217-231.

- MAFFÍA, D. y CABRAL, M. (2009) “Los sexos ¿son o se hacen?”, en MAFFÍA, D. (comp.) Sexualidades migrantes, Buenos Aires: Librería de Mujeres Editoras, pp. 95107.

- MANOVICH, L. (2006) “QQué son los nuevos medios?”, El lenguaje de los nuevos medios de comunicación, Buenos Aires: Paidós.

- MANSILlA, G. (2014) Yo nena, yo princesa: Luana, la niña que eligió su propio nombre, Los Polvorines: Universidad de General Sarmiento.

- MARIN, L. (2009) “Poder, representación, imagen”, en Revista Prismas No2, vol 13, Bernal, pp. 135-153. Disponible en: http://www.unq.edu.ar/advf/documentos/ 51f6a2f59bbe8.pdf [Consultado el 20 de diciembre de 2015]

- MARISTANY, J. (2008) “¿Una teoría queer latinoamericana? Postestructuralismo y políticas de la identidad en Lemebel", Lectures $d u$ genre, $\mathrm{N}^{\circ} 4$. Disponible en https://espanol.free-ebooks.net/ebook/Una-teoria-queer-

latinoamericana/pdf?dl\&preview [Consultado el 10 de enero de 2016]

- MARTÍN BARBERO, J. (2010) "Notas para hacer memoria de la investigación cultural en Latinoamérica", en RICHARD, N. (comp.) En torno a los estudios culturales. Localidades, trayectorias y disputas, Santiago de Chile: ARCIS-CLACSO. 
- MARTIN, J. R (2004) "Mourning: how we get aligned", Discourse \& society, Vol. 15, Londres: SAGE Publications. Disponible en http://www.grammatics.com/ appraisal/Mourning-HowWeAreAligned-Martin-JR.pdf [Consultado el 17 de julio de 2012]

- MARTÍNEZ, M. (2016) "La violencia y la palabra: sobre el acto de decir en las redes", Ciencias Sociales, Revista de la Facultad de Ciencias Sociales, N 92, UBA, pp. $40-45$.

- MARWICK, A. y LEWIS, R. (2017) Media manipulation and disinformation online, Nueva York: Data \& Society Research Institute. Disponible en https://datasociety.net/pubs/oh/DataAndSociety_MediaManipulationAndDisinformation Online.pdf [Consultado el 20 de junio de 2017]

- MATTIO, E. (2012) “¿De qué hablamos cuando hablamos de género? Una introducción conceptual", en MORÁN FAÚNDES, J., SGRÓ RUATA, M. C. y VAGGIONE, M. (eds.). Reflexiones en torno a los derechos sexuales y reproductivos, Córdoba: Ciencia, Derecho y Sociedad Editorial, pp. 85-102.

- McKEE IRWIN, R. (2009) “Teoría queer”, en SZURMUK, M. y McKEE IRWIN, R. (comps.) Diccionario de los estudios culturales latinoamericanos, México: Siglo XXIInstituto Mora.

- MECCIA, E. (2008) "La carrera moral de Tommy. Un ensayo en torno a la transformación de la homosexualidad en categoría social y sus efectos en la subjetividad", en PECHENY, M., FIGARI, C. y JONES, D. (comps.) Todo sexo es político. Estudios sobre sexualidades en Argentina, Buenos Aires: Libros del Zorzal, pp. 21-45.

- MELO, A. (2008) Otras historias de amor. Gays, lesbianas y travestis en el cine argentino, Buenos Aires: Ediciones Lea.

- MÉRIDA JIMÉNEZ, R. (2009) "Prólogo: emergencias, reflexiones y combates", Manifiestos gays, lesbianos y queer: testimonios de una lucha (1969-1994), Barcelona: Icaría.

- MONEDERO, J. C. (2016) Lenguaje, ideología y poder. La palabra como arma de persuasión ideológica: cultura y legislación, Buenos Aires: Ediciones Castilla.

- MONTEAGUDO, M. L. (comp.) (2011) Quilmes contra la discriminación, la xenofobia y el racismo, Quilmes: Municipalidad de Quilmes. 
- MOOR, P. (2007) Conforming to the flaming norm in the online commenting situation. Tesis de grado, Universidad de Twente. Disponible en http://scholar.petermoor.nl/flaming.pdf [Consultado el 20 de febrero de 2017]

- MOREIRA, M. (2010) "Escalas y expectativas sociales de la justicia en la Argentina: la justicia colectiva y el linchamiento simbólico", Antropología y Derecho, $\mathrm{N}^{\circ} 8$, Posadas.

- MORENO, A. (2008) "La invisibilidad como injusticia. Estrategias del movimiento de la diversidad sexual", en PECHENY, M., FIGARI, C. y JONES, D. (comps.) Todo sexo es político. Estudios sobre sexualidades en Argentina, Buenos Aires: Libros del Zorzal, pp. 217-243.

- MYERS, G. (2010) "Stance-taking and public discussion in blogs", en Critical Discourse Studies, Vol. 7, № 4, pp. 263-275.

- NASH, V. (2013) "Analyzing freedom of expression online: theoretical, empirical, and normative contributions", en DUTTON, W. (ed.) The Oxford Handbook of Internet Studies, Oxford: Oxford University Press, pp. 441-463.

- NATANSOHN, G. (2013) “QQué tienen que ver las tecnologías digitales con el género?", Internet en código femenino, Buenos Aires: La Crujía, pp. 15-36.

- NOBLIA, M. V. (2004) "Una aproximación teórica y práctica a la definición del chat como género discursivo", en SANTOS, S. y PANESI, J. (eds.) Actas del Congreso Internacional: Debates actuales. Las teorías críticas de la literatura y la lingüística, Buenos Aires: UBA.

- NOBLIA, V. (2009) "Modalidad, evaluación e identidad en el chat", en Discurso y sociedad, Vol. 3, $\mathrm{N}^{\circ}$ 4. Disponible en http://www.dissoc.org/ediciones/v03n04/DS3(4) Noblia.pdf [Consultado el 10 de noviembre de 2016].

- O’SULLIVAN, P. y FLANAGIN, A. (2003) 'Reconceptualizing 'flaming' and other problematic messages", New media \& society, Vol. 5, N 1, SAGE Publications, pp. 6994.

- OLESEN, V. (2011) “Feminist qualitative research in the millennium's first decade: developments, challenges, prospects", en DENZIN, N. y LINCOLN, Y. (eds.) The $4^{\text {th }}$ SAGE Handbook of Qualitative Research, California: SAGE, pp. 129-146.

- OLIVERA, G. (2012) "Entre lo innombrable y lo enunciable: visibilidades y espacialidades LGBT en el cine argentino (1960-1991)", en FORASTELLI, F. y 
OLIVERA, G. (coords.) Estudios queer. Semióticas y politicas de la sexualidad, Buenos Aires: La Crujía, pp. 99-111.

- OROZCO GÓMEZ, G. (1996) "La perspectiva cualitativa", La investigación en comunicación desde la perspectiva cualitativa, La Plata: EDULP.

- OSZLAK, O. (2011) "Falsos dilemas: micro-macro, teoría-caso, cuantitativocualitativo", en WAINERMAN, C. y SAUTÚ, R. (comps.) La trastienda de la investigación, Buenos Aires: Editorial Manantial.

- PELAZAS, M. (2016) “Cuando Violencia Rivas se junta con Micky Vainilla: violencia y discriminación en las pantallas de TV", Ciencias Sociales, Revista de la Facultad de Ciencias Sociales, N 92, UBA, pp. 95-99.

- PÉREZ RIEDEL, M. (2014) Género y diversidad sexual en el blog Boquitas pintadas. Bernal: Unidad de Publicaciones para la Comunicación Social de la Ciencia, Departamento de Ciencias Sociales de la Universidad Nacional de Quilmes.

- PÉREZ RIEDEL, M. (2015) "Hacia un análisis de páginas argentinas gay-friendly", ponencia presentada en el VIII Seminario Regional (Cono Sur) de ALAIC. 27 y 28 de agosto de 2015, ECI-UNC.

- PÉREZ, V. y REBÓN, J. (2011) “Tiempo de estallidos. La disconformidad de los pasajeros de trenes urbanos", Documento de trabajo, $\mathrm{N}^{\circ}$ 57, Buenos Aires.

- PERLONGHER, N. (2008) "Historia del Frente de Liberación Homosexual Argentina", Prosa plebeya: ensayos, 1980-1992, Buenos Aires: Colihue, pp. 77-84.

- PINEDA, M. (2001) “QQué investigar hoy sobre comunicación en América Latina?”, Revista Diálogos de la Comunicación, º 62, Lima: FELAFACS, pp. 77-83.

- PLUMMER, K. (2011) “Critical humanism and queer theory", en DENZIN, N. y LINCOLN, Y. (eds.) The $4^{\text {th }}$ SAGE Handbook of Qualitative Research, California: SAGE, pp. 195-211.

- POCAHY, F. y CARPENDO, M. (2012) "No rastro do prazer: problematizando prácticas sexuais, sociabilidades e violências", en FORASTELLI, F. y OLIVERA, G. (coords.) Estudios queer. Semióticas y políticas de la sexualidad, Buenos Aires: La Crujía, pp. 121-132.

- PRECIADO, P. B. (2002) Manifiesto contra-sexual, Madrid: Opera Prima, pp. 3798, 139-155.

- PRECIADO, P. B. (2008) "Micropolíticas de género en la era farmacopornográfica. Experimentación, intoxicación voluntaria, mutación”, Testo yonqui, Madrid: Espasa. 
- PRECIADO, P. B. (2009) "Terror anal”, en HOCQUENGHEM, G. ([1972]), El deseo homosexual, Barcelona: Melusina, pp. 135-174.

- RAMACCIOTTI, K. y VALOBRA, A. (2014) “'Peor que putas”: tríbadas, safistas y homosexuales en el discurso moral hegemónico del campo médico, 1936-1954”, en BARRANCOS, D., GUY, D. y VALOBRA, A. (eds.) Moralidades y comportamientos sexuales, Buenos Aires: Biblos, pp. 195-216.

- RAPISARDI, F. (2008) "Escritura y lucha política en la cultura argentina: identidades y hegemonía en el movimiento de diversidades sexuales entre 1970 y 2000”, en Revista Iberoamericana, 74 (225), pp. 973-993.

- RAPISARDI, F. y BELLUCCI, M. (2001) "Identidad: diversidad y desigualdad en las luchas políticas del presente", en BORÓN, A. y DE VITA, A. (comps.) Teoría y filosofía política. La recuperación de los clásicos en el debate latinoamericano, Buenos Aires: CLACSO, pp. 193-207.

- RAWLS, J. (1993) Liberalismo político, México: Fondo de Cultura Económica, pp. 29-203.

- RAWLS. J. (1971) Teoría de la Justicia, México: Fondo de Cultura Económica, pp. 17-184.

- RECALDE, A. (2008) “Análisis de la Ley del Servicio de Radiodifusión 14.241 del año 1953", en Revista Questión, Vol. 1, № 18, FPyCS-UNLP. Disponible en http://perio.unlp.edu.ar/ojs/index.php/question/article/view/602/513 [Consultado el 13 de noviembre de 2016]

- RESTREPO, E. (2007) "Identidades: planteamientos teóricos y sugerencias metodológicas para su estudio", en Jangwa Pana, № 5, pp. 24-35.

- RESTREPO, E. (2011) "Estudios culturales y educación: posibilidades, urgencias y limitaciones", en Revista de investigaciones $\mathrm{N}^{\circ} 10$, Bogotá: UNAD.

- RESTREPO, E. (2012) Antropología y estudios culturales. Disputas y confluencias desde la periferia, Buenos Aires: Siglo XXI.

- RICE, R. y FULLER, R. (2013) "Theoretical perspectives in the study of communication and the Internet", en DUTTON, W. (ed.) The Oxford Handbook of Internet Studies, Oxford: Oxford University Press, pp. 353-377.

- RICHARD, N. (2009) "La crítica feminista como modelo de crítica cultural”, en Debate feminista, año 20, vol. 40. 
- RICHARD, N. (2010) "Respuestas a un cuestionario: posiciones y situaciones", en En torno a los estudios culturales. Localidades, trayectorias y disputas, Santiago de Chile: ARCIS-CLACSO.

- RICHES, D. (1986) “The phenomenon of violence", The Anthropology of Violence, Oxford: Bassil-Blackwell.

- RODRÍGUEZ, M. G. (2011) "Palimpsestos: Mapas, territorios y representaciones mediáticas", en Reflexiones Marginales, $\mathrm{N}^{\mathrm{o}}$ 10, México: UNAM. Disponible en http://v2.reflexionesmarginales.com/index.php/num10-dossier-blog/213-palimpsestosmapas-territorios-y-representaciones-mediaticas [Consultado el 10 de enero de 2016] - ROSA, P. (2009) “La ciencia que se está haciendo. Reflexiones metodológicas de la mano de Pierre Bourdieu", KAIROS. Revista de Temas Sociales, № 24, San Luis: Universidad Nacional de San Luis.

- SABANES PLOU, D. (2013) "Nuevos escenarios, viejas prácticas de dominación: la violencia contra las mujeres en la era digital", en NATANSOHN, G. (coord.) Internet en código femenino, Buenos Aires: La Crujía, pp. 107-121.

- SAlESSI, J. (1995) Médicos, maleantes y maricas. Higiene, criminología y homosexualidad en la construcción de la Nación Argentina (Buenos Aires, 1871-1914), Buenos Aires: Beatriz Viterbo Editora.

- SAUTÚ, R. (2003) Todo es teoría. Objetivos y métodos de investigación, Buenos Aires: Editorial Lumiere.

- SAVENIJE, W. (2009) "Las pandillas callejeras o 'maras", Maras y barras. Violencia juvenil y pandillas en los barrios marginales de Centroamérica, San Salvador: FLACSO, pp. 95-159.

- SAXE, F. (2013) "Representación transnacional de las sexualidades disidentes en textos culturales alemanes y españoles recientes (1987-2012)". FAHCE-UNLP, tesis doctoral.

- SCHEPER-HUGHES, N. Y BOURGOIS, P. (eds.) (2005) "Introduction: making sense of violence", Violence in war and peace: an anthology, Oxford: Blackwell, pp. 131.

- SCOLARI, C. (2008) Hipermediaciones. Elementos para una Teoría de la Comunicación Digital Interactiva, Barcelona: Gedisa. 
- SEDGWICK, E. (1985) "Toward the Gothic: terrorism and homosexual panic", Between men: English literature and male homosocial desire, Nueva York: Columbia University Press.

- SEDGWICK, E. (1998) Epistemología del armario, Barcelona: L'Índex.

- SEDGWICK, E. (1999) "Performatividad queer. The art of the novel de Henry James", Nómadas, №10, abril, Bogotá: Universidad Central, pp. 198-214.

- SEDGWICK, E. (2002) “A(queer) y ahora”, en MÉRIDA JIMÉNEZ, R. (ed.) Sexualidades transgresoras. Una antología de estudios queer, Barcelona: Icaría, pp. 2954.

- SEGATO, R. (2010) Las estructuras elementales de la violencia. Ensayos sobre género entre la antropología, el psicoanálisis y los derechos humanos, Buenos Aires: Prometeo.

- SEMPOL, D. (2012) "La transición democrática uruguaya: caricaturas homofóbicas y movimientos homosexuales", en FORASTELLI, F. y OLIVERA, G. (coords.) Estudios queer. Semióticas y políticas de la sexualidad, Buenos Aires: La Crujía, pp. $88-98$.

- SETTANI, S. (2013) "Sexualidades politizadas y medios de comunicación: la Marcha del Orgullo LGBT en Buenos Aires", Revista AVATARES de la comunicación y la cultura, $\mathrm{N}^{\circ} 5$, Buenos Aires: UBA.

- SHELDON, J. (2010) “(Re)Searching queer subjects: approaching a queer methodology", ponencia presentada en el encuentro annual de American Educational Research Association, 7 de abril de 2010.

- SPARGO, T. (2004) Foucault y la teoría queer, Barcelona: Gedisa.

- STEVENSON, K. y BROADUS, K. (2016) Capturing hate: eyewitness videos provide new source of data on prevalence of transphobic violence, Nueva York: WITNESS. Disponible en https://library.witness.org/product/capturing-hate-report/ [Consultado el 8 de noviembre de 2016]

- TALBOT, M. (2003) "Gender stereotypes: reproduction and challenge", en HOLMES, J. y MEYERHOFF, M. (eds.) The Handbook of Language and Gender, Oxford: Blackwell Publishing.

- TAYLOR, C. (1993) El multiculturalismo y la "política del reconocimiento", México: Fondo de Cultura Económica. 
- THOMPSON, K. (2014) Pánicos morales, Bernal: Universidad Nacional de Quilmes Editorial.

- TONKONOFF, S. (2014) "Violencia, política y cultura. Una aproximación teórica", en BLANCO, A. y SÁNCHEZ, M. (coords.) Violencia y cultura: reflexiones contemporáneas sobre Argentina, Ciudad Autónoma de Buenos Aires: CLACSO, pp. 15-30.

- VAN DIJK, T. (1996) “Análisis del discurso ideológico”, Versión, № 6, México: UAM, pp. 15-43.

- VILAS, C. (2005) "Linchamientos: venganza, castigo e injusticia en escenarios de inseguridad”, Revista El Cotidiano, № 131, México, pp. 20-26.

- VITERI, M. A., SERRANO, J. F. y VIDAL-ORTIZ, S. (2011) “Cómo se piensa lo ‘queer' en América Latina?", Íconos. Revista de Ciencias Sociales, № 39, enero de 2011, Quito: FLACSO Ecuador, pp. 47-60. Disponible en https://www.flacso.edu.ec/ portal/files/docs/i39viteri.pdf [Consultado el 10 de enero de 2016]

- VV.AA. (2017) La Revolución de las Mariposas. A diez años de La Gesta del Nombre Propio, Buenos Aires: Ministerio Público de la Defensa de la Ciudad Autónoma de Buenos Aires.

- WEEKS, J. (2012) “Queer”, Lenguajes de la sexualidad, Buenos Aires: Nueva Visión, pp. 211-214.

- WHITE, P. (2004) "An introductory tour through appraisal theory", The appraisal website, Birmingham: University of Birmingham. Última actualización: 15 de junio de 2012. Recuperado de http://grammatics.com/appraisal/AppraisalOutline/UnFramed /AppraisalOutline.htm [Consultado el 23 de marzo de 2015].

- WILliAMS, R. (1976) "Violencia", Palabras clave. Un vocabulario de la cultura y la sociedad, Buenos Aires: Nueva Visión.

- WILLIAMS, R. (1982) "Las comunicaciones como ciencia cultural", en BIGSBY, C.W.E. (comp.) Examen de la cultura popular, México: Fondo de Cultura Económica.

- WILliAMS, R. (1997) La política del modernismo, Buenos Aires: Manantial.

- WILliAMS, R. (2000) "La hegemonía", Marxismo y literatura, Barcelona: Península, pp. 129-136.

- WITTIG, M. (1992) El pensamiento heterosexual y otros ensayos, Madrid: Egales. 
- WODAK, R. (2003a) "De qué trata el análisis crítico del discurso (ACD). Resumen de su historia, sus conceptos fundamentales y sus desarrollos", en WODAK, R. y MEYER, M. (comps.) Métodos de análisis crítico del discurso, Barcelona: Gedisa.

- WODAK, R. (2003b) "El enfoque histórico del discurso", en WODAK, R. y MEYER, M. (comps.) Métodos de análisis crítico del discurso, Barcelona: Gedisa.

- WRIGHT, S. (1998) "La politización de la 'cultura", en Anthropology Today № 1, vol. 14.

- YEP, G. (2003) "The violence of heteronormativity in communication studies: notes on injury, healing and queer world-making”, Journal of Homosexuality, Vol. 45, $\mathrm{N}^{\circ}$ 2/3/4, pp. 11-59.

- YUS, F. (2010) “Las redes sociales en Internet: la Web 2.0”, Ciberpragmática 2.0, Barcelona: Editorial Planeta, pp. 119-137.

- ŽIŽEK, S. (2009) Sobre la violencia: seis reflexiones marginales, Buenos Aires: Paidós.

\section{Enlaces a los posteos de los blogs:}

- Boquitas pintadas:

- DEMA, V. (19 de noviembre de 2013) “'Anita y sus dos mamás', un cuento infantil para pensar las familias diversas", Boquitas pintadas. Disponible en http://blogs.lanacion.com.ar/boquitas-pintadas/arte-y-cultura/anita-y-sus-dos-mamasun-cuento-infantil-para-pensar-las-familias-diversas/ [Consultado el 28 de enero de 2016]

- DEMA, V. (5 de diciembre de 2013) "Hay ley de matrimonio igualitario, pero ¿por qué casarse?", Boquitas pintadas. Disponible en http://blogs.lanacion.com.ar/boquitaspintadas/arte-y-cultura/hay-ley-de-matrimonio-igualitario-pero-por-que-casarse/ [Consultado el 28 de enero de 2016]

- DEMA, V. (9 de diciembre de 2013) "30 años de democracia y 10 conquistas de la comunidad gay y trans", Boquitas pintadas. Disponible en http://blogs.lanacion.com.ar/boquitas-pintadas/agenda/30-anos-de-democracia-y-10conquistas-de-la-comunidad-gay-y-trans/ [Consultado el 28 de enero de 2016] 
- DEMA, V. y VIEDMA, A. (13 de enero de 2014) “¿Todos y todas somos bisexuales?, Boquitas pintadas. Disponible en http://blogs.lanacion.com.ar/boquitaspintadas/discriminacion-y-homofobia/todos-y-todas-somos-bisexuales/ [Consultado el 28 de enero de 2016]

- DEMA, V. y ROMA (28 de enero de 2014) “"Era mi mejor amiga y nos saludábamos con un beso en la boca", Boquitas pintadas. Disponible en http://blogs.lanacion.com.ar/boquitas-pintadas/el-closet/era-mi-mejor-amiga-y-nossaludabamos-con-un-beso-en-la-boca/ [Consultado el 28 de enero de 2016]

- $\underline{T o d} @ s$ :

- BIMBI, B. (1 de enero de 2012) “El Papa pide perdón a los homosexuales”, Tod@s. Disponible en http://blogs.tn.com.ar/todxs/2012/01/01/el_papa_pide_perdon/ [Consultado el 28 de enero de 2016]

- BIMBI, B. (14 de enero de 2012) "El diputado y activista gay brasileño Jean Wyllys le responde al papa Benedicto XVI", Tod@s. Disponible en http://blogs.tn.com.ar/todxs/2012/01/14/el_diputado_y_activista_gay_brasileno_jean_w yllys_le_responde_al_papa_benedicto_xvi/[Consultado el 28 de enero de 2016] - BIMBI, B. (25 de marzo de 2012) “Daniel Zamudio”, Tod@s. Disponible en http://blogs.tn.com.ar/todxs/2012/03/25/daniel_zamudio/[Consultado el 28 de enero de 2016]

- BIMBI, B. (15 de febrero de 2013) "El Papa que huyó por amor (y se fue a vivir con su secretario)”, $\quad$ Tod@s. $\quad$ Disponible en http://blogs.tn.com.ar/todxs/2013/02/15/georg_e_joseph/ [Consultado el 28 de enero de 2016]

- BIMBI, B. (27 de noviembre de 2014) "Hablemos del subsidio para travestis y transexuales",Tod@s. Disponible en http://blogs.tn.com.ar/todxs/2014/11/27/subsidio/ [Consultado el 28 de enero de 2016]

Enlaces a los editoriales:

- La Nación: 
- S/A (14 de julio de 2013) "La Corte de los EE.UU. y el matrimonio igualitario", La Nación. Disponible en http://www.lanacion.com.ar/1600912-la-corte-de-los-eeuuy-elmatrimonio-igualitario [Consultado el 28 de enero de 2016]

- S/A (3 de marzo de 2014) "Uganda: la persecución a los homosexuales", La Nación. Disponible en http://www.lanacion.com.ar/1668847-uganda-la-persecucion-a-loshomosexuales [Consultado el 28 de enero de 2016]

- S/A (1 de noviembre de 2015) "Absurdo cupo para travestis y transexuales", La Nación. Disponible en http://www.lanacion.com.ar/1841726-absurdo-cupo-paratravestis-y-transexuales [Consultado el 28 de enero de 2016]

- Clarín:

- ROA, R. (30 de julio de 2013) "En lo cotidiano está la vida", Clarín. Disponible en http://www.clarin.com/opinion/cotidiano-vida_0_965303461.html [Consultado el 28 de enero de 2016]

- ROA, R. (10 de octubre de 2013) "Cambiar de sexo a los 6 años", Clarín. Disponible en http://www.clarin.com/opinion/Cambiar-sexo-anos_0_1008499161.html [Consultado el 28 de enero de 2016]

- S/A (27 de noviembre de 2014) "Travestis, cometas, Cristina y un juez", Clarín. Disponible en http://www.clarin.com/politica/Travestis-cometas-CristinaBonadio_0_1256274588.html [Consultado el 28 de enero de 2016]

$\underline{\text { Leyes, decretos y proyectos de ley: }}$

- DECRETO 267/2015 - Ente Nacional de Comunicaciones. Disponible en http://servicios.infoleg.gob.ar/infolegInternet/anexos/255000259999/257461/norma.htm [Consultado el 13 de noviembre de 2016]

- EXPEDIENTE 10-PE-2017 - Proyecto de Ley de Libertad Religiosa. Disponible en http://www4.hcdn.gob.ar/dependencias/dsecretaria/Periodo2017/PDF2017/TP2017/001 0-PE-2017.pdf [Consultado el 1 de julio de 2017]

- EXPEDIENTE 1552-S-16 - Proyecto de Ley: Prevención y sanción de actos discriminatorios, modificaciones al Código Penal y abrogación de la ley 23.592 y sus modificatorias. Disponible en http:/www.mariarachid.com.ar/wp- 
content/uploads/2016/06/Proyecto-Abal-Medina-Kunath-S1552-16PL-1.pdf

[Consultado el 30 de octubre de 2016]

- EXPEDIENTE 1865-S-15 - Proyecto de Ley regulando a los Proveedores de Servicios de Enlace y Búsqueda de Contenidos alojados en Internet. Disponible en http://www.senado.gov.ar/parlamentario/parlamentaria/verExp/parla/S-1865.15-PL

[Consultado el 1 de julio de 2017]

- EXPEDIENTE 4447-D-2016 - Proyecto de Ley Nacional contra la Discriminación: http://www1.hcdn.gov.ar/proyxml/expediente.asp?fundamentos=si\&numexp=4447-D-

2016 [Consultado el 30 de octubre de 2016]

- EXPEDIENTE 4725-S-16 - Proyecto de Ley: modificación de la ley 26.485 de Protección integral a las mujeres. Disponible en www.senado.gov.ar/parlamentario/parlamentaria/384310/downloadPdf [Consultado el 10 de marzo de 2017]

- EXPEDIENTE 7379-D-14 - Proyecto de Ley: Actos Discriminatorios e instrumentos de Derechos Humanos, promoción de la no discriminación en Internet. Disponible en http://www1.hcdn.gov.ar/proyxml/expediente.asp?fundamentos=si\&numexp=7379-D2014 [Consultado el 30 de octubre de 2016]

- EXPEDIENTE 9064-D-14 - Proyecto de Ley contra la Discriminación. Disponible en http://www1.hcdn.gov.ar/proyxml/expediente.asp? fundamentos=si\&numexp=9064D-2014 [Consultado el 27 de marzo de 2016]

- EXPEDIENTE 942-S-16 - Proyecto de Ley sobre Responsabilidades de los Proveedores de Internet. Disponible en http://www.senado.gov.ar/parlamentario/parlamentaria/verExp/parla/S-942.16-PL

[Consultado el 1 de julio de 2017]

- LEY 11.179, actualizada en 1984 - Código Penal de la Nación Argentina. Disponible en http://www.informaticalegal.com.ar/1984/05/01/codigo-penal-de-la-nacionargentina/ [Consultado el 27 de marzo de 2016]

- LEY 19.798/1972 - Ley Nacional de Telecomunicaciones. Disponible en http://servicios.infoleg.gob.ar/infolegInternet/anexos/30000-34999/31922/texact.htm [Consultado el 13 de noviembre de 2016]

- LEY 22.285/1980 - Ley Nacional de Radiodifusión. Disponible en http://servicios.infoleg.gob.ar/infolegInternet/anexos/15000-19999/17694/texact.htm [Consultado el 13 de noviembre de 2016] 
- LEY 23.592/1988 - Actos Discriminatorios. Disponible en http://www.infoleg.gov.ar/infolegInternet/anexos/20000-24999/20465/texact.htm [Consultado el 27 de marzo de 2016]

- LEY 24.430/1994 - Constitución Nacional de la República Argentina. Disponible en http://infoleg.mecon.gov.ar/infolegInternet/anexos/0-4999/804/norma.htm [Consultado el 27 de marzo de 2016]

- LEY 26.388/2008 - Delitos Informáticos. Disponible en http://www.infoleg.gob.ar/infolegInternet/anexos/140000-144999/141790/norma.htm [Consultado el 27 de marzo de 2016]

- LEY 26.522/2009 - Ley Nacional Servicios de Comunicación Audiovisual. Disponible en http://servicios.infoleg.gob.ar/infolegInternet/anexos/155000159999/158649/norma.htm [Consultado el 13 de noviembre de 2016]

- LEY 26.551/2009 - Modificación del Código Penal. Disponible en http://servicios.infoleg.gob.ar/infolegInternet/anexos/160000164999/160774/norma.htm [Consultado el 30 de octubre de 2016]

- LEY 26.994/2014 - Código Civil y Comercial. Disponible en http://www.infoleg.gob.ar/infolegInternet/anexos/235000-239999/235975/norma.htm [Consultado el 27 de marzo de 2016]

- LEY 27.078/2014 - Ley Argentina Digital. Disponible en http://servicios.infoleg.gob.ar/infolegInternet/anexos/235000239999/239771/norma.htm [Consultado el 13 de noviembre de 2016]

- LEY CABA 1.472/2004 - Código Contravencional. Disponible en http://www.informaticalegal.com.ar/2004/09/23/codigo-contravencional-de-la-ciudadautonoma-de-buenos-aires/ [Consultado el 27 de marzo de 2016]

- LEY CABA 5.261/2015 - Contra la Discriminación. Disponible en http://www.legis.com.ar/BancoConocimiento/N/noticias_06102015_ley_caba_5261/not icias_06102015_ley_caba_5261.asp?Miga=1\&CodSeccion=25 [Consultado el 27 de marzo de 2016]

- LEY PBA 14.783/2015 - Ley de cupo laboral trans. Disponible en http://www.gob.gba.gov.ar/legislacion/legislacion/l-14783.html [Consultado el 13 de noviembre de 2016] 
Fuentes periodísticas:

- AGUER, H. (23 de agosto de 2016) "La fornicación”, El Día. Disponible en http://www.eldia.com/opinion/la-fornicacion-159535 [Consultado el 28 de noviembre de 2016]

- AGUER, H. (4 de octubre de 2016) “¿Es justo todo lo legal? La injusticia de un Decreto", El Día. Disponible en http://www.eldia.com/opinion/es-justo-todo-lo-legal-lainjusticia-de-un-decreto-169893 [Consultado el 28 de noviembre de 2016]

- BORRILlO, D. (2016) "Los nuevos rostros de la homofobia", Página/12, 13 de mayo de 2016. Disponible en http://www.pagina12.com.ar/diario/suplementos/soy/14532-2016-05-13.html [Consultado el 20 de julio de 2016]

- BUSANICHE, B. (2015) "Proyecto de Ley Antidiscriminación: una supuesta solución que amplia los problemas", Fundación Vía Libre. Disponible en http://www.vialibre.org.ar/wp-content/uploads/2015/07/discriminacion.pdf [Consultado el 20 de marzo de 2016]

- CORRADINI, L. (23 de mayo 2017) “Al descubierto: revelan las reglas de Facebook sobre sexo y violencia", La Nación. Disponible en http://www.lanacion.com.ar/2026451-al-descubierto-revelan-las-reglas-de-facebooksobre-sexo-y-violencia [Consultado el 26 de mayo 2017]

- COX, J. (22 de noviembre de 2016) "The FBI Hacked Over 8,000 Computers In 120 Countries Based on One Warrant", Motherboard. Disponible en https://motherboard.vice.com/read/fbi-hacked-over-8000-computers-in-120-countriesbased-on-one-warrant [Consultado el 26 de noviembre de 2016]

- ESPAÑA, P. (7 de octubre de 2016) "Nunca más", Página/12. Disponible en http://www.pagina12.com.ar/diario/suplementos/soy/1-4782-2016-10-08.html

[Consultado el 22 de octubre de 2016]

- GONZÁLEZ, P. A. (27 de diciembre de 2016) “Jugada preparada”, El gato y la caja. Disponible en https://elgatoylacaja.com.ar/jugada-preparada/ [Consultado el 1 de enero de 2017]

- PAULÓN, E. (17 de julio de 2017) "Restringir derechos en nombre de la libertad", InfoBae. Disponible en https:/www.infobae.com/opinion/2017/07/17/restringirderechos-en-nombre-de-la-libertad/ [Consultado el 20 de julio de 2017] 
- PECHENY, M. (2015) “Dinosaurios vivos”, Página/12, Suplemento Soy, 10 de julio de 2015. Disponible en http://www.pagina12.com.ar/diario/suplementos/soy/1-40762015-07-11.html [Consultado el 23 de enero de 2016]

- S/A (2011) "Number of blogs worldwide from 2006 to 2011 (in millions)", Statista, the statistics portal. Disponible en http://www.statista.com/statistics/278527/number-ofblogs-worldwide [Consultado el 1 de febrero de 2016]

- S/A (21 de diciembre de 2016) 'Las 20 peores 'investigaciones científicas' del Conicet, La Internet Online. Disponible en https://www.lainternetonline.com/ultimomomento/las-20-peores-investigaciones-cientificas-del-conicet/ [Consultado el 1 de enero de 2017].

- S/A (26 de noviembre de 2014) "Piden subsidios de \$8.000 para travestis", Clarín. Disponible en http://www.clarin.com/ciudades/travestis-subidio-rachidconti_0_r1X8QpvcPQe.html [Consultado el 10 de marzo de 2017]

- S/A (5 de noviembre de 2009) "Matrimonio y heterosexualidad", La Nación. Disponible en http://www.lanacion.com.ar/1194770-matrimonio-y-heterosexualidad [Consultado el 27 de enero de 2016] 